\title{
Obesity treatment : evaluation of conservative treatment strategies
}

Citation for published version (APA):

Erik Aller, E. (2015). Obesity treatment : evaluation of conservative treatment strategies. [Doctoral Thesis, Maastricht University]. Datawyse / Universitaire Pers Maastricht. https://doi.org/10.26481/dis.20151119ee

Document status and date:

Published: 01/01/2015

DOI:

10.26481/dis.20151119ee

Document Version:

Publisher's PDF, also known as Version of record

\section{Please check the document version of this publication:}

- A submitted manuscript is the version of the article upon submission and before peer-review. There can be important differences between the submitted version and the official published version of record.

People interested in the research are advised to contact the author for the final version of the publication, or visit the DOI to the publisher's website.

- The final author version and the galley proof are versions of the publication after peer review.

- The final published version features the final layout of the paper including the volume, issue and page numbers.

Link to publication

\footnotetext{
General rights rights.

- You may freely distribute the URL identifying the publication in the public portal. please follow below link for the End User Agreement:

www.umlib.nl/taverne-license

Take down policy

If you believe that this document breaches copyright please contact us at:

repository@maastrichtuniversity.nl

providing details and we will investigate your claim.
}

Copyright and moral rights for the publications made accessible in the public portal are retained by the authors and/or other copyright owners and it is a condition of accessing publications that users recognise and abide by the legal requirements associated with these

- Users may download and print one copy of any publication from the public portal for the purpose of private study or research.

- You may not further distribute the material or use it for any profit-making activity or commercial gain

If the publication is distributed under the terms of Article $25 \mathrm{fa}$ of the Dutch Copyright Act, indicated by the "Taverne" license above, 


\section{OBESITY TREATMENT}

Evaluation of conservative treatment strategies

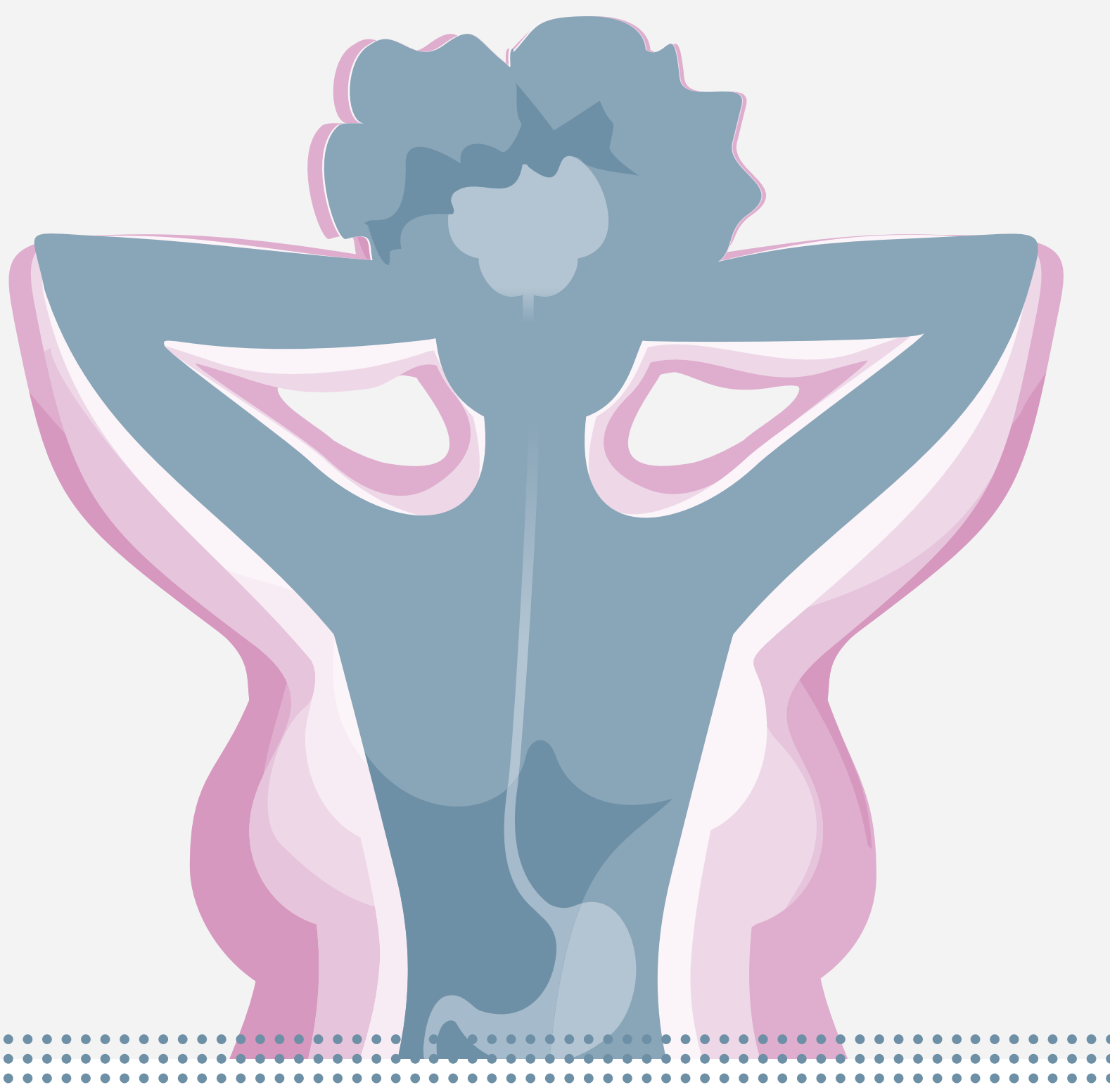

Erik Aller 

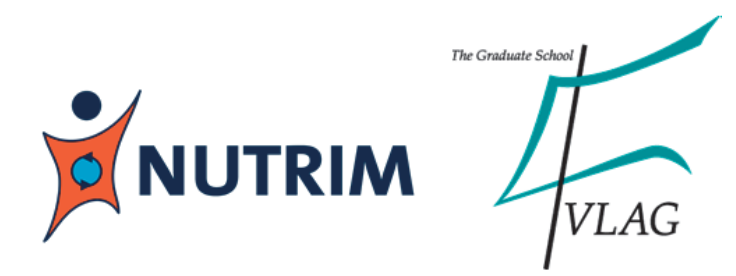

The research presented in this thesis was performed within NUTRIM School of Nutrition and Translational Research in Metabolism which participates in the Graduate School VLAG (Food, Technology, Agrobiotechnology, Nutrition and Health Sciences), accredited by the Royal Netherlands Academy of Arts and Sciences.

Financial support from Zorg van de Zaak and the Netherlands Association for the Study of Obesity (NASO) for the publication of this thesis is gratefully acknowledged.

\section{ZorgvandeZaak}

(C) Erik Aller, Maastricht 2015

Cover design: Patriek Pelzers

Layout: $\quad$ Erik Aller

Printing: Datawyse | Universitaire Pers Maastricht

ISBN 9789461594709

Copyright: Erik Aller 


\title{
Obesity Treatment \\ Evaluation of conservative treatment strategies
}

\author{
PROEFSCHRIFT
}

ter verkrijging van de graad van doctor aan de Universiteit Maastricht, op gezag van de Rector Magnificus, Prof. dr. L.L.G. Soete,

volgens het besluit van het College der Decanen,

in het openbaar te verdedigen

op donderdag 19 november 2015 om 10:00h

door

\section{Erik Everdina Johannes Gemma Aller}

Geboren op 24 december 1982 te Sittard, Nederland

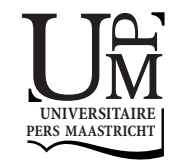




\section{Promotores}

Prof. dr. M.A. van Baak

Prof. dr. H. Kuipers

\section{Beoordelingscommissie}

Prof. dr. E. Blaak (voorzitter)

Prof. dr. L. Mathus-Vliegen

Prof. dr. F. Nijhuis

Dr. T. Visscher

Prof. dr. M. Westerterp-Plantenga 


\section{CONTENTS}

$\begin{array}{lll}\text { Chapter } 1 \text { General introduction } & 7\end{array}$

$\begin{array}{lll}\text { Chapter } 2 \text { Starches, sugars and obesity } & 19\end{array}$

Chapter 3 Weight loss maintenance in overweight subjects on ad libitum 51 diets with high or low protein content and glycemic index: the DIOGENES trial 12 months results

Chapter 4 Evaluation of an 18 months commercial multidisciplinary obesity treatment programme

Chapter 5 Physical activity improves glucose tolerance independent of 101 weight loss in severe obesity

Chapter 6 Genetic predictors for high weight loss by multidisciplinary advice to severely obese subjects in real-life circumstances

Chapter 7 General Discussion

Summary

Samenvatting

Valorization

Dankwoord 155

Curriculum vitae

List of publications 

CHAPTER 1

General introduction 


\section{Obesity}

Obesity is defined as an excessive accumulation of fat that presents a risk to health (1). Overweight and obesity are associated with numerous co-morbid conditions like type 2 diabetes mellitus, hypertension, cardiovascular disease and certain forms of cancer (2). Mental health conditions and reduced mental well being are often seen in obese individuals $(3,4)$. Overweight and obesity used to only be a problem in high income countries, but are now on the rise in low and middle income countries, especially in densely populated areas. (5-7).

Body mass index (BMI) is a simple calculation of weight-for-height that is commonly used in classifying overweight and obesity in adult populations and individuals. It is defined as weight in kilograms divided by the square of height in meters $\left(\mathrm{kg} / \mathrm{m}^{2}\right)$. A BMI $\geq 25 \mathrm{~kg} / \mathrm{m}^{2}$ is referred to as overweight and a BMI $\geq 30 \mathrm{~kg} / \mathrm{m}^{2}$ indicates obesity (1).

The prevalence of overweight and obese persons in the Dutch population is alarming. From 1981 to 2004 the prevalence of obesity, based on measured body mass index, in the Dutch population had almost doubled, reaching $10 \%$ for men and $13 \%$ for women in 2004 (8). In 2011 according to self-reported data, approximately half of the Dutch population (54\% of men and $43 \%$ of women) was overweight or obese (9).

\section{A brief history of obesity}

We now know that obesity is associated with numerous unfavourable health consequences (2). But for centuries, corpulence had a much more positive connotation than it has now. Art objects made by Michelangelo (1475-1564) and Rubens (1577-1643) show full and rounded women. Until the early 1900's associations with affluence, power and influence, can be seen in the paintings of industrial barons and feminine figures by Auguste Renoir (1841-1919). Even some former presidents of the USA (Hoover, Taylor, Grant, Taft and Cleveland) underline this association of obesity with prosperity, health and strength. The medical literature starts to mention the health consequences of obesity in the eighteenth century (10). William Cullen (1710-1790) reported gout, fatigue and breathing difficulties. But it wasn't until the 1920's that excess weight was associated with increased mortality (11). By the 1960's the study of obesity began to flourish and body fat was no longer regarded as a passive energy store but was seen as an organ with its own hormones, receptors and cellular biology (12).

\section{Risk factors for weight gain}

Since the association of excess weight with increased mortality, there has been an ongoing search for the cause of the increasing epidemic of overweight and obesity. Endo- 
crine causes of obesity are identified in less than 1 percent of children and adolescents with obesity (13). The disorders that cause obesity in these persons include hypothyroidism, cortisol excess, growth hormone deficiency, and acquired hypothalamic lesions (14).

Physical activity and diet seem to be the most important actors in the obesity epidemic in the general population (15). Weight gain and obesity in free living populations results from a long-term positive energy balance, where energy intake exceeds energy expenditure (16). The 'obesogenic' environment that we are exposed to, makes it easy to consume a lot of calorie dense food and to reduce energy expenditure to a minimum (17). Research shows that the basis for an unhealthy lifestyle is already laid at a young age, where television viewing, leisure time inactivity and an unhealthy diet are already linked (18). When this basis is not adequately changed over the course of childhood or adolescence, then obesity in adulthood is very likely (19).

There is also growing evidence that psychological problems play an important role in the development and maintenance of obesity (4). Binge eating disorder or disturbed eating habits are quite common among people who suffer from obesity. Prevalence rates vary widely from $1 \%$ to $30 \%$ in patients seeking non-surgical weight loss treatment $(20)$ and $2 \%$ to $49 \%$ in bariatric surgery candidates $(21,22)$.

Genetic predisposition is currently a widely studied topic in obesity research. Results from family studies suggest that the maximum heritability of obesity phenotypes ranges from about $30 \%$ to $50 \%$ (23). Extensive research has identified several genes that have shown associations with obesity related phenotypes (24) and that may be involved in various processes ranging from regulation of eating behaviour (e.g. FTO, LEP and MC4R (25)), to preadipocyte differentiation and fat storage (e.g. PPARG and PLIN) (26-29). Such genetic predisposition might also play a role when people are trying to lose weight (30).

\section{Co-morbidities of obesity}

Co-morbidities are very common in obesity and include abnormalities in the endocrine, cardiovascular, gastrointestinal, pulmonary, orthopedic, neurologic, dermatologic, and psychosocial systems. Particularly, abdominal obesity is associated with resistance to the effects of insulin on peripheral glucose and fatty acid utilization, often leading to type 2 diabetes mellitus (31). Insulin resistance, associated hyperinsulinemia and hyperglycemia, and also adipocyte-secreted factors (adipokines) may also lead to vascular endothelial dysfunction, an abnormal lipid profile, hypertension, and vascular inflammation, all of which promote the development of atherosclerotic cardiovascular disease (CVD) (32-35). A similar profile can be seen in individuals with abdominal obesity without an excess of total body weight (36-39). The co-occurrence of metabolic risk factors for both type 2 diabetes and CVD (abdominal obesity, hyperglycemia, 
dyslipidemia, low grade inflammation, and hypertension) suggested the existence of a "metabolic syndrome" (35, 40-42). Several factors associated with co-morbid conditions in obesity and relevant to this thesis will be discussed presently.

\section{Impaired glucose tolerance}

Impaired glucose tolerance (IGT) which predicts the development of diabetes, is a common complication of childhood and adolescent obesity $(43,44)$. About $85 \%$ of all patients who have type 2 diabetes mellitus are also obese (45). Early recognition of IGT in obese persons is therefore essential for preventing type 2 diabetes.

\section{Hyperlipidemia}

Hyperlipidemia is a major risk factor for cardiovascular disease $(32,34)$. An increase in $\mathrm{BMI}$ is associated with an increase in the occurrence of hyperlipidemia among adults $(46,47)$. The typical pattern is one of an elevated concentration of serum low density lipoprotein (LDL) cholesterol and triglycerides and a decreased concentration of high density lipoprotein (HDL) cholesterol (47). Best predictors of future cardiovascular events seem to be the total cholesterol/HDL ratio and the LDL/HDL ratio (48). Research suggests to rather choose the total cholesterol/HDL ratio than the LDL/HDL ratio because the triglyceride level (included in in the total cholesterol calculation)/HDL ratio but not in the LDL/HDL ratio) is an independent predictor of coronary heart disease and death from such among women (49).

\section{Waist-circumference}

Waist circumference or waist-to-hip ratio, are useful ways of assessing fat distribution. Increased values of waist circumference (men $>102 \mathrm{~cm}$; women $>88 \mathrm{~cm}$ ) or waist-to-hip ratio (men $>0.95$; women $>0.8$ ) confer additional cardiovascular risk (50). Abdominal obesity in particular increases the risk of CVD and type 2 diabetes because of impairments in lipid metabolism, an increase in inflammatory markers as well as the occurrence of a pro-thrombotic state (51) and hypertension (52).

\section{Hypertension}

The risk of hypertension is increased in overweight and obese subjects. In a large crosssectional survey of US men and women, the prevalence of hypertension increased from 
$18 \%$ for normal weight to $52 \%$ for obese (BMI $35-39.9 \mathrm{~kg} / \mathrm{m}^{2}$ ) persons (46). Poirier et al. (52) found a significant correlation between abdominal obesity and hypertension in non-obese men. Several mechanisms may contribute to an increase in blood pressure resulting from increasing levels of abdominal adiposity in a manner independent of insulin resistance.

Sympathetic activation associated with obesity and molecules released by hypertrophied fat cells, are factors that may promote the formation of angiotensin II (Ang II) and aldosterone, which have direct vasopressor and antinatriuretic effects. A local renin-angiotensinogen system (RAS) has been found to be present in human adipose tissue and may act as a distinct system from the plasma RAS. Indeed, all components of the RAS system: angiotensinogen [AGT], Ang II type 1 [AT1] receptor, and angiotensinconverting enzyme but not renin and AT2 receptor, are found in adipose tissue (52). Fasting insulin may be related to hypertension by being a crude marker of the metabolic abnormalities associated with insulin resistance. However, results of the study by Poirier et al. (52) suggests that WC may be a better marker of a cluster of blood pressure raising abnormalities than fasting insulin.

\section{Treatment strategies}

The optimal management of overweight and obesity starts with a combination of diet, exercise, and behavioral modification. In addition, some patients eventually require pharmacologic therapy or bariatric surgery.

\section{Dietary treatment}

Most dietary weight loss strategies lead to reasonable weight loss at 6 months (i.e. loss of $5-10 \%$ of initial body weight). Caloric restriction, rather than macronutrient composition seems to be the key determinant of diet based weight loss (53). With that weight loss, these diets also show improvements in cardiometabolic risk factors (54). It should be taken in consideration that some macronutrient compositions might be more favourable over others depending on possible co-morbid conditions like diabetes or hyperlipidemia (55). In a recent large meta-analysis, the authors concluded that every diet works if adhered to (56). In the case of weight maintenance after weight loss, high protein diets seem to produce the best results (54). These data show that weight loss solely by dietary intervention can have a positive effect on metabolic risk factors. 


\section{Physical activity}

Increasing physical activity alone without a dietary intervention is hardly effective in treating obesity, but exercise in combination with diet produces a moderately greater weight loss than diet alone $(57,58)$. It also has many health benefits that are weight loss independent. For example, it has been shown to improve the incidence of type 2 diabetes mellitus (59), lower levels of blood pressure, lipids and glycaemia (60-62), reduction in cardiovascular disease (63) particularly heart disease, and in mortality (64). Improvements in biliary disease, respiratory capacity, cancer, and in psychological parameters such as anxiety, depression and stress have also been reported (65). In the 2013 guideline for managing overweight and obesity the authors note that they typically prescribe increasing aerobic physical activity (such as brisk walking) to more than 150 $\mathrm{min} /$ week (equal to $>30 \mathrm{~min} /$ day most days of the week). The strategy starts with low levels (10 $\mathrm{min} /$ day) and gradually increases to the goal (66).

\section{Behavioural modification}

Behaviour therapy is a useful addition to planned adjustments in food intake and physical activity. Specific behavioural strategies include: self-monitoring, stress management, stimulus control, problem solving, contingency management and cognitive restructuring. Behavioural therapies may be employed to promote adoption of diet and activity adjustments; these will be useful for a combined approach (67). Cognitive behavioural therapy (CBT) is a potent therapy when treating disordered eating. It can improve restrained eating and reduce disinhibition (68), two traits that are often seen in obese patients (69). Enhancing social support may also be a means for improving long-term weight loss (70). Inclusion of family members or spouses is one of the best ways to accomplish this. There are both short-term and long-term benefits to programs that include strong family support. In a meta-analysis of four 12 month behavioural programs that included family members, mean weight loss in the family based intervention was approximately $3 \mathrm{~kg}$ more than in the control behavioural programs (71).

\section{Drug therapy}

Drug therapy may be effective if given without lifestyle modification $(72,73)$ but is most effective when combined with diet, increased physical activity, and behaviour modification (73). Therefore, weight loss drugs should only be used as part of a comprehensive weight loss regimen (74). In the Netherlands there is only one weight loss drug legally available: orlistat. 
Orlistat (brand name: XenicalC) is a lipase inhibitor (75), which acts by partially inhibiting the hydrolysis of triglycerides into absorbable free fatty acids and monoacylglycerols and thereby reduces caloric intake by inhibiting the absorption of dietary fats in the intestinal lumen by around 30\% (76). The major adverse effects with orlistat are gastrointestinal. Fatty and oily stool, faecal urgency, and oily spotting occurred in $15-30 \%$ of orlistat treated patients (2-7\% with placebo) (77).

Recently, the European Medicines Agency has recommended bupropion/naltrexone (78) and liraglutide (79) for approval in weight management in adults. It is expected that these two drugs will be available on the European market in 2015.

\section{Surgery}

The goal of bariatric surgery is to reduce the morbidity and mortality associated with obesity and to improve metabolic and organ function. Several studies have demonstrated that bariatric surgery is effective in reducing obesity related comorbidities (80, 81). There are currently several weight loss surgery procedures available to treat obesity. Bariatric surgery has two primary approaches to achieve weight loss, and treatment typically emphasizes either the restrictive or mal-absorptive approach or a combination of the two (hybrid surgery).

Restrictive approaches limit the amount of food consumed by reducing the size of the stomach, whereas hybrid approaches limit the absorption of nutrients by bypassing parts of the intestine in addition to the stomach restriction (82). It should be mentioned that bariatric surgery is usually only performed in the case of morbid obesity (BMI > 40 $\mathrm{kg} / \mathrm{m}^{2}$ ) when other weight loss methods did not succeed.

\section{Outline of the thesis}

This thesis starts with a review on the effects of different starches and sugars on body weight management and metabolic disturbances in chapter 2 , with a clear focus on obesity and its metabolic co-morbidities. In chapter $\mathbf{3}$ we reported the 12 month results in two of the study centers involved in the DIOGENES trial, Maastricht and Copenhagen. The DIOGENES dietary intervention study was initiated to study the role of dietary protein content and $\mathrm{GI}$ in the prevention of weight regain after weight loss. In chapter 4 we evaluated the 18 month CO-EUR treatment programme and reported on treatment results for weight, cardiometabolic risk factors, eating behaviour and quality of life. In chapter $\mathbf{5}$ we explored the independent contributions of changes in weight, physical activity, sleep efficiency and excessive daytime sleepiness, to changes in glucose tolerance in obese subjects during treatment in the CO-EUR programme. In chapter 6 we searched for genetic predictors of high weight loss in an obese population that partici- 
pated in the CO-EUR treatment programme. In chapter 7, the main findings of this thesis are discussed and are put into a broader perspective.

\section{References}

1. WHO. Factsheet no. 311: overweight and obesity 2015 [cited 2015 march 27]. Available from: http://www.who.int/mediacentre/factsheets/fs311/en/.

2. Skolnik NS, Ryan DH. Pathophysiology, epidemiology, and assessment of obesity in adults. The Journal of family practice. 2014;63(7):S3-S10.

3. Ul-Haq Z, Mackay DF, Fenwick E, Pell JP. Impact of metabolic comorbidity on the association between body mass index and health-related quality of life: a Scotland-wide cross-sectional study of 5,608 participants. BMC public health. 2012;12:143.

4. Williamson DA, Martin CK, Stewart T. Psychological aspects of eating disorders. Best practice \& research Clinical gastroenterology. 2004;18(6):1073-88.

5. Lee YS, So JB, Deurenberg Yap M. Confronting the obesity epidemic: call to arms. Ann Acad Med Singapore. 2009;38(1):1-2.

6. Low S, Chin MC, Deurenberg Yap M. Review on epidemic of obesity. Ann Acad Med Singapore. 2009;38(1):57-9.

7. WorldHealthOrganisation. Factsheet: obesity and overweight 2006 [cited 2009 february 24th]. Available from: http://www.who.int/mediacentre/factsheets/fs311/en/index.html.

8. Schokker DF, Visscher TL, Nooyens AC, van Baak MA, Seidell JC. Prevalence of overweight and obesity in the Netherlands. Obesity reviews : an official journal of the International Association for the Study of Obesity. 2007;8(2):101-8.

9. CBS. Cijfers overgewicht en obesitas 2011 [cited 2015 march 27]. Available from: http://www.cbs.nl/nl$\mathrm{NL} / \mathrm{menu} /$ themas/gezondheid-welzijn/publicaties/artikelen/archief/2012/2012-3746-wm.htm.

10. Guerrini A. Obesity and depression in the enlightenment : the life and times of George Cheyne. Norman, OK: University of Oklahoma Press; 2000. xx, 283 p. p.

11. Dublin LI, Lotka AJ, Metropolitan Life Insurance Company. Statistical Bureau., Metropolitan Life Insurance Company. Twenty-five years of health progress; a study of the mortality experience among the industrial policyholders of the Metropolitan Life Insurance Company 1911 to 1935. New York, San Francisco etc.: Metropolitan Life Insurance Company; 1937. xi, 611 p. incl. illus. (maps) tables, diagrs. p.

12. Wood PA. How fat works. Cambridge, Mass.: Harvard University Press; 2006. xii, 249 p. p.

13. Reinehr T, Hinney A, de Sousa G, Austrup F, Hebebrand J, Andler W. Definable somatic disorders in overweight children and adolescents. J Pediatr. 2007;150(6):618-22, 22.e1-5.

14. Speiser PW, Rudolf MC, Anhalt H, Camacho Hubner C, Chiarelli F, Eliakim A, et al. Childhood obesity. J Clin Endocrinol Metab. 2005;90(3):1871-87.

15. Redinger RN. The prevalence and etiology of nongenetic obesity and associated disorders. South Med J. 2008;101(4):395-9.

16. Sinha A, Kling S. A review of adolescent obesity: prevalence, etiology, and treatment. Obes Surg. 2009;19(1):113-20.

17. Kirk SF, Penney TL, McHugh TL. Characterizing the obesogenic environment: the state of the evidence with directions for future research. Obesity reviews : an official journal of the International Association for the Study of Obesity. 2010;11(2):109-17.

18. Ludwig DS, Gortmaker SL. Programming obesity in childhood. Lancet. 2004;364(9430):226-7.

19. Lobstein T, Jackson-Leach R, Moodie ML, Hall KD, Gortmaker SL, Swinburn BA, et al. Child and adolescent obesity: part of a bigger picture. Lancet. 2015.

20. Dingemans $A E$, Bruna MJ, van Furth EF. Binge eating disorder: a review. International journal of obesity and related metabolic disorders : journal of the International Association for the Study of Obesity. 2002;26(3):299-307. 
21. Mitchell JE, Lancaster KL, Burgard MA, Howell LM, Krahn DD, Crosby RD, et al. Long-term follow-up of patients' status after gastric bypass. Obes Surg. 2001;11(4):464-8.

22. Burgmer R, Grigutsch K, Zipfel S, Wolf AM, de Zwaan M, Husemann B, et al. The influence of eating behavior and eating pathology on weight loss after gastric restriction operations. Obes Surg. 2005;15(5):684-91.

23. Perusse L, Bouchard C. Role of genetic factors in childhood obesity and in susceptibility to dietary variations. Ann Med. 1999;31 Suppl 1:19-25.

24. Rankinen T, Zuberi A, Chagnon YC, Weisnagel SJ, Argyropoulos G, Walts B, et al. The human obesity gene map: the 2005 update. Obesity (Silver Spring). 2006;14(4):529-644.

25. Speliotes EK, Willer CJ, Berndt SI, Monda KL, Thorleifsson G, Jackson AU, et al. Association analyses of 249,796 individuals reveal 18 new loci associated with body mass index. Nature genetics. 2010;42(11):937-48.

26. Erez G, Tirosh A, Rudich A, Meiner V, Schwarzfuchs D, Sharon N, et al. Phenotypic and genetic variation in leptin as determinants of weight regain. International journal of obesity. 2011;35(6):785-92.

27. Soenen S, Mariman EC, Vogels N, Bouwman FG, den Hoed M, Brown L, et al. Relationship between perilipin gene polymorphisms and body weight and body composition during weight loss and weight maintenance. Physiology \& behavior. 2009;96(4-5):723-8.

28. Vogels N, Mariman EC, Bouwman FG, Kester AD, Diepvens K, Westerterp-Plantenga MS. Relation of weight maintenance and dietary restraint to peroxisome proliferator-activated receptor gamma2, glucocorticoid receptor, and ciliary neurotrophic factor polymorphisms. The American journal of clinical nutrition. 2005;82(4):740-6.

29. Delahanty LM, Pan Q, Jablonski KA, Watson KE, McCaffery JM, Shuldiner A, et al. Genetic predictors of weight loss and weight regain after intensive lifestyle modification, metformin treatment, or standard care in the Diabetes Prevention Program. Diabetes care. 2012;35(2):363-6.

30. Teixeira PJ, Going SB, Sardinha LB, Lohman TG. A review of psychosocial pre-treatment predictors of weight control. Obesity reviews : an official journal of the International Association for the Study of Obesity. 2005;6(1):43-65.

31. Goossens $\mathrm{GH}$. The role of adipose tissue dysfunction in the pathogenesis of obesity-related insulin resistance. Physiology \& behavior. 2008;94(2):206-18.

32. DeFronzo R, Ferrannini E. Insulin resistance. A multifaceted syndrome responsible for NIDDM, obesity, hypertension, dyslipidemia, and atherosclerotic cardiovascular disease. Diabetes care. 1991;14(3):17394.

33. Koh K, Han S, Quon M. Inflammatory markers and the metabolic syndrome insights from therapeutic interventions. Journal of the American College of Cardiology. 2005;46(11):1978-85.

34. Lindsay R, Howard B. Cardiovascular risk associated with the metabolic syndrome. Current Diabetes Reports. 2004;4(1):63-8.

35. Reaven G. Banting lecture 1988. Role of insulin resistance in human disease Diabetes. 1988;37(12):1595607.

36. Conus F, Allison D, Rabasa-Lhoret R, St-Onge M, St-Pierre D, Tremblay-Lebeau A, et al. Metabolic and behavioral characteristics of metabolically obese but normal-weight women. Journal of Clinical Endocrinology \& Metabolism. 2004;89(10):5013-20.

37. Richelsen B, Pedersen S. Associations between different anthropometric measurements of fatness and metabolic risk parameters in non-obese, healthy, middle-aged men. International Journal of Obesity and Related Disorders. 1995;19(3):169-74.

38. Ruderman N, Chisholm D, Pi-Sunyer X, Schneider S. The metabolically obese, normal-weight individual revisited. Diabetes. 1998;47(5):699-713.

39. St-Onge M, Janssen I, Heymsfield S. Metabolic syndrome in normal-weight Americans: new definition of the metabolically obese, normal-weight individual. Diabetes care. 2004;27(9):2222-8.

40. Eckel R, Grundy S, Zimmet P. The metabolic syndrome. Lancet. 2005;365(9468):1415-28.

41. Ferrannini E, Haffner S, Mitchell B, Stern M. Hyperinsulinaemia: the key feature of a cardiovascular and metabolic syndrome. Diabetologia. 1991;34(6):416-22. 
42. Haffner S, Valdez R, Hazuda H, Mitchell B, Morales P, Stern M. Prospective analysis of the insulinresistance syndrome (syndrome X). Diabetes. 1992;41(6):715-22.

43. Sainaghi PP, Castello L, Bergamasco L, Carnevale Schianca GP, Bartoli E. Metabolic characteristics of glucose intolerance: the critical role of obesity. Exp Clin Endocrinol Diabetes. 2008;116(2):86-93.

44. Janssen PG, Gorter KJ, Stolk RP, Rutten GE. Screen detected subjects with type 2 diabetes and impaired glucose tolerance have more adverse cardiovascular risk than subjects with impaired fasting glucose especially when they are obese: the ADDITION Netherlands study. Prim Care Diabetes. 2007;1(2):69-74.

45. CentersforDiseaseControlandPrevention. Prevalence of Overweight and Obesity Among Adults with Diagnosed Diabetes-United States, 1988-1994 and 1999-2002. Morbidity and Mortality Weekly Report. 2004;53(45):1066-8.

46. Nguyen NT, Magno CP, Lane KT, Hinojosa MW, Lane JS. Association of hypertension, diabetes, dyslipidemia, and metabolic syndrome with obesity: findings from the National Health and Nutrition Examination Survey, 1999 to 2004. J Am Coll Surg. 2008;207(6):928-34.

47. Paramsothy $P$, Knopp R, Bertoni AG, Tsai MY, Rue T, Heckbert SR. Combined hyperlipidemia in relation to race/ethnicity, obesity, and insulin resistance in the Multi-Ethnic Study of Atherosclerosis. Metabolism. 2009;58(2):212-9.

48. Kinosian B, Glick H, Garland G. Cholesterol and coronary heart disease: predicting risks by levels and ratios. Ann Intern Med. 1994;121(9):641-7.

49. Bass KM, Newschaffer CJ, Klag MJ, Bush TL. Plasma lipoprotein levels as predictors of cardiovascular death in women. Arch Intern Med. 1993;153(19):2209-16.

50. Kern PA, Saghizadeh M, Ong JM, Bosch RJ, Deem R, Simsolo RB. The expression of tumor necrosis factor in human adipose tissue. Regulation by obesity, weight loss, and relationship to lipoprotein lipase. J Clin Invest. 1995;95(5):2111-9.

51. Hotamisligil GS, Arner P, Caro JF, Atkinson RL, Spiegelman BM. Increased adipose tissue expression of tumor necrosis factor-alpha in human obesity and insulin resistance. J Clin Invest. 1995;95(5):2409-15.

52. Poirier $P$, Lemieux I, Mauriege $P$, Dewailly E, Blanchet C, Bergeron J, et al. Impact of waist circumference on the relationship between blood pressure and insulin: the Quebec Health Survey. Hypertension. 2005;45(3):363-7.

53. Sacks FM, Bray GA, Carey VJ, Smith SR, Ryan DH, Anton SD, et al. Comparison of weight-loss diets with different compositions of fat, protein, and carbohydrates. The New England journal of medicine. 2009;360(9):859-73.

54. Astrup A, Raben A, Geiker N. The role of higher protein diets in weight control and obesity-related comorbidities. International journal of obesity. 2014.

55. Wadden TA, Webb VL, Moran CH, Bailer BA. Lifestyle modification for obesity: new developments in diet, physical activity, and behavior therapy. Circulation. 2012;125(9):1157-70.

56. Johnston BC, Kanters S, Bandayrel K, Wu P, Naji F, Siemieniuk RA, et al. Comparison of weight loss among named diet programs in overweight and obese adults: a meta-analysis. Jama. 2014;312(9):923-33.

57. Garrow JS, Summerbell CD. Meta-analysis: effect of exercise, with or without dieting, on the body composition of overweight subjects. Eur J Clin Nutr. 1995;49(1):1-10.

58. Jakicic JM, Otto AD. Physical activity considerations for the treatment and prevention of obesity. The American journal of clinical nutrition. 2005;82(1 Suppl):226s-9s.

59. Tuomilehto J, Lindstrom J, Eriksson JG, Valle TT, Hamalainen H, Ilanne Parikka P, et al. Prevention of type 2 diabetes mellitus by changes in lifestyle among subjects with impaired glucose tolerance. The New England journal of medicine. 2001;344(18):1343-50.

60. Fagard RH. Physical activity in the prevention and treatment of hypertension in the obese. Med Sci Sports Exerc. 1999;31(11 Suppl):S624-30.

61. Kraus WE, Houmard JA, Duscha BD, Knetzger KJ, Wharton MB, McCartney JS, et al. Effects of the amount and intensity of exercise on plasma lipoproteins. The New England journal of medicine. 2002;347(19):1483-92. 
62. Kang J, Robertson RJ, Hagberg JM, Kelley DE, Goss FL, DaSilva SG, et al. Effect of exercise intensity on glucose and insulin metabolism in obese individuals and obese NIDDM patients. Diabetes care. 1996;19(4):341-9.

63. Thompson PD, Buchner D, Pina IL, Balady GJ, Williams MA, Marcus BH, et al. Exercise and physical activity in the prevention and treatment of atherosclerotic cardiovascular disease: a statement from the Council on Clinical Cardiology (Subcommittee on Exercise, Rehabilitation, and Prevention) and the Council on Nutrition, Physical Activity, and Metabolism (Subcommittee on Physical Activity). Circulation. 2003;107(24):3109-16.

64. Lee IM, Skerrett PJ. Physical activity and all-cause mortality: what is the dose-response relation? Med Sci Sports Exerc. 2001;33(6 Suppl):S459-71; discussion S93-4.

65. Warburton DE, Nicol CW, Bredin SS. Health benefits of physical activity: the evidence. CMAJ. 2006;174(6):801-9.

66. Ryan D, Heaner M. Guidelines (2013) for managing overweight and obesity in adults. Preface to the full report. Obesity (Silver Spring). 2014;22 Suppl 2:S1-3.

67. Jensen MD, Ryan DH, Apovian CM, Ard JD, Comuzzie AG, Donato KA, et al. 2013 AHA/ACC/TOS guideline for the management of overweight and obesity in adults: a report of the American College of Cardiology/American Heart Association Task Force on Practice Guidelines and The Obesity Society. Circulation. 2014;129(25 Suppl 2):S102-38.

68. Gade H, Hjelmesaeth J, Rosenvinge JH, Friborg O. Effectiveness of a cognitive behavioral therapy for dysfunctional eating among patients admitted for bariatric surgery: a randomized controlled trial. Journal of obesity. 2014;2014:127936.

69. Dietrich A, Federbusch M, Grellmann C, Villringer A, Horstmann A. Body weight status, eating behavior, sensitivity to reward/punishment, and gender: relationships and interdependencies. Frontiers in psychology. 2014;5:1073.

70. McLean N, Griffin S, Toney K, Hardeman W. Family involvement in weight control, weight maintenance and weight-loss interventions: a systematic review of randomised trials. International journal of obesity and related metabolic disorders : journal of the International Association for the Study of Obesity. 2003;27(9):987-1005.

71. Avenell A, Broom J, Brown TJ, Poobalan A, Aucott L, Stearns SC, et al. Systematic review of the long-term effects and economic consequences of treatments for obesity and implications for health improvement. Health Technol Assess. 2004;8(21):iii-iv, 1-182.

72. Tong PC, Lee ZS, Sea MM, Chow CC, Ko GT, Chan WB, et al. The effect of orlistat-induced weight loss, without concomitant hypocaloric diet, on cardiovascular risk factors and insulin sensitivity in young obese Chinese subjects with or without type 2 diabetes. Arch Intern Med. 2002;162(21):2428-35.

73. Wadden T, Berkowitz R, Sarwer D, Prus-Wisniewski R, Steinberg C. Benefits of lifestyle modification in the pharmacologic treatment of obesity: a randomized trial. Archives of Internal Medicine. 2001;161(2):21828.

74. NIH, NHLaBI, NAASO. The Practical Guide: Identification, Evaluation, and Treatment of Overweight and Obesity in Adults. NIH Publication No 00-4084. 2000.

75. Siepmann M, Kirch W. Orlistat. Ein neues Medikament zur Adipositastherapie. Arzneimitteltherapie. 1998;16:302-4.

76. Hauptmann J, Jeunet F, Hartmann D. Initial studies in humans with the novel gastrointestinal lipase inhibitor Ro 18-0647 (tetrahydrolipstatin). The American journal of clinical nutrition. 1992;55:309S-13S.

77. Padwal R, Majumdar S. Drug treatments for obesity: orlistat, sibutramine, and rimonabant. Lancet. 2008;369:71-7.

78. EuropeanMedicinesAgency. Saxenda recommended for approval in weight management in adults2015 24 april 2015 [cited 201524 april]. Available from:

http://www.ema.europa.eu/docs/en_GB/document_library/Press_release/2015/01/WC500180857.pdf.

79. EuropeanMedicinesAgency. Mysimba recommended for approval in weight management in adults2014

24 april 2015 [cited 201524 april]. Available from:

http://www.ema.europa.eu/docs/en_GB/document_library/Press_release/2014/12/WC500179334.pdf. 
80. Ballantyne $\mathrm{GH}$. Measuring outcomes following bariatric surgery: weight loss parameters, improvement in co-morbid conditions, change in quality of life and patient satisfaction. Obes Surg. 2003;13(6):954-64.

81. Christou NV, Sampalis JS, Liberman M, Look D, Auger S, McLean AP, et al. Surgery decreases long-term mortality, morbidity, and health care use in morbidly obese patients. Ann Surg. 2004;240(3):416-23; discussion 23-4.

82. Fisher BL, Schauer P. Medical and surgical options in the treatment of severe obesity. American journal of surgery. 2002;184(6B):9S-16S. 


\section{CHAPTER 2}

\section{Starches, sugars and obesity}

Nutrients. 2011 Mar; 3(3):341-69

Erik E.J.G. Aller Itziar Abete Arne Astrup

J. Alfredo Martinez Marleen A. van Baak 


\begin{abstract}
The rising prevalence of obesity, not only in adults but also in children and adolescents, is one of the most important public health problems in developed and developing countries. As one possible way to tackle obesity, a great interest has been stimulated in understanding the relationship between different types of dietary carbohydrate and appetite regulation, body weight and body composition. The present article reviews the conclusions from recent reviews and meta-analyses on the effects of different starches and sugars on body weight management and metabolic disturbances, and provides an update of the most recent studies on this topic. From the literature reviewed in this paper, potential beneficial effects of intake of starchy foods, especially those containing slowly-digestible and resistant starches, and potential detrimental effects of high intakes of fructose become apparent. This supports the intake of whole grains, legumes and vegetables, which contain more appropriate sources of carbohydrates associated with reduced risk of cardiovascular and other chronic diseases, rather than foods rich in sugars, especially in the form of sugar-sweetened beverages.
\end{abstract}




\section{Introduction}

The rising prevalence of obesity, not only in adults but also in children and adolescents is one of the most important public health problems in developed and developing countries (1). Even though more and more people are becoming aware of the magnitude of the problem and the serious consequences associated to the development of obesity $(2,3)$ it continues to grow.

Lifestyle changes together with genetic predisposition play an important role in the obesity problem (4) Large numbers of new products and technological advances have led to a lifestyle characterized by the high availability of energy-dense foods and a high level of physical inactivity (5). Although, weight loss is usually not so difficult to attain, especially for people with a strong motivation, the real problem remains in the maintenance of the achieved body weight, since during this period individuals have to continue with habits learned during the intervention in an environment that promotes just the opposite. Indeed, the success rate over the long term is considered poor. Nevertheless, lifestyle change in diet and physical activity are still regarded as the primary strategy for weight loss, weight management, as well as for improving metabolic alterations (6). Dietary recommendations have not changed much over the last forty years and the most commonly recommended macronutrient distribution is still $50-60 \%$ for carbohydrates, $30 \%$ for fat and $10-20 \%$ for proteins. Energy restriction and adherence to the energy-restricted diet appear to be more important than the macronutrient distribution of such a diet in causing weight loss (7). However, increasing evidence shows that changes in protein, carbohydrate and lipid proportions could be a key factor to improve body weight regulation after a weight loss program (8). Thus, macronutrient distribution, together with food properties (energy density, satiety value, taste, metabolic response elicited, etc.), are all nutritional factors conditioning energy balance. Therefore, they have the potential to contribute to better maintenance of body weight and better metabolic regulation.

Scientific evidence shows that high-fat diets have a high energy density and low satiety value, which facilitate passive overconsumption (9). On the other hand, highprotein diets could be an alternative, since proteins have a high satiety effect that may favour energy intake control (10). Low-fat/high carbohydrate diets also seem to be effective for body weight management (11), however the amount and type of carbohydrates included influence the metabolic responses. Indeed, high carbohydrate and specifically high sugar consumption are often considered particularly harmful with respect to energy balance disturbances due to their specific properties related to postprandial metabolism, the balance between nutrient storage and oxidation, the effects on hunger and satiety, and hence on caloric intake and energy balance (Figure 1).

The present article reviews the conclusions from the latest reviews and meta-analyses, if available, on the effects of different starches and sugars on parameters of body 
weight management and metabolic disturbances and provides an update of the most recent studies on this topic.

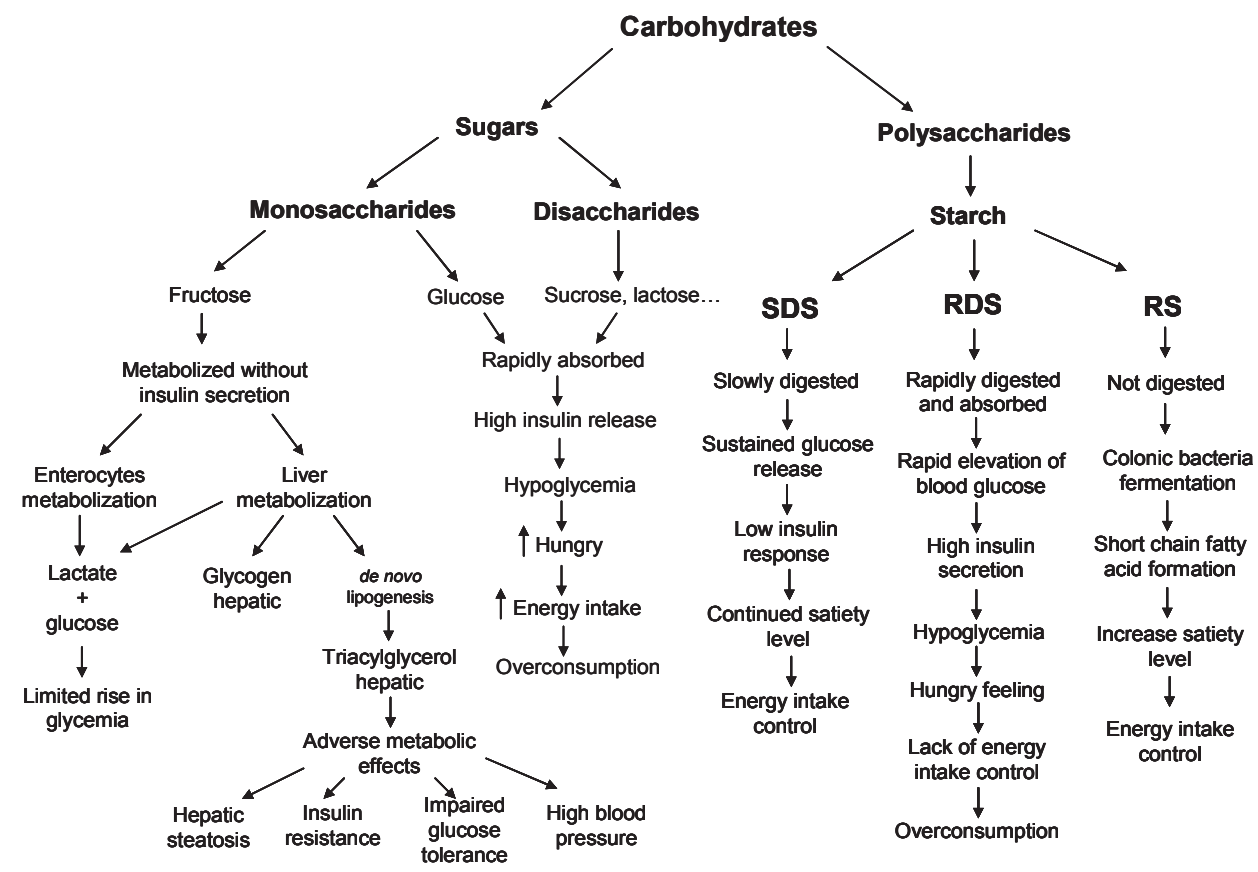

Figure 1. Carbohydrate classification and their main postprandial effects. SDS: slowly digestible starch; RDS: rapid digestible starch; RS: resistant starch.

\section{Classification of carbohydrates}

The classification of dietary carbohydrates is based on the degree of polymerization (DP) and type of linkage (alpha or beta). This divides carbohydrates into three main groups, sugars (DP 1-2), oligosaccharides (short-chain carbohydrates) (DP 3-9) and polysaccharides (DP > or $=10$ ) (12). Sugars can be grouped into monosaccharides, disaccharides and polyols or sugar-alcohols. Polysaccharides can be divided into starch and non-starch polysaccharides (Table 1). 
Table 1. Classification of dietary carbohydrates (adapted from (13)).

\begin{tabular}{lll}
\hline Class & Subgroup & Principal components \\
\hline $\begin{array}{l}\text { Sugars (mono- and } \\
\text { disaccharides) }\end{array}$ & Monosaccharides & Glucose, fructose, galactose \\
Sugar-alcohols (polyols) & Disaccharides & $\begin{array}{l}\text { Sucrose, lactose, maltose, trehalose } \\
\text { Sorbitol, mannitol, lactitol, xylitol, erythritol, isomalt- } \\
\text { itol, maltitol }\end{array}$ \\
& Maltooligosaccharides & Maltodextrins \\
& $\begin{array}{l}\text { (alpha-glucans) } \\
\text { Non-alpha-glucan oligosac- }\end{array}$ & Raffinose, stachyose, fructo- and galactooligosaccha- \\
& charides & rides, polydextrose, inulin \\
Polysaccharides & Starch (alpha-glucans) & Amylose, amylopectin, modified starches \\
& Non-starch polysaccharides & Cellulose, hemicellulose, pectins, hydrocolloids (e.g. \\
& & gums, mucilages, beta-glucans) \\
\hline
\end{tabular}

For the purpose of this review the term "sugars" is used for all sugars from all sources other than polyols. Specific attention will be paid to fructose, either being part of sucrose or high fructose corn syrup (HFCS), because there is (inconsistent) evidence that the consumption of fructose may be part of the cause of the obesity epidemic (14). The term "starches" in this review addresses only the starch polysaccharides (amylose, amylopectin and modified starches).

\section{Carbohydrate digestion}

Nutritional properties of carbohydrates depend on their rate and extent of digestion and absorption in the small intestine (15). The type of monosaccharide absorbed, and the presence of other nutritional components such as fat, dietary fiber, and protein, also influences the physiological response to carbohydrates.

Only monosaccharide species like glucose, fructose and galactose can be absorbed via active membrane transport systems. Disaccharides and polysaccharides have to be split into their monosaccharide components to be absorbed.

The starch source, granular structure, and the degree of isolation and processing are important factors influencing starch digestion. Moreover, starches that are relatively high in amylose content tend to be more resistant to digestion than starches with higher amylopectin content. Considering this, starch can be divided into rapidly digestible starch (RDS), slowly digestible starch (SDS), and resistant starch (RS) (16). RDS is rapidly digested and absorbed in the duodenum and proximal regions of the small intestine leading to a rapid elevation of blood glucose and usually a subsequent episode of hypoglycaemia. These rapid and large increases in blood glucose levels can further lead to cell, tissue and organ damage (17). RS (which can also be divided into different types, see Table 2 ) is not digested in the upper gastrointestinal tract but is fermented 
by the colonic microflora, producing short chain fatty acids that provide additional energy to the body along with butyrate that is beneficial to colonic health. SDS is digested slowly throughout the small intestine to provide sustained glucose release with a low initial glycemia and subsequently a slow and prolonged release of glucose, leading to prolonged energy availability, compared to more rapidly digestible starch (15).

Table 2. Classification of naturally occurring starch (adapted from (18)).

\begin{tabular}{|c|c|c|c|}
\hline \multicolumn{2}{|c|}{ Type of starch } & Example & $\begin{array}{l}\text { Probable digestion in the } \\
\text { small intestine }\end{array}$ \\
\hline \multicolumn{2}{|c|}{ Rapidly digestible starch } & Freshly cooked starchy foods & Rapid \\
\hline \multicolumn{2}{|c|}{ Slowly digestible starch } & Most raw cereals & Slow but complete \\
\hline \multicolumn{4}{|c|}{ Resistant starch } \\
\hline 1) & $\begin{array}{l}\text { Physically indigestible } \\
\text { starch }\end{array}$ & Partly milled grains and seeds & Resistant \\
\hline 2) & $\begin{array}{l}\text { Resistant starch } \\
\text { granules }\end{array}$ & Raw potato and banana & Resistant \\
\hline 3) & Retrograded starch & Cooled, cooked potato, bread, and cornflakes & Resistant \\
\hline
\end{tabular}

\section{Glycemic index and glycemic load}

The glycemic response to ingestion of a carbohydrate depends on the amount, rate of digestion, absorption and metabolism of the ingested carbohydrate. To describe the physiological effect of a food's carbohydrate content on postprandial blood glucose concentration, the glycemic index of foods (GI) has been introduced (19). The glycemic index of a food quantifies the area under the glycemic response curve (AUC) of a test food, compared to the same amount (usually $50 \mathrm{~g}$ of available carbohydrate) of a reference food, most often glucose or white bread (19). Generally, foods with a GI $\leq 55$ are classified as low GI, whereas foods with a $\mathrm{GI} \geq 70$ are classified as high $\mathrm{Gl}$ foods. Low-GI foods are those that elicit a low postprandial glucose response which, in turn, induces a lower rise in circulating insulin and related gastrointestinal hormones, such as incretins, gastric inhibitory polypeptide (GIP), and glucagon-like peptide-1 (GLP-1). The lower but sustained insulin secretion reduces free fatty acids levels improving cellular glucose metabolism (20). Consequently, blood glucose levels remain closer to baseline despite continued glucose absorption from the small intestine. In contrast, high-Gl foods increase insulin secretion leading to a postprandial hyperinsulinemia, which has a lipogenic effect.

Because the glycemic response to food ingestion not only depends on the Gl but also on the total amount of carbohydrates ingested, the concept of glycemic load (GL) has been introduced. Glycemic load is the product of a food's GI and its total available carbohydrate content: $\mathrm{GL}=[\mathrm{Gl} \times$ carbohydrate $(\mathrm{g})] / 100$. Therefore, the $\mathrm{GL}$ provides a 
summary measure of the relative glycemic impact of a typical serving of the food. Foods with a $\mathrm{GL} \leq 10$ have been classified as low $\mathrm{GL}$, and those with a value $\geq 20$ as high GL (21).

\section{Starches, obesity and factors of the metabolic syndrome}

\section{Starch intake, appetite, energy expenditure and body weight}

It is known that an excessive intake from all macronutrients, including carbohydrates, contributes to the development of obesity. As mentioned before, starch can be divided into rapidly digestible starch (RDS), slowly digestible starch (SDS) and resistant starch (RS) (Table 2). Starch foods usually contain all three of the fractions and cannot be easily separated into pure RDS, SDS and RS foods. Many interventions have been carried out to assess the involvement of starch consumption in appetite, energy expenditure and hence, in body weight regulation. Several studies have shown that higher intakes of SDS and RS are associated with increased satiety, reduced hunger and/or reduced body weight (22)

\section{Short-term effects on energy intake and satiety}

Although the mechanisms are not totally clear, a primary mechanism by which starches are thought to regulate satiety and food intake is through their effect on blood glucose. Most nutritional intervention studies use GI to compare the effects after carbohydrate consumption. Two recent reviews concluded that consumption of high-Gl foods increase hunger and decrease satiety levels in short-term human intervention studies $(23,24)$. Several newer studies have since addressed this issue. A randomized crossover study by Sands et al. (25) examined the effects of waxy maize (WM) (amylopectin, a rapidly digested starch in a slowly digested form (uncooked)) and a maltodextrinsucrose mixture (MS) (rapidly digestible carbohydrate) or white bread (control) on postprandial insulin and glucose, whole-body energy expenditure and appetite in men and women. Twelve subjects (BMI $22.2 \pm 0.7 \mathrm{~kg} / \mathrm{m}^{2}$ ) consumed $50 \mathrm{~g}$ of available carbohydrate as WM, MS or white bread on separate days. Postprandial plasma glucose, insulin and appetite (hunger, fullness, and desire to eat) were measured over $4 \mathrm{~h}$. The results indicated that consumption of uncooked WM, a slowly digestible starch, leads to lower postprandial glucose and insulin concentrations without an effect on appetite compared to the consumption of rapidly digested MS (25). Another randomized crossover study by Kristensen et al. evaluated the effect of iso-caloric meals of wholemeal wheat breads and pasta in 16 young adults, in comparison to similar refined wheat 
products on postprandial glycemia, appetite and ad libitum energy intake (EI). The meals (50 g carbohydrates) consisted of refined wheat bread (RWB), wholegrain wheat bread (WWB), refined wheat pasta (RWP) and wholegrain wheat pasta (WWP) and were served after an overnight fast. Appetite ratings and blood glucose were assessed for 180 min after which an ad libitum lunch meal was served and El measured. Results showed that wholemeal breads increased satiety measures compared to their refined counterparts; however no differences were observed in the subsequent EI (26). Likewise, another crossover study by Schroeder et al. compared the effect of whole grain high-fiber barley, whole grain wheat and refined rice-based foods on El and satiety. Forty-seven healthy subjects consumed a breakfast and, two hours later, a snack containing barley, wheat, or refined rice, followed 90 min later by an ad libitum lunch. The intake of a whole grain high-fiber barley, whole grain wheat, or refined rice breakfast and snack did not decrease energy intake at lunch (27). A randomized crossover intervention study by Aston and coworkers, consisting of two consecutive 12-week periods to assess the effects of a reduced glycemic index diet on appetite, did not find differences in satiety, nor in energy intake from a midmorning snack $2 \mathrm{~h}$ and an ad libitum lunch $4 \mathrm{~h}$ after a high or low Gl breakfast differing in Gl by 12 units at the end of the intervention period in 19 subjects (28).

Resistant starch, a fermentable carbohydrate, has been proposed to have properties similar to dietary fiber (29) and therefore could also affect satiety and exert a beneficial role in weight regulation. Some in vivo studies in humans have shown that meals high in resistant starch resulted in lower glucose and insulin responses and induced greater satiety for 2-6 h (30). Recently, a randomized double-blind, crossover study by Willis et al. compared the effects of four fibers and a low fiber treatment on satiety (22). Fibers were baked in muffins and were chosen in order to represent soluble, insoluble, and RS characteristics. Twenty healthy subjects ( 7 men and 13 women) tested the five different muffins (identical macronutrient content) in five different visits where the satiety level was evaluated postprandially for $3 \mathrm{~h}$. Results showed that subjects were less hungry after eating RS than after eating the low fiber muffin and RS stimulated less desire for food intake than the low fiber treatment.

An acute randomized, single-blind crossover study by Bodinham et al. aimed to determine the effects of consumption of $48 \mathrm{~g}$ RS on appetite, compared to an energyand available carbohydrate-matched placebo. Twenty young healthy adult males consumed either RS or placebo divided equally between two mixed meals (breakfast and lunch) on two separate occasions. Effects on appetite were assessed using an ad libitum test meal $3 \mathrm{~h}$ after the lunch was consumed and from 24-h diet diaries for the whole 24 $\mathrm{h}$ of the study day. There was a significantly lower energy intake following the RS supplement compared to the placebo supplement at both the ad libitum test meal and over the $24 \mathrm{~h}$ (31). Thus, RS intake seems to have beneficial effects on short-term satiety and food intake. 


\section{Effect on energy expenditure}

The more prolonged energy availability after SDS consumption may also lead to a more extended increase in energy expenditure. However, there are few studies regarding the effects of starch consumption on energy expenditure. A crossover study by Sands et al. examined the effects of a slowly digestible starch and rapidly digestible carbohydrate on postprandial whole-body energy expenditure and showed no differences in postprandial energy expenditure between the starches (25). An older, highly controlled 14 day study by Raben et al. compared the impact on energy expenditure of ad libitum high-sucrose vs. high-starch and a high fat diet in 20 normal weight or post-obese women in a randomized crossover design. The $24 \mathrm{~h}$ energy expenditure was significantly increased after 14 days on the sucrose diet compared with the other diets. However, this increase was explained by the increased intake of energy and fructose on this diet (32). A review by Dulloo and co-workers of energy balance studies in animal models suggested that a tendency for sugar-fed animals to have higher metabolizable energy intakes which induced increases in metabolic rate (33). The reviewed studies indicated that differences in energy balance between sugar and starch are small and that any increase in thermogenesis that occurred in some of the groups fed sugar-rich diets was in response to the higher energy intake rather than due to a lower efficiency of utilization of sucrose per se (33).

A study by Heijnen et al. described the effect of replacement of digestible starch by resistant starch on diet-induced thermogenesis (DIT) (34). Ten healthy males consumed three test meals, consisting of diluted, artificially-sweetened fruit syrup and either $50 \mathrm{~g}$ raw potato starch $(550 \mathrm{~g} \cdot \mathrm{RS} / \mathrm{kg}$ ), or $50 \mathrm{~g}$ pregelatinized potato starch $(0 \mathrm{~g} \cdot \mathrm{RS} / \mathrm{kg}$ ) or 30 g pregelatinized potato starch plus $20 \mathrm{~g}$ lactulose (670 g indigestible disaccharide $/ \mathrm{kg}$ ). The meals were served in the morning after an overnight fast. Each volunteer consumed each meal twice on six separate days in random order. Metabolic rate was measured by indirect calorimetry in the fasting state and postprandially for $5 \mathrm{~h}$. Results showed that the replacement of digestible starch by RS in a single meal lowered DIT, however, the ingestion of lactulose resulted in a substantial rise in DIT which was related to its fermentation (34). A more recent crossover study by Keogh and coworkers examined the effect of barley flour, high in soluble fiber and amylose, incorporated into breakfast and lunch compared with otherwise identical meals containing white wheat flour on the thermic effect of food. Fourteen healthy women consumed a test breakfast at 7:00 and a test lunch at 13:30. Energy expenditure was measured before and after the test lunch, showing no differences in the thermic effect of the foods (35). 


\section{Effect on body weight}

Much interest has been focused on the relationship between glycemic index and bodyweight loss or body weight regulation. Acute meal studies seem to point to an effect of glycaemic index on appetite and hence on body weight regulation, however, the results of longer-term studies of weight loss are not as clear. Indeed, recent conclusions from different reviews suggest that there is no evidence that an ad libitum diet with a low-GI causes more weight loss than a diet with a high-GI when total carbohydrate intake is not different (36). Likewise, it is also confirmed that there is insufficient evidence that an exchange of sugar for non-sugar carbohydrates in the context of a reduced-fat ad libitum diet or energy-restricted diet result in greater weight reduction (37). On the other hand, an overall systematic review suggested an overall positive effect of low glycemic or low glycemic load diets on weight loss (38). However, no clear distinction was made between these two types of diet.

A recent trial by Larsen et al. studied the effect of varying protein content and GI of an ad libitum diet on body weight maintenance after body weight loss in 773 adults, 548 of whom completed the six month trial. Both the higher protein content and the lower Gl improved completion rate and weight loss maintenance (39).

Animal studies observed that a diet high in RS reduced adipose tissue with no changes in body weight, suggesting a central role of short-chain fatty acids (40). A recent study showed that an amylose-rich, high RS, ad libitum diet resulted in both less body weight and less body fat gain than a high amylopectin, low RS, diet (41). In another study four groups of male C57BL/6J mice ( $n=10$ per group) were exposed to longterm ( 20 weeks) or short-term ( 6 weeks) isoenergetic and macronutrient matched diets only differing in starch type and as such GI. Mice fed the high GI diet showed a rapidonset (from week 5) marked increase in body fat mass compared to mice in the other three starch groups (42). In combination, the findings described above suggest that RS and SDS are attractive dietary targets for weight gain prevention and weight loss diets.

\section{Starch intake and insulin resistance}

The starch composition of food and its rate of digestion are determinants of blood glucose and insulin levels (43). Several studies have shown that higher intakes of slowly digested and resistant starches are associated with a reduced glycemic response and insulin resistance $(22,44)$, while rapidly digestible starch may lead to hyperglycemic episodes, being associated with an increased risk of insulin resistance and type 2 diabetes (45).

Most of the health benefits of SDS are deduced from low-GI foods which may have a similar glycemic response as SDS. Seal et al. 2003 (46) showed that acute testing of SDS (corn starch) produced a slow and prolonged postprandial release of glucose and 
corresponding low insulin levels throughout the digestion process without a hypoglycemic effect. However, the consumption of RDS induced a rapid increase of plasma glucose and subsequent hypoglycaemia. Moreover, SDS consumption also prolonged exogenous glucose oxidation and produced a lower level of circulating non-esterified fatty acids (NEFA).

A group of thirty-one obese subjects with elevated fasting blood glucose was randomly assigned to a two-way crossover study by Rave et al. (2007) to evaluate the potential of a whole-grain based dietary product (WG) in comparison to a nutrient-dense meal replacement product (MR) with a similar energy but higher sugar content, during a hypo-energetic diet (4-week treatment periods with a 2-week washout period between them) on fasting blood glucose and insulin resistance. Subjects replaced at least two daily meals with WG and MR, respectively, targeting for a consumption of $200 \mathrm{~g}$ of either product per day. Fasting blood glucose and insulin resistance score improved during both treatment periods. However, when variables were adjusted for the amount of body weight lost, fasting serum insulin and HOMA improved more with WG than with MR (44). Another randomized crossover study of matched diets differing only in GI and GL in 24 overweight or obese investigated the effect on insulin sensitivity. Each participant consumed both diets in random order for four weeks each, with a 4-week washout period in between. No differences in glucose metabolism factors were found (47). Thus, although a reduction of dietary glycemic response has been proposed as a means of reducing the risk of diabetes, the impact of glycemic response on markers of health is not totally clear. Overall, Ells et al. (45) proposed an increase in the consumption of SDS to reduce potential risk factors for type 2 diabetes and metabolic syndrome. Indeed, several authors suggest that certain low-Gl foods can lower glycemia not only in direct connection to a meal (acutely), but also at a consecutive standardized second meal, i.e., lunch after a test breakfast or breakfast after a test dinner, indicating improvements in insulin sensitivity or insulin economy also within a semi-acute time frame (48-51). In the case of benefits of breakfast into lunch, the key factor involved is likely the lente carbohydrate (capable of maintaining a low but sustained net increment in blood glucose) $(49,52,53)$. However, with respect to the influence of the evening meal on the response to breakfast, other properties of the low-GI foods, such as the specific amount of indigestible carbohydrates, might contribute to the improvement of glucose tolerance $(48,51)$. A study carried out by Nilsson et al. to assess whether acute glycemia and glycemia after subsequent meals can be modulated by the characteristics of cereal foods, such as glycemic index and content of indigestible carbohydrates, evaluated twelve healthy subjects who had to consume test meals in random order. In series 1 , test meals were consumed at breakfast and in series 2 , the subjects consumed test evening meals. The authors confirmed that glucose tolerance at subsequent meals can be notably improved during the course of a whole day or overnight by choosing specific low GI, whole-grain cereal products. They also suggested that a low GI may be sufficient to achieve a second-meal effect from breakfast to lunch and a specific indi- 
gestible carbohydrate mixture appears to be required to show benefits on glucose tolerance over a longer time frame $(9.5 \mathrm{~h})$, most likely mediated through colonic fermentation (54).

In this sense, a great number of authors emphasize the positive influence on insulin sensitivity of resistant starch consumption or supplementation (55-60). Diets rich in RS are associated with a reduced risk of diabetes. Animal studies have shown that high RS consumption improves insulin sensitivity via changes in ectopic fat storage $(40,61)$. However, a nutritional intervention study by Johnston et al. carried out in 20 insulin resistant subjects, showed that the consumption of RS improved insulin sensitivity, but this improvement was not related to changes in body adiposity (56). The main suggested mechanism is the colonic fermentation of indigestible carbohydrates (RS), which results in the formation of short chain fatty acids (mainly acetic, propionic, and butyric acids) (62). These metabolites may enter the circulation, and it has been suggested that certain short chain fatty acids may exert systemic effects, including benefits on glucose metabolism $(58,59)$. Another study by Robertson et al. assessed acute changes in the insoluble-fiber (resistant starch) content of the diet on postprandial glucose. Thus, ten healthy subjects consumed two identical, low-residue diets on separate occasions for $24 \mathrm{~h}$ (33\% fat; <2 g dietary fiber). One of the diets was supplemented with $60 \mathrm{~g}$ RS and the following morning a fiber-free meal tolerance test was carried out. The RS consumption led to lower postprandial glucose and insulin with higher insulin sensitivity, but also enhanced carbohydrate handling in the postprandial period the following day, which was potentially due to the increased rate of colonic fermentation (58). Likewise, a 4-week supplementation period with $30 \mathrm{~g}$ resistant starch/d compared with placebo resulted in higher insulin sensitivity and higher insulin sensitivity during a meal tolerance test. Moreover, despite lower insulin concentration, muscle glucose clearance during the meal tolerance test was also higher after resistant starch supplementation (59). Brighenti et al. (62) studied the "second-meal effect" of greater fermentation of high-GI and low-GI carbohydrates eaten during a previous meal. Ten healthy volunteers ate three breakfast test meals consisting of sponge cakes made with rapidly digestible, non-fermentable starch (high-GI meal), or slowly digestible, partly fermentable starch (low-GI meal). Five hours later, subjects were fed the same standard lunch. Both the high-GI and low-GI meals improved glucose tolerance at lunch, but, in the case of the high-GI meal the effect was concomitant with low non-esterified fatty acid concentrations and delayed gastric emptying. The authors concluded that fermentable carbohydrates, independent of their effect on a food's glycemic index, have the potential to regulate postprandial responses to a second meal.

Thus, further work needs to be done before a firm conclusion can be drawn about the optimal amount and type of dietary carbohydrate for the prevention and treatment of insulin resistance, impaired glucose tolerance and type 2 diabetes, but it is clear that SDS as well as RS are important dietary components strongly associated with health improvements and reduced metabolic risks of these prevalent diseases. 


\section{Starch intake and lipids}

Although there is strong evidence that the amount and type of fat in the diet can have strong effects on metabolism, the types of carbohydrates influencing metabolic parameters is also of great interest. In this sense, slowly digestible starch seem to be related to some benefits on lipid metabolism, while rapidly digestible starch or high glycemic index carbohydrates are associated with a higher prevalence of the metabolic syndrome (63).

Low glycemic index foods may alter serum lipids by prolonging absorption time, spreading the nutrient load, and modifying the endocrine and metabolite response to food (64). It has been also suggested that low glycemic index foods or carbohydrates that are not so resistant to absorption, but rather are slowly absorbed, possess some of the features of dietary fiber in providing a substrate for colonic bacterial fermentation (64). In the small intestine, they form lente or sustained release carbohydrates which have been related to improvements in blood lipid profiles in hyperlipidemic individuals (65). Resistant starch may lower plasma lipid levels, especially plasma cholesterol, by delaying gastric emptying, thereby limiting hepatic lipogenesis owing to less glucose as substrate and less insulin as an activator. It may also interfere with digestive enzymes decreasing substrates availability for hepatic lipid synthesis or it may interfere with micelle formation, resulting in less cholesterol absorption. Likewise, RS may inhibit hepatic cholesterol biosynthesis due to the inhibitory effects of propionate (derived from colonic fermentation of RS) on HMG-CoA reductase activity (66).

In a randomized crossover study of matched diets differing only in $\mathrm{Gl}$ and glycemic load (GL) by Shikany et al., 24 overweight or obese subjects were followed for two periods of four weeks with a 4-week washout period between them. The high-GI/GL diet resulted in significant reductions in total and low-density lipoprotein cholesterol, whereas high-density lipoprotein cholesterol concentration was significantly reduced on the high-Gl/GL diet compared with the low-Gl/GL diet (47). In larger cohort studies, low glycemic index foods or low glycemic index diets have been associated with higher HDL-cholesterol levels and reduced incidence of diabetes and cardiovascular disease (67). Likewise, in an older, metabolically controlled, study of 20 type 2 diabetic men and women fed high and low glycemic index diets for two 24-day periods by Jarvi et al., the low glycemic index diet resulted in lower serum LDL levels in comparison with the control diet (68). In a study of 38 moderately hypercholesterolemic free-living men by Turley et al., low-Gl carbohydrates were increased by the use of grains, vegetable, legumes and fruit. This increased carbohydrate consumption reduced LDL and the LDL/HDL ratio with minor changes in HDL and triglycerides (69).

Hypocholesterolemic effects have been mainly related to RS consumption, but available information is contradictory. RS seems to decrease plasma cholesterol and triglyceride concentrations (30), but little is still known about the impact of RS on lipid metabolism. Animal studies indicate that a high RS diet leads to a lower weight of fat 
depots and can reduce serum total cholesterol triacylgycerol concentrations (70, 71). In humans, five weeks of RS feeding lowered fasting cholesterol and triglyceride concentrations (72). Likewise, a study by Higgins et al. examined the relationship between RS content of a meal and postprandial/post-absorptive fat oxidation. Twelve subjects consumed meals containing $0 \%, 2.7 \%, 5.4 \%$, and $10.7 \%$ RS (as a percentage of total carbohydrate). Respiratory quotient was measured hourly. Breath samples were collected hourly following the meal and gluteal fat biopsies were also obtained at 0 and $24 \mathrm{~h}$. Resistant starch, regardless of dose, had no effect on carbohydrate metabolism, free fatty acids or triacylglycerol concentration, nor on meal fat storage. However, data from indirect calorimetry showed that an addition of $5.4 \%$ RS to the diet significantly increased postprandial fat oxidation by $23 \%$. Thus, the authors suggested that replacement of total dietary carbohydrate with RS increases postprandial lipid oxidation and may decrease fat accumulation in the long term (30).

The intervention study by Robertson et al. showed that acute changes in RS content had effects on postprandial carbohydrate concentrations, however, there was no effect on plasma triacylglycerol concentrations (58). Eight non-diabetic subjects and four subjects with diet-controlled type 2 diabetes participated in a randomized crossover study by Culling et al. (2009), using a short-term intensive dietary modification to test the influence of the nature of the carbohydrates on metabolic responses. Volunteers had to follow three isoenergetic diets, each for three days: high-fat $(50 \%$ energy from fat), high-starch and high-sugar (70\% energy from carbohydrate each). Analysis of the variables showed that fasting triacylglycerol (TG) concentrations were greatest following the high-sugar diet, and lowest following the high-fat diet. There were no differences in TG concentration on the high-starch and high-fat diets (60).

Postprandial metabolism of two starches with different rates of hydrolysis in vitro was studied by Ells et al. One contained predominantly rapidly digestible starch and the other contained predominantly slowly digestible starch. Ten healthy female volunteers ate each test starch as part of a moderate fat test meal (containing $75 \mathrm{~g}$ test starch and $21 \mathrm{~g}$ fat) in a double-blind randomized crossover design. The metabolic response to each starch was measured after an overnight fast, in an acute $6 \mathrm{~h}$ study, before and after 14 days of daily consumption of $75 \mathrm{~g}$ test starch. Significantly more rapid and greater changes were found in glucose metabolism, as well as on non-esterified fatty acids, after consumption of the rapidly digestible starch. The 14 day adaptation period did not affect any of the glycemic or lipemic variables (45).

Thus, slowly absorbable and non-absorbable carbohydrates may all influence serum lipids and modify risk factors for cardiovascular disease. Resistant starch is associated with several changes in metabolism, which may confer some health benefits. However, the effect of the products of colonic fermentation and their relation to serum lipids requires further investigation. 
Starch is classified in RDS, SDS and RS in order to characterize its nutritional property since each fraction has important physiological consequences that differently affect metabolic hormones related to body weight regulation, satiety and energy intake. Because dietary carbohydrates vary in their rate of digestion and thus in glucose release and absorption, it is conceivable that the ability to stimulate incretin hormone secretion differs among the various types of carbohydrates. A recent review suggests a critical role of low-GI and fermentable carbohydrates for appetite regulation, since short chain fatty acids (SCFA), the products of carbohydrate fermentation, seem to activate gut hormone secretion, leading to appetite suppression (55).

The main incretin hormones are glucagon-like peptide-1 (GLP-1) and glucosedependent insulinotropic polypeptide (GIP). Both play a role in the control of glucose homeostasis, and GIP is also implicated in the regulation of energy storage. Both hormones are secreted in response to ingestion of a meal. Other important hormones to be taken into account are leptin and ghrelin, which are antagonistic hormones with main roles in the regulation of food intake, energy expenditure and fat reserves (73). Leptin is a hormone mainly produced and secreted by the adipose tissue, in proportion to the amount of fat stored, which contributes to the long-term regulation of body weight by decreasing food intake and increasing energy expenditure (74). Leptin is also produced by the stomach in response to feeding, being also involved in the acute regulation of food intake acting as a satiating hormone (75). Ghrelin is a hormone with antagonistic effects to those of leptin. It is known that ghrelin stimulates food intake and rises preprandially initiating voluntary meals (76). Recently, a study carried out in animals showed that diet composition influenced leptin and ghrelin production and secretion differentially. Thus, carbohydrate feeding resulted in lower ghrelin and higher leptin levels than fat feeding (77). In a recent review (24) authors discuss the relationship between GI, leptin and ghrelin. Insulin and insulin-mediated glucose uptake and metabolism in adipose tissue affect blood leptin concentration and its diurnal pattern. The circulating ghrelin level is suppressed by carbohydrate-rich meals, presumably via glycemia and insulinemia. However, insulin-mediated leptin stimulation and ghrelin suppression per se are not consistent among studies. Thus, authors were not able to identify a clear relationship among GI, satiety-inducing leptin, and appetite-inducing ghrelin (24).

Nilsson et al. (78) studied the effect of eight cereal-based bread evening meals (50 $\mathrm{g}$ available starch), varying in $\mathrm{Gl}$ and content of indigestible carbohydrates on incretin hormones after a subsequent standardized high-GI breakfast in healthy subjects ( $\mathrm{n}=$ 15). The GLP-1 and glucose responses after the standardized breakfast were inversely related. Animal studies suggest that this effect may be mediated by bacterial colonic fermentation and formation of SCFA. Thus, low-GI whole grain foods appear to be ca- 
pable of improving glycemic and satiety control not only acutely, but also at a meal $10 \mathrm{~h}$ later (78).

A crossover study evaluated the effect of glucose and two starchy foods, varying in their content of rapidly and slowly available glucose, on plasma concentrations of GIP and GLP-1 in seven healthy volunteers (BMI $21.6 \pm 1.1 \mathrm{~kg} / \mathrm{m}^{2}$; age 23.4 years). Each volunteer was studied on three occasions at least one week apart. Test meals were: glucose, uncooked cornstarch (UCCS) and corn pasta (CP). In vitro characteristics were measured with the Englyst method, classifying the glucose fraction into rapidly available glucose (RAG) or slowly available glucose (SAG) to reflect the likely rate of release and absorption of glucose. CP contained more RAG than UCCS (89 and 28\% of the total amount of carbohydrates, respectively). After the test meal was ingested, blood samples were taken at frequent intervals for $8 \mathrm{~h}$. GIP concentrations were higher after ingestion of glucose than that after CP and UCCS ingestion. The intake of UCCS induced a sustained elevation of the incretin hormone of glucagon-like peptide- 1 in the later stage (180-300 min), which can decrease gastric emptying and improve glycemic response (79), as well as prolong satiety (80).

An animal study showed that the inclusion of RS in the diet affected energy balance through its effect as stimulator of gut peptide YY (PYY) and GLP-1 expression (81). More recently, a crossover study by Tarini and Wolever evaluated the effect of fermentable fiber on gut hormone responses in healthy subjects. Thus, 12 subjects were studied for $6 \mathrm{~h}$ after consuming $400 \mathrm{~mL}$ drinks, containing $80 \mathrm{~g}$ high-fructose corn syrup (80HFCS), $56 \mathrm{~g}$ HFCS (56HFCS) or $56 \mathrm{~g}$ HFCS plus $24 \mathrm{~g}$ of fermentable fiber (inulin). Four hours after the test drink a standard lunch was served. Inulin significantly increased plasma glucagon-like peptide- 1 concentrations at $30 \mathrm{~min}$, and reduced ghrelin at $4.5 \mathrm{~h}$ and $6 \mathrm{~h}$. These results support the hypothesis that dietary fermentable fiber increases the production of colonic short-chain fatty acids, which may reduce postprandial free fatty acid concentration and favorably affects the release of gut hormones that regulate food intake (57).

All these properties make RS and SDS attractive dietary targets for the development of weight maintenance diets and diets for the prevention and treatment of metabolic syndrome and cardiovascular risk factors.

\section{Sugars, obesity and factors of the metabolic syndrome}

The three macronutrients have different effects on satiety, with protein being the most and fat the least satiating. This hierarchy of macronutrients is also present in their thermic effect, where protein elicits the highest and fat the lowest thermic response after isocaloric ingestion (82). Also, a diet combining a high protein and carbohydrate content results in a greater $24 \mathrm{~h}$ energy expenditure compared to a diet high in fat (83). The macronutrient composition of the diet also affects the risk for cardiovascular dis- 
ease. Thus, when in an ad libitum diet dietary macronutrient composition is varied, this can result in changes in body weight and cardiometabolic risk. As suggested before, different types of carbohydrates may also play a role. In the previous section, differences between types of starches have been discussed. Here we will discuss whether variations in the sugars content and type of sugars in the diet also play a role.

For a healthy diet, recommended dietary macronutrient composition according to the Institute of Medicine should be 10-35\% protein, 20-35\% fat and 45-65\% carbohydrate (84). Sugars, as part of the carbohydrates, are an important part of our diet. The Institute of Medicine advises an intake of sugars $<25 \%$ of daily energy. Available data from national dietary surveys show a worldwide consumption of sugars between $10 \%$ and $21 \%$ of daily energy intake (85). With respect to added sugars, the WHO recommends an added sugar intake of no more than $10 \%$ of daily energy. For Europe, the European Food Safety Authority (EFSA) notes that a number of European Union (EU) national authorities have established upper limits for population average intake or individual intake of added sugars $<10 \%$ of daily energy, but others have not. It is also noted that the average intake of (added) sugars in some EU Member States exceeds $10 \%$ of daily energy, especially in children (86).

Intake of sugars, appetite, energy expenditure and body weight

Because different types of mono- and disaccharides have been shown to exert different effects on hunger and satiety, energy intake and energy expenditure, they may also exert different body weight effects. Therefore, modifying these types of sugars in the diet may sustain better weight management.

Sugars, appetite and energy intake

Given the different physiological effects of sugars (Figure 1), one could assume that they also have a different effect on appetite and satiety. Tappy and Lé propose two potential mechanisms that could explain why fructose may elicit lower short-term satiation than equivalent doses of glucose or starches: (1) because of the more than five times lower glycemic index compared to glucose, fructose will elicit a lower glycemic response compared to an equivalent amount of glucose ingested; and (2) a meal containing fructose evokes less suppression of the orexigenic hormone ghrelin and less increase in the satiety hormone leptin than a meal containing an equivalent amount of glucose (87).

In 2009 Moran reviewed the results of preload studies comparing glucose, sucrose and fructose in either pure solutions or in mixed solutions/meals with respect to satiety (88). Moran concluded that differences in food intake after different preloads are more 
related to the timing of ingestion relative to a test meal situation, whether the sugars are administered as pure sugars or as components of a dietary preload, and the overall volume of the preload than to intrinsic differences among the sugars. Moreover, the practical relevance of the results from preload studies with fructose intakes higher than normal is questionable (88). Dolan et al. reviewed long-term studies with dietary fructose intake up to $100 \mathrm{~g} /$ day. They conclude that there is no convincing evidence that such amount of fructose intake compared to sucrose or glucose is associated with an increase in food intake (89).

There are only a few studies that have examined the effects of other sugars on appetite. A study by Bowen et al. investigated the short-term effects of four $1 \mathrm{MJ}$ liquid preloads containing glucose, lactose, casein or whey, on appetite and energy intake. Acute appetite and energy intake was lower after consumption of lactose compared with glucose, which was consistent with differences in plasma ghrelin (90).

Artificial sweeteners are widely used in diet products because they are sweeter than natural sweeteners but lack the calories. Yang reviewed epidemiological and intervention studies and concluded that artificial sweeteners do not account for more weight loss compared to natural sweeteners. In some studies diet soda consumption was even associated with weight gain. Based on additional evidence from experimental studies, Yang suggests that the reason for these findings could be that artificial sweeteners do not activate food reward pathways in the same fashion as natural sweeteners. In artificial sweeteners there is a lack of calories after the sweet taste, which may result in compensatory overeating (91).

In conclusion, there is no consistent evidence that there is a difference in satiety and food intake after consumption of equal amounts of different sugars, either for the short- or long-term. On the other hand, artificial sweeteners increase appetite and the desire to eat compared to natural sweeteners, which makes their relevance for weightloss purposes questionable.

Dissolved vs. solid sugars: effect on appetite and energy intake

It has been hypothesized that solid carbohydrates suppress subjective appetite and short-term food intake more than a carbohydrate in dissolved form (92). Akhaven et al. therefore compared the effect of eating solid vs. dissolved foods. Test foods were $75 \mathrm{~g}$ of sucrose in solid form or dissolved in $300 \mathrm{ml}$ water and an isocaloric 50/50 mixture of the monosaccharides glucose and fructose in liquid form. They found that the postprandial area under the curve of appetite was not different between the solid and dissolved forms of sugars nor was food intake from an ad libitum pizza lunch one hour later (93). 
Sugars and energy expenditure

Given the different metabolic pathways of sugars, different sugars may also have different effects on energy expenditure. Tappy et al. compared the increment in energy expenditure (EE) after ingestion of $75 \mathrm{~g}$ of fructose compared to the same amount of glucose. Fructose increased EE significantly more than glucose (94). Schwarz and colleagues found a similar difference after comparing intravenous fructose and glucose administration (95). Brundin and Wahren confirmed these findings (96). Sharief and Macdonald compared the effects of glucose with galactose, lactose, maltose, sucrose, a glucose-galactose mixture and a glucose-fructose mixture, on EE. Only sucrose and the glucose-fructose mixture showed a significant increase in EE compared to glucose (97). Blaak and Saris compared the thermogenic response to $75 \mathrm{~g}$ naturally enriched fructose, glucose, cane sugar, and digestible corn starch (all mixed with $400 \mathrm{~mL}$ water). The energy expenditure was higher after fructose and sucrose than after glucose and starch (98). Thus, the more pronounced increase in EE after sucrose or glucose-fructose mixture ingestion is due to the fructose component. The EE increasing effect of fructose is probably due to the energy cost of fructose metabolism to glucose in the liver and continued gluconeogenesis (95).

With respect to the effect of sugars on EE it can be concluded that only fructose or mixtures containing fructose significantly increase EE compared to other sugars.

Sugars, body weight and body composition

Three reviews concerning this topic have been published recently. In the first review by Van Baak and Astrup, the authors conclude that observational studies show fairly consistent inverse associations between the carbohydrate content and content of sugars in the diet and body weight and adiposity measures. This is supported by a limited number of randomized controlled trials (RCTs) that consistently show lower body weight when fat in the diet is replaced by carbohydrates, whether in the form of sugars or as starches (37). In the second review, Ruxton et al. support these findings (85). The third review by Dolan et al. focuses on dietary consumption of fructose. Here it is concluded that there is no convincing evidence from long-term studies that fructose ingestion of up to $100 \mathrm{~g} /$ day instead of glucose or sucrose is associated with an increase in body weight (89).

A recent weight-loss intervention study, among 169 overweight/obese Scottish women, supports these conclusions. The study sample was divided into three groups. Group 1 received advice to reduce energy, total fat and sucrose for three months; Group 2 received advice to reduce energy and total fat and maintain sucrose intake at $10 \%$ energy for three months; and Group 3 acted as controls and received no dietary advice. Both Groups 1 and 2 were successful in reducing energy intakes and the per- 
centage energy from fat in their diet. Group 1 was also successful in reducing percentage energy from sucrose at three months. These dietary changes resulted in significant reductions in body weight, percentage body fat and the waist-to-hip ratio in both groups, but there was no significant difference in weight-loss between group 1 and 2 . Reducing sucrose consumption to below $10 \%$ of total energy therefore did not lead to extra weight loss (99).

Role of sugar-sweetened beverages

Consumption of sugar-sweetened beverages (SSB's) is often linked to an excess in caloric intake and the increasing prevalence of obesity. It is hypothesized that the calories in SSB's have little effect on satiety and therefore easily lead to over-consumption (92). SSB's are defined as drinks with added sugars, excluding milk and pure fruit juices.

In their review on sugars and body weight, Van Baak and Astrup concluded that a limited number of randomized controlled trials supported the positive association between BMI and SSB consumption that is found in observational studies, although not consistently. A number of additional reviews on this topic has been published in the last two years $(37,100-103)$. In 2008, Gibson published a systematic review on 23 crosssectional, 17 prospective and four intervention studies in adults and children, as well as six reviews, using BMI, weight (gain) or adiposity as endpoints. She concludes that there is little evidence from epidemiological studies that SSB's are more obesogenic than any other source of energy and that there is a need for more intervention studies, especially among overweight consumers of SSB's, which use reliable measurements of diet and physical activity, and with an adequate length of follow-up (101).

A review of the literature between 1966 and 2006 on the relationship between SSB's and weight gain by Wolff and Dansinger (102) revealed that six of 15 crosssectional and six of 10 prospective cohort studies identified statistically significant associations between soft drink consumption and increased body weight. There were five randomized clinical trials; the two that involved adolescents indicated that efforts to reduce sugar-sweetened soft drinks slowed weight gain. In adults, three small experimental studies also suggested that consumption of sugar-sweetened soft drinks caused weight gain. None of these trials in adults however was longer than 10 weeks and they all had a rather small study population. The authors conclude that although soft-drink consumption has increased over the last decades, the evidence of SSB-related weight gain is weak. In conclusion, they call for more comprehensive intervention trials designed to evaluate the effects of soft drink consumption on body weight and cardiovascular risk factors (102).

Olsen and Heitman (literature up to 2007 but mostly overlapping with Wolff and Dansinger), concluded that a high intake of calorically sweetened beverages can be regarded as a determinant for obesity. However, there seems to be no support that the 
association between intake of calorically sweetened beverages and obesity is mediated by increased energy intake, and alternative biological explanations should be explored (103).

Most recently, Malik et al. concluded that SSB intake is a significant contributor to weight gain, in part because of incomplete compensation for liquid calories at subsequent meals. They also report that longer studies, with a greater numbers of participants, which do not adjust for potential mediators of effect such as energy intake, would report stronger and more consistent results (100). This literature suggests that the evidence of a relationship between SSB consumption and weight gain is inconclusive.

Dissolved vs. solid sugars

Liquid foods may have a different effect on satiety and food intake compared with solid foods. One explanation for this difference is the absence of chewing when ingesting beverages, which may result in decreased pancreatic exocrine and endocrine responses compared with the ingestion of solid foods. Beverages are also emptied from the stomach at a higher rate than solid foods and may induce weaker signals in the gastrointestinal tract that would lead to inhibition of food intake (104).

Van Baak and Astrup most recently reviewed this topic and concluded that, from RCTs, there is no support for the hypothesis that sugars in liquids have a detrimental effect on body weight compared with solid forms of sugar. Evidence from a small number of acute studies with respect to satiety and energy intake compensation is equivocal. They call for more RCTs of sufficient size and duration in this area (37). Since then, there has been only one RCT comparing ingestion of calories in solid form or dissolved in liquids on body weight change.

Chen et al. compared the intake of liquid calories with solid calories on body weight change within the PREMIER trial population. PREMIER is an 18 month multicenter randomized trial designed to test the blood pressure lowering effects of two multicomponent behavioral interventions in adults with prehypertension or stage 1 hypertension. Liquid calorie intake was calculated as the sum of calories from seven beverage categories (including SSBs, diet drinks, milk, 100\% juice, coffee and tea with and without sugar, and alcohol). Solid calorie intake was calculated by subtracting liquid calories from total calories. A reduction of $100 \mathrm{kcal} /$ day in liquid calorie intake was associated with $0.3 \mathrm{~kg}$ of weight loss at six months and of $0.2 \mathrm{~kg}$ at 18 months. A reduction in solid calorie intake of $100 \mathrm{kcal} /$ day was associated with a $0.06 \mathrm{~kg}$ weight loss at six months and of $0.09 \mathrm{~kg}$ at 18 months. Reducing liquid calorie intake resulted in more weight loss than a reduction in solid calorie intake, but only the difference at six months reached statistical significance. The comparison of the individual beverages showed that only SSB in- 
take was significantly associated with weight change. A reduction in SSBs by one serving/day ( $355 \mathrm{~mL}$ ) was associated with a weight loss of $0.5 \mathrm{~kg}$ at six month and of $0.7 \mathrm{~kg}$ at 18 months (104).

Although the study by Chen is about liquid vs. solid calories rather than sugars, it does add to the body of evidence that a reduction in liquid calories, which were mainly derived from SSB intake, has a greater effect on weight loss compared to a reduction in solid calories.

\section{Sugars and insulin resistance}

Insulin resistance and impaired glucose tolerance are common co-morbidities in the obese population. Sugars are known to have a negative influence on the incidence of type 2 diabetes. Over the last years, several large studies have been conducted to study the relationship between sugar intake and the incidence of type 2 diabetes.

Laville and Nazare reviewed 21 intervention-, prospective- and cross-sectional trials between 1979 and 2007 on the relationship between sugars, insulin resistance and diabetes to determine the level of proof concerning the association of sugars consumption and diabetes (105). They concluded that these studies failed to demonstrate an obvious relationship between the total intake of sugars and glycemic control, or risk to develop a type 2 diabetes and particularly specific evidence is missing in terms of sucrose effect on diabetes. Concerning fructose, there are still discrepancies between studies about the long-term deleterious effect on diabetes development. But its effect on lipogenesis and triglyceridemia has to be taken into account, considering the growing use of sugar, and thus fructose-containing foods (105).

To determine the association between surrogate markers of insulin resistance (fasting insulin, fasting glucose, homeostatic model assessment of insulin resistance (HOMA$\mathrm{IR})$, and the insulin sensitivity index (ISI $\left.\mathrm{I}_{0.120}\right)$ ) and SSB consumption, Yoshida et al. used data from 2500 subjects with an average age of 54 years from the Framingham Offspring Study. 53\% of the study population consumed SSB's and did this with an average of two servings per week. After adjustment for potential confounding variables, the frequency of SSB intake was positively associated with fasting insulin. The associations between the frequency of SSB consumption and fasting plasma insulin and HOMA-IR remained statistically significant after further adjustment for dietary glycemic index, fruit intake, or vegetable intake. No significant associations were found between SSB intake and fasting glucose or ISI0.120. In this study, the HOMA-IR largely reflected fasting insulin concentrations. Both insulin resistance and $\beta$-cell dysfunction precede type 2 $\mathrm{DM}$, and thus increased consumption of calorically sweetened beverages containing rapidly absorbable simple sugars may contribute to an increased risk of type 2 DM (106). 
Teff et al. compared the effect of glucose and fructose, consumed in the form of sweetened beverages with isocaloric mixed nutrient meals, on circulating hormones and lipids in obese men and women. In comparison with glucose, consumption of fructose-sweetened beverages results in decreased insulin secretion, a reduced diurnal leptin profile, and increased postprandial TG concentrations in obese individuals, independent of insulin sensitivity. In addition, the effect of fructose to increase TGs was augmented in obese subjects with insulin resistance. These data suggest that overconsumption of dietary fructose may exacerbate the adverse metabolic profiles in obese individuals, particularly those with existing insulin resistance and may therefore increase the risks for developing diabetes and CVD (107).

Malik and colleagues published a meta-analysis on SSB intake and risk of metabolic syndrome and type 2 diabetes. For their analysis they included 11 prospective cohort studies, eight studies with endpoint type 2 diabetes and three studies with endpoint metabolic syndrome, in total more than 310,000 individuals. They compared the most extreme categories of SSB intake, being none or one serving/month with 1-2 serving/day. According to their analysis, subjects in the highest category, had a $20 \%$ greater risk of developing the metabolic syndrome and $26 \%$ greater risk of developing type 2 diabetes, compared to subjects in the lowest category (108).

From the above literature, it can be concluded that when data of prospective cohort studies are combined in a meta-analysis, an increased sugar intake, being either glucose or fructose and mostly in the form SSBs, increases the risk of developing insulin resistance and type 2 diabetes, especially in the obese. However, when single intervention, prospective and cross-sectional trials are reviewed, this relationship is often not found (105). Also, fructose seems to have more detrimental effect on developing insulin resistance than glucose.

\section{Sugars and serum lipids}

Although the mechanism of how carbohydrates affect serum lipids is not completely understood, it has been suggested that these effects could be mediated by fructose. Fructose has been shown to increase de novo lipogenesis and triglyceride synthesis in the liver, and secretion of very low-density lipoproteins. Fructose also appears to decrease the peripheral clearance of lipids (109).

Dolan et al. reviewed the effect of dietary fructose on triglyceride levels in shortand long-term feeding studies in healthy normal-weight individuals (89). They concluded that the majority of acute studies show a slight increase in postprandial plasma TG levels after ingestion of fructose compared to other types of carbohydrates. Schaefer and colleagues support these findings (110). In the long-term (> 1 day) however, Dolan et al. report that there is no evidence that plasma TG are increased after ingestion of up to $133 \mathrm{~g} /$ day fructose in women and $136 \mathrm{~g} /$ day fructose in men, when it is not con- 
sumed in caloric excess (89). Schaefer et al. on the contrary found significant increases in fasting TG and LDL cholesterol concentrations by fructose in 4- to 6-week studies directly comparing glucose and fructose at $20-25 \%$ of total energy intake. No metabolic differences were found between sucrose and high-fructose corn syrup (HFCS). Another review by Johnson et al. also concluded that sugar intake appears to be associated with increased TG levels, but that the effects of sugar intake on HDL-C and LDL-C remain unclear (109).

Recent studies add to this evidence. Higher intakes of sugars from the candy/soda food group, from fruit-containing beverages, and from sweetened dairy foods are associated with significant increases in TG, VLDL-C and HOMA-IR in high BMI African American children (111). Although the authors did not divide sugars into glucose or fructose, it can be assumed that their sugars are mostly fructose, because candy/soda, fruitcontaining beverages and sweetened dairy foods are mostly sweetened with sucrose. A large cross-sectional study among 6113 U.S. adults revealed that increasing added sugar consumption is associated with lower HDL-C levels, higher TG levels, and higher ratios of TG to HDL-C (112). Duffey and colleagues analyzed data from the CARDIA (Coronary Artery Risk Development in Young Adults) study. They reported that a higher SSB consumption was associated with increased risk of developing high TG and high LDL-C (113).

These studies suggest a relationship between added sugars and increases in TG, VLDL-C and LDL-C, and decreased HDL-C levels. The effects appear to be related to the fructose in the added sugars. Since added sugars have a detrimental effect on serum lipids they are likely to increase the risk of cardiovascular disease.

\section{Sugars and blood pressure}

Elevated blood pressure is one of the components of the metabolic syndrome. Already in the 1960s, a relationship between sugar consumption and blood pressure was suggested (114). Since then, this has been a much debated issue. Johnson reviewed several possible mechanisms through which sugars, and in particular fructose, can cause hypertension. One of these mechanisms is that fructose causes an increase in uric acid concentrations that subsequently causes a reduction in the concentrations of endothelial nitric oxide, which is linked to hypertension (115). Johnson et al. conclude in their review that the results from human studies are inconsistent and that the chronic effects of a high intake of simple sugars on blood pressure remains uncertain (109).

A number of additional studies on the effect of sugars consumption have been published more recently. Bidwell and colleagues studied the effects of either a glucose (100 g dextrose in $300 \mathrm{~mL}$ water) or isocaloric glucose-fructose (glucose:fructose; 45:55 $\mathrm{g}$ in $300 \mathrm{~mL}$ ) beverage on posprandial endothelial function and blood pressure. No differences in postprandial endothelial function and blood pressure responses between 
the two beverages was found (116). In a prospective cohort study among 2774 young adults, Duffey et al. found an increased risk for hypertension with higher SSB consumption (113). Jalal et al. investigated whether increased fructose intake from added sugars was associated with an increased risk for elevated blood pressure using crosssectional data from NHANES involving 4528 adults without history of hypertension. After adjustment for confounders, increased fructose intake of $\geq 74 \mathrm{~g} / \mathrm{day}$ was associated with higher odds of elevated BP levels $(26,30$, and $77 \%$ higher risk for BP cutoffs of $\geq 135 / 85, \geq 140 / 90$, and $\geq 160 / 100 \mathrm{mmHg}$, respectively(117)).

There is only a limited number of RCTs that investigated the effects of sugars on blood pressure. These studies do not provide sufficient evidence for a positive relationship between total intake of sugars and blood pressure. Larger well controlled RCTs should be conducted to reveal whether there is a relationship or not, and whether there is a specific role for dietary fructose consumption in this relationship.

\section{Intake of sugars and hormonal responses}

Insulin, leptin, peptide YY, ghrelin and glucagon-like peptide-1 (GLP-1) are hormones that all have an effect on food intake regulation and/or satiety. Differences in these hormones after consumption of different sugars may contribute to their effects on body weight and metabolic risk. Most studies compared fructose (as part of HFCS or sucrose) with glucose.

Stanhope reviewed the endocrine and metabolic effects of beverages sweetened with glucose, fructose or high-fructose corn syrup. They conclude that in both short-term and long-term studies fructose consumption compared to glucose consumption resulted in decreased circulating levels of insulin and leptin. Long-term high fructose consumption could therefore lead to increased caloric intake or decreased energy expenditure, and contribute to weight gain and obesity (118).

No studies were found that compared the effect of different sugars on PYY in humans. In rats, circulating total PYY levels were significantly increased in rats drinking glucose or sucrose (and not fructose) for $24 \mathrm{~h}$ compared to rats drinking water. These effects disappeared after one week. After two weeks PYY levels were significantly lower for all sugar solutions compared to water. Two weeks of fructose drinking significantly increased serum ghrelin levels compared to glucose, sucrose or water. After two weeks, serum leptin levels were significantly increased after consuming all sugar solutions compared to water. The authors propose that the increased levels of total ghrelin and decreased levels of total PYY after two weeks suggest that the rats are receiving signals to continue eating, thus promoting the hyperphagia induced by the sugar solutions (119).

Melanson et al. reviewed short-term studies comparing the effects of HFCS and sucrose on plasma insulin, ghrelin, leptin and GLP-1, but did not find any differences 
(120). Teff et al (121) studied the effects of consuming fructose- or glucose-sweetened beverages with meals in 12 normal weight women on circulating glucose, insulin, and leptin concentrations as well as ghrelin, GLP-1, and GIP over a $24 \mathrm{~h}$ period. When fructose-sweetened beverages were consumed with meals, this resulted in lower circulating insulin and leptin and higher ghrelin and TG levels compared with consumption of glucose-sweetened beverages (121).

From the above we can conclude that the hormonal responses of fructose compared to glucose could promote the development of obesity when fructose in consumed rather that glucose.

\section{Conclusions}

There are only a few studies that have directly compared the effect of dietary intake of sugars and starches on body weight and parameters of the metabolic syndrome. A study by Raben et al. studied the replacement of dietary fat by sucrose or starch on 14 days ad libitum energy intake and body weight in 20 healthy normal-weight, partly post-obese, subjects (32). Body weight and fat mass decreased significantly on the starch diet (by $0.7 \pm 0.2 \mathrm{~kg}$ and $0.4 \pm 0.1 \mathrm{~kg}$, respectively, $\mathrm{P}<0.05$ ), whereas no changes were observed on the fat or sucrose diets. However, it is not clear whether the between-group differences were statistically significant. The starch-rich diet was also associated with lower total cholesterol, LDL, fasting and non-fasting TG, and nonfasting FVIIc than the sucrose-rich diet (122). In the CARMEN trial (11), participants randomized to an ad libitum reduced fat, high starch diet lost $1.8 \mathrm{~kg}$, whereas those randomized to the ad libitum reduced fat, high simple carbohydrates diet lost $0.9 \mathrm{~kg}$ (betweengroup difference not statistically significant). Thus, in both studies body weight loss was larger on an ad libitum high starch diet than on a high sugars diets and are suggestive for a more beneficial effect of starch than sugars intake on body weight. The combination of literature reviewed in this paper, suggesting potential beneficial effects of intake of starches, especially those containing slowly-digestible and resistant starches, and potential detrimental effects of high intakes of fructose, support the intake of whole grains, legumes and vegetables. These contain more appropriate sources of carbohydrates associated with reduced risk of cardiovascular and other chronic diseases, rather than foods rich in sugars, especially in the form of sugar-sweetened beverages.

\section{Conflict of Interests}

EA, IA and JAM have no conflict of interest related to sugars and starches. 
AA serves on advisory boards of the European Almond Advisory Board, Jennie Craig, and Kraft. The Department of Nutrition at the University of Copenhagen has received research support from more than 100 food companies for several studies. He has received payment for lectures from dairy companies.

MvB is recipient of research grants and honoraria as speaker from a number of Dutch and international companies and has no conflict of interest related to sugars and starches.

\section{References}

1. Wiegand S, Keller KM, Robl M, L'Allemand D, Reinehr T, Widhalm K, et al. Obese boys at increased risk for nonalcoholic liver disease: evaluation of 16390 overweight or obese children and adolescents. Int J Obes (Lond). 2010.

2. Deville-Almond J, Tahrani AA, Grant J, Gray M, Thomas GN, Taheri S. Awareness of Obesity and Diabetes: A Survey of a Subset of British Male Drivers. Am J Mens Health. 2010.

3. Rudolph H, Bluher S, Falkenberg C, Neef M, Korner A, Wurz J, et al. Perception of body weight status: a case control study of obese and lean children and adolescents and their parents. Obes Facts. 2010;3(2):83-91.

4. Garaulet M, Corbalan-Tutau MD, Madrid JA, Baraza JC, Parnell LD, Lee YC, et al. PERIOD2 variants are associated with abdominal obesity, psycho-behavioral factors, and attrition in the dietary treatment of obesity. J Am Diet Assoc. 2010;110(6):917-21.

5. Chaput JP, Tremblay A. Obesity and physical inactivity: the relevance of reconsidering the notion of sedentariness. Obes Facts. 2009;2(4):249-54.

6. Hamman RF, Wing RR, Edelstein SL, Lachin JM, Bray GA, Delahanty L, et al. Effect of weight loss with lifestyle intervention on risk of diabetes. Diabetes Care. 2006;29(9):2102-7.

7. Sacks FM, Bray GA, Carey VJ, Smith SR, Ryan DH, Anton SD, et al. Comparison of weight-loss diets with different compositions of fat, protein, and carbohydrates. N Engl J Med. 2009;360(9):859-73.

8. Abete I, Astrup A, Martinez JA, Thorsdottir I, Zulet MA. Obesity and the metabolic syndrome: role of different dietary macronutrient distribution patterns and specific nutritional components on weight loss and maintenance. Nutr Rev. 2010;68(4):214-31.

9. Green SM, Wales JK, Lawton CL, Blundell JE. Comparison of high-fat and high-carbohydrate foods in a meal or snack on short-term fat and energy intakes in obese women. Br J Nutr. 2000;84(4):521-30.

10. Clifton P. High protein diets and weight control. Nutr Metab Cardiovasc Dis. 2009;19(6):379-82.

11. Saris WH, Astrup A, Prentice AM, Zunft HJ, Formiguera X, Verboeket-van de Venne WP, et al. Randomized controlled trial of changes in dietary carbohydrate/fat ratio and simple vs complex carbohydrates on body weight and blood lipids: the CARMEN study. The Carbohydrate Ratio Management in European National diets. Int J Obes Relat Metab Disord. 2000;24(10):1310-8.

12. Cummings JH, Stephen AM. Carbohydrate terminology and classification. Eur J Clin Nutr. 2007;61 Suppl 1:S5-18.

13. Palou A, Bonet ML, Pico C. On the role and fate of sugars in human nutrition and health. Introduction. Obes Rev. 2009;10 Suppl 1:1-8.

14. Wiernsperger N, Geloen A, Rapin JR. Fructose and cardiometabolic disorders: the controversy will, and must, continue. Clinics (Sao Paulo). 2010;65(7):729-38.

15. Zhang G, Hamaker BR. Slowly digestible starch: concept, mechanism, and proposed extended glycemic index. Crit Rev Food Sci Nutr. 2009;49(10):852-67.

16. Englyst HN, Kingman SM, Cummings JH. Classification and measurement of nutritionally important starch fractions. Eur J Clin Nutr. 1992;46 Suppl 2:S33-50. 
17. Brownlee M. A radical explanation for glucose-induced beta cell dysfunction. J Clin Invest. 2003;112(12):1788-90.

18. Annison G, Topping DL. Nutritional role of resistant starch: chemical structure vs physiological function. Annu Rev Nutr. 1994;14:297-320.

19. Jenkins DJ, Wolever TM, Taylor RH, Barker H, Fielden H, Baldwin JM, et al. Glycemic index of foods: a physiological basis for carbohydrate exchange. Am J Clin Nutr. 1981;34(3):362-6.

20. Brand-Miller J, McMillan-Price J, Steinbeck K, Caterson I. Dietary glycemic index: health implications. J Am Coll Nutr. 2009;28 Suppl:446S-9S.

21. Zhang G, Sofyan M, Hamaker BR. Slowly digestible state of starch: mechanism of slow digestion property of gelatinized maize starch. J Agric Food Chem. 2008;56(12):4695-702.

22. Willis HJ, Eldridge AL, Beiseigel J, Thomas W, Slavin JL. Greater satiety response with resistant starch and corn bran in human subjects. Nutr Res. 2009;29(2):100-5.

23. Bornet FR, Jardy-Gennetier AE, Jacquet N, Stowell J. Glycaemic response to foods: impact on satiety and long-term weight regulation. Appetite. 2007;49(3):535-53.

24. Niwano Y, Adachi T, Kashimura J, Sakata T, Sasaki H, Sekine K, et al. Is glycemic index of food a feasible predictor of appetite, hunger, and satiety? J Nutr Sci Vitaminol (Tokyo). 2009;55(3):201-7.

25. Sands AL, Leidy HJ, Hamaker BR, Maguire P, Campbell WW. Consumption of the slow-digesting waxy maize starch leads to blunted plasma glucose and insulin response but does not influence energy expenditure or appetite in humans. Nutr Res. 2009;29(6):383-90.

26. Kristensen M, Jensen MG, Riboldi G, Petronio M, Bugel S, Toubro S, et al. Wholegrain vs. refined wheat bread and pasta. Effect on postprandial glycemia, appetite, and subsequent ad libitum energy intake in young healthy adults. Appetite. 2010;54(1):163-9.

27. Schroeder N, Gallaher DD, Arndt EA, Marquart L. Influence of whole grain barley, whole grain wheat, and refined rice-based foods on short-term satiety and energy intake. Appetite. 2009;53(3):363-9.

28. Aston LM, Stokes CS, Jebb SA. No effect of a diet with a reduced glycaemic index on satiety, energy intake and body weight in overweight and obese women. Int J Obes (Lond). 2008;32(1):160-5.

29. Champ MM. Physiological aspects of resistant starch and in vivo measurements. J AOAC Int. 2004;87(3):749-55.

30. Higgins JA, Higbee DR, Donahoo WT, Brown IL, Bell ML, Bessesen DH. Resistant starch consumption promotes lipid oxidation. Nutr Metab (Lond). 2004;1(1):8.

31. Bodinham CL, Frost GS, Robertson MD. Acute ingestion of resistant starch reduces food intake in healthy adults. Br J Nutr. 2010;103(6):917-22.

32. Raben A, Macdonald I, Astrup A. Replacement of dietary fat by sucrose or starch: effects on $14 \mathrm{~d}$ ad libitum energy intake, energy expenditure and body weight in formerly obese and never-obese subjects. Int J Obes Relat Metab Disord. 1997;21(10):846-59.

33. Dulloo AG, Eisa OA, Miller DS, Yudkin J. A comparative study of the effects of white sugar, unrefined sugar and starch on the efficiency of food utilization and thermogenesis. Am J Clin Nutr. 1985;42(2):2149.

34. Heijnen ML, Deurenberg P, van Amelsvoort JM, Beynen AC. Replacement of digestible by resistant starch lowers diet-induced thermogenesis in healthy men. Br J Nutr. 1995;73(3):423-32.

35. Keogh JB, Lau CW, Noakes M, Bowen J, Clifton PM. Effects of meals with high soluble fibre, high amylose barley variant on glucose, insulin, satiety and thermic effect of food in healthy lean women. Eur J Clin Nutr. 2007;61(5):597-604.

36. Arola L, Bonet ML, Delzenne N, Duggal MS, Gomez-Candela C, Huyghebaert A, et al. Summary and general conclusions/outcomes on the role and fate of sugars in human nutrition and health. Obes Rev. 2009;10 Suppl 1:55-8.

37. van Baak MA, Astrup A. Consumption of sugars and body weight. Obes Rev. 2009;10 Suppl 1:9-23.

38. Thomas DE, Elliott EJ, Baur L. Low glycaemic index or low glycaemic load diets for overweight and obesity. Cochrane Database Syst Rev. 2007(3):CD005105.

39. Larsen TM, Dalskov SM, van Baak M, Jebb SA, Papadaki A, Pfeiffer AF, et al. Diets with high or low protein content and glycemic index for weight-loss maintenance. N Engl J Med. 2010;363(22):2102-13. 
40. Pawlak DB, Kushner JA, Ludwig DS. Effects of dietary glycaemic index on adiposity, glucose homoeostasis, and plasma lipids in animals. Lancet. 2004;364(9436):778-85.

41. Aziz AA, Kenney LS, Goulet B, Abdel-Aal el S. Dietary starch type affects body weight and glycemic control in freely fed but not energy-restricted obese rats. J Nutr. 2009;139(10):1881-9.

42. Isken F, Klaus S, Petzke KJ, Loddenkemper C, Pfeiffer AF, Weickert MO. Impairment of fat oxidation under high- vs. low-glycemic index diet occurs before the development of an obese phenotype. Am J Physiol Endocrinol Metab. 2010;298(2):E287-95.

43. Anderson GH, Cho CE, Akhavan T, Mollard RC, Luhovyy BL, Finocchiaro ET. Relation between estimates of cornstarch digestibility by the Englyst in vitro method and glycemic response, subjective appetite, and short-term food intake in young men. Am J Clin Nutr. 2010;91(4):932-9.

44. Rave K, Roggen K, Dellweg S, Heise T, tom Dieck H. Improvement of insulin resistance after diet with a whole-grain based dietary product: results of a randomized, controlled cross-over study in obese subjects with elevated fasting blood glucose. Br J Nutr. 2007;98(5):929-36.

45. Ells LJ, Seal CJ, Kettlitz B, Bal W, Mathers JC. Postprandial glycaemic, lipaemic and haemostatic responses to ingestion of rapidly and slowly digested starches in healthy young women. Br J Nutr. 2005;94(6):94855.

46. Seal CJ, Daly ME, Thomas LC, Bal W, Birkett AM, Jeffcoat R, et al. Postprandial carbohydrate metabolism in healthy subjects and those with type 2 diabetes fed starches with slow and rapid hydrolysis rates determined in vitro. Br J Nutr. 2003;90(5):853-64.

47. Shikany JM, Phadke RP, Redden DT, Gower BA. Effects of low- and high-glycemic index/glycemic load diets on coronary heart disease risk factors in overweight/obese men. Metabolism. 2009;58(12):1793801.

48. Granfeldt $\mathrm{Y}, \mathrm{Wu} \mathrm{X}, \mathrm{Bjorck} \mathrm{I}$. Determination of glycaemic index; some methodological aspects related to the analysis of carbohydrate load and characteristics of the previous evening meal. Eur J Clin Nutr. 2006;60(1):104-12.

49. Liljeberg H, Bjorck I. Effects of a low-glycaemic index spaghetti meal on glucose tolerance and lipaemia at a subsequent meal in healthy subjects. Eur J Clin Nutr. 2000;54(1):24-8.

50. Liljeberg HG, Akerberg AK, Bjorck IM. Effect of the glycemic index and content of indigestible carbohydrates of cereal-based breakfast meals on glucose tolerance at lunch in healthy subjects. Am J Clin Nutr. 1999;69(4):647-55.

51. Nilsson A, Granfeldt Y, Ostman E, Preston T, Bjorck I. Effects of GI and content of indigestible carbohydrates of cereal-based evening meals on glucose tolerance at a subsequent standardised breakfast. Eur J Clin Nutr. 2006;60(9):1092-9.

52. Jenkins DJ, Wolever TM, Taylor RH, Griffiths C, Krzeminska K, Lawrie JA, et al. Slow release dietary carbohydrate improves second meal tolerance. Am J Clin Nutr. 1982;35(6):1339-46.

53. Trinick TR, Laker MF, Johnston DG, Keir M, Buchanan KD, Alberti KG. Effect of guar on second-meal glucose tolerance in normal man. Clin Sci (Lond). 1986;71(1):49-55.

54. Nilsson AC, Ostman EM, Granfeldt Y, Bjorck IM. Effect of cereal test breakfasts differing in glycemic index and content of indigestible carbohydrates on daylong glucose tolerance in healthy subjects. Am J Clin Nutr. 2008;87(3):645-54.

55. Ford H, Frost G. Glycaemic index, appetite and body weight. Proc Nutr Soc. 2010;69(2):199-203.

56. Johnston KL, Thomas EL, Bell JD, Frost GS, Robertson MD. Resistant starch improves insulin sensitivity in metabolic syndrome. Diabet Med. 2010;27(4):391-7.

57. Tarini J, Wolever TM. The fermentable fibre inulin increases postprandial serum short-chain fatty acids and reduces free-fatty acids and ghrelin in healthy subjects. Appl Physiol Nutr Metab. 2010;35(1):9-16.

58. Robertson MD, Currie JM, Morgan LM, Jewell DP, Frayn KN. Prior short-term consumption of resistant starch enhances postprandial insulin sensitivity in healthy subjects. Diabetologia. 2003;46(5):659-65.

59. Robertson MD, Bickerton AS, Dennis AL, Vidal H, Frayn KN. Insulin-sensitizing effects of dietary resistant starch and effects on skeletal muscle and adipose tissue metabolism. Am J Clin Nutr. 2005;82(3):559-67. 
60. Culling KS, Neil HA, Gilbert M, Frayn KN. Effects of short-term low- and high-carbohydrate diets on postprandial metabolism in non-diabetic and diabetic subjects. Nutr Metab Cardiovasc Dis. 2009;19(5):345-51.

61. So PW, Yu WS, Kuo YT, Wasserfall C, Goldstone AP, Bell JD, et al. Impact of resistant starch on body fat patterning and central appetite regulation. PLoS One. 2007;2(12):e1309.

62. Brighenti F, Benini L, Del Rio D, Casiraghi C, Pellegrini N, Scazzina F, et al. Colonic fermentation of indigestible carbohydrates contributes to the second-meal effect. Am J Clin Nutr. 2006;83(4):817-22.

63. O'Sullivan TA, Lyons-Wall P, Bremner AP, Ambrosini GL, Huang RC, Beilin LJ, et al. Dietary glycaemic carbohydrate in relation to the metabolic syndrome in adolescents: comparison of different metabolic syndrome definitions. Diabet Med. 2010;27(7):770-8.

64. Jenkins DJ, Kendall CW, Axelsen M, Augustin LS, Vuksan V. Viscous and nonviscous fibres, nonabsorbable and low glycaemic index carbohydrates, blood lipids and coronary heart disease. Curr Opin Lipidol. 2000;11(1):49-56.

65. Queenan KM, Stewart ML, Smith KN, Thomas W, Fulcher RG, Slavin JL. Concentrated oat beta-glucan, a fermentable fiber, lowers serum cholesterol in hypercholesterolemic adults in a randomized controlled trial. Nutr J. 2007;6:6.

66. Chandalia M, Garg A, Lutjohann D, von Bergmann K, Grundy SM, Brinkley LJ. Beneficial effects of high dietary fiber intake in patients with type 2 diabetes mellitus. N Engl J Med. 2000;342(19):1392-8.

67. Toeller M, Buyken AE, Heitkamp G, de Pergola G, Giorgino F, Fuller JH. Fiber intake, serum cholesterol levels, and cardiovascular disease in European individuals with type 1 diabetes. EURODIAB IDDM Complications Study Group. Diabetes Care. 1999;22 Suppl 2:B21-8.

68. Jarvi AE, Karlstrom BE, Granfeldt YE, Bjorck IE, Asp NG, Vessby BO. Improved glycemic control and lipid profile and normalized fibrinolytic activity on a low-glycemic index diet in type 2 diabetic patients. Diabetes Care. 1999;22(1):10-8.

69. Turley ML, Skeaff CM, Mann JI, Cox B. The effect of a low-fat, high-carbohydrate diet on serum high density lipoprotein cholesterol and triglyceride. Eur J Clin Nutr. 1998;52(10):728-32.

70. de Deckere EA, Kloots WJ, van Amelsvoort JM. Resistant starch decreases serum total cholesterol and triacylglycerol concentrations in rats. J Nutr. 1993;123(12):2142-51.

71. Mitsuhashi Y, Nagaoka D, Ishioka K, Bigley KE, Okawa M, Otsuji K, et al. Postprandial Lipid-Related Metabolites Are Altered in Dogs Fed Dietary Diacylglycerol and Low Glycemic Index Starch during Weight Loss. J Nutr. 2010.

72. Behall KM, Howe JC. Effect of long-term consumption of amylose vs amylopectin starch on metabolic variables in human subjects. Am J Clin Nutr. 1995;61(2):334-40.

73. Cummings DE, Foster KE. Ghrelin-leptin tango in body-weight regulation. Gastroenterology. 2003;124(5):1532-5.

74. Ahima RS, Flier JS. Leptin. Annual review of physiology. 2000;62:413-37.

75. Pico C, Oliver P, Sanchez J, Palou A. Gastric leptin: a putative role in the short-term regulation of food intake. Br J Nutr. 2003;90(4):735-41.

76. Cummings DE, Purnell JQ, Frayo RS, Schmidova K, Wisse BE, Weigle DS. A preprandial rise in plasma ghrelin levels suggests a role in meal initiation in humans. Diabetes. 2001;50(8):1714-9.

77. Sanchez J, Cladera MM, Llopis M, Palou A, Pico C. The different satiating capacity of CHO and fats can be mediated by different effects on leptin and ghrelin systems. Behavioural brain research. 2010;213(2):183-8.

78. Nilsson AC, Ostman EM, Holst JJ, Bjorck IM. Including indigestible carbohydrates in the evening meal of healthy subjects improves glucose tolerance, lowers inflammatory markers, and increases satiety after a subsequent standardized breakfast. J Nutr. 2008;138(4):732-9.

79. Wachters-Hagedoorn RE, Priebe MG, Heimweg JA, Heiner AM, Englyst KN, Holst JJ, et al. The rate of intestinal glucose absorption is correlated with plasma glucose-dependent insulinotropic polypeptide concentrations in healthy men. J Nutr. 2006;136(6):1511-6.

80. Alvina M, Araya H. Rapid carbohydrate digestion rate produced lesser short-term satiety in obese preschool children. Eur J Clin Nutr. 2004;58(4):637-42. 
81. Keenan MJ, Zhou J, McCutcheon KL, Raggio AM, Bateman HG, Todd E, et al. Effects of resistant starch, a non-digestible fermentable fiber, on reducing body fat. Obesity (Silver Spring). 2006;14(9):1523-34.

82. Tappy L. Thermic effect of food and sympathetic nervous system activity in humans. Reprod Nutr Dev. 1996;36(4):391-7.

83. Westerterp-Plantenga MS. Satiety and $24 \mathrm{~h}$ diet-induced thermogenesis as related to macronutrient composition. Scandinavian Journal of Nutrition. 2000;44:104-7.

84. Trumbo P, Schlicker S, Yates AA, Poos M. Dietary reference intakes for energy, carbohydrate, fiber, fat, fatty acids, cholesterol, protein and amino acids. J Am Diet Assoc. 2002;102(11):1621-30.

85. Ruxton $\mathrm{CH}$, Gardner EJ, McNulty HM. Is sugar consumption detrimental to health? A review of the evidence 1995-2006. Crit Rev Food Sci Nutr. 2010;50(1):1-19.

86. EFSA Panel on Dietetic Products N, and Allergies (NDA). Scientific Opinion on Dietary Reference Values for carbohydrates and dietary fibre. . EFSA Journal 2010. 2010;8(3):1462 - 539.

87. Tappy L, Le KA. Metabolic effects of fructose and the worldwide increase in obesity. Physiol Rev. 2010;90(1):23-46.

88. Moran TH. Fructose and satiety. J Nutr. 2009;139(6):1253S-6S.

89. Dolan LC, Potter SM, Burdock GA. Evidence-based review on the effect of normal dietary consumption of fructose on development of hyperlipidemia and obesity in healthy, normal weight individuals. Crit Rev Food Sci Nutr. 2010;50(1):53-84.

90. Bowen J, Noakes M, Trenerry C, Clifton PM. Energy intake, ghrelin, and cholecystokinin after different carbohydrate and protein preloads in overweight men. J Clin Endocrinol Metab. 2006;91(4):1477-83.

91. Yang Q. Gain weight by "going diet?" Artificial sweeteners and the neurobiology of sugar cravings: Neuroscience 2010. Yale J Biol Med. 2010;83(2):101-8.

92. DiMeglio DP, Mattes RD. Liquid versus solid carbohydrate: effects on food intake and body weight. Int J Obes Relat Metab Disord. 2000;24(6):794-800.

93. Akhavan T, Luhovyy BL, Anderson GH. Effect of drinking compared with eating sugars or whey protein on short-term appetite and food intake. Int J Obes (Lond). 2010.

94. Tappy L, Randin JP, Felber JP, Chiolero R, Simonson DC, Jequier E, et al. Comparison of thermogenic effect of fructose and glucose in normal humans. Am J Physiol. 1986;250(6 Pt 1):E718-24.

95. Schwarz JM, Acheson KJ, Tappy L, Piolino V, Muller MJ, Felber JP, et al. Thermogenesis and fructose metabolism in humans. Am J Physiol. 1992;262(5 Pt 1):E591-8.

96. Brundin T, Wahren J. Whole body and splanchnic oxygen consumption and blood flow after oral ingestion of fructose or glucose. Am J Physiol. 1993;264(4 Pt 1):E504-13.

97. Sharief NN, Macdonald I. Differences in dietary-induced thermogenesis with various carbohydrates in normal and overweight men. Am J Clin Nutr. 1982;35(2):267-72.

98. Blaak EE, Saris WH. Postprandial thermogenesis and substrate utilization after ingestion of different dietary carbohydrates. Metabolism. 1996;45(10):1235-42.

99. Chao A, Grilo CM, White MA, Sinha R. Food cravings, food intake, and weight status in a communitybased sample. Eating behaviors. 2014;15(3):478-82.

100.Malik VS, Popkin BM, Bray GA, Despres JP, Hu FB. Sugar-sweetened beverages, obesity, type 2 diabetes mellitus, and cardiovascular disease risk. Circulation. 2010;121(11):1356-64.

101.Gibson S. Sugar-sweetened soft drinks and obesity: a systematic review of the evidence from observational studies and interventions. Nutr Res Rev. 2008;21(2):134-47.

102. Wolff E, Dansinger ML. Soft drinks and weight gain: how strong is the link? Medscape J Med. 2008;10(8):189.

103. Olsen NJ, Heitmann BL. Intake of calorically sweetened beverages and obesity. Obes Rev. 2009;10(1):6875.

104.Chen L, Appel LJ, Loria C, Lin PH, Champagne CM, Elmer PJ, et al. Reduction in consumption of sugarsweetened beverages is associated with weight loss: the PREMIER trial. Am J Clin Nutr. 2009;89(5):1299306.

105.Laville M, Nazare JA. Diabetes, insulin resistance and sugars. Obes Rev. 2009;10 Suppl 1:24-33. 
106.Yoshida M, McKeown NM, Rogers G, Meigs JB, Saltzman E, D'Agostino R, et al. Surrogate markers of insulin resistance are associated with consumption of sugar-sweetened drinks and fruit juice in middle and older-aged adults. J Nutr. 2007;137(9):2121-7.

107.Teff KL, Grudziak J, Townsend RR, Dunn TN, Grant RW, Adams SH, et al. Endocrine and metabolic effects of consuming fructose- and glucose-sweetened beverages with meals in obese men and women: influence of insulin resistance on plasma triglyceride responses. J Clin Endocrinol Metab. 2009;94(5):1562-9.

108. Malik VS, Popkin BM, Bray GA, Despres JP, Willett WC, Hu FB. Sugar Sweetened Beverages and Risk of Metabolic Syndrome and Type 2 Diabetes: A Meta-analysis. Diabetes Care. 2010.

109.Johnson RK, Appel LJ, Brands M, Howard BV, Lefevre M, Lustig RH, et al. Dietary sugars intake and cardiovascular health: a scientific statement from the American Heart Association. Circulation. 2009;120(11):1011-20.

110.Schaefer EJ, Gleason JA, Dansinger ML. Dietary fructose and glucose differentially affect lipid and glucose homeostasis. J Nutr. 2009;139(6):1257S-62S.

111.Sharma S, Roberts LS, Lustig RH, Fleming SE. Carbohydrate intake and cardiometabolic risk factors in high BMI African American children. Nutr Metab (Lond). 2010;7(1):10.

112. Welsh JA, Sharma A, Abramson JL, Vaccarino V, Gillespie C, Vos MB. Caloric sweetener consumption and dyslipidemia among US adults. Jama. 2010;303(15):1490-7.

113.Duffey KJ, Gordon-Larsen P, Steffen LM, Jacobs DR, Jr., Popkin BM. Drinking caloric beverages increases the risk of adverse cardiometabolic outcomes in the Coronary Artery Risk Development in Young Adults (CARDIA) Study. Am J Clin Nutr. 2010.

114.Yudkin J. Patterns and Trends in Carbohydrate Consumption and Their Relation to Disease. Proc Nutr Soc. 1964;23:149-62.

115.Johnson RJ, Segal MS, Sautin Y, Nakagawa T, Feig DI, Kang DH, et al. Potential role of sugar (fructose) in the epidemic of hypertension, obesity and the metabolic syndrome, diabetes, kidney disease, and cardiovascular disease. Am J Clin Nutr. 2007;86(4):899-906.

116.Bidwell AJ, Holmstrup ME, Doyle RP, Fairchild TJ. Assessment of endothelial function and blood metabolite status following acute ingestion of a fructose-containing beverage. Acta Physiol (Oxf). 2010;200(1):35-43.

117.Jalal DI, Smits G, Johnson RJ, Chonchol M. Increased fructose associates with elevated blood pressure. J Am Soc Nephrol. 2010;21(9):1543-9.

118.Stanhope KL, Havel PJ. Endocrine and metabolic effects of consuming beverages sweetened with fructose, glucose, sucrose, or high-fructose corn syrup. Am J Clin Nutr. 2008;88(6):1733S-7S.

119.Lindqvist A, Baelemans A, Erlanson-Albertsson C. Effects of sucrose, glucose and fructose on peripheral and central appetite signals. Regul Pept. 2008;150(1-3):26-32.

120. Melanson KJ, Angelopoulos TJ, Nguyen V, Zukley L, Lowndes J, Rippe JM. High-fructose corn syrup, energy intake, and appetite regulation. Am J Clin Nutr. 2008;88(6):1738S-44S.

121.Teff KL, Elliott SS, Tschop M, Kieffer TJ, Rader D, Heiman M, et al. Dietary fructose reduces circulating insulin and leptin, attenuates postprandial suppression of ghrelin, and increases triglycerides in women. J Clin Endocrinol Metab. 2004;89(6):2963-72.

122. Marckmann P, Raben A, Astrup A. Ad libitum intake of low-fat diets rich in either starchy foods or sucrose: effects on blood lipids, factor VII coagulant activity, and fibrinogen. Metabolism. 2000;49(6):731-5 


\section{CHAPTER 3}

\section{Weight loss maintenance in overweight subjects on ad libitum diets with high or low protein content and glycemic index: The DIOGENES trial 12-month results.}

Int J Obes (Lond). 2014 Dec;38(12):1511-7

Erik E.J.G. Aller

Thomas M. Larsen

Claus Holst

Anna Karin Lindroos

Anthony Kafatos

Andreas Pfeiffer

J. Alfredo Martinez

Teodora Handjieva-Darlenska

Marie Kunesova

Steen Stender

Wim H.M. Saris

Arne Astrup

Marleen A. van Baak 


\begin{abstract}
Background: A high dietary protein (P) content and low glycemic index (GI) have been suggested to be beneficial for weight management, but long-term studies are scarce. Objective: The DIOGENES randomized clinical trial investigated the effect of $\mathrm{P}$ and $\mathrm{GI}$ on weight loss maintenance in overweight or obese adults in 8 centers across Europe. This study reports the 1-year results in 2 of the centers that extended the intervention to 1 year.
\end{abstract}

Method: After an 8-week low calorie diet (LCD), 256 adults (BMI $>27 \mathrm{~kg} / \mathrm{m}^{2}$ ) were randomized to 5 ad libitum diets for 12 months: high P/low GI (HP/LGI), high P/high GI (HP/HGI), low P/low GI (LP/LGI), low P/high GI (LP/HGI) and a control diet. During the first 6 months foods were provided for free through a shop system, during the whole 12-month period subjects received guidance by a dietician. Primary outcome variable was the change in body weight over the 12-month intervention period.

Results: During the LCD period subjects lost $11.2(10.8,12.0) \mathrm{kg}$ (mean $(95 \% \mathrm{Cl})$ ). Average weight regain over the 12 -month intervention period was 3.9 ( $95 \% \mathrm{Cl} 3.0$ to 4.8 ) kg. Subjects on the HP diets regained less weight than subjects on the LP diets. The difference in weight regain after 1 year was $2.0(0.4,3.6) \mathrm{kg}(P=0.017)$ (completers analysis, $\mathrm{N}=139)$ or $2.8(1.4,4.1) \mathrm{kg}(P<0.001)$ (intention-to-treat analysis, $\mathrm{N}=256)$. No consistent effect of $\mathrm{GI}$ on weight regain was found. There were no clinically relevant differences in changes in cardiometabolic risk factors among diet groups.

Conclusion: A higher protein content of an ad libitum diet improves weight loss maintenance in overweight and obese adults over 12 months. 


\section{Introduction}

The primary prevention of weight gain in the whole population and the secondary prevention of weight regain in overweight and obese individuals that have lost weight is crucial to limit the adverse health consequences of overweight and obesity, but difficult to achieve.

Studies have shown that an increase in dietary protein content of an ad libitum diet results in more pronounced weight loss in overweight individuals $(1,2)$ and also contributes to better weight maintenance after weight loss (3-5), most likely because of the high satiating and thermogenic effect of proteins (6). Two recent meta-analyses support the beneficial effects of higher protein intake in weight management $(7,8)$. Most of the studies included in these meta-analyses were of limited duration, i.e. 6 months or shorter. Longer duration studies, so far, have found no evidence for better weight management with higher protein intake $(9,10)$.

Besides, the quantity and quality of dietary carbohydrates (e.g. the glycemic index (GI)) may be important in weight management. So far, there is little evidence for a role of dietary GI in body weight management (11), although a meta-regression analysis suggested that a reduction in dietary glycemic index under ad libitum or limited energy restriction conditions is associated with a modest body weight reduction (12). A more recent meta-analysis, however, concluded that there was no evidence for a beneficial effect of low Gl/GL diets on body weight in obesity (13).

To study the role of dietary protein content and GI in the prevention of weight regain after weight loss, the large-scale multi-centre DIOGENES dietary intervention study was initiated. The 6-months weight maintenance outcome of the study has been reported previously (14). Given the paucity of data from more long-term studies, we report here the 12-month results of the study in two of the study centers involved in the DIOGENES trial, Maastricht and Copenhagen on the primary outcome body weight and secondary outcomes body composition and cardiometabolic variables. In these two centers the intervention was continued for another 6 months, thus total intervention duration was 12 months. 


\section{Methods}

\section{Subjects}

Volunteer families were recruited in Copenhagen and Maastricht. Families (two-parent or single-parent) were eligible for participation if family members were generally healthy and if (1) at least one parent was overweight (BMI $>27 \mathrm{~kg} / \mathrm{m}^{2}$ ) and aged < $65 \mathrm{y}$; (2) at least one overweight child was between 8 and 15 y of age. The complete list of inand exclusion criteria has been published previously (15).

The study protocol and informed consent document were approved by the Medical Ethical Committees of Maastricht University and the University of Copenhagen. All subjects gave written informed consent before being enrolled into the study. The study was registered with ClinicalTrials.gov, number NCT00390637.

\section{Study design}

Only the adult family members who were overweight or obese at baseline were included in the current data analysis. The full study protocol has been described previously in detail (15) (Figure 1). In short, between screening and the first (pre LCD) test day, all adults enrolled into the study completed a 3-day weighed dietary record and collected 24-h urine (= baseline). On the test day subjects came to the research centers in the morning after an overnight fast. Weight, height, waist and hip circumference, abdominal sagittal diameter, body composition and blood pressure were measured. Fasting blood samples were collected. Subsequently, a 2-h oral glucose tolerance test (OGTT) was performed (15).

After these baseline measurements, subjects initiated an 8-week weight loss phase on a Low Calorie Diet (LCD) providing 3.4-3.7 MJ/d (800-880 kcal/d). If at least one of the parents of a two-parent family or the parent in a single-parent family had attained a weight loss of $\geq 8 \%$ of initial body weight after 8 weeks, the family was randomized into one of five diet groups, varying in protein content and glycemic index, for the 12-month dietary intervention period. The second test day took place on the last day of the LCD period (post LCD) and was similar to the pre LCD test day. However, no 3-day food record and no 24-h urine were collected at this time point.

After the post LCD test day families started the ad libitum diets. Laboratory shops were established to provide families with the majority of foods at no cost for 6 months. The shop system allowed us to more tightly control dietary intake of subjects $(16,17)$, in this case on a family level. During the second 6 months of the intervention, families had to purchase foods again in their own shops. Subjects came to the research centre at regular intervals to meet with a dietitian. At all visits body weight was monitored and 
dietary counseling was provided (15). At 4 weeks into the randomized phase subjects completed a 3-day weighed dietary record and collected 24-h urine to check compliance to the diets. After 6 and 12 months subjects returned to the research centre for the third and fourth test day (post intervention, week 26 and 52), which were the same as the previous test days including the 3-day weighed food diary and 24-h urine collection (15).

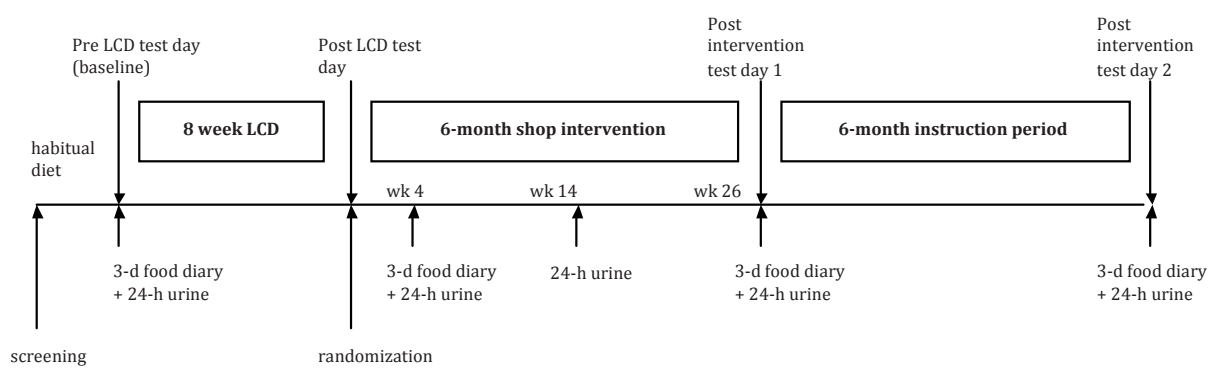

Figure 1: Study protocol

\section{Low calorie diet}

The low calorie diet we used was Modifast (Nutrition et Santé, France). Subjects were instructed to use 4 sachets per day (providing 3.4-3.7 MJ/d). Additional consumption of tomatoes $(200 \mathrm{~g} / \mathrm{d})$, cucumber $(125 \mathrm{~g} / \mathrm{d})$ and lettuce $(50 \mathrm{~g} / \mathrm{d})$ was allowed. In exceptional cases, particularly people with persistent hunger, 5 sachets per day could be taken.

\section{Randomization procedure}

Eligible families, in which at least one of the overweight/obese parents achieved the target weight loss ( $\geq 8 \%$ of body weight on pre LCD test day), were cluster-randomized to one of five diet groups using a simple block randomization procedure with stratification according to centre, the number of eligible parents in the family and the number of parents with $\mathrm{BMI}>34 \mathrm{~kg} / \mathrm{m}^{2}$. The randomization was performed with a web-based program (15).

For obvious reasons neither subjects nor dietitians or investigators could be blinded to the diet assignment. However, the investigators that performed the statistical analysis of this paper had not been in contact with the study participants. 


\section{Diet groups and dietary instruction}

Subjects were randomized into 5 diet groups: (1) low protein, low glycemic index (LP/LGI); (2) low protein, high glycemic index (LP/HGI); (3) high protein, low glycemic index (HP/LGI); (4) high protein, high glycemic index (HP/HGI); and (5) a diet according to national healthy eating recommendations (healthy) (18). All diets were low in fat (25$30 \%$ of energy from fat) and ad libitum, i.e. no energy restriction was imposed. We aimed at a protein consumption of $10-15 \%$ of total energy intake in the low protein groups and of $23-28 \%$ in the high protein groups. With respect to GI, a distinction was made between high and low Gl foods within each food group. The assignment of GI values to foods was performed as described by Aston et al. (19). Subjects in the low GI groups were advised to mainly consume the low GI foods within a food group, those in the high Gl groups the high Gl foods. The aim was to attain a 15-unit difference in glycemic index between the high and low GI groups. More detailed information on the diets and dietary counseling is provided in the paper by Moore et al. (18).

\section{Laboratory shops}

During the first 6 months adherence to dietary compositions was optimized by providing $>80 \%$ of all relevant foods for each of the different diet groups at no cost through a lab-based shop system as previously described in order to increase compliance $(16,17)$.

\section{Measurements}

Clinical examinations, oral glucose tolerance test (OGTT) and blood analysis

Body weight, waist circumference, body composition and blood pressure were measured as described previously (20). In each center the same equipment was used for all measurements. Subsequently, an OGTT was performed (20). The Matsuda index, a measure of insulin sensitivity in stimulated condition derived from fasting glucose and insulin and the glucose and insulin responses during the OGTT, was calculated (21). From the fasting glucose and insulin concentrations, the HOMA-IR and the HOMA-\%B (22), measures of (hepatic) insulin resistance and insulin secretion respectively, were calculated.

In fasting blood samples plasma adiponectin concentration and serum concentrations of glucose, insulin, total cholesterol, HDL cholesterol, triglycerides and CRP were measured as described previously $(20,23)$. Analysis of all samples was performed at the Department of Clinical Biochemistry, Gentofte University Hospital, Denmark. 


\section{Dietary records}

We provided all families with weighing scales (Soehnle 1208 Actuell or Salter Microtonic). Dietitians instructed the subjects on how to complete the 3-day food record on 3 consecutive days, including 2 weekdays and 1 weekend day. Participants were instructed to weigh all their foods and left-overs and provide brand names and details on cooking and processing where relevant. When weighing was not possible (e.g. when eating out), we instructed subjects to record the food intake in household measures (cups, glasses, table spoons, etc.). The food diaries were coded at each shop centre using the national Danish and Dutch food composition tables and GI values were added to the tables using a procedure described in more detail elsewhere (19).

\section{4-h Urine}

The completeness of the 24-h urinary collection was checked by recovery rate of Para amino benzoic acid (PABA) taken as tablets three times during the collection period. Urinary volume was recorded. Urinary nitrogen was determined by Dumas combustion methodology, using a VarioMax CN analyzer (Elementar, Hanau, Germany). Urinary C peptide was determined by a chemiluminescent immunometric assay (Immulite 2500, Siemens Healthcare). Urinary PABA was measured by spectrophotometry (Stasar, Gilford Instruments Laboratories, Oberlin, USA).

\section{Statistical analysis}

Results are presented as mean \pm SD, and estimates of effects as means and $95 \%$ confidence intervals. Differences between the five diet groups were analyzed by one-way ANOVA.

The effects of protein content and GI on weight and risk factor changes were analysed by a linear mixed model analysis with repeated measurements. In these analyses the 'healthy diet' group was not included. For weight changes, the model considered all available weight recordings (15 different time points) during the intervention. The analysis was adjusted for body mass index at randomization, total weight loss during the LCD and age as covariates. Diet group, center (Maastricht or Copenhagen), family structure (single parent, couple 1 parent randomized, couple both parents randomized) and gender were included as factors. The completers analysis involved all subjects that completed the 12-month intervention period $(N=139)$. The intention-to-treat analysis (ITT) involved all subjects that were randomized $(N=256)$ and assumed that the weight changes in participants who dropped out of the study followed the same course as in the completers from the moment they dropped out. Furthermore, a sensitivity analysis 
was performed with the same sample as the intention-to-treat analysis. In this analysis we assumed a 1-kg weight gain per month in participants that had dropped-out of the study from the moment they dropped out. Additional analyses were performed on changes in other anthropometric measures, body composition, and risk factors, which were measured at three time points (post LCD, 6 months (= wk 26) and 12 months (= wk 52). For these analyses we also used a mixed model with the same factors described above and with the post-LCD value of the tested variable as covariate. Self-reported dietary intake at 4, 26 and 52 weeks of the intervention was also analyzed by mixed model analysis.

If there was no statistically significant interaction between dietary GI and protein, only the main effects of protein content and GI were considered.

Significance was set at a $P$ value $<0.05$. Data were analyzed with SPSS version 16.0 .

\section{Results}

Out of 339 subjects (137 male, 202 female) attending the screening visit, 256 subjects (103 male, 153 female, age $42 \pm 6$ years) were randomized for the 12-month dietary intervention after the initial 8-week weight loss phase (Supplementary information Figure 1). Total weight loss during the LCD period for the randomized study population was $11.2 \pm 3.3 \mathrm{~kg}$ with no significant differences among diet groups. Other subject characteristics did not differ significantly either among groups (Supplementary information Table 1). 117 subjects dropped out during the intervention period (46\%), 51 during the first 6 months, 66 during the second 6 months. Drop-out rates were highest in the LP/HGI group (61\%) en lowest in the HP/LGI group (26\%). Post-LCD characteristics of these drop-outs did not differ among groups (data not shown). 


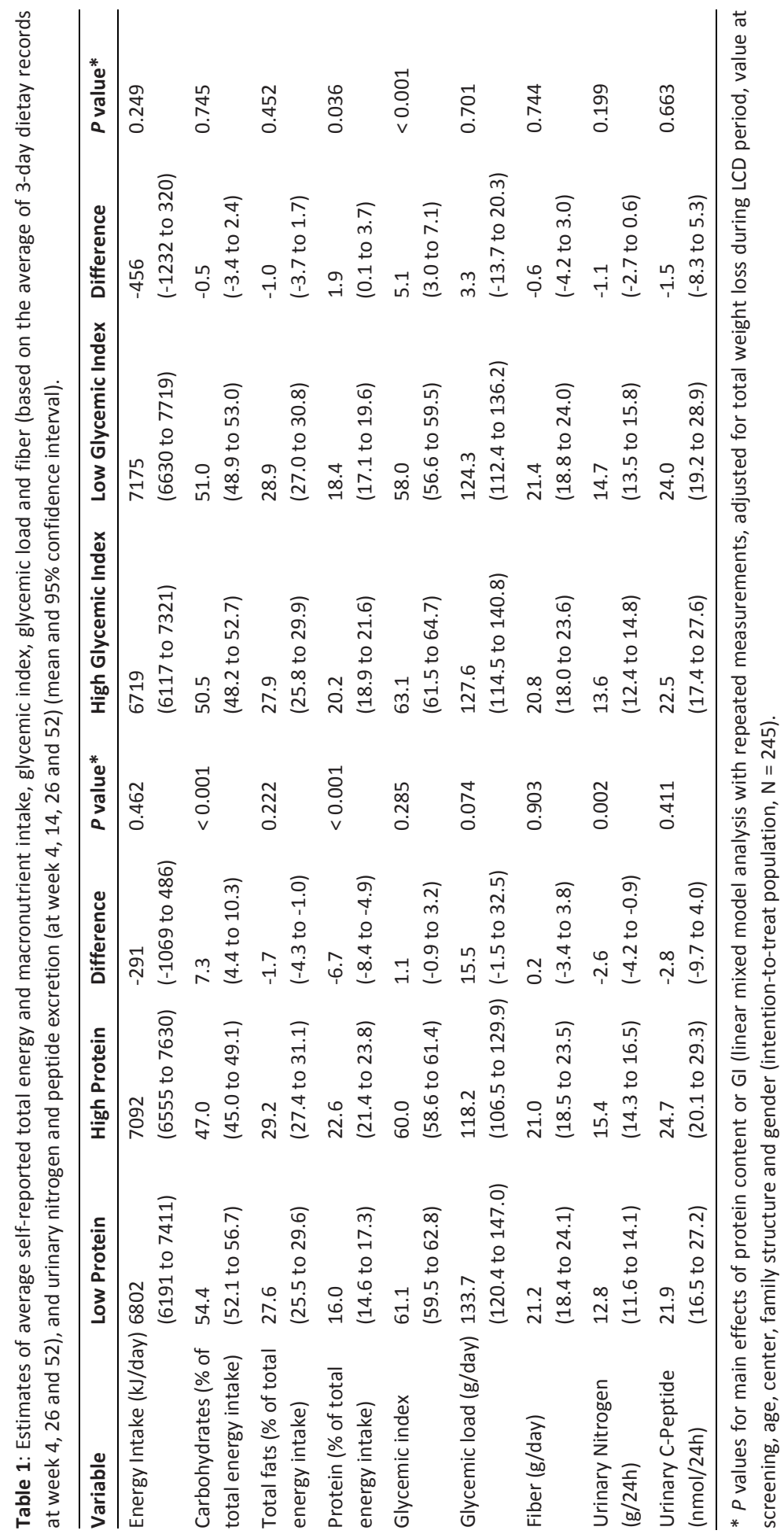




\section{Dietary intake}

Data on dietary intakes were obtained from 3-day dietary records. The habitual diet at screening had a carbohydrate content of $46 \% \pm 7 \%$, fat content of $35 \% \pm 6 \%$, and protein content of $16 \% \pm 4 \%$ of energy intake. Total energy intake was $9.6 \pm 2.9 \mathrm{MJ}$. Based on average 24-h urinary nitrogen excretion $(14.1 \mathrm{~g} / \mathrm{d})$, calculated from urines with a PABA recovery $\geq 85 \%$ (158 out of 240 ), habitual protein intake was $88 \mathrm{~g} / \mathrm{d}$. Habitual glycemic index (GI) was $63 \pm 5$ units and the glycemic load (GL) was $162 \pm 56 \mathrm{~g} / \mathrm{d}$. A description of the dietary intakes at different time points during the 12-month intervention period in the 5 groups is presented in Supplementary information table 2. Over the 12 months intervention, average protein intake, based on three 3-day dietary records and expressed as percent of total energy intake, was higher $(P<0.001)$ and carbohydrate intake was lower $(P<0.001)$ in the high protein compared to the low protein groups. Protein intake was higher in the high $\mathrm{Gl}$ compared to the low GI groups $(P=0.036)$ (table 1). Glycemic index was lower in the low $\mathrm{Gl}$ compared to the high $\mathrm{Gl}$ groups $(P<0.001)$. There were no statistically significant differences in fat and fiber intake between groups. Reported dietary intakes were similar after 6 and 12 months of intervention in all groups.

Average urinary nitrogen excretion in the four $24 \mathrm{~h}$ urine collections, a marker for protein intake, was higher in the high protein groups compared to the low protein group $(P$ $=0.002$ ) (table 1). In accordance, the change in plasma urea during the intervention differed between the high protein groups and the low protein groups $(P=0.003)$ (table 4). When only $24 \mathrm{~h}$ urines with a PABA recovery $\geq 85 \%$ were taken into account, urinary $\mathrm{N}$ excretion was $13.7 \mathrm{~g} / \mathrm{d}$ in the low protein group and $16.9 \mathrm{~g} / \mathrm{d}$ in the high protein group, translating into a dietary protein intake of $86 \mathrm{~g} / \mathrm{d}$ in the low protein group and $106 \mathrm{~g} / \mathrm{d}$ in the high protein group.

The reported difference in protein intake between the LP and HP groups (7 energy\%) and the difference in GI between the LGI and HGI groups (5 units) were smaller than intended (10 energy\% and 15 units respectively). 


\section{Changes in body weight}

Average weight regain was $3.9(95 \% \mathrm{Cl} 3.0$ to 4.8$) \mathrm{kg}$ in the completers. Weight regain in the 5 diet groups after the 12-month intervention is shown in Supplementary information figure 2. There was no significant interaction between protein content and $\mathrm{Gl}$ of the diet $(P=0.871)$, therefore the main effects of protein content and GI were analysed. Weight regain was more pronounced in the low protein compared to the high protein groups in the completers (difference $2.0(95 \% \mathrm{Cl} 0.4$ to 3.6$) \mathrm{kg}, P=0.017$ ). The intention-to-treat analysis and the sensitivity analysis were in agreement with a better weight loss maintenance on the HP compared to the LP diets (Table 2). High GI groups showed 2.1 ( 0.5 to 3.8 ) $\mathrm{kg}$ less weight regain than low $\mathrm{Gl}$ groups $(P=0.013)$. According to the intention-to-treat and sensitivity analyses, however, there was no significant effect of $\mathrm{Gl}$ on weight regain (Table 2 and Figure 2). 


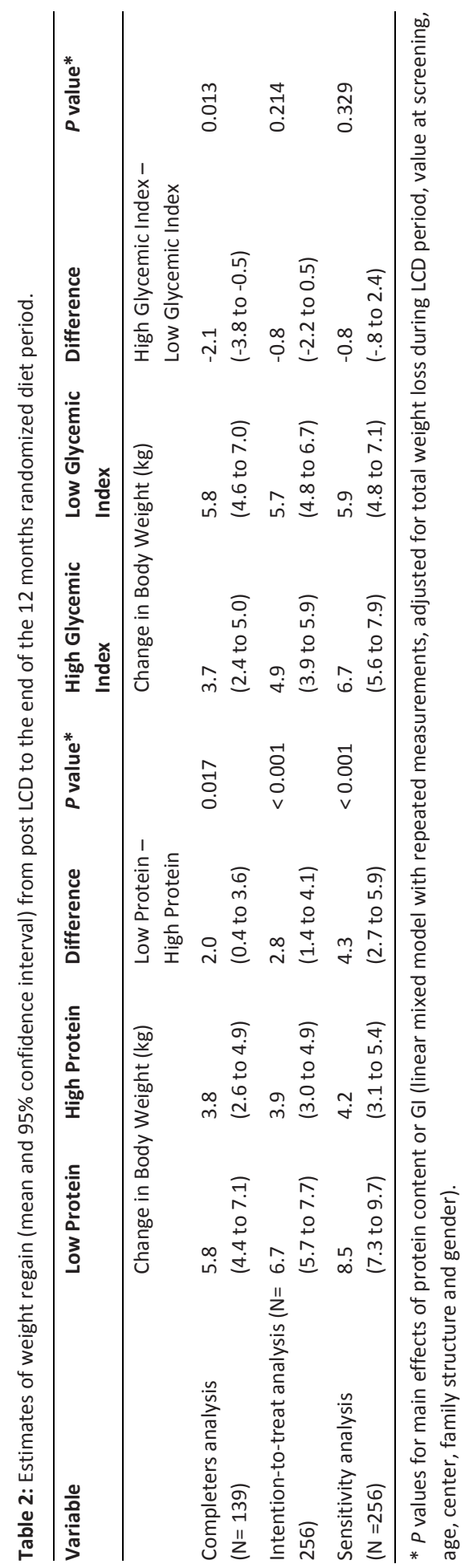


a

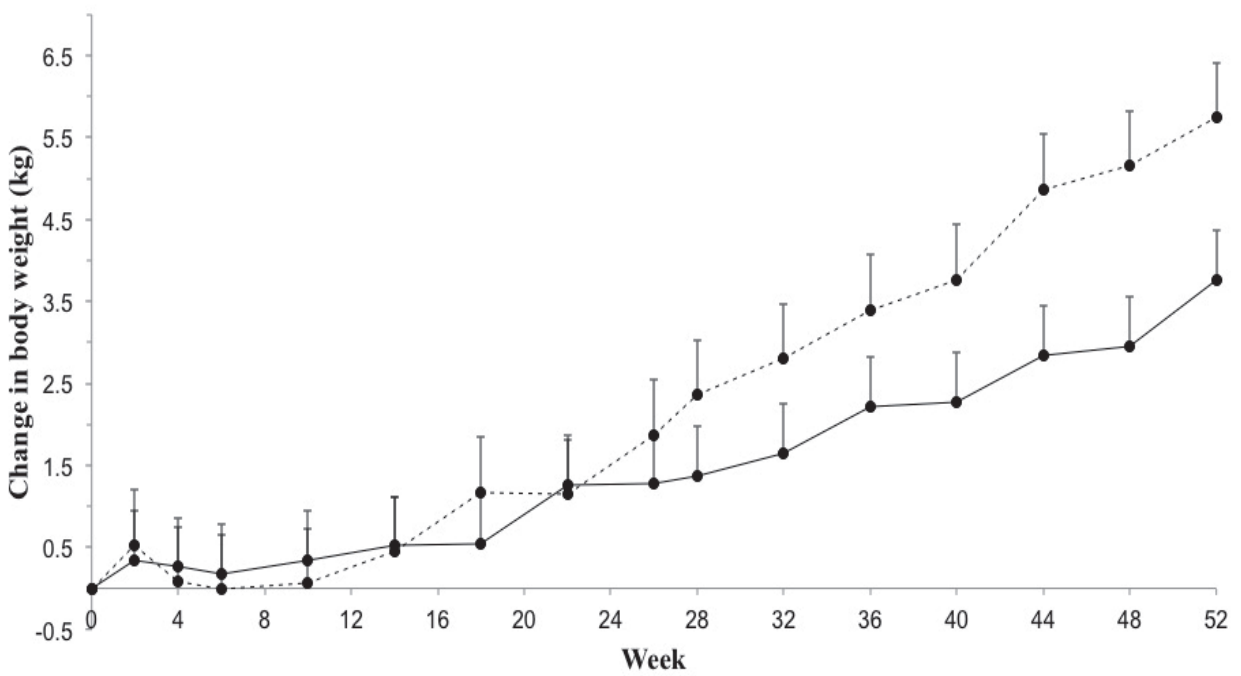

- Completers LP (n=47) $\quad-$ - Completers HP (n=65)

b

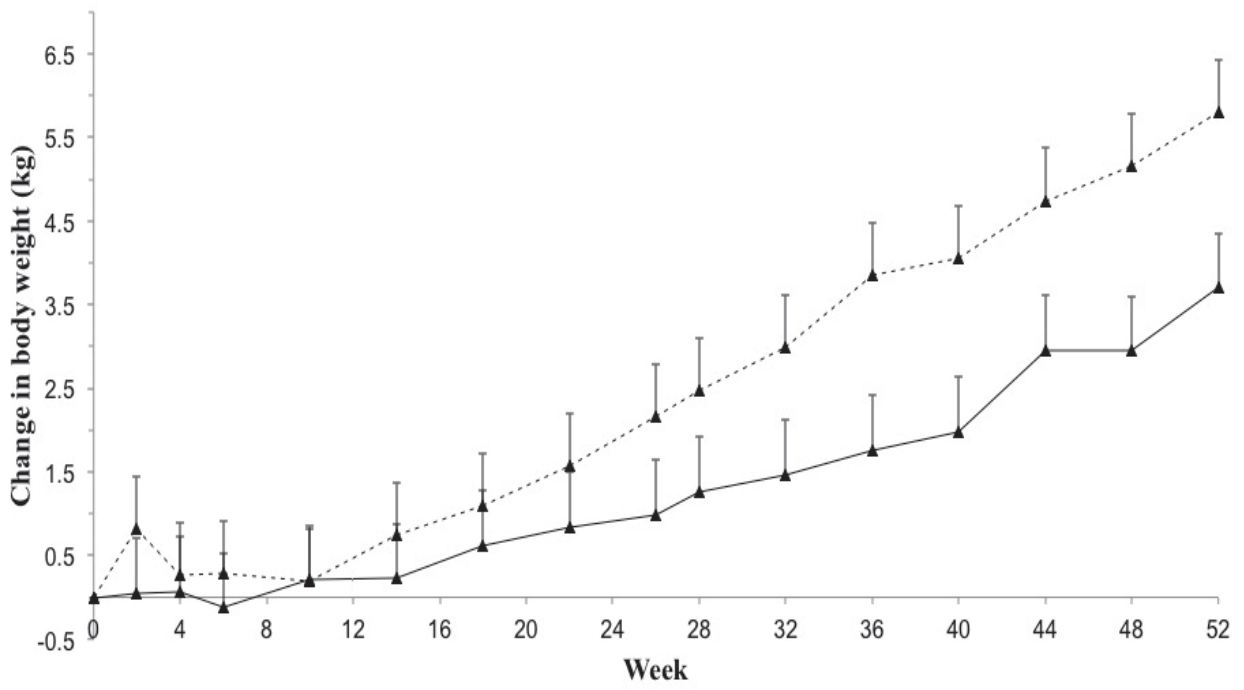

* Completers LGI $(\mathrm{n}=63) \quad \star$ Completers HGI $(\mathrm{n}=49)$

Figure 2: Body weight change in the completers during the 12-month randomized dietary intervention in the HP and LP groups (a) and in the HGI and LGI groups (b) (mean \pm s.e.) 


\section{Changes in body composition}

Over the 12-month intervention, the subjects in the high protein groups showed more favorable changes in other anthropometric variables and body composition than those in the low protein groups, whereas no differences were found between the high and low GI groups (Table 3 ). The high protein groups increased less in fat mass (difference 1.6 (0 to 3.1$) \mathrm{kg} ; P=0.043)$ and sagittal diameter $(0.9(0.2$ to 1.5$) \mathrm{cm} ; P=0.012) \mathrm{com}$ pared to the low protein groups. In the low protein group $49 \%$ of the weight regain was fat free mass, in the high protein group this was $61 \%(P=0.378)$.

Table 3: Estimates of changes in body composition (mean and $95 \%$ confidence interval) from post-LCD to the end of the 12 months randomized diet period.

\begin{tabular}{|c|c|c|c|c|c|c|c|c|}
\hline Vari & ny & $\begin{array}{l}\text { High P } \\
\text { tein }\end{array}$ & Dif & $P$ & $\begin{array}{l}\text { High Gly- } \\
\text { cemic Index }\end{array}$ & $\begin{array}{l}\text { lyce- } \\
\text { dex }\end{array}$ & $\mathrm{Di}$ & גe* \\
\hline $\begin{array}{l}\text { Fat-free mass } \\
(\mathrm{kg})\end{array}$ & $\begin{array}{l}3.3 \\
(2.6 \text { to } 4.0)\end{array}$ & $\begin{array}{l}2.8 \\
(2.2 \text { to } 3.5)\end{array}$ & $\begin{array}{l}0.5 \\
(-0.4 \text { to } 1.3)\end{array}$ & & $\begin{array}{l}2.9 \\
\text { ( } 2.2 \text { to } 3.6 \text { ) }\end{array}$ & $\begin{array}{l}3.2 \\
\text { ( } 2.5 \text { to } 3.9 \text { ) }\end{array}$ & $\begin{array}{l}-0.3 \\
(-1.1 \text { to } 0.6)\end{array}$ & \\
\hline Cat mos lka & $\begin{array}{l}3.4 \\
(2.2 \text { to } 4.6)\end{array}$ & $\begin{array}{l}1.8 \\
(0.7 \text { to } 3.0)\end{array}$ & $\begin{array}{l}1.6 \\
(0.1 \text { to } 3.1)\end{array}$ & & $\begin{array}{l}2.3 \\
(1.0 \text { to } 3.5)\end{array}$ & $\begin{array}{l}3.0 \\
(1.8 \text { to } 4.1)\end{array}$ & $\begin{array}{l}-0.7 \\
(-2.2 \text { to } 0.8)\end{array}$ & \\
\hline $\begin{array}{l}\text { Waist circumfe } \\
\text { ence }(\mathrm{cm})\end{array}$ & $\begin{array}{l}-6.4 \\
(4.4 \text { to } 8.4)\end{array}$ & $\begin{array}{l}4.6 \\
(2.7 \text { to } 6.4)\end{array}$ & $\begin{array}{l}1.8 \\
(-0.7 \text { to } 4.3)\end{array}$ & & $\begin{array}{l}4.6 \\
\text { (2.6 to } 6.6)\end{array}$ & $\begin{array}{l}6.3 \\
(4.5 \text { to } 8.2 \text { ) }\end{array}$ & $\begin{array}{l}-1.7 \\
(-4.2 \text { to } 0.8)\end{array}$ & \\
\hline $\begin{array}{l}\text { Hip circumfer- } \\
\text { ence }(\mathrm{cm})\end{array}$ & $\begin{array}{l}4.4 \\
\text { (2.8 to } 5.9 \text { ) }\end{array}$ & $\begin{array}{l}2.7 \\
(1.3 \text { to } 4.1)\end{array}$ & $\begin{array}{l}1.7 \\
(-0.3 \text { to } 3.5)\end{array}$ & & $\begin{array}{l}3.3 \\
(1.8 \text { to } 4.8)\end{array}$ & $\begin{array}{l}3.8 \\
(2.3 \text { to } 5.2)\end{array}$ & $\begin{array}{l}-0.5 \\
(-2.4 \text { to } 1.4)\end{array}$ & 0.615 \\
\hline $\begin{array}{l}\text { Sagittal diamete } \\
(\mathrm{cm})\end{array}$ & $\begin{array}{l}1.7 \\
(1.2 \text { to } 2.3)\end{array}$ & $\begin{array}{l}0.9 \\
(0.4 \text { to } 1.4)\end{array}$ & $\begin{array}{l}0.8 \\
(0.2 \text { to } 1.5)\end{array}$ & 0.012 & $\begin{array}{l}1.3 \\
\text { (0.8 to } 1.8 \text { ) }\end{array}$ & $\begin{array}{l}1.3 \\
\text { (0.8 to } 1.8)\end{array}$ & $\begin{array}{l}0.0 \\
(-0.7 \text { to } 0.7)\end{array}$ & 0.982 \\
\hline
\end{tabular}

$* P$ value for main effect of protein content or $\mathrm{Gl}$ (linear mixed model analysis (intention-to-treat population), adjusted for total weight loss during LCD period, value at post-LCD, age, diet group, center, family structure and gender).

\section{Changes in metabolic and cardiovascular risk factors}

After 12 months, triglycerides, CRP, fasting insulin, 2-h glucose and insulin, HOMA-IR and HOMA-\%B were significantly lower, whereas Matsuda index, adiponectin, HDL, LDL, total cholesterol and fructosamine were significantly higher than at baseline (pre LCD). Blood pressure and fasting glucose did not differ (data not shown). Table 4 shows the changes in cardiovascular and metabolic risk factors over the 12-month intervention period (from post-LCD to month 12) and the differences between diet groups. Only the increase in fasting plasma glucose was less pronounced $(0.2(0.0$ to 0.3$) \mathrm{mmol} / \mathrm{L} ; P=$ 0.011 ) in the high protein compared to the low protein group. For LDL cholesterol changes a statistically significant interaction between protein content and GI was found $(P=0.011)$, which was due to an increase in LDL cholesterol in the HGI group on a LP diet and a decrease in the HGI group on the HP diet. Plasma urea concentration increased more in the HP than in the LP groups $(P=0.001)$. We found no differences in 
the other variables when comparing the protein or Gl groups. If the change in body weight during the intervention was added to the model, HDL increased significantly more in the HP than in the LP groups $(P=0.033)$.

Table 4: Estimates of changes in metabolic and cardiovascular risk factors (mean and $95 \%$ confidence interval) from post-LCD to the end of the 12 months randomized diet period.

\begin{tabular}{|c|c|c|c|c|c|c|c|c|}
\hline Variable & Low Protein & High Protein & Difference & $P$ value* & $\begin{array}{l}\text { High Glyce- } \\
\text { mic Index }\end{array}$ & $\begin{array}{l}\text { Low Glyce- } \\
\text { mic Index }\end{array}$ & Difference & $P$ value* \\
\hline $\begin{array}{l}\text { Systolic blood } \\
\text { pressure } \\
(\mathrm{mmHg})\end{array}$ & $\begin{array}{l}9.25 \\
(6.17 \text { to } \\
12.32)\end{array}$ & $\begin{array}{l}6.96 \\
(4.25 \text { to } \\
9.67)\end{array}$ & $\begin{array}{l}2.29 \\
(-1.50 \text { to } \\
6.09)\end{array}$ & 0.235 & $\begin{array}{l}8.06 \\
(5.10 \text { to } \\
11.02)\end{array}$ & $\begin{array}{l}8.16 \\
(5.35 \text { to } \\
10.97)\end{array}$ & $\begin{array}{l}-0.10 \\
(-3.87 \text { to } \\
3.67)\end{array}$ & 0.959 \\
\hline $\begin{array}{l}\text { Diastolic } \\
\text { blood pres- } \\
\text { sure (mmHg) }\end{array}$ & $\begin{array}{l}7.11 \\
\text { (5.08 to } \\
9.15)\end{array}$ & $\begin{array}{l}5.52 \\
(3.72 \text { to } \\
7.32)\end{array}$ & $\begin{array}{l}1.60 \\
(-0.92 \text { to } \\
4.12)\end{array}$ & 0.212 & $\begin{array}{l}6.01 \\
\text { (4.04 to } \\
7.97)\end{array}$ & $\begin{array}{l}6.63 \\
(4.75 \text { to } \\
8.50)\end{array}$ & $\begin{array}{l}-0.62 \\
(-3.13 \text { to } \\
1.88)\end{array}$ & 0.626 \\
\hline $\begin{array}{l}\text { Total choles- } \\
\text { terol } \\
(\mathrm{mmol} / \mathrm{L})\end{array}$ & $\begin{array}{l}1.37 \\
(1.16 \text { to } \\
1.59)\end{array}$ & $\begin{array}{l}1.35 \\
(1.15 \text { to } \\
1.54)\end{array}$ & $\begin{array}{l}0.03 \\
(-0.24 \text { to } \\
0.29)\end{array}$ & 0.854 & $\begin{array}{l}1.38 \\
(1.17 \text { to } \\
1.59)\end{array}$ & $\begin{array}{l}1.34 \\
(1.13 \text { to } \\
1.54)\end{array}$ & $\begin{array}{l}0.04 \\
(-0.23 \text { to } \\
0.31)\end{array}$ & 0.778 \\
\hline $\mathrm{HDL}(\mathrm{mmol} / \mathrm{L})$ & $\begin{array}{l}0.21 \\
(0.14 \text { to } \\
0.27)\end{array}$ & $\begin{array}{l}0.27 \\
(0.21 \text { to } \\
0.33)\end{array}$ & $\begin{array}{l}-0.06 \\
(-0.15 \text { to } \\
0.02)\end{array}$ & 0.125 & $\begin{array}{l}0.22 \\
(0.15 \text { to } \\
0.28)\end{array}$ & $\begin{array}{l}0.26 \\
(0.19 \text { to } \\
0.32)\end{array}$ & $\begin{array}{l}-0.04 \\
(-0.13 \text { to } \\
0.04)\end{array}$ & 0.336 \\
\hline $\mathrm{LDL}(\mathrm{mmol} / \mathrm{L})$ & $\begin{array}{l}0.96 \\
(0.77 \text { to } \\
1.15)\end{array}$ & $\begin{array}{l}0.91 \\
(0.73 \text { to } \\
1.08)\end{array}$ & $\begin{array}{l}0.05 \\
(-0.19 \text { to } \\
0.29)\end{array}$ & 0.664 & $\begin{array}{l}0.94 \\
(0.75 \text { to } \\
1.12)\end{array}$ & $\begin{array}{l}0.93 \\
(0.75 \text { to } \\
1.11)\end{array}$ & $\begin{array}{l}0.01 \\
(-0.23 \text { to } \\
0.25)\end{array}$ & 0.934 \\
\hline $\begin{array}{l}\text { Triglycerides } \\
\text { (mmol/L) }\end{array}$ & $\begin{array}{l}0.41 \\
(0.27 \text { to } \\
0.56)\end{array}$ & $\begin{array}{l}0.37 \\
(0.24 \text { to } \\
0.50)\end{array}$ & $\begin{array}{l}0.04 \\
(-0.13 \text { to } \\
0.23)\end{array}$ & 0.616 & $\begin{array}{l}0.40 \\
(0.26 \text { to } \\
0.54)\end{array}$ & $\begin{array}{l}0.38 \\
(0.24 \text { to } \\
0.51)\end{array}$ & $\begin{array}{l}0.02 \\
(-0.15 \text { to } \\
0.20)\end{array}$ & 0.779 \\
\hline $\begin{array}{l}\text { Adiponectin } \\
(\mu \mathrm{g} / \mathrm{mL})\end{array}$ & $\begin{array}{l}2.77 \\
(1.74 \text { to } \\
3.79)\end{array}$ & $\begin{array}{l}3.81 \\
(2.90 \text { to } \\
4.73)\end{array}$ & $\begin{array}{l}-1.05 \\
(-2.32 \text { to } \\
0.23)\end{array}$ & 0.107 & $\begin{array}{l}3.34 \\
(2.33 \text { to } \\
4.34)\end{array}$ & $\begin{array}{l}3.24 \\
(2.30 \text { to } \\
4.18)\end{array}$ & $\begin{array}{l}0.09 \\
(-1.18 \text { to } \\
1.37)\end{array}$ & 0.885 \\
\hline CRP (mg/L) & $\begin{array}{l}0.05 \\
(-0.51 \text { to } \\
0.61)\end{array}$ & $\begin{array}{l}0.00 \\
(-0.52 \text { to } \\
0.51)\end{array}$ & $\begin{array}{l}0.05 \\
(-0.64 \text { to } \\
0.75)\end{array}$ & 0.870 & $\begin{array}{l}0.06 \\
(-0.48 \text { to } \\
0.59)\end{array}$ & $\begin{array}{l}-0.01 \\
(-0.54 \text { to } \\
0.52)\end{array}$ & $\begin{array}{l}0.06 \\
(-0.63 \text { to } \\
0.76)\end{array}$ & 0.856 \\
\hline $\begin{array}{l}\text { Fasting } \\
\text { glucose } \\
\text { (mmol/L) }\end{array}$ & $\begin{array}{l}0.57 \\
(0.45 \text { to } \\
0.68)\end{array}$ & $\begin{array}{l}0.38 \\
(0.27 \text { to } \\
0.48)\end{array}$ & $\begin{array}{l}0.19 \\
(0.04 \text { to } \\
0.33)\end{array}$ & 0.011 & $\begin{array}{l}0.42 \\
(0.30 \text { to } \\
0.53)\end{array}$ & $\begin{array}{l}0.53 \\
(0.42 \text { to } \\
0.63)\end{array}$ & $\begin{array}{l}-0.11 \\
(-0.26 \text { to } \\
0.03)\end{array}$ & 0.134 \\
\hline $\begin{array}{l}\text { Fasting } \\
\text { insulin } \\
\text { (mIU/L) }\end{array}$ & $\begin{array}{l}2.70 \\
(1.58 \text { to } \\
3.81)\end{array}$ & $\begin{array}{l}1.76 \\
(0.77 \text { to } \\
2.76)\end{array}$ & $\begin{array}{l}0.93 \\
(-0.46 \text { to } \\
2.32)\end{array}$ & 0.188 & $\begin{array}{l}2.56 \\
(1.45 \text { to } \\
3.66)\end{array}$ & $\begin{array}{l}1.90 \\
(0.89 \text { to } \\
2.92)\end{array}$ & $\begin{array}{l}0.65 \\
(-0.74 \text { to } \\
2.05)\end{array}$ & 0.357 \\
\hline $\begin{array}{l}\text { Fructosamine } \\
(\mu \mathrm{mol} / \mathrm{L})\end{array}$ & $\begin{array}{l}9.60 \\
(4.61 \text { to } \\
14.59)\end{array}$ & $\begin{array}{l}11.48 \\
(6.89 \text { to } \\
16.08)\end{array}$ & $\begin{array}{l}-1.89 \\
(-8.09 \text { to } \\
4.31)\end{array}$ & 0.550 & $\begin{array}{l}9.46 \\
(4.58 \text { to } \\
14.35)\end{array}$ & $\begin{array}{l}11.62 \\
\text { (6.87 to } \\
16.38)\end{array}$ & $\begin{array}{l}-2.16 \\
(-8.42 \text { to } \\
4.10)\end{array}$ & 0.498 \\
\hline $\begin{array}{l}\text { 2h Glucose } \\
\text { (mmol/L) }\end{array}$ & $\begin{array}{l}-0.87 \\
(-1.29 \text { to }- \\
0.77)\end{array}$ & $\begin{array}{l}-1.29 \\
(-1.69 \text { to }- \\
0.89)\end{array}$ & $\begin{array}{l}0.42 \\
(-0.11 \text { to } \\
0.96)\end{array}$ & 0.119 & $\begin{array}{l}-1.14 \\
(-1.56 \text { to }- \\
0.73)\end{array}$ & $\begin{array}{l}-1.01 \\
(-1.42 \text { to }- \\
0.61)\end{array}$ & $\begin{array}{l}-0.13 \\
(-0.66 \text { to } \\
0.40)\end{array}$ & 0.623 \\
\hline $\begin{array}{l}\text { Urea } \\
\text { (mmol/L) }\end{array}$ & $\begin{array}{l}4.06 \\
\text { (3.78 to }\end{array}$ & $\begin{array}{l}4.66 \\
\text { (4.41 to }\end{array}$ & $\begin{array}{l}-0.59 \\
(-0.95 \text { to }-\end{array}$ & 0.001 & $\begin{array}{l}4.30 \\
\text { (4.02 to }\end{array}$ & $\begin{array}{l}4.42 \\
\text { (4.16 to }\end{array}$ & $\begin{array}{l}-0.12 \\
(-0.47 \text { to }\end{array}$ & 0.493 \\
\hline
\end{tabular}




\begin{tabular}{|c|c|c|c|c|c|c|c|c|}
\hline Variable & Low Protein & High Protein & in Difference & $P$ value* & $\begin{array}{l}\text { High Glyce- } \\
\text { mic Index }\end{array}$ & $\begin{array}{l}\text { Low Glyce- } \\
\text { mic Index }\end{array}$ & Difference & $P$ value* \\
\hline & $4.35)$ & $4.90)$ & $0.24)$ & & 4.57) & 4.68) & $0.23)$ & \\
\hline $\begin{array}{l}\text { HOMA-IR } \\
\text { index }\end{array}$ & $\begin{array}{l}0.93 \\
(0.60 \text { to } \\
1.25)\end{array}$ & $\begin{array}{l}0.59 \\
(0.30 \text { to } \\
0.88)\end{array}$ & $\begin{array}{l}0.33 \\
(-0.07 \text { to } \\
0.74)\end{array}$ & 0.107 & $\begin{array}{l}0.81 \\
(0.49 \text { to } \\
1.13)\end{array}$ & $\begin{array}{l}0.71 \\
(0.41 \text { to } \\
1.00)\end{array}$ & $\begin{array}{l}0.105 \\
(-0.30 \text { to } \\
0.51)\end{array}$ & 0.612 \\
\hline $\begin{array}{l}\text { HOMA-\%B } \\
\text { index }\end{array}$ & $\begin{array}{l}-19.13 \\
(-47.91 \text { to } \\
9.66)\end{array}$ & $\begin{array}{l}-24.14 \\
(-51.19 \text { to } \\
2.90)\end{array}$ & $\begin{array}{l}5.02 \\
(-30.41 \text { to } \\
40.44)\end{array}$ & 0.780 & $\begin{array}{l}-7.49 \\
(-35.91 \text { to } \\
20.93)\end{array}$ & $\begin{array}{l}-35.78 \\
(-63.63 \text { to }- \\
7.94)\end{array}$ & $\begin{array}{l}28.30 \\
(-7.77 \text { to } \\
64.36)\end{array}$ & 0.123 \\
\hline $\begin{array}{l}\text { Matsuda } \\
\text { index }\end{array}$ & $\begin{array}{l}-1.57 \\
(-2.62 \text { to }- \\
0.52)\end{array}$ & $\begin{array}{l}-0.71 \\
(-1.68 \text { to } \\
0.27)\end{array}$ & $\begin{array}{l}-0.86 \\
(-2.17 \text { to } \\
0.44)\end{array}$ & 0.192 & $\begin{array}{l}-0.73 \\
(-1.78 \text { to } \\
0.32)\end{array}$ & $\begin{array}{l}-1.55 \\
(-2.53 \text { to }- \\
0.56)\end{array}$ & $\begin{array}{l}0.81 \\
(-0.50 \text { to } \\
2.13)\end{array}$ & 0.223 \\
\hline
\end{tabular}

$* P$ value for main effects of protein content or GI (linear mixed model analysis with repeated measurements (intention-to-treat population), adjusted for total weight loss during LCD period, value at post-LCD, age, diet group, center, family structure and gender).

\section{Discussion}

The findings of the DIOGENES in the two highly-controlled shop-based diet intervention centers indicate that an increase in dietary protein content (approximately $7 \%$ of total energy intake) in the context of an ad libitum diet reduces weight regain over 12 months after weight loss induced by an energy-restricted diet. A modest increase in the glycemic index of the diet (approximately 5 units) was associated with less weight regain over 12 months in the completers analysis, but not in the intention-to-treat or sensitivity analyses, making this a less reliable outcome.

A major limitation of our study is obviously the high drop-out rate during the intervention. This may be inherent to the type of trial, where part of the motivation of subjects to participate is likely to have been the provision of free foods during the first 6 months of the intervention. However, the effects of protein intake appear to be robust in all analyses, in- or excluding drop-outs. The HP/LGI diet group had the lowest dropout rate, suggesting this may have been the most acceptable and/or palatable diet for the participants.

The reliability of dietary records with respect to macronutrient composition and GI of the diet can be questioned, since misreporting is a major issue (24). However, the differences in urinary nitrogen excretion and plasma urea concentration between the high and low protein diet groups confirm the difference in protein intake from dietary records between these groups in a qualitative sense. It has been suggested that serum fructosamine is a marker of glycemic load and dietary sugar intake in non-diabetic subjects $(25,26)$. In this study we were unable to demonstrate differences in fructosamine concentrations between groups with high and low Gl or glycemic load. Moreover, urinary C-peptide excretion, which has been shown to reflect glycemic index of diets with identical macronutrient composition (27), did not differ between diet groups in our 
study. Thus, we are not able to objectively verify the reported difference in Gl between the groups.

The 12 months effect of dietary protein content is in line with the previously reported 6 months results in all DIOGENES centers (14). Our data also confirm previous studies that showed better weight loss maintenance with ad libitum diets with a higher protein content by providing protein supplements $(3,4,28)$. The LP groups had a dietary protein content that was similar to the habitual, baseline protein content (approximately 16\%), which shows that subjects in the LP groups did not reduce their protein intake to the target level of 10-15\% of energy intake. The HP groups, on the other hand, increased their protein intake to the intended level. A weight loss study by Sacks et al. with similar group assignment (15 vs $25 \%$ of total energy from proteins in the context of an energy-restricted diet) attained a self-reported protein intake difference of $4 \%$ of total energy at 6 months and of 1 energy\% at 24 months with no significant differences in weight loss between groups (10). Although the study designs were not completely comparable, a better adherence in our trial may have contributed to our finding of better weight maintenance on the high protein diets. In addition, it has been suggested that high-protein diets may stimulate maintenance or accretion of muscle mass, thereby increasing energy expenditure and improving metabolic profile (6). Our data are in agreement with this, since changes in fat-free mass were not significantly different in the LP and HP groups despite the significantly lower body mass increase in the HP groups. However, the between-group difference in fatfree mass change as percentage of body weight change was not statistically significant, which may be due to the relatively small number of subjects in whom body composition data were available.

A higher GI diet was associated with better weight maintenance in our study, although this was not supported by the intention-to-treat and sensitivity analyses and thus may have been a chance finding. Two meta-analyses came to different conclusions about the effect of $\mathrm{GI}$ on body weight $(12,13)$. The 6 -months analysis of the whole DIOGENES trial has indicated less weight was regained in the groups consuming the LGI diet (14). The reasons for these inconsistent findings are not directly clear. They are not due to smaller self-reported differences in dietary $\mathrm{Gl}$ in the two shop centers than in the other centers, which were very similar ( 5 vs 5 units). The HGI diet was accompanied by a significantly higher protein intake in the two shop centers and this may have confounded the Gl effect, although the interaction between GI and protein content was not significant. It is also possible that the foods that contributed to the GI of the diet were different in the two centers in this analysis from those in the whole DIOGENES study population.

After 12 months most cardiovascular risk factors still showed significant improvements compared to baseline (pre LCD), except for total and LDL cholesterol. Diet composition hardly influenced these changes, only fasting glucose concentration increased significantly more in the LP than HP groups. The clinical relevance of this finding is not clear, since fasting plasma glucose levels remained in the normal range on both diets. In 
addition, measures of insulin resistance, C-peptide excretion and plasma fructosamine concentration were not different between protein groups. Thus, in this population of relatively healthy overweight adults an increase in dietary protein content, which improves weight loss maintenance, was not associated with negative effects on the risk factor profile.

In conclusion, a moderate increase in dietary protein content helps to reduce weight regain after weight loss on an ad libitum diet over a 12-month period, without untoward effects on risk factors for cardiovascular disease and type 2 diabetes. The role of $\mathrm{Gl}$ in prevention of weight regain remains uncertain.

\section{Acknowledgements}

We gratefully acknowledge all food companies for their contributions of foods to the laboratory shops. The DIOGENES trial was funded by the European Commission, contract no. FP6-2005-513946.

\section{Conflict of interest}

Dr Astrup is currently member of advisory boards for McCain Foods, USA, Global Dairy Platform, USA, JennyCraig, USA, and McDonald's, USA and has received funding for other studies from about 100 food companies covering all food groups. Dr Saris is corporate scientist human nutrition for DSM, The Netherlands, and received research grants and food donations from several food companies. Drs Aller, Larsen, Holst, Lindroos, Kafatos, Pfeiffer, Martinez, Handjieva-Darlenska, Kunesova, Stender and van Baak report no conflict of interest.

\section{References}

1. Skov AR, Toubro S, Ronn B, Holm L, Astrup A. Randomized trial on protein vs carbohydrate in ad libitum fat reduced diet for the treatment of obesity. Int J Obes Relat Metab Disord. 1999;23(5):528-36.

2. Due A, Toubro S, Skov AR, Astrup A. Effect of normal-fat diets, either medium or high in protein, on body weight in overweight subjects: a randomised 1-year trial. Int J Obes Relat Metab Disord. 2004;28(10):1283-90.

3. Lejeune MP, Kovacs EM, Westerterp-Plantenga MS. Additional protein intake limits weight regain after weight loss in humans. The British journal of nutrition. 2005;93(2):281-9.

4. Westerterp-Plantenga MS, Lejeune MP, Nijs I, van Ooijen M, Kovacs EM. High protein intake sustains weight maintenance after body weight loss in humans. Int J Obes Relat Metab Disord. 2004;28(1):57-64.

5. Claessens M, van Baak MA, Monsheimer S, Saris WH. The effect of a low-fat, high-protein or highcarbohydrate ad libitum diet on weight loss maintenance and metabolic risk factors. Int J Obes (Lond). 2009;33(3):296-304. 
6. Paddon-Jones D, Westman E, Mattes RD, Wolfe RR, Astrup A, Westerterp-Plantenga M. Protein, weight management, and satiety. The American journal of clinical nutrition. 2008;87(5):1558S-61S.

7. Santesso N, AkI EA, Bianchi M, Mente A, Mustafa R, Heels-Ansdell D, et al. Effects of higher- versus lowerprotein diets on health outcomes: a systematic review and meta-analysis. Eur J Clin Nutr. 2012;66(7):780-8.

8. Wycherley TP, Moran LJ, Clifton PM, Noakes M, Brinkworth GD. Effects of energy-restricted high-protein, low-fat compared with standard-protein, low-fat diets: a meta-analysis of randomized controlled trials. Am J Clin Nutr. 2012;96(6):1281-98.

9. Delbridge EA, Prendergast LA, Pritchard JE, Proietto J. One-year weight maintenance after significant weight loss in healthy overweight and obese subjects: does diet composition matter? The American journal of clinical nutrition. 2009;90(5):1203-14.

10. Sacks FM, Bray GA, Carey VJ, Smith SR, Ryan DH, Anton SD, et al. Comparison of weight-loss diets with different compositions of fat, protein, and carbohydrates. N Engl J Med. 2009;360(9):859-73.

11. van Baak MA, Astrup A. Consumption of sugars and body weight. Obes Rev. 2009;10 Suppl 1:9-23.

12. Livesey G, Taylor R, Hulshof T, Howlett J. Glycemic response and health--a systematic review and metaanalysis: relations between dietary glycemic properties and health outcomes. The American journal of clinical nutrition. 2008;87(1):258S-68S.

13. Schwingshackl L, Hoffmann G. Long-term effects of low glycemic index/load vs. high glycemic index/load diets on parameters of obesity and obesity-associated risks: a systematic review and meta-analysis. Nutr Metab Cardiovasc Dis. 2013;23(8):699-706.

14. Larsen TM, Dalskov SM, van Baak M, Jebb SA, Papadaki A, Pfeiffer AF, et al. Diets with high or low protein content and glycemic index for weight-loss maintenance. N Engl J Med. 2010;363(22):2102-13.

15. Larsen TM, Dalskov S, van Baak M, al. e. The Diet, Obesity and Genes (Diogenes) dietary study in eight European countries - a comprehensive design for long term intervention. Obesity Reviews. 2010;11:7691.

16. Saris WH, Astrup A, Prentice AM, Zunft HJ, Formiguera X, Verboeket-van de Venne WP, et al. Randomized controlled trial of changes in dietary carbohydrate/fat ratio and simple vs complex carbohydrates on body weight and blood lipids: the CARMEN study. The Carbohydrate Ratio Management in European National diets. Int J Obes Relat Metab Disord. 2000;24(10):1310-8.

17. Skov AR, Toubro S, Raben A, Astrup A. A method to achieve control of dietary macronutrient composition in ad libitum diets consumed by free-living subjects. Eur J Clin Nutr. 1997;51(10):667-72.

18. Moore CS, Lindroos AK, Kreutzer M, al. e. Strategy to manipulate ad libitum macronutrient intake, and glycaemic index, across eight European countries in the DIOGENES study. Obesity Reviews. 2010;11:6775.

19. Aston LM, Jackson D, Monsheimer S, Whybrow S, Handjieva-Darlenska T, Kreutzer M, et al. Developing a methodology for assigning glycaemic index values to foods consumed across Europe. Obes Rev. 2010;11(1):92-100.

20. Larsen TM, Dalskov S, van Baak M, al. e. The Diet, Obesity and Genes (Diogenes) dietary study in eight European countries - a comprehensive design for long term intervention. Obesity Reviews. 2009.

21. Matsuda M, DeFronzo RA. Insulin sensitivity indices obtained from oral glucose tolerance testing: comparison with the euglycemic insulin clamp. Diabetes Care. 1999;22(9):1462-70.

22. Matthews DR, Hosker JP, Rudenski AS, Naylor BA, Treacher DF, Turner RC. Homeostasis model assessment: insulin resistance and beta-cell function from fasting plasma glucose and insulin concentrations in man. Diabetologia. 1985;28(7):412-9.

23. Gogebakan O, Kohl A, Osterhoff MA, van Baak MA, Jebb SA, Papadaki A, et al. Effects of weight loss and long-term weight maintenance with diets varying in protein and glycemic index on cardiovascular risk factors: the diet, obesity, and genes (DiOGenes) study: a randomized, controlled trial. Circulation. 2011;124(25):2829-38.

24. Westerterp KR, Goris AH. Validity of the assessment of dietary intake: problems of misreporting. Current opinion in clinical nutrition and metabolic care. 2002;5(5):489-93. 
25. Misciagna G, Logroscino G, De Michele G, Cisternino AM, Guerra V, Freudenheim JL. Fructosamine, glycated hemoglobin, and dietary carbohydrates. Clinica chimica acta; international journal of clinical chemistry. 2004;340(1-2):139-47.

26. Misciagna G, De Michele G, Cisternino AM, Guerra V, Logroscino G, Freudenheim JL. Dietary carbohydrates and glycated proteins in the blood in non diabetic subjects. Journal of the American College of Nutrition. 2005;24(1):22-9.

27. Jenkins DJ, Wolever TM, Collier GR, Ocana A, Rao AV, Buckley G, et al. Metabolic effects of a lowglycemic-index diet. The American journal of clinical nutrition. 1987;46(6):968-75.

28. Claessens M, van Baak MA, Monsheimer S, Saris WH. The effect of a low-fat, high-protein or highcarbohydrate ad libitum diet on weight loss maintenance and metabolic risk factors. Int J Obes (Lond). 2009. 
Supplementary information Figure 1 Trial profile

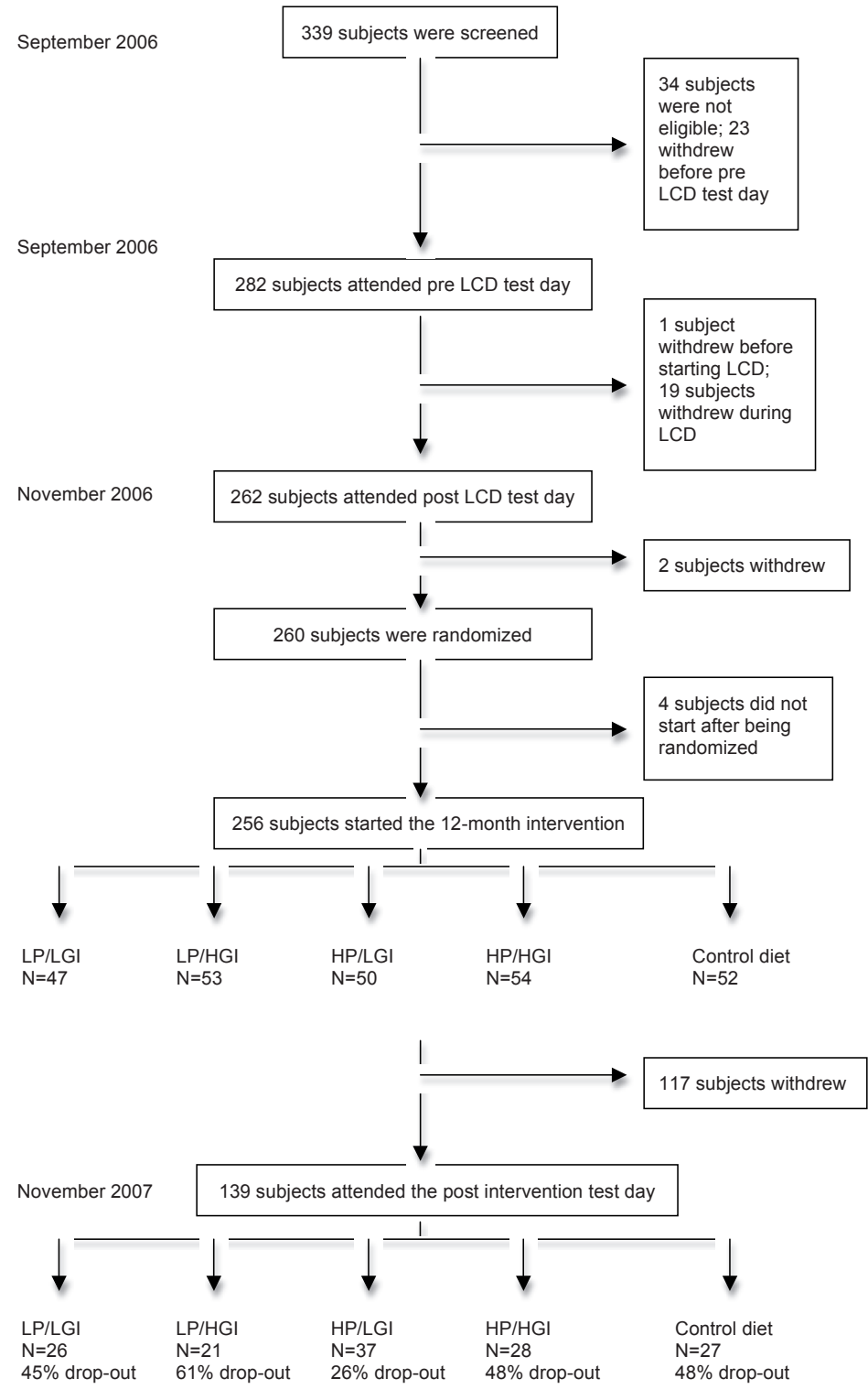


Supplementary information Figure 2 Body weight change during the 12-month randomized dietary intervention in the five diet groups (mean $\pm \mathrm{SE}$ ) for the completers $(\mathrm{N}=139)$.

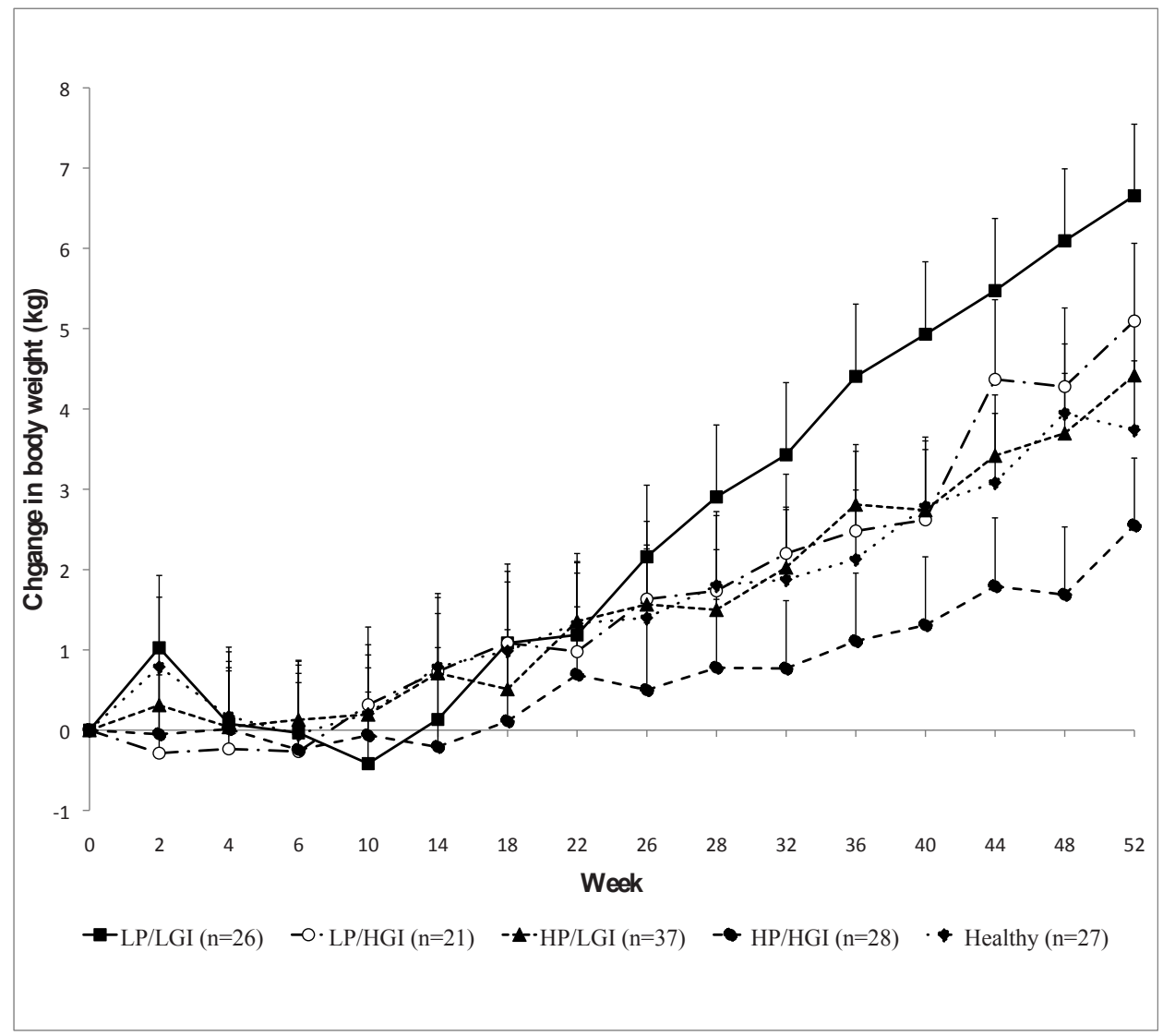

Linear mixed model analysis with repeated measurements adjusted for BMI at randomization, total weight loss during LCD period, age, diet group, center, family structure and gender. No significant differences among the 5 diet groups.

$\mathrm{LP} / \mathrm{LGI}=$ low protein/low glycemic index; $\mathrm{LP} / \mathrm{HGI}=$ low protein/high glycemic index; $\mathrm{HP} / \mathrm{LGI}=$ high protein/low glycemic index; $\mathrm{HP} / \mathrm{HGI}=$ high protein/high glycemic index 
Supplementary information Table 1a Subject characteristics (mean \pm SD) post-LCD (last day LCD) and urinary nitrogen and C-peptide excretion at baseline (pre LCD) (randomized subjects, $N=256$ ).

\begin{tabular}{|c|c|c|c|c|c|c|c|c|c|c|}
\hline \multirow[t]{3}{*}{ Variable } & \multicolumn{4}{|c|}{ Low Protein } & \multicolumn{5}{|c|}{ High Protein } & \multirow{3}{*}{$\begin{array}{l}\text { Control } \\
\text { Mean } \pm S D\end{array}$} \\
\hline & \multicolumn{2}{|c|}{$\begin{array}{l}\text { Low Glycemic } \\
\text { Index }\end{array}$} & \multicolumn{2}{|c|}{$\begin{array}{l}\text { High Glycemic } \\
\text { Index }\end{array}$} & \multicolumn{2}{|c|}{$\begin{array}{l}\text { Low Glycemic } \\
\text { Index }\end{array}$} & \multicolumn{2}{|c|}{$\begin{array}{l}\text { High Glycemic } \\
\text { Index }\end{array}$} & \multirow{3}{*}{$N$} & \\
\hline & $N$ & Mean $\pm S D$ & $N$ & Mean $\pm S D$ & $N$ & Mean $\pm S D$ & $N$ & Mean $\pm S D$ & & \\
\hline \multicolumn{10}{|c|}{ Anthropometric measures } & \\
\hline Gender (\%male) & 47 & 36 & 53 & 40 & 50 & 42 & 54 & 44 & 52 & 38 \\
\hline Age (years) & 47 & $42.5 \pm 5.1$ & 53 & $41.5 \pm 5.4$ & 50 & $41.0 \pm 6.1$ & 54 & $42.1 \pm 4.6$ & 52 & $43.2 \pm 5.8$ \\
\hline $\begin{array}{l}\% \text { Weight loss } \\
\text { during LCD (\%) }\end{array}$ & 47 & $11.7 \pm 2.4$ & 53 & $11.1 \pm 2.6$ & 50 & $11.0 \pm 2.2$ & 54 & $11.1 \pm 2.2$ & 52 & $11.2 \pm 3.1$ \\
\hline $\begin{array}{l}\text { Weight loss } \\
\text { during LCD (kg) }\end{array}$ & 47 & $11.8 \pm 3.3$ & 53 & $10.9 \pm 3.0$ & 50 & $11.1 \pm 2.8$ & 54 & $11.0 \pm 3.1$ & 52 & $11.3 \pm 4.3$ \\
\hline Weight (kg) & 47 & $89.3 \pm 15.2$ & 53 & $87.2 \pm 13.3$ & 50 & $90.3 \pm 15.3$ & 54 & $87.8 \pm 13.1$ & 52 & $89.3 \pm 13.2$ \\
\hline BMI $\left(\mathrm{kg} / \mathrm{m}^{2}\right)$ & 47 & $30.2 \pm 4.3$ & 53 & $29.7 \pm 3.7$ & 50 & $29.9 \pm 4.2$ & 54 & $29.5 \pm 3.9$ & 52 & $30.2 \pm 4.2$ \\
\hline $\begin{array}{l}\text { Fat-free mass } \\
(\mathrm{kg})\end{array}$ & 38 & $58.2 \pm 12.4$ & 45 & $56.6 \pm 10.8$ & 43 & $58.6 \pm 11.5$ & 44 & $57.8 \pm 11.6$ & 41 & $56.7 \pm 9.9$ \\
\hline Fat mass (kg) & 38 & $33.1 \pm 10.3$ & 45 & $30.4 \pm 10.8$ & 43 & $31.6 \pm 11.3$ & 44 & $30.6 \pm 9.8$ & 41 & $32.7 \pm 10.7$ \\
\hline $\begin{array}{l}\text { Waist circumfer- } \\
\text { ence }(\mathrm{cm})\end{array}$ & 47 & $96.6 \pm 10.8$ & 53 & $96.4 \pm 10.1$ & 50 & $97.3 \pm 12.2$ & 54 & $96.0 \pm 11.1$ & 52 & $98.9 \pm 12.4$ \\
\hline $\begin{array}{l}\text { Hip circumfer- } \\
\text { ence }(\mathrm{cm})\end{array}$ & 47 & $107.9 \pm 9.6$ & 52 & $105.3 \pm 9.3$ & 48 & $107.3 \pm 8.2$ & 52 & $105.3 \pm 8.4$ & 51 & $106.1 \pm 8.2$ \\
\hline $\begin{array}{l}\text { Sagittal diameter } \\
(\mathrm{cm})\end{array}$ & 46 & $20.9 \pm 2.9$ & 53 & $20.4 \pm 2.8$ & 49 & $20.7 \pm 3.1$ & 52 & $20.0 \pm 3.0$ & 52 & $20.7 \pm 2.9$ \\
\hline $\begin{array}{l}\text { Systolic blood } \\
\text { pressure }(\mathrm{mmHg})\end{array}$ & 47 & $118.9 \pm 12.6$ & 53 & $117.5 \pm 13.1$ & 50 & $118.3 \pm 12.2$ & 52 & $121.2 \pm 11.0$ & 52 & $117.4 \pm 13.3$ \\
\hline $\begin{array}{l}\text { Diastolic blood } \\
\text { pressure }(\mathrm{mmHg})\end{array}$ & 47 & $75.2 \pm 7.9$ & 53 & $72.8 \pm 8.1$ & 50 & $73.7 \pm 8.5$ & 52 & $75.4 \pm 8.2$ & 51 & $71.9 \pm 9.2$ \\
\hline $\begin{array}{l}\text { Total cholesterol } \\
\text { (mmol/L) }\end{array}$ & 45 & $3.60 \pm 0.73$ & 53 & $3.68 \pm 1.04$ & 49 & $3.73 \pm 0.87$ & 52 & $3.88 \pm 0.81$ & 52 & $3.81 \pm 0.88$ \\
\hline $\mathrm{HDL}(\mathrm{mmol} / \mathrm{L})$ & 45 & $0.97 \pm 0.18$ & 53 & $1.05 \pm 0.27$ & 49 & $1.06 \pm 0.28$ & 52 & $1.06 \pm 0.21$ & 52 & $1.04 \pm 0.24$ \\
\hline $\mathrm{LDL}$ (mmol/L) & 45 & $2.19 \pm 0.65$ & 52 & $2.14 \pm 0.93$ & 49 & $2.25 \pm 0.74$ & 52 & $2.37 \pm 0.74$ & 52 & $2.30 \pm 0.77$ \\
\hline $\begin{array}{l}\text { Triglycerides } \\
\text { (mmol/L) }\end{array}$ & 44 & $0.95 \pm 0.37$ & 51 & $0.93 \pm 0.36$ & 49 & $0.96 \pm 0.35$ & 52 & $0.99 \pm 0.39$ & 52 & $1.04 \pm 0.39$ \\
\hline $\begin{array}{l}\text { Adiponectin } \\
(\mu \mathrm{g} / \mathrm{mL})\end{array}$ & 47 & $8.07 \pm 3.10$ & 53 & $7.49 \pm 3.27$ & 49 & $7.24 \pm 2.80$ & 51 & $7.82 \pm 3.76$ & 52 & $8.29 \pm 3.51$ \\
\hline CRP (mg/L) & 43 & $2.39 \pm 2.42$ & 51 & $2.75 \pm 2.58$ & 47 & $2.62 \pm 2.24$ & 52 & $2.46 \pm 2.53$ & 47 & $2.60 \pm 2.52$ \\
\hline $\begin{array}{l}\text { Fasting glucose } \\
\text { (mmol/L) }\end{array}$ & 47 & $4.63 \pm 0.41$ & 53 & $4.53 \pm 0.43$ & 45 & $4.65 \pm 0.85$ & 52 & $4.78 \pm 0.52$ & 51 & $4.57 \pm 0.44$ \\
\hline $\begin{array}{l}\text { Fasting insulin } \\
\text { (mmol/L) }\end{array}$ & 46 & $7.71 \pm 3.43$ & 51 & $8.39 \pm 5.24$ & 47 & $6.90 \pm 3.40$ & 50 & $7.84 \pm 4.17$ & 50 & $\begin{array}{l}10.19 \pm 11.9 \\
8\end{array}$ \\
\hline $\begin{array}{l}\text { Fructosamine } \\
(\mu \mathrm{mol} / \mathrm{L})\end{array}$ & 45 & $196.7 \pm 22.1$ & 53 & $202.3 \pm 32.4$ & 49 & $199.3 \pm 25.6$ & 52 & $205.1 \pm 25.0$ & 52 & $199.2 \pm 26.6$ \\
\hline
\end{tabular}




\begin{tabular}{|c|c|c|c|c|c|c|c|c|c|c|}
\hline \multirow[t]{3}{*}{ Variable } & \multicolumn{4}{|c|}{ Low Protein } & \multicolumn{5}{|c|}{ High Protein } & \multirow{3}{*}{$\begin{array}{l}\text { Control } \\
\text { Mean } \pm S D\end{array}$} \\
\hline & \multicolumn{2}{|c|}{$\begin{array}{l}\text { Low Glycemic } \\
\text { Index }\end{array}$} & \multicolumn{2}{|c|}{$\begin{array}{l}\text { High Glycemic } \\
\text { Index }\end{array}$} & \multicolumn{2}{|c|}{$\begin{array}{l}\text { Low Glycemic } \\
\text { Index }\end{array}$} & \multicolumn{3}{|c|}{$\begin{array}{l}\text { High Glycemic } \\
\text { Index }\end{array}$} & \\
\hline & $N$ & Mean $\pm S D$ & $N$ & Mean $\pm S D$ & $N$ & Mean $\pm S D$ & $N$ & Mean $\pm S D$ & $N$ & \\
\hline \multicolumn{11}{|c|}{ Anthropometric measures } \\
\hline $\begin{array}{l}\text { 2h Glucose } \\
\text { (mmol/L) }\end{array}$ & 43 & $6.63 \pm 1.48$ & 52 & $7.09 \pm 2.04$ & 47 & $6.62 \pm 1.87$ & 52 & $6.60 \pm 1.80$ & 51 & $6.53 \pm 1.93$ \\
\hline HOMA-IR index & 46 & $1.86 \pm 0.87$ & 51 & $1.99 \pm 1.25$ & 46 & $1.73 \pm 1.15$ & 50 & $1.95 \pm 1.12$ & 49 & $2.40 \pm 2.89$ \\
\hline HOMA-\%B index & 46 & $181.9 \pm 118.2$ & 51 & $214.1 \pm 263.8$ & 46 & $209.1 \pm 246.0$ & 50 & $156.0 \pm 75.4$ & 49 & $\begin{array}{l}245.6 \pm 256 . \\
6\end{array}$ \\
\hline Matsuda index & 44 & $7.49 \pm 3.20$ & 50 & $7.36 \pm 3.53$ & 45 & $8.21 \pm 4.25$ & 50 & $7.79 \pm 4.41$ & 49 & $6.73 \pm 3.28$ \\
\hline $\begin{array}{l}\text { Urinary C- } \\
\text { Peptide } \\
\text { (nmol/24h) }\end{array}$ & 42 & $22.8 \pm 22.1$ & 47 & $22.0 \pm 17.0$ & 47 & $24.4 \pm 24.7$ & 53 & $19.9 \pm 17.4$ & 49 & $23.1 \pm 18.7$ \\
\hline $\begin{array}{l}\text { Urinary Nitrogen } \\
\text { (g/24h) }\end{array}$ & 43 & $10.4 \pm 2.9$ & 48 & $110 . \pm 4.2$ & 47 & $13.1 \pm 5.1$ & 53 & $14.1 \pm 5.0$ & 49 & $12.2 \pm 4.6$ \\
\hline
\end{tabular}

No statistically significant differences between the 5 diet groups (one way ANOVA). 
Supplementary information Table $\mathbf{1 b}$. Subject characteristics (mean \pm SD) post-LCD (last day LCD) and urinary nitrogen and C-peptide excretion at baseline (pre LCD) (completers only, $N=139$ ).

\begin{tabular}{|c|c|c|c|c|c|c|c|c|c|c|}
\hline \multirow[t]{3}{*}{ Variable } & \multicolumn{4}{|c|}{ Low Protein } & \multicolumn{4}{|c|}{ High Protein } & \multicolumn{2}{|c|}{ Control } \\
\hline & \multicolumn{2}{|c|}{$\begin{array}{l}\text { Low Glycemic } \\
\text { Index }\end{array}$} & \multicolumn{2}{|c|}{$\begin{array}{l}\text { High Glycemic } \\
\text { Index }\end{array}$} & \multicolumn{2}{|c|}{$\begin{array}{l}\text { Low Glycemic } \\
\text { Index }\end{array}$} & \multicolumn{2}{|c|}{$\begin{array}{l}\text { High Glycemic } \\
\text { Index }\end{array}$} & \multirow{3}{*}{$N$} & \multirow{3}{*}{ Mean $\pm S D$} \\
\hline & $N$ & Mean $\pm S D$ & $N$ & Mean $\pm S D$ & $N$ & Mean $\pm S D$ & $N$ & Mean $\pm S D$ & & \\
\hline \multicolumn{9}{|c|}{ Anthropometric measures } & & \\
\hline Gender (\%male) & 26 & 31 & 21 & 38 & 37 & 40 & 28 & 39 & 27 & 44 \\
\hline ge (years) & 26 & $42.8 \pm 5.2$ & 21 & $42.2 \pm 4.6$ & 37 & $41.6 \pm 6.0$ & 28 & $42.4 \pm 4.3$ & 27 & $44.5 \pm 6.8$ \\
\hline $\begin{array}{l}\text { \%Weight loss } \\
\text { during LCD (\%) }\end{array}$ & 26 & $12.1 \pm 2.5$ & 21 & $10.9 \pm 2.3$ & 37 & $10.9 \pm 2.0$ & 28 & $11.2 \pm 2.4$ & 27 & $11.8 \pm 2.9$ \\
\hline $\begin{array}{l}\text { Weight loss } \\
\text { during LCD (kg) }\end{array}$ & 26 & $12.7 \pm 3.5$ & 21 & $10.1 \pm 3.1$ & 37 & $11.2 \pm 2.9$ & 28 & $11.1 \pm 3.5$ & 27 & $11.9 \pm 4.5$ \\
\hline Weight (kg) & 26 & $91.5 \pm 16.5$ & 21 & $82.2 \pm 12.1$ & 37 & $91.5 \pm 16.1$ & 28 & $86.5 \pm 11.7$ & 27 & $87.3 \pm 13.3$ \\
\hline $\mathrm{BMI}\left(\mathrm{kg} / \mathrm{m}^{2}\right)$ & 26 & $30.6 \pm 4.4$ & 21 & $28.5 \pm 2.7$ & 37 & $30.4 \pm 4.3$ & 28 & $28.7 \pm 3.7$ & 27 & $29.2 \pm 3.6$ \\
\hline Fat-free mass $(\mathrm{kg})$ & ) 21 & $60.2 \pm 12.5$ & 17 & $52.1 \pm 10.2$ & 31 & $57.1 \pm 10.7$ & 21 & $57.1 \pm 12.5$ & 22 & $57.2 \pm 10.9$ \\
\hline Fat mass $(\mathrm{kg})^{*}$ & 21 & $35.5 \pm 10.7$ & 17 & $27.1 \pm 9.2$ & 31 & $34.3 \pm 11.5$ & 21 & $28.6 \pm 9.1$ & 22 & $30.1 \pm 10.2$ \\
\hline $\begin{array}{l}\text { Waist circumfe- } \\
\text { rence }(\mathrm{cm})\end{array}$ & 26 & $97.6 \pm 11.5$ & 21 & $92.7 \pm 8.9$ & 37 & $98.6 \pm 13.4$ & 28 & $93.6 \pm 11.7$ & 27 & $96.2 \pm 11.9$ \\
\hline $\begin{array}{l}\text { Hip circumference } \\
(\mathrm{cm})^{*}\end{array}$ & e26 & $110.3 \pm 10.5$ & 21 & $102.6 \pm 7.9$ & 36 & $108.7 \pm 8.4$ & 28 & $106.5 \pm 8.7$ & 27 & $104.2 \pm 9.0$ \\
\hline $\begin{array}{l}\text { Sagittal diameter } \\
(\mathrm{cm})^{*}\end{array}$ & 26 & $21.2 \pm 3.3$ & 21 & $19.6 \pm 2.3$ & 36 & $21.3 \pm 3.1$ & 28 & $19.4 \pm 2.7$ & 27 & $19.7 \pm 2.4$ \\
\hline $\begin{array}{l}\text { Systolic blood } \\
\text { pressure }(\mathrm{mmHg})\end{array}$ & 26 & $117.3 \pm 11.9$ & 21 & $115.9 \pm 15.6$ & 37 & $118.3 \pm 12.8$ & 28 & $120.6 \pm 12.0$ & 27 & $116.7 \pm 12.3$ \\
\hline $\begin{array}{l}\text { Diastolic blood } \\
\text { pressure }(\mathrm{mmHg})\end{array}$ & 26 & $75.7 \pm 8.3$ & 21 & $72.9 \pm 9.8$ & 37 & $74.4 \pm 8.8$ & 28 & $74.2 \pm 7.5$ & 27 & $71.4 \pm 8.7$ \\
\hline $\begin{array}{l}\text { Total cholesterol } \\
(\mathrm{mmol} / \mathrm{L})\end{array}$ & 26 & $3.65 \pm 0.83$ & 21 & $3.85 \pm 1.04$ & 36 & $3.70 \pm 0.80$ & 27 & $3.56 \pm 0.84$ & 27 & $3.69 \pm 0.84$ \\
\hline $\mathrm{HDL}(\mathrm{mmol} / \mathrm{L})^{*}$ & 26 & $0.93 \pm 0.14$ & 21 & $1.12 \pm 0.26$ & 36 & $1.03 \pm 0.26$ & 27 & $1.09 \pm 0.19$ & 27 & $1.05 \pm 0.25$ \\
\hline LDL (mmol/L) & 26 & $2.27 \pm 0.72$ & 20 & $2.10 \pm 1.07$ & 36 & $2.22 \pm 0.67$ & 27 & $2.23 \pm 0.69$ & 27 & $2.10 \pm 0.74$ \\
\hline $\begin{array}{l}\text { Triglycerides } \\
\text { (mmol/L) }\end{array}$ & 26 & $1.01 \pm 0.41$ & 19 & $0.97 \pm 0.35$ & 36 & $0.99 \pm 0.37$ & 27 & $0.89 \pm 0.29$ & 27 & $0.92 \pm 0.31$ \\
\hline $\begin{array}{l}\text { Adiponectin } \\
(\mu \mathrm{g} / \mathrm{mL})^{*}\end{array}$ & 26 & $8.38 \pm 3.42$ & 21 & $7.02 \pm 3.47$ & 37 & $7.15 \pm 2.95$ & 26 & $7.68 \pm 3.67$ & 27 & $9.94 \pm 3.75$ \\
\hline CRP (mg/L) & 26 & $2.34 \pm 2.45$ & 21 & $3.36 \pm 3.38$ & 35 & $2.35 \pm 2.01$ & 27 & $2.53 \pm 2.59$ & 24 & $1.84 \pm 1.31$ \\
\hline $\begin{array}{l}\text { Fasting glucose } \\
(\mathrm{mmol} / \mathrm{L})\end{array}$ & 26 & $4.60 \pm 0.46$ & 21 & $4.48 \pm 0.35$ & 34 & $4.67 \pm 0.34$ & 27 & $4.60 \pm 0.43$ & 27 & $4.66 \pm 0.44$ \\
\hline $\begin{array}{l}\text { Fasting insulin } \\
(\mathrm{mmol} / \mathrm{L})\end{array}$ & 25 & $7.55 \pm 3.70$ & 20 & $7.78 \pm 3.52$ & 35 & $6.94 \pm 3.50$ & 26 & $6.39 \pm 3.67$ & 27 & $\begin{array}{l}10.99 \pm 16.0 \\
7\end{array}$ \\
\hline $\begin{array}{l}\text { Fructosamine } \\
(\mu \mathrm{mol} / \mathrm{L})\end{array}$ & 26 & $196.6 \pm 22.1$ & 21 & $206.7 \pm 34.9$ & 36 & $192.6 \pm 22.3$ & 27 & $207.1 \pm 24.4$ & 27 & $203.7 \pm 27.2$ \\
\hline 2h Glucose & 24 & $6.40 \pm 1.31$ & 21 & $7.01 \pm 2.36$ & 34 & $6.75 \pm 1.96$ & 27 & $6.76 \pm 1.82$ & 27 & $6.11 \pm 1.57$ \\
\hline
\end{tabular}


THE DIOGENES TRIAL 12 -MONTH RESULTS

\begin{tabular}{|c|c|c|c|c|c|c|c|c|c|c|}
\hline \multirow[t]{3}{*}{ Variable } & \multicolumn{4}{|c|}{ Low Protein } & \multicolumn{4}{|c|}{ High Protein } & \multicolumn{2}{|c|}{ Control } \\
\hline & \multicolumn{2}{|c|}{$\begin{array}{l}\text { Low Glycemic } \\
\text { Index }\end{array}$} & \multicolumn{2}{|c|}{$\begin{array}{l}\text { High Glycemic } \\
\text { Index }\end{array}$} & \multicolumn{2}{|c|}{$\begin{array}{l}\text { Low Glycemic } \\
\text { Index }\end{array}$} & \multicolumn{2}{|c|}{$\begin{array}{l}\text { High Glycemic } \\
\text { Index }\end{array}$} & \multirow{3}{*}{$N$} & \multirow{3}{*}{ Mean $\pm S D$} \\
\hline & $N$ & Mean $\pm S D$ & $N$ & Mean $\pm S D$ & $N$ & Mean $\pm S D$ & $N$ & Mean $\pm S D$ & & \\
\hline \multicolumn{9}{|c|}{ Anthropometric measures } & & \\
\hline \multicolumn{11}{|l|}{$\overline{(\mathrm{mmol} / \mathrm{L})}$} \\
\hline HOMA-IR index & 25 & $1.83 \pm 0.99$ & 20 & $1.83 \pm 0.82$ & 34 & $1.70 \pm 0.89$ & 26 & $1.54 \pm 0.96$ & 27 & $2.61 \pm 3.83$ \\
\hline HOMA-\%B index & 25 & $187.0 \pm 128.6$ & 20 & $194.7 \pm 100.1$ & 134 & $167.0 \pm 151.6$ & 626 & $149.1 \pm 77.8$ & 27 & $\begin{array}{l}254.9 \pm 310 \\
8\end{array}$ \\
\hline Matsuda index & 24 & $7.89 \pm 3.62$ & 20 & $7.20 \pm 3.54$ & 34 & $7.94 \pm 3.72$ & 26 & $9.29 \pm 5.03$ & 27 & $7.40 \pm 3.76$ \\
\hline $\begin{array}{l}\text { Urinary C-Peptide } \\
(\mathrm{nmol} / 24 \mathrm{~h})\end{array}$ & 25 & $34.8 \pm 28.3$ & 20 & $24.9 \pm 16.4$ & 36 & $30.5 \pm 21.1$ & 27 & $23.5 \pm 16.3$ & 26 & $24.4 \pm 14.8$ \\
\hline $\begin{array}{l}\text { Urinary Nitrogen } \\
\text { (g/24h) }\end{array}$ & 25 & $12.6 \pm 3.6$ & 20 & $12.8 \pm 4.6$ & 37 & $13.6 \pm 4.8$ & 27 & $12.3 \pm 3.3$ & 26 & $12.8 \pm 4.0$ \\
\hline
\end{tabular}

* statistically significant difference between the 5 diet groups (one way ANOVA, $P<0.05$ ). 
Supplementary information Table 2 Self-reported total energy and macronutrient intake, glycemic index, glycemic load and fiber in the 5 diet groups at different time points of the 12-month randomized period (mean and 95\% confidence interval).

\begin{tabular}{|c|c|c|c|c|c|c|}
\hline \multirow[t]{3}{*}{ Variable } & \multicolumn{2}{|c|}{ Low Protein } & \multicolumn{2}{|c|}{ High Protein } & \multirow[t]{2}{*}{ Control } & \multirow[t]{3}{*}{$P$-value* } \\
\hline & $\begin{array}{l}\text { Low glycemic } \\
\text { index }\end{array}$ & $\begin{array}{l}\text { High glycemic } \\
\text { index }\end{array}$ & $\begin{array}{l}\text { Low glycemic } \\
\text { index }\end{array}$ & $\begin{array}{l}\text { High glycemic } \\
\text { index }\end{array}$ & & \\
\hline & $\begin{array}{ll}N \quad \text { Mean } \\
\\
\quad(95 \% \mathrm{Cl})\end{array}$ & $\begin{array}{ll}N \quad \text { Mean } \\
\\
\quad(95 \% \mathrm{Cl})\end{array}$ & $\begin{array}{ll}N \quad \text { Mean } \\
\\
\quad(95 \% \mathrm{Cl})\end{array}$ & $\begin{array}{ll}N \quad \text { Mean } \\
\\
\quad(95 \% \mathrm{Cl})\end{array}$ & $\begin{array}{ll}N \quad \text { Mean } \\
\\
(95 \% \mathrm{Cl})\end{array}$ & \\
\hline
\end{tabular}

\begin{tabular}{|c|c|c|c|c|c|c|c|c|c|c|c|}
\hline \multicolumn{12}{|c|}{ Energy (kJ/day) } \\
\hline At baseline & 46 & $\begin{array}{l}9330 \\
(8569 \text { to } \\
10090)\end{array}$ & 52 & $\begin{array}{l}10069 \\
(9115 \text { to } \\
11023)\end{array}$ & 50 & $\begin{array}{l}9536 \\
(8756 \text { to } \\
10315)\end{array}$ & 49 & $\begin{array}{l}9197 \\
(8234 \text { to } \\
10160)\end{array}$ & 47 & $\begin{array}{l}9759 \\
\text { (9055 to } \\
10462)\end{array}$ & 0.595 \\
\hline At week 4 & 38 & $\begin{array}{l}5974 \\
(5395 \text { to } \\
6552)\end{array}$ & 49 & $\begin{array}{l}6378 \\
(5825 \text { to } \\
6931)\end{array}$ & 48 & $\begin{array}{l}6723 \\
(6178 \text { to } \\
7267)\end{array}$ & 52 & $\begin{array}{l}6374 \\
\text { (5827 to } \\
6922)\end{array}$ & 46 & $\begin{array}{l}6923 \\
(6398 \text { to } \\
7448)\end{array}$ & 0.169 \\
\hline At week 26 & 27 & $\begin{array}{l}7834 \\
(7200 \text { to } \\
8468)\end{array}$ & 30 & $\begin{array}{l}7496 \\
(6422 \text { to } \\
8570)\end{array}$ & 40 & $\begin{array}{l}7233 \\
(6482 \text { to } \\
7984)\end{array}$ & 35 & $\begin{array}{l}6458 \\
(5801 \text { to } \\
7115)\end{array}$ & 33 & $\begin{array}{l}7607 \\
(6920 \text { to } \\
8294)\end{array}$ & 0.108 \\
\hline At week 52 & 21 & $\begin{array}{l}6906 \\
(6071 \text { to } \\
7741)\end{array}$ & 15 & $\begin{array}{l}6728 \\
(5372 \text { to } \\
8085)\end{array}$ & 27 & $\begin{array}{l}7336 \\
(6525 \text { to } \\
8146)\end{array}$ & 22 & $\begin{array}{l}7029 \\
(5860 \text { to } \\
8198)\end{array}$ & 24 & $\begin{array}{l}8498 \\
(7383 \text { to } \\
9613)\end{array}$ & 0.099 \\
\hline \multicolumn{12}{|c|}{ Carbohydrate (\% of total energy intake) } \\
\hline At baseline & 46 & $\begin{array}{l}46.4 \\
(44.5 \text { to } \\
48.4)\end{array}$ & 52 & $\begin{array}{l}44.9 \\
(42.6 \text { to } \\
47.3)\end{array}$ & 50 & $\begin{array}{l}45.0 \\
(42.9 \text { to } \\
47.1)\end{array}$ & 49 & $\begin{array}{l}46.4 \\
(44.6 \text { to } \\
48.3)\end{array}$ & 47 & $\begin{array}{l}45.7 \\
(43.4 \text { to } \\
48.1)\end{array}$ & 0.754 \\
\hline At week 4 & 38 & $\begin{array}{l}56.3 \\
(54.1 \text { to } \\
58.5)\end{array}$ & 49 & $\begin{array}{l}55.2 \\
(52.8 \text { to } \\
57.6)\end{array}$ & 48 & $\begin{array}{l}45.2 \\
(43.3 \text { to } \\
47.1)\end{array}$ & 52 & $\begin{array}{l}48.2 \\
(46.4 \text { to } \\
49.9)\end{array}$ & 46 & $\begin{array}{l}50.8 \\
(48.2 \text { to } \\
53.4)\end{array}$ & $<0.001$ \\
\hline At week 26 & 27 & $\begin{array}{l}57.1 \\
(54.7 \text { to } \\
59.3)\end{array}$ & 30 & $\begin{array}{l}53.3 \\
(50.2 \text { to } \\
56.4)\end{array}$ & 40 & $\begin{array}{l}47.4 \\
(45.4 \text { to } \\
49.5)\end{array}$ & 35 & $\begin{array}{l}46.5 \\
(44.8 \text { to } \\
48.3)\end{array}$ & 33 & $\begin{array}{l}50.4 \\
(48.0 \text { to } \\
52.8)\end{array}$ & $<0.001$ \\
\hline At week 52 & 21 & $\begin{array}{l}56.3 \\
(52.6 \text { to } \\
60.0)\end{array}$ & 15 & $\begin{array}{l}54.1 \\
(48.8 \text { to } \\
59.4)\end{array}$ & 27 & $\begin{array}{l}46.5 \\
(44.3 \text { to } \\
48.8)\end{array}$ & 22 & $\begin{array}{l}47.6 \\
(44.4 \text { to } \\
50.8)\end{array}$ & 24 & $\begin{array}{l}45.9 \\
(42.0 \text { to } \\
49.9)\end{array}$ & $<0.001$ \\
\hline \multicolumn{12}{|c|}{ Fat (\% of total energy intake) } \\
\hline At baseline & 46 & $\begin{array}{l}34.8 \\
(33.2 \text { to } \\
36.5)\end{array}$ & 52 & $\begin{array}{l}35.9 \\
(34.0 \text { to } \\
37.7)\end{array}$ & 50 & $\begin{array}{l}35.7 \\
(33.9 \text { to } \\
37.6)\end{array}$ & 49 & $\begin{array}{l}34.6 \\
(32.8 \text { to } \\
36.4)\end{array}$ & 47 & $\begin{array}{l}35.4 \\
(33.4 \text { to } \\
37.3)\end{array}$ & 0.820 \\
\hline At week 4 & 38 & $\begin{array}{l}26.6 \\
(24.2 \text { to } \\
29.0)\end{array}$ & 49 & $\begin{array}{l}25.4 \\
(23.8 \text { to } \\
26.9)\end{array}$ & 48 & $\begin{array}{l}30.1 \\
(28.0 \text { to } \\
32.3)\end{array}$ & 52 & $\begin{array}{l}27.6 \\
(26.1 \text { to } \\
29.1)\end{array}$ & 46 & $\begin{array}{l}27.8 \\
(25.5 \text { to } \\
30.0)\end{array}$ & 0.010 \\
\hline At week 26 & 27 & $\begin{array}{l}26.1 \\
(23.9 \text { to } \\
28.3)\end{array}$ & 30 & $\begin{array}{l}27.0 \\
(24.5 \text { to } \\
29.6)\end{array}$ & 40 & $\begin{array}{l}27.9 \\
(26.0 \text { to } \\
29.8)\end{array}$ & 35 & $\begin{array}{l}28.3 \\
(26.5 \text { to } \\
30.2)\end{array}$ & 33 & $\begin{array}{l}28.2 \\
(26.4 \text { to } \\
30.1)\end{array}$ & 0.547 \\
\hline At week 52 & 21 & 27.4 & 15 & 26.3 & 27 & 29.4 & 22 & 28.5 & 24 & 30.7 & 0.333 \\
\hline
\end{tabular}




\begin{tabular}{|c|c|c|c|c|c|c|c|c|c|c|c|}
\hline \multirow[t]{3}{*}{ Variable } & \multicolumn{4}{|c|}{ Low Protein } & \multicolumn{4}{|c|}{ High Protein } & \multirow{2}{*}{\multicolumn{2}{|c|}{ Control }} & \multirow[t]{3}{*}{$P$-value* } \\
\hline & \multicolumn{2}{|c|}{$\begin{array}{l}\text { Low glycemic } \\
\text { index }\end{array}$} & \multicolumn{2}{|c|}{$\begin{array}{l}\text { High glycemic } \\
\text { index }\end{array}$} & \multicolumn{2}{|c|}{$\begin{array}{l}\text { Low glycemic } \\
\text { index }\end{array}$} & \multicolumn{2}{|c|}{$\begin{array}{l}\text { High glycemic } \\
\text { index }\end{array}$} & & & \\
\hline & $N$ & $\begin{array}{l}\text { Mean } \\
(95 \% \mathrm{Cl})\end{array}$ & $N$ & $\begin{array}{l}\text { Mean } \\
(95 \% \mathrm{Cl})\end{array}$ & $N$ & $\begin{array}{l}\text { Mean } \\
(95 \% \mathrm{Cl})\end{array}$ & $N$ & $\begin{array}{l}\text { Mean } \\
(95 \% \mathrm{Cl})\end{array}$ & $N$ & $\begin{array}{l}\text { Mean } \\
(95 \% \mathrm{Cl})\end{array}$ & \\
\hline \multicolumn{12}{|c|}{ Energy and macronutrient intake } \\
\hline & & $\begin{array}{l}(24.4 \text { to } \\
30.3)\end{array}$ & & $\begin{array}{l}\text { (21.4 to } \\
31.2)\end{array}$ & & $\begin{array}{l}(27.2 \text { to } \\
31.6)\end{array}$ & & $\begin{array}{l}(25.3 \text { to } \\
31.6)\end{array}$ & & $\begin{array}{l}(27.3 \text { to } \\
34.1)\end{array}$ & \\
\hline \multicolumn{12}{|c|}{ Protein (\% of total energy intake) } \\
\hline At baseline & 46 & $\begin{array}{l}17.4 \\
(16.2 \text { to } \\
18.5)\end{array}$ & 52 & $\begin{array}{l}16.6 \\
(15.5 \text { to } \\
17.8)\end{array}$ & 50 & $\begin{array}{l}16.5 \\
(15.6 \text { to } \\
17.4)\end{array}$ & 49 & $\begin{array}{l}16.3 \\
(15.4 \text { to } \\
17.2)\end{array}$ & 47 & $\begin{array}{l}15.7 \\
(14.8 \text { to } \\
16.6)\end{array}$ & 0.251 \\
\hline At week 4 & 38 & $\begin{array}{l}16.1 \\
(15.0 \text { to } \\
17.1)\end{array}$ & 49 & $\begin{array}{l}16.9 \\
(16.0 \text { to } \\
17.8)\end{array}$ & 48 & $\begin{array}{l}22.8 \\
(21.5 \text { to } \\
24.1)\end{array}$ & 52 & $\begin{array}{l}22.8 \\
(21.6 \text { to } \\
24.0)\end{array}$ & 46 & $\begin{array}{l}19.6 \\
(18.5 \text { to } \\
20.7)\end{array}$ & $<0.001$ \\
\hline At week 26 & 27 & $\begin{array}{l}15.9 \\
(14.7 \text { to } \\
17.2)\end{array}$ & 30 & $\begin{array}{l}17.0 \\
(15.5 \text { to } \\
18.5)\end{array}$ & 40 & $\begin{array}{l}23.0 \\
(21.6 \text { to } \\
24.4)\end{array}$ & 35 & $\begin{array}{l}24.6 \\
(22.9 \text { to } \\
26.2)\end{array}$ & 33 & $\begin{array}{l}19.0 \\
(17.8 \text { to } \\
20.1)\end{array}$ & $<0.001$ \\
\hline At week 52 & 21 & $\begin{array}{l}15.1 \\
(13.7 \text { to } \\
16.5)\end{array}$ & 15 & $\begin{array}{l}16.6 \\
(14.5 \text { to } \\
18.7)\end{array}$ & 27 & $\begin{array}{l}22.0 \\
(20.6 \text { to } \\
23.4)\end{array}$ & 22 & $\begin{array}{l}23.6 \\
(20.3 \text { to } \\
26.9)\end{array}$ & 24 & $\begin{array}{l}18.6 \\
(16.4 \text { to } \\
20.8)\end{array}$ & $<0.001$ \\
\hline \multicolumn{12}{|c|}{ Glycemic index } \\
\hline At baseline & 46 & $\begin{array}{l}62.9 \\
(61.3 \text { to } \\
64.4)\end{array}$ & 52 & $\begin{array}{l}62.3 \\
(61.0 \text { to } \\
63.6)\end{array}$ & 50 & $\begin{array}{l}63.5 \\
(62.2 \text { to } \\
64.8)\end{array}$ & 49 & $\begin{array}{l}62.3 \\
(60.9 \text { to } \\
63.7)\end{array}$ & 47 & $\begin{array}{l}63.2 \\
(62.0 \text { to } \\
64.3)\end{array}$ & 0.627 \\
\hline At week 4 & 38 & $\begin{array}{l}55.8 \\
(54.2 \text { to } \\
57.4)\end{array}$ & 49 & $\begin{array}{l}63.1 \\
(61.5 \text { to } \\
64.6)\end{array}$ & 48 & $\begin{array}{l}57.9 \\
(56.3 \text { to } \\
59.6)\end{array}$ & 52 & $\begin{array}{l}64.3 \\
(62.6 \text { to } \\
66.0)\end{array}$ & 46 & $\begin{array}{l}60.8 \\
(59.4 \text { to } \\
62.3)\end{array}$ & $<0.001$ \\
\hline At week 26 & 27 & $\begin{array}{l}56.4 \\
(54.6 \text { to } \\
58.3)\end{array}$ & 30 & $\begin{array}{l}63.6 \\
(61.9 \text { to } \\
65.2)\end{array}$ & 40 & $\begin{array}{l}56.0 \\
(54.3 \text { to } \\
57.7)\end{array}$ & 35 & $\begin{array}{l}62.9 \\
(61.2 \text { to } \\
64.6)\end{array}$ & 33 & $\begin{array}{l}60.1 \\
(58.5 \text { to } \\
61.6)\end{array}$ & $<0.001$ \\
\hline At week 52 & 21 & $\begin{array}{l}58.1 \\
(55.5 \text { to } \\
60.7)\end{array}$ & 15 & $\begin{array}{l}63.2 \\
(60.6 \text { to } \\
65.8)\end{array}$ & 27 & $\begin{array}{l}57.5 \\
(55.6 \text { to } \\
59.5)\end{array}$ & 22 & $\begin{array}{l}62.5 \\
(59.1 \text { to } \\
65.8)\end{array}$ & 24 & $\begin{array}{l}60.7 \\
(58.9 \text { to } \\
62.6)\end{array}$ & 0.003 \\
\hline \multicolumn{12}{|c|}{ Glycemic load (g/day) } \\
\hline At baseline & 46 & $\begin{array}{l}159.8 \\
(146.2 \text { to } \\
173.4)\end{array}$ & 52 & $\begin{array}{l}167.3 \\
(147.8 \text { to } \\
186.7)\end{array}$ & 50 & $\begin{array}{l}159.2 \\
(145.0 \text { to } \\
173.4)\end{array}$ & 49 & $\begin{array}{l}157.3 \\
(137.7 \text { to } \\
177.0)\end{array}$ & 47 & $\begin{array}{l}164.5 \\
(150.7 \text { to } \\
178.2)\end{array}$ & 0.905 \\
\hline At week 4 & 38 & $\begin{array}{l}110.9 \\
\text { (98.0 to } \\
123.8 \text { ) }\end{array}$ & 49 & $\begin{array}{l}130.3 \\
(116.5 \text { to } \\
144.0)\end{array}$ & 48 & $\begin{array}{l}102.6 \\
\text { (93.0 to } \\
112.1)\end{array}$ & 52 & $\begin{array}{l}116.9 \\
(104.6 \text { to } \\
129.2)\end{array}$ & 46 & $\begin{array}{l}126.7 \\
(113.3 \text { to } \\
140.2)\end{array}$ & 0.010 \\
\hline At week 26 & 27 & $\begin{array}{l}148.4 \\
(134.4 \text { to } \\
162.3)\end{array}$ & 30 & $\begin{array}{l}148.0 \\
(124.8 \text { to } \\
171.2)\end{array}$ & 40 & $\begin{array}{l}111.6 \\
\text { (99.3 to } \\
123.9)\end{array}$ & 35 & $\begin{array}{l}112.8 \\
\text { (98.5 to } \\
127.0)\end{array}$ & 33 & $\begin{array}{l}134.2 \\
(122.0 \text { to } \\
146.4)\end{array}$ & $<0.001$ \\
\hline At week 52 & 21 & $\begin{array}{l}134.4 \\
\text { (112.6 to }\end{array}$ & 15 & $\begin{array}{l}136.7 \\
(102.0 \text { to }\end{array}$ & 27 & $\begin{array}{l}113.6 \\
\text { (102.3 to }\end{array}$ & 22 & $\begin{array}{l}126.1 \\
\text { (97.5 to }\end{array}$ & 24 & $\begin{array}{l}142.7 \\
\text { (112.3 to }\end{array}$ & 0.417 \\
\hline
\end{tabular}




\begin{tabular}{|c|c|c|c|c|c|c|}
\hline \multirow[t]{3}{*}{ Variable } & \multicolumn{2}{|c|}{ Low Protein } & \multicolumn{2}{|c|}{ High Protein } & \multirow[t]{2}{*}{ Control } & \multirow[t]{3}{*}{$P$-value* } \\
\hline & $\begin{array}{l}\text { Low glycemic } \\
\text { index }\end{array}$ & $\begin{array}{l}\text { High glycemic } \\
\text { index }\end{array}$ & $\begin{array}{l}\text { Low glycemic } \\
\text { index }\end{array}$ & $\begin{array}{l}\text { High glycemic } \\
\text { index }\end{array}$ & & \\
\hline & $\begin{array}{ll}N \quad \text { Mean } \\
\\
\quad(95 \% \mathrm{Cl})\end{array}$ & $\begin{array}{ll}N \quad \text { Mean } \\
\\
(95 \% \mathrm{Cl})\end{array}$ & $\begin{array}{ll}N \quad \text { Mean } \\
\\
(95 \% \mathrm{Cl})\end{array}$ & $\begin{array}{ll}N \quad \text { Mean } \\
\\
(95 \% \mathrm{Cl})\end{array}$ & $\begin{array}{ll}N \quad \text { Mean } \\
\\
(95 \% \mathrm{Cl})\end{array}$ & \\
\hline \multicolumn{7}{|c|}{ Energy and macronutrient intake } \\
\hline & 156.3) & 171.4) & 125.0) & 154.7) & 173.0) & \\
\hline
\end{tabular}

\section{Fiber (g/day)}

\begin{tabular}{|c|c|c|c|c|c|c|c|c|c|c|c|}
\hline At baseline & 46 & $\begin{array}{l}19.9 \\
(17.7 \text { to } \\
22.1)\end{array}$ & 52 & $\begin{array}{l}17.0 \\
(14.8 \text { to } \\
19.1)\end{array}$ & 50 & $\begin{array}{l}19.0 \\
(16.9 \text { to } \\
21.1)\end{array}$ & 49 & $\begin{array}{l}17.7 \\
(15.5 \text { to } \\
20.1)\end{array}$ & 47 & $\begin{array}{l}18.3 \\
(16.1 \text { to } \\
20.6)\end{array}$ & 0.371 \\
\hline At week 4 & 38 & $\begin{array}{l}25.6 \\
(21.8 \text { to } \\
29.4)\end{array}$ & 49 & $\begin{array}{l}22.7 \\
(19.7 \text { to } \\
25.7)\end{array}$ & 48 & $\begin{array}{l}21.2 \\
(19.2 \text { to } \\
23.3)\end{array}$ & 52 & $\begin{array}{l}20.0 \\
(17.8 \text { to } \\
22.2)\end{array}$ & 46 & $\begin{array}{l}22.8 \\
(20.6 \text { to } \\
25.0)\end{array}$ & 0.051 \\
\hline At week 26 & 27 & $\begin{array}{l}29.0 \\
(25.4 \text { to } \\
32.7)\end{array}$ & 30 & $\begin{array}{l}23.4 \\
(19.2 \text { to } \\
27.6)\end{array}$ & 40 & $\begin{array}{l}22.3 \\
(18.9 \text { to } \\
25.6)\end{array}$ & 35 & $\begin{array}{l}20.2 \\
(17.5 \text { to } \\
22.9)\end{array}$ & 33 & $\begin{array}{l}22.7 \\
(20.0 \text { to } \\
25.3)\end{array}$ & 0.007 \\
\hline At week 52 & 21 & $\begin{array}{l}22.0 \\
(18.9 \text { to } \\
25.0)\end{array}$ & 15 & $\begin{array}{l}21.7 \\
(15.5 \text { to } \\
28.0)\end{array}$ & 27 & $\begin{array}{l}22.4 \\
(18.8 \text { to } \\
25.9)\end{array}$ & 22 & $\begin{array}{l}21.0 \\
(15.8 \text { to } \\
26.3)\end{array}$ & 24 & $\begin{array}{l}23.8 \\
(19.8 \text { to } \\
27.7)\end{array}$ & 0.912 \\
\hline
\end{tabular}

* $P$ value for one-way ANOVA 
Supplementary information Table 3 Changes in body composition (mean and 95\% confidence interval) from post-LCD to the end of the 12 months randomized diet period in the completers $(N=139)$.

\begin{tabular}{|c|c|c|c|c|c|c|}
\hline Variable & Low P/Low GI & Low P/High GI & High P/Low GI & High P/High GI & Control & $P$ value* \\
\hline Fat-free mass (kg) & $\begin{array}{l}2.4 \\
(1.5 \text { to } 3.3)\end{array}$ & $\begin{array}{l}2.8 \\
(1.7 \text { to } 3.9)\end{array}$ & $\begin{array}{l}3.3 \\
(2.4 \text { to } 4.2)\end{array}$ & $\begin{array}{l}2.4 \\
(1.3 \text { to } 3.5)\end{array}$ & $\begin{array}{l}2.7 \\
(1.7 \text { to } 3.7)\end{array}$ & 0.932 \\
\hline Fat mass (kg) & $\begin{array}{l}2.6 \\
(0.5 \text { to } 4.8)\end{array}$ & $\begin{array}{l}2.1 \\
(-0.5 \text { to } 4.7)\end{array}$ & $\begin{array}{l}1.5 \\
(-0.7 \text { to } 3.7)\end{array}$ & $\begin{array}{l}0.6 \\
(-1.9 \text { to } 3.1)\end{array}$ & $\begin{array}{l}0.6 \\
(-1.8 \text { to } 2.9)\end{array}$ & 0.235 \\
\hline $\begin{array}{l}\text { Waist circumfer- } \\
\text { ence }(\mathrm{cm})\end{array}$ & $\begin{array}{l}6.8 \\
(3.4 \text { to } 10.2)\end{array}$ & $\begin{array}{l}5.4 \\
(1.7 \text { to } 9.1)\end{array}$ & $\begin{array}{l}4.4 \\
(1.0 \text { to } 7.7)\end{array}$ & $\begin{array}{l}3.4 \\
(0.1 \text { to } 6.7)\end{array}$ & $\begin{array}{l}4.7 \\
(1.2 \text { to } 8.3)\end{array}$ & 0.753 \\
\hline $\begin{array}{l}\text { Hip circumference } \\
(\mathrm{cm})\end{array}$ & $\begin{array}{l}5.0 \\
(2.4 \text { to } 7.6)\end{array}$ & $\begin{array}{l}4.0 \\
(1.2 \text { to } 6.8)\end{array}$ & $\begin{array}{l}3.4 \\
(0.9 \text { to } 5.8)\end{array}$ & $\begin{array}{l}2.2 \\
(-0.2 \text { to } 4.6)\end{array}$ & $\begin{array}{l}3.4 \\
(0.8 \text { to } 6.0)\end{array}$ & 0.774 \\
\hline $\begin{array}{l}\text { Sagittal diameter } \\
(\mathrm{cm})\end{array}$ & $\begin{array}{l}1.3 \\
\text { (0.3 to } 2.3)\end{array}$ & $\begin{array}{l}1.6 \\
(0.5 \text { to } 2.7)\end{array}$ & $\begin{array}{l}0.8 \\
(-0.2 \text { to } 1.8)\end{array}$ & $\begin{array}{l}0.7 \\
(-0.4 \text { to } 1.7)\end{array}$ & $\begin{array}{l}0.8 \\
(-0.2 \text { to } 1.9)\end{array}$ & 0.531 \\
\hline
\end{tabular}

* $P$ value for one-way ANOVA 
Supplementary information Table 4 Changes in metabolic and cardiovascular risk factors (mean and $95 \%$ confidence interval) from post-LCD to the end of the 12 months randomized diet period in the completers ( $\mathrm{N}$ = 139).

\begin{tabular}{|c|c|c|c|c|c|c|}
\hline Variable & Low P/Low GI & Low P/High GI & High P/Low GI & High P/High GI & Control & $P$ value* \\
\hline $\begin{array}{l}\text { Systolic blood } \\
\text { pressure }(\mathrm{mmHg})\end{array}$ & $\begin{array}{l}8.5 \\
\text { (3.3 to } 13.6)\end{array}$ & $\begin{array}{l}7.9 \\
(2.3 \text { to } 13.5)\end{array}$ & $\begin{array}{l}6.9 \\
(1.6 \text { to } 12.1)\end{array}$ & $\begin{array}{l}4.3 \\
(-0.7 \text { to } 9.3)\end{array}$ & $\begin{array}{l}6.0 \\
(0.7 \text { to } 11.4)\end{array}$ & 0.801 \\
\hline $\begin{array}{l}\text { Diastolic blood } \\
\text { pressure }(\mathrm{mmHg})\end{array}$ & $\begin{array}{l}4.5 \\
(0.7 \text { to } 8.2)\end{array}$ & $\begin{array}{l}7.5 \\
\text { (3.5 to } 11.6)\end{array}$ & $\begin{array}{l}4.5 \\
\text { (0.7 to } 8.3)\end{array}$ & $\begin{array}{l}4.0 \\
(0.4 \text { to } 7.6)\end{array}$ & $\begin{array}{l}6.0 \\
(2.2 \text { to } 9.9)\end{array}$ & 0.490 \\
\hline $\begin{array}{l}\text { Total cholesterol } \\
\text { (mmol/L) }\end{array}$ & $\begin{array}{l}1.1 \\
\text { (0.8 to } 1.4)\end{array}$ & $\begin{array}{l}1.5 \\
\text { (1.2 to } 1.8)\end{array}$ & $\begin{array}{l}1.5 \\
\text { (1.2 to } 1.9)\end{array}$ & $\begin{array}{l}1.0 \\
(0.7 \text { to } 1.3)\end{array}$ & $\begin{array}{l}1.3 \\
\text { (0.9 to } 1.6)\end{array}$ & 0.043 \\
\hline $\mathrm{HDL}(\mathrm{mmol} / \mathrm{L})$ & $\begin{array}{l}0.3 \\
(0.2 \text { to } 0.4)\end{array}$ & $\begin{array}{l}0.1 \\
(0.0 \text { to } 0.3)\end{array}$ & $\begin{array}{l}0.4 \\
(0.3 \text { to } 0.5)\end{array}$ & $\begin{array}{l}0.3 \\
(0.2 \text { to } 0.4)\end{array}$ & $\begin{array}{l}0.2 \\
(0.0 \text { to } 0.3)\end{array}$ & 0.157 \\
\hline $\mathrm{LDL}(\mathrm{mmol} / \mathrm{L})$ & $\begin{array}{l}0.7 \\
(0.4 \text { to } 1.0)\end{array}$ & $\begin{array}{l}1.2 \\
\text { (0.9 to } 1.5)\end{array}$ & $\begin{array}{l}1.0 \\
(0.7 \text { to } 1.3)\end{array}$ & $\begin{array}{l}0.6 \\
(0.3 \text { to } 0.9)\end{array}$ & $\begin{array}{l}1.0 \\
(0.7 \text { to } 1.3)\end{array}$ & 0.002 \\
\hline $\begin{array}{l}\text { Triglycerides } \\
(\mathrm{mmol} / \mathrm{L})\end{array}$ & $\begin{array}{l}0.3 \\
(0.1 \text { to } 0.5)\end{array}$ & $\begin{array}{l}0.4 \\
(0.2 \text { to } 0.6)\end{array}$ & $\begin{array}{l}0.4 \\
(0.2 \text { to } 0.6)\end{array}$ & $\begin{array}{l}0.2 \\
(0.0 \text { to } 0.5)\end{array}$ & $\begin{array}{l}0.2 \\
(0.0 \text { to } 0.4)\end{array}$ & 0.883 \\
\hline $\begin{array}{l}\text { Adiponectin } \\
(\mu \mathrm{g} / \mathrm{mL})\end{array}$ & $\begin{array}{l}3.9 \\
(2.5 \text { to } 5.3)\end{array}$ & $\begin{array}{l}3.2 \\
(1.7 \text { to } 4.7)\end{array}$ & $\begin{array}{l}3.0 \\
(1.6 \text { to } 4.4)\end{array}$ & $\begin{array}{l}2.9 \\
(1.4 \text { to } 4.4)\end{array}$ & $\begin{array}{l}2.5 \\
(1.1 \text { to } 4.0)\end{array}$ & 0.365 \\
\hline CRP (mg/L) & $\begin{array}{l}0.0 \\
(-1.1 \text { to } 1.1)\end{array}$ & $\begin{array}{l}-0.1 \\
(-1.2 \text { to } 1.0)\end{array}$ & $\begin{array}{l}0.3 \\
(-0.7 \text { to } 1.4)\end{array}$ & $\begin{array}{l}-0.1 \\
(-1.2 \text { to } 0.9)\end{array}$ & $\begin{array}{l}0.3 \\
(-0.8 \text { to } 1.5)\end{array}$ & 0.413 \\
\hline $\begin{array}{l}\text { Fasting glucose } \\
\text { (mmol/L) }\end{array}$ & $\begin{array}{l}0.6 \\
(0.4 \text { to } 0.8)\end{array}$ & $\begin{array}{l}0.5 \\
(0.3 \text { to } 0.7)\end{array}$ & $\begin{array}{l}0.3 \\
\text { (0.1 to } 0.5)\end{array}$ & $\begin{array}{l}0.3 \\
(0.1 \text { to } 0.5)\end{array}$ & $\begin{array}{l}0.3 \\
(0.0 \text { to } 0.5)\end{array}$ & 0.091 \\
\hline $\begin{array}{l}\text { Fasting insulin } \\
\text { (mlU/L) }\end{array}$ & $\begin{array}{l}1.6 \\
\text { (-0.5 to } 3.7 \text { ) }\end{array}$ & $\begin{array}{l}2.4 \\
\text { (0.1 to } 4.6)\end{array}$ & $\begin{array}{l}3.1 \\
\text { (1.0 to } 5.1)\end{array}$ & $\begin{array}{l}1.3 \\
(-0.9 \text { to } 3.5)\end{array}$ & $\begin{array}{l}0.9 \\
(-1.0 \text { to } 2.9)\end{array}$ & 0.557 \\
\hline $\begin{array}{l}\text { Fructosamine } \\
(\mu \mathrm{mol} / \mathrm{L})\end{array}$ & $\begin{array}{l}13.0 \\
(2.8 \text { to } 23.2)\end{array}$ & $\begin{array}{l}1.3 \\
(-9.2 \text { to } 11.7)\end{array}$ & $\begin{array}{l}21.9 \\
(11.5 \text { to } 32.3)\end{array}$ & $\begin{array}{l}6.5 \\
(-3.7 \text { to } 16.7)\end{array}$ & $\begin{array}{l}7.9 \\
(-2.5 \text { to } 18.3)\end{array}$ & 0.431 \\
\hline $\begin{array}{l}\text { 2h Glucose } \\
\text { (mmol/L) }\end{array}$ & $\begin{array}{l}-0.4 \\
(-1.3 \text { to } 0.4)\end{array}$ & $\begin{array}{l}-1.3 \\
(-2.3 \text { to }-0.4)\end{array}$ & $\begin{array}{l}-1.3 \\
(-2.2 \text { to }-0.4)\end{array}$ & $\begin{array}{l}-1.4 \\
(-2.3 \text { to }-0.4)\end{array}$ & $\begin{array}{l}-1.0 \\
(-1.9 \text { to }-0.1)\end{array}$ & 0.803 \\
\hline Urea (mmol/L) & $\begin{array}{l}-0.5 \\
(-1.0 \text { to } 0.0)\end{array}$ & $\begin{array}{l}-0.5 \\
(-1.0 \text { to } 0.1)\end{array}$ & $\begin{array}{l}-0.2 \\
(-0.7 \text { to } 0.3)\end{array}$ & $\begin{array}{l}-0.3 \\
(-0.8 \text { to } 0.2)\end{array}$ & $\begin{array}{l}0.0 \\
(-0.5 \text { to } 0.5)\end{array}$ & 0.027 \\
\hline HOMA-IR index & $\begin{array}{l}0.7 \\
(0.2 \text { to } 1.3)\end{array}$ & $\begin{array}{l}0.8 \\
(0.2 \text { to } 1.4)\end{array}$ & $\begin{array}{l}0.9 \\
(0.4 \text { to } 1.4)\end{array}$ & $\begin{array}{l}0.4 \\
(-0.1 \text { to } 1.0)\end{array}$ & $\begin{array}{l}0.6 \\
(0.1 \text { to } 1.1)\end{array}$ & 0.515 \\
\hline HOMA-\%B index & $\begin{array}{l}-53.5 \\
(-121.4 \text { to } 14.4)\end{array}$ & $\begin{array}{l}-22.1 \\
(-95.6 \text { to } 51.3)\end{array}$ & $\begin{array}{l}12.1 \\
(-53.5 \text { to } 77.7)\end{array}$ & $\begin{array}{l}-4.9 \\
(-75.7 \text { to } 65.9)\end{array}$ & $\begin{array}{l}-61.1 \\
(-124.9 \text { to } 2.7)\end{array}$ & 0.596 \\
\hline Matsuda index & $\begin{array}{l}-1.7 \\
(-3.5 \text { to } 0.0)\end{array}$ & $\begin{array}{l}-0.7 \\
(-2.7 \text { to } 1.2)\end{array}$ & $\begin{array}{l}-1.4 \\
(-3.1 \text { to } 0.3)\end{array}$ & $\begin{array}{l}-0.7 \\
(-2.6 \text { to } 1.1)\end{array}$ & $\begin{array}{l}-1.3 \\
(-2.9 \text { to } 0.4)\end{array}$ & 0.856 \\
\hline
\end{tabular}





\title{
CHAPTER 4
}

\section{Evaluation of an 18 months commercial multi- disciplinary obesity treatment programme}

\author{
Submitted
}

Erik E.J.G. Aller Marleen A. van Baak 


\begin{abstract}
Background: The treatment of obesity is an often studied subject. Although reductions in weight and improvements in cardiometabolic risk factors are important aims of obesity treatment, improvements in quality of life and eating behaviour are also relevant outcomes. In this practice based study we evaluated an 18 months commercial multidisciplinary obesity treatment programme and report on treatment results for weight, cardiometabolic risk factors, eating behaviour and quality of life.
\end{abstract}

Methods: From a local commercial obesity treatment center (CO-EUR, Heerlen, The Netherlands) 426 subjects (65\% female; $45.4 \pm 12.2$ y; BMI $40.0 \pm 6.6 \mathrm{~kg} / \mathrm{m}^{2}$ ) were recruited. Measurements of body weight, height, body composition, waist circumference and blood pressure were scheduled at baseline and every 3 months, whereas fasting blood collections (glucose, $\mathrm{HbA1c}$, lipid profile) were scheduled at baseline and every 6 months. At the same time points participants were asked to fill in questionnaires on dietary intake, eating behaviour, and quality of life.

Results: After the 18 months treatment programme, average weight change (mean (95\% confidence interval)) was $-10.9 \mathrm{~kg}(-14.8$ to $-7.0 ; \mathrm{p}<0.001)$ for the completers $(\mathrm{N}=181)$ and $-10.8 \mathrm{~kg}(-14.2$ to $-7.4 ; \mathrm{p}<0.001)$ for the intention-to-treat population $(\mathrm{N}=426)$. Waist circumference (mean \pm SEM) $(-0.13 \pm 0.01 \mathrm{~cm} \quad(p<0.001))$, fat mass ($7.8 \pm 1.3 \mathrm{~kg}(p<0.001))$ systolic $(-11.4 \pm 2.0(p<0.001))$ and diastolic $(-7.0 \pm 1.3(p<0.001))$ blood pressure, triglycerides $(-0.4 \pm 0.1 \quad(p=0.004))$ and plasma glucose $(-0.6 \pm 0.2$ $(p=0.001))$ were significantly reduced. The PCS scale of the SF-36 and all three scales of the TFEQ improved significantly over the 18 months treatment period.

Conclusion: All collected data in this study provides evidence that a multidisciplinary treatment programme based on lifestyle modification, results in significant weight loss and improvements in cardiometabolic risk factors, quality of life and eating behaviour. 


\section{Introduction}

Obesity is a multi-factorial disease. It is associated with numerous co-morbidities ranging from high blood pressure to cancer and joint issues (1). Physical activity and diet seem to be the two most important actors in the obesity epidemic (2). Weight gain and obesity in free-living populations result from a long-term positive energy balance, where energy intake exceeds energy expenditure (3). The 'obesogenic' environment that we are exposed to makes it easy to consume a lot of calorie dense food and reduce energy expenditure to a minimum (4). There is also growing evidence that psychological problems play an important role in the development and maintenance of obesity (5). Binge eating disorder or disturbed eating habits are quite common among people who suffer from obesity. Prevalence rates vary widely from $1 \%$ to $30 \%$ in patients seeking non-surgical weight-loss treatment (6) and $2 \%$ to $49 \%$ in bariatric surgery candidates (7, 8).

Obesity treatment can be divided into surgical and non-surgical treatments. For morbid obesity $\left(\mathrm{BMI}>40 \mathrm{~kg} / \mathrm{m}^{2}\right.$ ), or obesity $\mathrm{BMI}>35 \mathrm{~kg} / \mathrm{m}^{2}$ with high medical risk, surgery is proposed as the most appropriate therapy when all other therapies have been tried, but failed to produce significant weight loss (9). Non-surgical therapies are commonly used for obese individuals with a BMI $<40 \mathrm{~kg} / \mathrm{m}^{2}$. Non-surgical treatments include drug treatment, increased physical activity, nutritional advice (diet) or psychological counselling / behaviour therapy. Combinations of these therapies are usually most effective (10). Results for these conventional treatments vary widely and are often related to how motivated the individuals are $(11,12)$. Most therapies succeed in achieving significant weight loss in motivated individuals. However, weight regain often ensues (13). Long-term behavioural therapy combined with a diet and physical exercise programme can temper the risk of weight regain after weight loss $(14,15)$. A long-term maintained weight loss of $5-10 \%$ has been shown to be associated with a significant reduction of cardiometabolic risk (16-18).

Where there are a number of reports on the outcome of obesity treatments in primary care $(19,20)$ and well-known commercial weight management programmes like Weight Watchers or Slimming World $(21,22)$, other outpatient commercial programmes have seldomly been evaluated despite the fact that many obese individuals are being treated in such programmes. Local outpatient commercial obesity treatment programmes can provide a solid basis for their patients to stay in contact and provide help also after treatment when needed.

In this practice-based study we evaluated an 18 months commercial multidisciplinary obesity treatment programme and report on treatment results for weight, cardiometabolic risk factors, eating behaviour and quality of life. 


\section{Methods}

\section{Study design and participants}

For this longitudinal study 426 consecutive obese individuals (BMI $\geq 30 \mathrm{~kg} / \mathrm{m}^{2}$, age $\geq 18$ y), who started treatment on a voluntary basis in a local commercial obesity treatment centre (CO-EUR, Heerlen, the Netherlands) between November 2009 and April 2011 and were willing to participate in this study, were recruited. To be admitted to the treatment programme a referral from a general practitioner or medical specialist was required. The participants were enrolled in the CO-EUR treatment programme and most of the data used for this study were routinely collected by CO-EUR. For this study, the centre additionally asked the study participants to fill in questionnaires on food intake, eating behaviour and quality of life. The Medical Ethical Committee of Maastricht University approved the study protocol and informed consent document. All subjects gave written informed consent before being enrolled into the study.

\section{The CO-EUR treatment programme}

The CO-EUR commercial obesity treatment programme was founded in 2008. The programme consisted of an 18-month multi-disciplinary programme targeting lifestyle modification. The programme included a physical activity programme, psychological counselling based on cognitive behavioural therapy (CBT) and nutritional advice to promote a healthy lifestyle. The physical activity consisted of one group sport session (Nordic walking, swimming or medical training therapy) per week and the subjects were encouraged to implement two additional exercise sessions in their weekly routine. The psychological and nutritional group meetings were scheduled once a week initially, with individual meetings every two to four weeks, depending on individual needs. In the course of the program the number and frequency of group meetings was redefined, based on the individual subject's requirements and developments.

\section{Measurements}

Measurements of body weight, height, body composition, waist circumference and blood pressure were scheduled at baseline and every 3 months, whereas fasting blood collections (glucose, $\mathrm{HbA} 1 \mathrm{C}$, lipid profile) were scheduled at baseline and every 6 months. At the same time points participants were asked to fill in the questionnaires (dietary intake, eating behaviour, quality of life). All measurements were performed at 
the treatment centre. The clinical chemistry laboratory of ATRIUM Medical Centre in Heerlen, the Netherlands, performed the biochemical analysis of the blood samples.

Body height was measured with a fixed stadiometer (Seca 222, Hamburg, Germany). Body weight was measured with a digital scale (Omron HBF-500E, Omron Healthcare Europe) to the nearest $0.1 \mathrm{~kg}$. Body composition was determined by bioelectrical impedance analysis (Omron HBF-500E, Omron Healthcare Europe). Waist circumference was measured with a flexible tape (Seca 201, Hamburg, Germany). Blood pressure was measured with a digital blood pressure monitor (Omron M6 Intellisense, Omron Healthcare Europe).

Data on dietary intake were obtained from a food frequency questionnaire that assessed the habitual diet in the previous month. Eating behaviour was assessed by the three factor eating questionnaire (TFEQ) (23). Quality of life was assessed with the SF36 questionnaire (24). We analysed both the physical component summary and the mental component summary scale. These two scales summarize the questionnaire subscales on physical and mental health aspects.

\section{Statistical analysis}

Results are presented as means $\pm S D$, and estimates of effects as means \pm SEM. The primary endpoint was the weight change over the 18 months treatment. The completers analysis involved all subjects that completed the 18-months treatment programme $(\mathrm{N}=181$ ). We used a mixed model analysis to evaluate the weight changes (assessed at 7 different time points during the 18 months treatment). In addition an intention-totreat analysis (ITT) that involved all subjects that were recruited for the study $(\mathrm{N}=426)$ was performed. This analysis assumed that the weight changes in participants who dropped out of the study followed the same course as in the completers from the moment they dropped out. Furthermore, a sensitivity analysis was performed which assumed a return to baseline of body weight at 18 months in participants that had dropped-out of the study. Additional analyses were performed on changes in risk factors and questionnaire outcomes. Significance was set at a $P$ value $<0.05$. Data were analysed with SPSS version 21.0 (IBM, Armonk, NY, USA).

\section{Results}

426 subjects ( 149 male, 277 female, age $45.4 \pm 12.2$ y) were recruited. Their baseline characteristics are shown in table 1.181 of the initial 426 subjects (42\%) completed the 18 months treatment programme. Completers were older $(p<0.001)$ and reported 
a significantly lower energy intake than drop-outs $(p=0.021)$. Drop-outs scored significantly higher on the TFEQ hunger scale than completers $(p=0.011)$ (table 1$)$.

Table 1: Baseline characteristics of all subjects with a comparison between completers and drop-outs. Data are presented as mean (SD)

\begin{tabular}{|c|c|c|c|c|c|}
\hline Variables & N (completers) & $\begin{array}{l}\text { Overall } \\
\text { mean (SD) }\end{array}$ & $\begin{array}{l}\text { Completers } \\
\text { mean (SD) }\end{array}$ & $\begin{array}{l}\text { Drop-outs } \\
\text { mean (SD) }\end{array}$ & p-value* \\
\hline Sex (\% male) & $426(181)$ & 35.0 & 35.4 & 34.7 & 0.887 \\
\hline Age (years) & $426(181)$ & $45.3(12.2)$ & $47.9(12.0)$ & $43.5(12.1)$ & $<0.001$ \\
\hline Weight (kg) & $426(181)$ & $117.4(23.1)$ & $116.7(21.3)$ & $118.0(24.3)$ & 0.554 \\
\hline BMI $\left(\mathrm{kg} / \mathrm{m}^{2}\right)$ & $426(181)$ & $40.0(6.6)$ & $40.1(6.5)$ & $40.0(6.8)$ & 0.927 \\
\hline Waist circumference (m) & $426(181)$ & $1.25(0.16)$ & $1.25(0.16)$ & $1.25(0.16)$ & 0.985 \\
\hline Fat mass (kg) & $390(181)$ & $52.4(12.1)$ & $51.8(11.1)$ & $53.0(12.8)$ & 0.318 \\
\hline $\begin{array}{l}\text { Systolic blood pressure } \\
(\mathrm{mmHg})\end{array}$ & $426(181)$ & 140 (19) & 141.7 (19.5) & $138.7(19.0)$ & 0.119 \\
\hline $\begin{array}{l}\text { Diastolic blood pressure } \\
(\mathrm{mmHg})\end{array}$ & $426(181)$ & $83(11)$ & $84.0(11.1)$ & $82.2(10.1)$ & 0.076 \\
\hline Energy intake (MJ) & $308(140)$ & $12.4(4.7)$ & $11.7(4.7)$ & $13.0(4.8)$ & 0.021 \\
\hline $\begin{array}{l}\text { Carbohydrates (\% of total } \\
\text { energy intake) }\end{array}$ & $308(140$ & $50.1(8.3)$ & $50.4(7.6)$ & $49.8(8.8)$ & 0.564 \\
\hline $\begin{array}{l}\text { Total fats (\% of total energy } \\
\text { intake) }\end{array}$ & $308(140)$ & $32.6(6.7)$ & $32.0(6.6)$ & $33.2(6.8)$ & 0.122 \\
\hline $\begin{array}{l}\text { Protein (\% of total energy } \\
\text { intake) }\end{array}$ & $308(140)$ & $16.5(4.0)$ & $16.7(3.8)$ & $16.4(4.1)$ & 0.465 \\
\hline Fiber (g per day) & $308(140)$ & $29.5(11.7)$ & $29.9(12.0)$ & $29.1(11.4)$ & 0.539 \\
\hline TFEQ_restraint & $310(143)$ & $7.5(3.6)$ & $7.5(3.6)$ & $7.5(3.7)$ & 0.914 \\
\hline TFEQ_disinhibition & $310(143)$ & $6.9(3.0)$ & $6.5(3.0)$ & $7.2(3.0)$ & 0.061 \\
\hline TFEQ_hunger & $310(143)$ & $5.8(3.5)$ & $5.2(3.5)$ & $6.2(3.5)$ & 0.011 \\
\hline SF-36 PCS & 307 (140) & 42.3 (10.9) & 42.1 (10.5) & $42.4(11.2)$ & 0.802 \\
\hline SF-36 MCS & $307(140)$ & $46.6(12.7)$ & $46.4(12.6)$ & $46.7(12.8)$ & 0.821 \\
\hline Total cholesterol (mmol/L) & $413(178)$ & $5.1(1.0)$ & $5.1(1.1)$ & $5.0(1.0)$ & 0.262 \\
\hline $\mathrm{HDL}(\mathrm{mmol} / \mathrm{L})$ & $412(178)$ & $1.3(0.3)$ & $1.3(0.3)$ & $1.3(0.4)$ & 0.882 \\
\hline Ratio total cholesterol-HDL & $412(178)$ & $4.2(1.2)$ & $4.2(1.2)$ & $4.2(1.2)$ & 0.839 \\
\hline LDL (mmol/L) & $412(178)$ & $3.0(0.9)$ & $3.0(1.0)$ & $2.9(0.9)$ & 0.270 \\
\hline Triglycerides (mmol/L) & $413(178)$ & $1.9(1.1)$ & $1.9(1.0)$ & $1.9(1.2)$ & 0.918 \\
\hline Plasma glucose (mmol/L) & $410(176)$ & $6.4(2.1)$ & $6.4(1.9)$ & $6.4(2.3)$ & 0.960 \\
\hline $\mathrm{HbA} 1 \mathrm{C}(\mathrm{mmol} / \mathrm{mol})$ & $412(178)$ & $43.2(14.4)$ & $43.6(13.3)$ & $43.0(15.3)$ & 0.683 \\
\hline
\end{tabular}

* completers vs drop-outs 


\section{Dietary intake}

At baseline, participants reported an energy intake of $12.4 \pm 4.7 \mathrm{MJ}$, which consisted of $50 \pm 8 \%$ of carbohydrate, $33 \pm 7 \%$, protein and $16 \pm 4 \%$ fat (table 1). During treatment energy intake was significantly reduced $(p<0.001)$ and the macronutrient distribution shifted towards an increased protein intake $(p<0.001)$ and a reduced fat intake $(p<$ 0.001 ) with no clear change in carbohydrate intake. There was no significant change in fiber intake (table 2).

Table 2: Estimates of change in dietary intake (mean and SEM) between baseline and 6, 12 and 18 months of treatment

\begin{tabular}{|c|c|c|c|c|c|}
\hline Variables & Number & $\begin{array}{l}\text { Baseline value } \\
\text { mean (SEM) }\end{array}$ & $\begin{array}{l}\text { Time point } \\
\text { value (SEM) }\end{array}$ & $\begin{array}{l}\text { Mean difference } \\
\text { (SEM) }\end{array}$ & p-value* \\
\hline \multicolumn{6}{|c|}{ Energy intake (MJ per day) } \\
\hline 6 months & 171 & $12.6(0.4)$ & $7.9(0.2)$ & $-4.6(0.4)$ & $<0.001$ \\
\hline 12 months & 106 & $12.3(0.5)$ & $7.1(0.2)$ & $-5.2(0.5)$ & $<0.001$ \\
\hline 18 months & 32 & $12.2(0.9)$ & $7.4(0.3)$ & $-4.8(1.0)$ & $<0.001$ \\
\hline \multicolumn{6}{|c|}{ Carbohydrates (\% of total energy intake) } \\
\hline 6 months & 171 & $49.6(0.6)$ & $52.1(0.5)$ & $2.5(0.8)$ & 0.003 \\
\hline 12 months & 106 & $49.0(0.9)$ & $51.0(0.7)$ & $2.0(1.1)$ & 0.081 \\
\hline 18 months & 32 & $51.2(1.4)$ & $53.5(1.4)$ & $2.2(2.0)$ & 0.276 \\
\hline \multicolumn{6}{|c|}{ Total fats (\% of total energy intake) } \\
\hline 6 months & 171 & $32.7(0.6)$ & $24.8(0.4)$ & $-7.9(0.7)$ & $<0.001$ \\
\hline 12 months & 106 & $32.7(0.8)$ & $25.7(0.5)$ & $-6.9(0.9)$ & $<0.001$ \\
\hline 18 months & 32 & $31.6(1.5)$ & $24.8(1.1)$ & $-6.8(1.8)$ & 0.001 \\
\hline \multicolumn{6}{|c|}{ Protein (\% of total energy intake) } \\
\hline 6 months & 171 & $16.4(0.3)$ & $22.3(0.3)$ & $5.9(0.5)$ & $<0.001$ \\
\hline 12 months & 106 & $17.3(0.4)$ & $22.2(0.4)$ & $4.9(0.6)$ & $<0.001$ \\
\hline 18 months & 32 & $16.2(0.7)$ & $21.0(0.7)$ & $4.7(1.0)$ & $<0.001$ \\
\hline \multicolumn{6}{|c|}{ Fiber (g per day) } \\
\hline 6 months & 171 & $30.0(0.9)$ & $30.3(0.8)$ & $0.2(1.2)$ & 0.844 \\
\hline 12 months & 106 & $29.9(1.3)$ & $27.1(1.0)$ & $-2.7(1.6)$ & 0.092 \\
\hline 18 months & 32 & $33.9(2.2)$ & $29.3(1.7)$ & $-4.5(2.8)$ & 0.116 \\
\hline
\end{tabular}

* $p$ value for comparison between baseline and time point 


\section{Body weight}

Average weight change over the 18 months treatment programme was $-10.9 \mathrm{~kg}(-14.8$ to $-7.0 ; p<0.001)$ for the completers and $-10.8 \mathrm{~kg}(-14.2$ to $-7.4 ; p<0.001)$ for the intention-to-treat population (table 3 ). We additionally performed a sensitivity analysis in which we assumed that drop-outs returned to their baseline weight after dropping-out. This analysis resulted in a $-4.6 \mathrm{~kg}(-7.4$ to $-1.9 ; p=0.001)$ weight change over the 18 months treatment period. Figure 1 shows the body weight changes over the 18 months treatment period for these 3 analyses.

Table 3: Estimates of change in body weight (mean and 95\% confidence interval) between baseline and 18 months of treatment

\begin{tabular}{llll}
\hline Variable & Number & Change in body weight $(\mathbf{k g})$ & P-value \\
\hline Completers analysis & 181 & $-10.9(-14.8$ to -7.0$)$ & $<0.001$ \\
Intention-to-treat analysis & 426 & $-10.8(-14.2$ to -7.4$)$ & $<0.001$ \\
Sensitivity BCF analysis & 426 & $-4.6(-7.4$ to -1.9$)$ & 0.001 \\
\hline
\end{tabular}

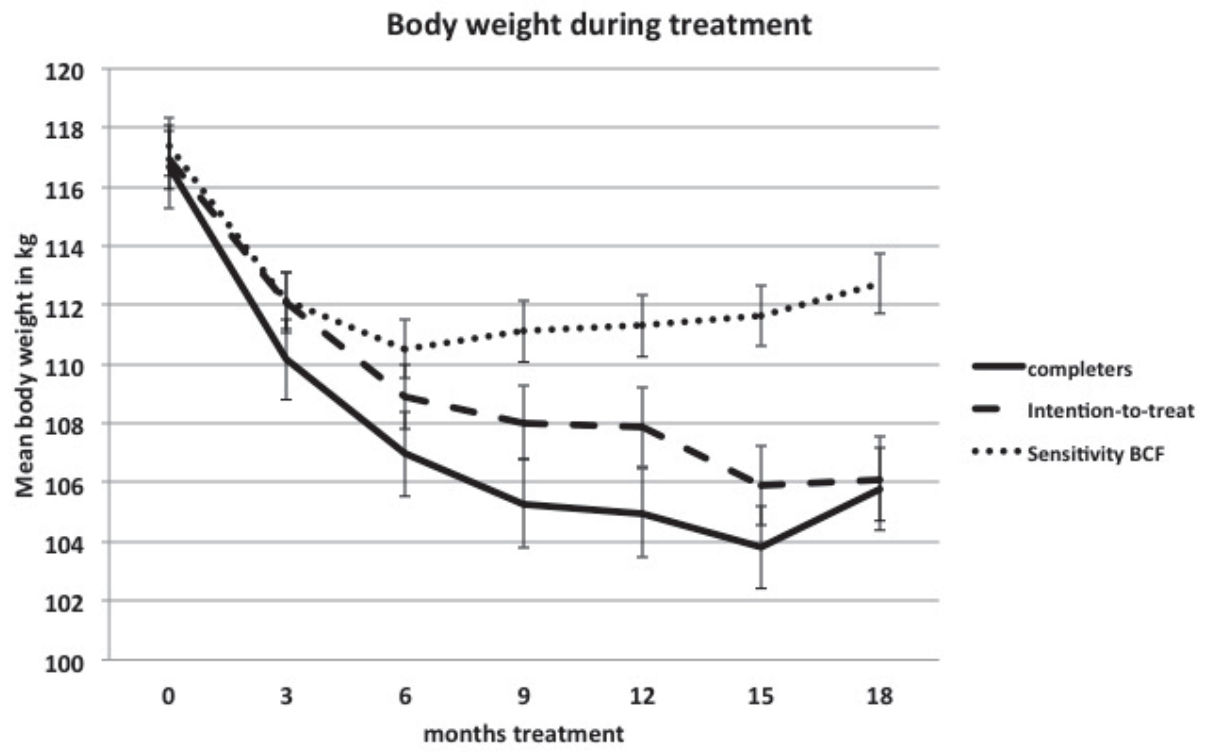

Figure 1: Body weight changes (SEM) in the completers, the ITT population and sensitivity analysis with Baseline Carried Forward over the 18 months treatment. 


\section{Body composition}

Waist circumference and fat mass both showed a highly significant improvement during the whole treatment period resulting in a $-0.13 \pm 0.01 \mathrm{~cm}(p<0.001)$ in waist circumference and $-7.8 \pm 1.3 \mathrm{~kg}(p<0.001)$ in fat mass after 18 months of treatment (table 4).

Table 4: Estimates of change in body composition (mean and SEM) between baseline and 6, 12 and 18 months of treatment

\begin{tabular}{|c|c|c|c|c|c|}
\hline \multirow{2}{*}{$\begin{array}{l}\text { Variables } \\
B M I\left(\mathrm{~kg} / \mathrm{m}^{2}\right)\end{array}$} & \multirow[t]{2}{*}{ Number } & \multirow[t]{2}{*}{$\begin{array}{l}\text { Baseline value } \\
\text { mean (SEM) }\end{array}$} & \multicolumn{2}{|c|}{$\begin{array}{l}\text { Time point valueMean difference (SEM) } \\
\text { (SEM) }\end{array}$} & \multirow[t]{2}{*}{ p-value* } \\
\hline & & & & & \\
\hline 6 months & 309 & $40.1(0.4)$ & $37.1(0.3)$ & $-3.0(0.5)$ & $<0.001$ \\
\hline 12 months & 235 & $40.2(0.4)$ & $36.7(0.4)$ & $-3.5(0.6)$ & $<0.001$ \\
\hline 18 months & 181 & $39.8(0.5)$ & $36.1(0.5)$ & $-3.7(0.7)$ & $<0.001$ \\
\hline \multicolumn{6}{|c|}{ Waist circumference (m) } \\
\hline 6 months & 309 & $1.25(0.01)$ & $1.16(0.01)$ & $-0.09(0.01)$ & $<0.001$ \\
\hline 12 months & 235 & $1.26(0.01)$ & $1.14(0.01)$ & $-0.12(0.01)$ & $<0.001$ \\
\hline 18 months & 181 & $1.25(0.01)$ & $1.12(0.01)$ & $-0.13(0.01)$ & $<0.001$ \\
\hline \multicolumn{6}{|c|}{ Fat mass ( $k g)$} \\
\hline 6 months & 302 & $52.5(0.7)$ & $46.0(0.7)$ & $-6.5(1.0)$ & $<0.001$ \\
\hline 12 months & 227 & $52.4(0.8)$ & $43.8(0.8)$ & $-8.6(1.2)$ & $<0.001$ \\
\hline 18 months & 181 & $51.4(0.9)$ & $43.6(1.0)$ & $-7.8(1.3)$ & $<0.001$ \\
\hline
\end{tabular}

* p value for comparison between baseline and time point

\section{Cardiometabolic risk factors}

Systolic and diastolic blood pressure showed a significant reduction at every time point over the whole 18 months treatment period ( $p<0.001$ ). There were no significant improvements in cholesterol except for total cholesterol and ratio total cholesterol - HDL in the first 6 months ( $p=0.005$ and $p=0.040$ respectively) (table 5). Triglycerides on the other hand were significantly lowered at all 3 time points $(p<0.005)$. Plasma glucose was significantly reduced at $6(p<0.001)$ and 18 months $(p=0.001)$, with a trend at 12 months $(p=0.054)$, and $\mathrm{HbA1c}$ was significantly reduced at 6 months of treatment only (table 5). 
Table 5: Estimates of change in cardiometabolic risk factors (mean and SEM) between baseline and 6, 12 and 18 months of treatment

\begin{tabular}{|c|c|c|c|c|c|}
\hline Variables & Number & $\begin{array}{l}\text { Baseline value } \\
\text { mean (SEM) }\end{array}$ & $\begin{array}{l}\text { Time point value } \\
\text { (SEM) }\end{array}$ & $\begin{array}{l}\text { Mean difference } \\
\text { (SEM) }\end{array}$ & p-value* \\
\hline \multicolumn{6}{|c|}{ Total cholesterol (mmol/L) } \\
\hline 6 months & 269 & $5.1(0.06)$ & $4.9(0.06)$ & $-0.2(0.09)$ & 0.005 \\
\hline 12 months & 209 & $5.1(0.07)$ & $5.0(0.07)$ & $-0.1(0.1)$ & 0.272 \\
\hline 18 months & 116 & $5.2(0.1)$ & $5.1(0.09)$ & $-0.1(0.1)$ & 0.156 \\
\hline \multicolumn{6}{|c|}{ HDL cholesterol ( $\mathrm{mmol} / \mathrm{L})$} \\
\hline 6 months & 269 & $1.3(0.02)$ & $1.3(0.02)$ & $0.0(0.02)$ & 0.651 \\
\hline 12 months & 209 & $1.2(0.02)$ & $1.3(0.02)$ & $0.1(0.03)$ & 0.106 \\
\hline 18 months & 116 & $1.3(0.03)$ & $1.3(0.03)$ & $0.0(0.04)$ & 0.107 \\
\hline \multicolumn{6}{|c|}{ Ratio total cholesterol - HDL cholesterol } \\
\hline 6 months & 269 & $4.3(0.07)$ & $4.1(0.07)$ & $-0.2(0.1)$ & 0.040 \\
\hline 12 months & 209 & $4.3(0.08)$ & $4.1(0.09)$ & $-0.2(0.1)$ & 0.057 \\
\hline 18 months & 116 & $4.3(0.1)$ & $4.0(0.1)$ & $-0.3(0.2)$ & 0.053 \\
\hline \multicolumn{6}{|c|}{ LDL cholesterol (mmol/L) } \\
\hline 6 months & 269 & $3.0(0.06)$ & $2.9(0.06)$ & $-0.1(0.08)$ & 0.217 \\
\hline 12 months & 209 & $2.9(0.06)$ & $2.9(0.06)$ & $0.0(0.09)$ & 0.765 \\
\hline 18 months & 115 & $3.1(0.08)$ & $3.0(0.08)$ & $-0.1(0.1)$ & 0.643 \\
\hline \multicolumn{6}{|c|}{ Triglycerides ( $\mathrm{mmol} / \mathrm{L})$} \\
\hline 6 months & 269 & $1.8(0.06)$ & $1.5(0.05)$ & $-0.3(0.08)$ & $<0.001$ \\
\hline 12 months & 209 & $2.0(0.08)$ & $1.6(0.06)$ & $-0.4(0.1)$ & $<0.001$ \\
\hline 18 months & 116 & $2.0(0.1)$ & $1.6(0.1)$ & $-0.4(0.1)$ & 0.004 \\
\hline \multicolumn{6}{|c|}{ Glucose $(\mathrm{mmol} / \mathrm{L})$} \\
\hline 6 months & 269 & $6.4(0.1)$ & $5.9(0.09)$ & $-0.5(0.1)$ & $<0.001$ \\
\hline 12 months & 209 & $6.6(0.1)$ & $6.2(0.2)$ & $-0.4(0.2)$ & 0.054 \\
\hline 18 months & 115 & $6.3(0.1)$ & $5.7(0.1)$ & $-0.6(0.2)$ & 0.001 \\
\hline \multicolumn{6}{|c|}{$\mathrm{HbA1c}(\mathrm{mmol} / \mathrm{mol})$} \\
\hline 6 months & 269 & $43.4(0.8)$ & $40.4(0.7)$ & $-3.0(1.0)$ & 0.004 \\
\hline 12 months & 208 & $45.1(1.1)$ & $42.9(0.9)$ & $-2.2(1.5)$ & 0.128 \\
\hline 18 months & 117 & $42.9(1.0)$ & $40.8(0.8)$ & $-2.1(1.3)$ & 0.105 \\
\hline \multicolumn{6}{|c|}{ Systolic blood pressure $(\mathrm{mmHg})$} \\
\hline 6 months & 309 & $141.6(1.0)$ & $129.1(0.9)$ & $-12.5(1.4)$ & $<0.001$ \\
\hline 12 months & 235 & $142.0(1.2)$ & $128.7(1.2)$ & $-13.3(1.7)$ & $<0.001$ \\
\hline 18 months & 181 & $141.6(1.4)$ & $130.2(1.4)$ & $-11.4(2.0)$ & $<0.001$ \\
\hline \multicolumn{6}{|c|}{ Diastolic blood pressure $(\mathrm{mmHg})$} \\
\hline 6 months & 309 & $83.9(0.6)$ & $77.7(0.6)$ & $-6.1(0.9)$ & $<0.001$ \\
\hline 12 months & 235 & $83.9(0.7)$ & $76.8(0.8)$ & $-7.1(1.0)$ & $<0.001$ \\
\hline 18 months & 181 & $83.7(0.9)$ & $76.7(1.0)$ & $-7.0(1.3)$ & $<0.001$ \\
\hline
\end{tabular}

$*$ p value for comparison between baseline and time point 
Quality of life and eating behaviour

With respect to quality of life, only the physical component summary scale showed a significant improvement over the whole 18 months treatment period. The mental component summary scale did not change significantly (table 6). All three scales of the Three Factor Eating Questionnaire (TFEQ) (restrained eating, disinhibition and hunger) significantly improved on all measured time points during the 18 months treatment (table 6).

Table 6: Estimates of change in SF-36 and TFEQ questionnaire scores (mean and SEM) between baseline and 6, 12 and 18 months of treatment

\begin{tabular}{|c|c|c|c|c|c|}
\hline Variables & Number & $\begin{array}{l}\text { Baseline value } \\
\text { mean (SEM) }\end{array}$ & $\begin{array}{l}\text { Time point value } \\
\text { (SEM) }\end{array}$ & $\begin{array}{l}\text { Mean } \\
\text { difference (SEM) }\end{array}$ & p-value* \\
\hline \multicolumn{6}{|c|}{ Physical component summary } \\
\hline 6 months & 177 & $42.6(0.9)$ & $47.1(0.8)$ & $4.5(1.2)$ & $<0.001$ \\
\hline 12 months & 121 & $40.9(1.1)$ & $47.3(1.0)$ & $6.4(1.5)$ & $<0.001$ \\
\hline 18 months & 42 & $43.1(1.7)$ & $49.0(1.6)$ & $5.9(2.4)$ & 0.015 \\
\hline \multicolumn{6}{|c|}{ Mental component summary } \\
\hline 6 months & 177 & $48.6(0.9)$ & $50.9(0.8)$ & $2.3(1.2)$ & 0.063 \\
\hline 12 months & 121 & $48.0(1.2)$ & $50.0(1.0)$ & $2.0(1.6)$ & 0.197 \\
\hline 18 months & 42 & $46.0(2.3)$ & $51.6(1.8)$ & $5.6(2.9)$ & 0.063 \\
\hline \multicolumn{6}{|c|}{ TFEQ cognitive restrained eating } \\
\hline 6 months & 159 & $7.5(0.3)$ & $11.1(0.2)$ & $3.6(0.4)$ & $<0.001$ \\
\hline 12 months & 108 & $7.6(0.4)$ & $11.2(0.3)$ & $3.6(0.5)$ & $<0.001$ \\
\hline 18 months & 37 & $8.0(0.6)$ & $11.1(0.4)$ & $3.1(0.7)$ & $<0.001$ \\
\hline \multicolumn{6}{|c|}{ TFEQ disinibition } \\
\hline 6 months & 159 & $6.5(0.2)$ & $4.9(0.2)$ & $-1.6(0.3)$ & $<0.001$ \\
\hline 12 months & 108 & $6.3(0.3)$ & $4.5(0.3)$ & $-1.8(0.2)$ & $<0.001$ \\
\hline 18 months & 37 & $6.6(0.5)$ & $4.7(0.4)$ & $-1.9(0.6)$ & 0.004 \\
\hline \multicolumn{6}{|l|}{ TFEQ hunger } \\
\hline 6 months & 159 & $5.5(0.3)$ & $2.5(0.2)$ & $-3.0(0.3)$ & $<0.001$ \\
\hline 12 months & 108 & $5.0(0.3)$ & $2.3(0.2)$ & $-2.6(0.4)$ & $<0.001$ \\
\hline 18 months & 37 & $5.0(0.6)$ & $1.6(0.2)$ & $-3.3(0.6)$ & $<0.001$ \\
\hline
\end{tabular}

* p value for comparison between baseline and time point 


\section{Discussion}

The results of this 18-month commercial multidisciplinary treatment programme based on lifestyle modification indicate that it is possible to achieve an acceptable weight reduction $( \pm 9 \%)$ with improvements in cardiometabolic risk factors, quality of life and eating behaviour in (mostly severely) obese individuals. The subjects that completed the 18 months treatment programme had an average weight change of $-10.9 \mathrm{~kg}(-14.8$ to $-7.0 ; p<0.001)$ compared to $-10.8 \mathrm{~kg}(-14.2$ to $-7.4 ; p<0.001)$ for the intention-totreat population. With the conservative BCF sensitivity analysis assuming that drop-outs returned to their baseline weight this analysis still predicted a $-4.6 \mathrm{~kg}(-7.4$ to $-1.9 ; \mathrm{p}=$ 0.001 ) weight change after 18 months of treatment in the whole cohort.

The strength of this treatment programme lies in the combination of behavioural therapy based on CBT with nutritional advice and physical activity. Behavioural therapy has been shown to be an important factor in obesity treatment based on lifestyle modification (15). The psychologists involved in this treatment programme do not only treat the eating disorder or the disturbed eating behaviour, but also the psychological problems that might lie at the basis of the disturbed eating behaviour.

When looking solely at the weight reduction, the results of this programme are more favourable or similar to those of other large scale studies on commercial or primary care programmes based on lifestyle modification (19-22, 25, 26). Standard primary care results appear to be the least favourable: in a large RCT by Jebb et al., obese individuals who were referred to a commercial programme by their primary care provider lost twice as much weight as those obtaining standard primary care over 12 months (20). After 24 months the difference between the two groups was smaller, although it was still in favour of the group that had participated in the commercial treatment programme, despite the fact that those participants had regained more weight (19). The Swedish commercial weight loss program "Itrim" obtained a weight loss of $-10.9 \pm 7.5 \mathrm{~kg}$ after 12 months (25). Slimming World has reported a weight loss of $9.6 \mathrm{~kg}$ after 6 months (22). Evaluation of the Jenny Craig programme showed a weight loss of $7.3 \pm 10.4 \mathrm{~kg}$ at 12 months (26). The Weight Watchers programme produced a $6.0 \pm 0.8 \mathrm{~kg}$ weight loss at 48 weeks (21).

A modest weight loss of $5-10 \%$ of total body weight, produces health benefits with respect to blood pressure, blood lipids and blood sugar (27). Over the years, this has become a well-established finding in (lifestyle based) weight loss interventions $(17,18)$, and our findings in this study are in line with this except for cholesterol. The effect on risk factor profile is likely to be underestimated by our data, because we did not correct for changes in medication during treatment. Many participants were on antihypertensive, glucose-lowering and/or lipid-lowering drugs at the start of treatment and prescriptions were decreased during the treatment based on changes in these risk factors. Information about changes in medication were not available, but it can be speculated that these changes have affected the findings on changes in risk factors. 
Although modest weight loss of 5-10\% produces these benefits, greater long-term weight loss is often recommended in patients with $\mathrm{BMI}>35 \mathrm{~kg} / \mathrm{m}^{2}$. The European Clinical Practice Guidelines recommend > 20\% weight loss (28), in Germany the objective of obesity treatment is a long-term weight reduction of $>10 \%(29)$ and recent recommendations of the Scottish Intercollegiate Guidelines Network (SIGN) state that in many patients with $\mathrm{BMI}>35 \mathrm{~kg} / \mathrm{m}^{2}$ a greater than $15-20 \%$ weight loss will be required to obtain a sustained improvement in comorbidity (30). At baseline, $75 \%$ of the completers had a $\mathrm{BMI}>35 \mathrm{~kg} / \mathrm{m}^{2}$. Of these, $40 \%$ achieved a weight loss $>10 \%, 20 \%$ achieved > $15 \%$ weight loss and only $12 \%$ had more than $20 \%$ weight loss after 18 months of treatment (supplementary figure 1).

The dietary advice given in the CO-EUR programme is based on a healthy balanced diet of $40-60 \%$ carbohydrate, $20-30 \%$ fat and $20-30 \%$ protein without the use of meal replacement products. Recommended caloric intake was estimated based on age, gender and body height. Self-reported dietary intakes were in agreement with these recommendations at all timepoints. The large scale Diogenes trial has shown that an ad libitum diet with a comparable reduced fat and increased dietary protein content has a favourable effect on weight regain after initial weight loss (31).

Although reductions in weight and improvements in cardiometabolic risk factors are important aims of obesity treatment, improvements in quality of life and eating behaviour are also relevant outcomes (32). Quality of life is an important indicator in self perceived health (33) and obesity is associated with decreased quality of life (34). Recent studies have shown significant improvements in quality of life after intensive lifestyle interventions, as measured by both the PCS and the MCS scale of the SF-36 (35, 36). Warkentin et al. state that, to achieve the minimally clinical important difference of 3-5 scale points on the PCS and MCS scale, a weight loss of $>20 \%$ would be more appropriate than the commonly cited $5 \%$ threshold in severely obese individuals (37). Nevertheless, our 18 months results show a significant improvement of 5.9 scale points in PCS and a trend for improvement in MCS (5.6 scale points, $p=0.063$ ) with an average weight loss of $9 \%$.

Eating behaviour as assessed by the three factor eating questionnaire produced highly significant improvements on the restrained eating, disinhibition and hunger scores in the first 6 months and these improvements were maintained over the course of the 18 months treatment. The CBT used by the psychologists in the programme treats the disturbed eating behaviour, which results in more restrained eating and less disinhibition (38). The previously addressed increased protein intake may also have contributed to the reduced feeling of hunger, because proteins provide a more satiating effect than fats or carbohydrates $(39,40)$.

The strength of this study is that it is a practice-oriented study. It shows what can be achieved with commercial obesity treatment in mostly severely obese individuals. Obviously, such practice-oriented study also has limitations. Drop-out rates are known to be a major problem when analysing data from obesity treatments in a real-life set- 
ting (ranging form $10 \%$ to $80 \%(41)$ ) compared to well-controlled scientific studies (42). In our study the financial burden of the treatment (which is non-existent in a clinical trial) was an important factor for drop-out. Participants in the treatment programme were committed to paying $€ 50$,- per month. The region in which the treatment centre is located is a rather low-SES region and for participants with a low SES, the financial contribution to the treatment can be quite a burden. Moreover, not all participants showed up at planned measurements, which accounted for missing data. The high drop-out rate and missing data at different time points during the treatment may have affected the power of our analyses. We therefore used a mixed model analysis as proposed in the literature (43) and analysed the data in three different ways (completers, ITT and sensitivity analysis). Also, some data, like information on prescription medication were not systematically registered and can therefore not be used properly in the analysis. The study was not designed as a randomized clinical trial and therefore no control group was included. We can therefore only compare our data with similar studies that did use a control group (15). These studies show an average weight loss of $1 \mathrm{~kg}$ over 12 months in the control group.

In conclusion, our data show that an 18-month multidisciplinary commercial treatment programme based on lifestyle modification, results in significant weight loss and improvements in cardiometabolic risk factors, quality of life and eating behaviour in mostly severely obese individuals.

\section{Conflicts of interest}

The authors declare no conflicts of interest.

\section{Acknowledgements}

EA carried out the study, performed the analyses and wrote the manuscript. MvB provided the idea for the study and improved the manuscript.

\section{References}

1. Skolnik NS, Ryan DH. Pathophysiology, epidemiology, and assessment of obesity in adults. The Journal of family practice. 2014;63(7):S3-S10.

2. Redinger RN. The prevalence and etiology of nongenetic obesity and associated disorders. South Med J. 2008;101(4):395-9.

3. Sinha A, Kling S. A review of adolescent obesity: prevalence, etiology, and treatment. Obes Surg. 2009;19(1):113-20. 
4. Kirk SF, Penney TL, McHugh TL. Characterizing the obesogenic environment: the state of the evidence with directions for future research. Obesity reviews : an official journal of the International Association for the Study of Obesity. 2010;11(2):109-17.

5. Williamson DA, Martin CK, Stewart T. Psychological aspects of eating disorders. Best practice \& research Clinical gastroenterology. 2004;18(6):1073-88.

6. Dingemans $A E$, Bruna MJ, van Furth EF. Binge eating disorder: a review. International journal of obesity and related metabolic disorders : journal of the International Association for the Study of Obesity. 2002;26(3):299-307.

7. Mitchell JE, Lancaster KL, Burgard MA, Howell LM, Krahn DD, Crosby RD, et al. Long-term follow-up of patients' status after gastric bypass. Obesity surgery. 2001;11(4):464-8.

8. Burgmer R, Grigutsch K, Zipfel S, Wolf AM, de Zwaan M, Husemann B, et al. The influence of eating behavior and eating pathology on weight loss after gastric restriction operations. Obesity surgery. 2005;15(5):684-91.

9. Piche ME, Auclair A, Harvey J, Marceau S, Poirier P. How to Choose and Use Bariatric Surgery in 2015. The Canadian journal of cardiology. 2015;31(2):153-66.

10. Kushner RF, Sur DK. Principles and nonpharmacologic management of obesity in adults. The Journal of family practice. 2014;63(7):S15-20.

11. Armstrong MJ, Mottershead TA, Ronksley PE, Sigal RJ, Campbell TS, Hemmelgarn BR. Motivational interviewing to improve weight loss in overweight and/or obese patients: a systematic review and metaanalysis of randomized controlled trials. Obesity reviews : an official journal of the International Association for the Study of Obesity. 2011;12(9):709-23.

12. Cox ME, Yancy WS, Jr., Coffman CJ, Ostbye T, Tulsky JA, Alexander SC, et al. Effects of counseling techniques on patients' weight-related attitudes and behaviors in a primary care clinic. Patient education and counseling. 2011;85(3):363-8.

13. Jensen MD, Ryan DH, Apovian CM, Ard JD, Comuzzie AG, Donato KA, et al. 2013 AHA/ACC/TOS guideline for the management of overweight and obesity in adults: a report of the American College of Cardiology/American Heart Association Task Force on Practice Guidelines and The Obesity Society. Circulation. 2014;129(25 Suppl 2):S102-38.

14. Dombrowski SU, Knittle K, Avenell A, Araujo-Soares V, Sniehotta FF. Long term maintenance of weight loss with non-surgical interventions in obese adults: systematic review and meta-analyses of randomised controlled trials. Bmj. 2014;348:g2646.

15. Hartmann-Boyce J, Johns DJ, Jebb SA, Aveyard P, Behavioural Weight Management Review G. Effect of behavioural techniques and delivery mode on effectiveness of weight management: systematic review, meta-analysis and meta-regression. Obesity reviews : an official journal of the International Association for the Study of Obesity. 2014;15(7):598-609.

16. Wing RR. Long-term effects of a lifestyle intervention on weight and cardiovascular risk factors in individuals with type 2 diabetes mellitus: four-year results of the Look AHEAD trial. Archives of internal medicine. 2010;170(17):1566-75.

17. Wing RR, Bolin P, Brancati FL, Bray GA, Clark JM, Coday M, et al. Cardiovascular effects of intensive lifestyle intervention in type 2 diabetes. The New England journal of medicine. 2013;369(2):145-54.

18. Ryan D, Heaner M. Guidelines (2013) for managing overweight and obesity in adults. Preface to the full report. Obesity. 2014;22 Suppl 2:S1-3.

19. Holzapfel C, Cresswell L, Ahern AL, Fuller NR, Eberhard M, Stoll J, et al. The challenge of a 2-year followup after intervention for weight loss in primary care. International journal of obesity. 2014;38(6):806-11.

20. Jebb SA, Ahern AL, Olson AD, Aston LM, Holzapfel C, Stoll J, et al. Primary care referral to a commercial provider for weight loss treatment versus standard care: a randomised controlled trial. Lancet. 2011;378(9801):1485-92.

21. Pinto AM, Fava JL, Hoffmann DA, Wing RR. Combining behavioral weight loss treatment and a commercial program: a randomized clinical trial. Obesity. 2013;21(4):673-80. 
22. Stubbs RJ, Brogelli DJ, Pallister CJ, Whybrow S, Avery AJ, Lavin JH. Attendance and weight outcomes in 4754 adults referred over 6 months to a primary care/commercial weight management partnership scheme. Clinical obesity. 2012;2(1-2):6-14.

23. Stunkard AJ, Messick S. The three-factor eating questionnaire to measure dietary restraint, disinhibition and hunger. Journal of psychosomatic research. 1985;29(1):71-83.

24. Ware JE, Jr., Gandek B. Overview of the SF-36 Health Survey and the International Quality of Life Assessment (IQOLA) Project. Journal of clinical epidemiology. 1998;51(11):903-12.

25. Hemmingsson E, Johansson K, Eriksson J, Sundstrom J, Neovius M, Marcus C. Weight loss and dropout during a commercial weight-loss program including a very-low-calorie diet, a low-calorie diet, or restricted normal food: observational cohort study. The American journal of clinical nutrition. 2012;96(5):953-61.

26. Rock CL, Pakiz B, Flatt SW, Quintana EL. Randomized trial of a multifaceted commercial weight loss program. Obesity. 2007;15(4):939-49.

27. Blackburn G. Effect of degree of weight loss on health benefits. Obesity research. 1995;3 Suppl 2:211s-6s.

28. Tsigos C, Hainer V, Basdevant A, Finer N, Fried M, Mathus-Vliegen E, et al. Management of obesity in adults: European clinical practice guidelines. Obesity facts. 2008;1(2):106-16.

29. Wirth $A$, Wabitsch $M$, Hauner $H$. The prevention and treatment of obesity. Deutsches Arzteblatt international. 2014;111(42):705-13.

30. SIGN. Management of obesity; A national clinical guideline [pdf document]. 2010 [cited 2015 march 6]. Available from: http://www.sign.ac.uk/pdf/sign115.pdf.

31. Astrup A, Raben A, Geiker N. The role of higher protein diets in weight control and obesity-related comorbidities. International journal of obesity. 2014.

32. Lasikiewicz N, Myrissa K, Hoyland A, Lawton CL. Psychological benefits of weight loss following behavioural and/or dietary weight loss interventions. A systematic research review. Appetite. 2014;72:123-37.

33. Wang JJ, Smith W, Cumming RG, Mitchell P. Variables determining perceived global health ranks: findings from a population-based study. Annals of the Academy of Medicine, Singapore. 2006;35(3):190-7.

34. Ul-Haq Z, Mackay DF, Fenwick E, Pell JP. Impact of metabolic comorbidity on the association between body mass index and health-related quality of life: a Scotland-wide cross-sectional study of 5,608 participants. BMC public health. 2012;12:143.

35. Danielsen KK, Sundgot-Borgen J, Maehlum S, Svendsen M. Beyond weight reduction: improvements in quality of life after an intensive lifestyle intervention in subjects with severe obesity. Annals of medicine. 2014;46(5):273-82.

36. Karlsen TI, Lund RS, Roislien J, Tonstad S, Natvig GK, Sandbu R, et al. Health related quality of life after gastric bypass or intensive lifestyle intervention: a controlled clinical study. Health and quality of life outcomes. 2013;11:17.

37. Warkentin LM, Majumdar SR, Johnson JA, Agborsangaya CB, Rueda-Clausen CF, Sharma AM, et al. Weight loss required by the severely obese to achieve clinically important differences in health-related quality of life: two-year prospective cohort study. BMC medicine. 2014;12:175.

38. Gade H, Hjelmesaeth J, Rosenvinge JH, Friborg O. Effectiveness of a cognitive behavioral therapy for dysfunctional eating among patients admitted for bariatric surgery: a randomized controlled trial. Journal of obesity. 2014;2014:127936.

39. Belza A, Ritz C, Sorensen MQ, Holst JJ, Rehfeld JF, Astrup A. Contribution of gastroenteropancreatic appetite hormones to protein-induced satiety. The American journal of clinical nutrition. 2013;97(5):9809.

40. Maersk M, Belza A, Holst JJ, Fenger-Gron M, Pedersen SB, Astrup A, et al. Satiety scores and satiety hormone response after sucrose-sweetened soft drink compared with isocaloric semi-skimmed milk and with non-caloric soft drink: a controlled trial. European journal of clinical nutrition. 2012;66(4):523-9.

41. Moroshko I, Brennan L, O'Brien P. Predictors of dropout in weight loss interventions: a systematic review of the literature. Obesity reviews : an official journal of the International Association for the Study of Obesity. 2011;12(11):912-34. 
42. Dalle Grave R, Calugi S, Molinari E, Petroni ML, Bondi M, Compare A, et al. Weight loss expectations in obese patients and treatment attrition: an observational multicenter study. Obesity research. 2005;13(11):1961-9.

43. Batterham MJ, Tapsell LC, Charlton KE. Analyzing weight loss intervention studies with missing data: which methods should be used? Nutrition. 2013;29(7-8):1024-9. 
Supplementary figure 1 Percentage of completers at 18 months with $\mathrm{BMI}>35 \mathrm{~kg} / \mathrm{m}^{2}$ at baseline displayed in weight loss categories

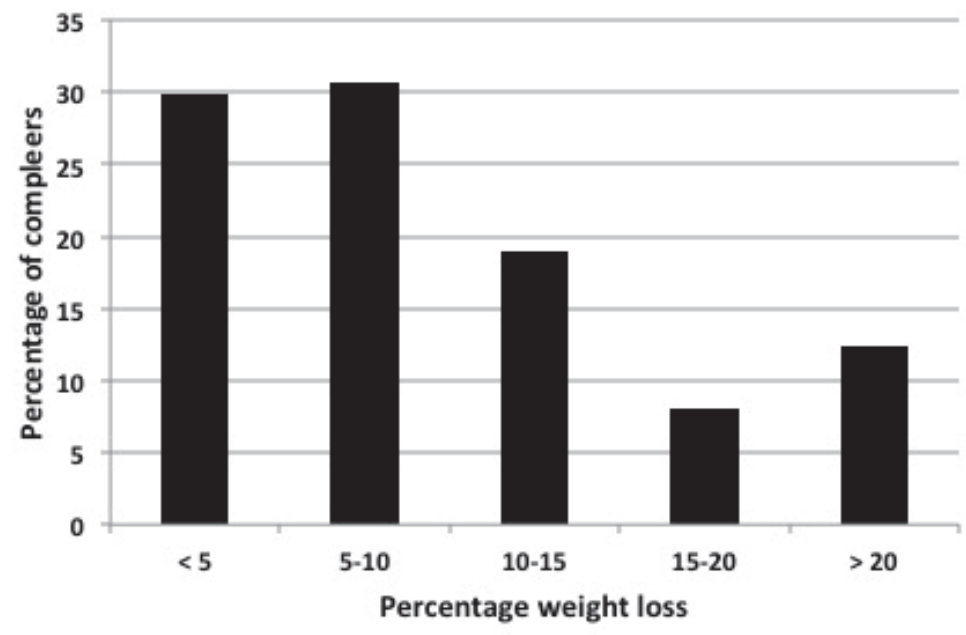




\section{CHAPTER 5}

\section{Physical activity improves glucose tolerance independent of weight loss in severe obesity}

J Diabetes Metab. 2013 Mar;4:254

Erik E.J.G. Aller Marleen A. van Baak 


\begin{abstract}
Background: Impaired glucose tolerance, a risk factor for the development of type 2 diabetes, has a very high prevalence in obese subjects. This study aims to explore the contributions of changes in weight, physical activity (PA), sleep efficiency (SE) and excessive daytime sleepiness (EDS) to changes in glucose tolerance in severely obese subjects during a commercial lifestyle modification programme.
\end{abstract}

Methods: At intake, after 3 and 6 months of treatment, 33 subjects ( $28.2 \%$ male, age: $42.7 \pm 12.3$ years, weight: $118.1 \pm 23.8, \mathrm{BMI}: 40.0 \pm 7.3 \mathrm{~kg} / \mathrm{m}^{2}$ ) were subjected to an oral glucose tolerance test (OGTT), wore an accelerometer for 6 consecutive days and weight and body composition were measured.

Results: After 6 months of treatment there was a significant reduction in weight -11.1 $\mathrm{kg}, \mathrm{BMI}-3.8 \mathrm{~kg} / \mathrm{m}^{2}$, waist circumference $-10.8 \mathrm{~cm}, \%$ Bodyfat $-4.7 \%$ and fat mass $-10.2 \mathrm{~kg}$ (all values $P$ at least $<0.001)$. Glucose tolerance ( $2 \mathrm{~h}$ glucose during OGTT) $(0.8 \mathrm{mmol} / \mathrm{L}$, $\mathrm{P}=0.042)$ ) showed a significant improvement. $\mathrm{PA}, \mathrm{SE}$ and EDS did not change significantly. Changes in weight and PA contributed significantly to the change in glucose tolerance (weight 16\%, P = 0.021; PA 11\%, P=0.049).

Conclusion: We conclude that this commercial lifestyle modification programme significantly reduced weight, waist circumference, \%bodyfat and fat mass and improved glucose tolerance after 3 and 6 months of treatment. The improvement in glucose tolerance was partly explained by the changes in weight and PA, but not by SE or EDS. This study reveals that severely obese subjects benefit from an increase in physical activity independent of weight loss with regard to improvements in glucose tolerance. 


\section{Introduction}

Overweight and obesity present a serious health risk, by increasing the risk of several diseases like type 2 diabetes mellitus and cardiovascular disease (1-3). Reducing the risk of these co-morbidities and maintaining clinically meaningful weight loss should be the goal of any obesity treatment programme. Obesity treatment can consist of an increase in physical activity, reduction of energy intake and/or more healthy eating habits, behavioral change, pharmacological treatment, surgery or a combination of these methods (2-4).

Impaired glucose tolerance, a risk factor for the development of type 2 diabetes, has a high prevalence in obese subjects $(5,6)$. Weight loss, be it by bariatric surgery or by more conservative methods, has been shown to be associated with improvements in glucose tolerance in obese individuals (7-9). In addition, it is well-known that exercise training may improve insulin sensitivity and glucose tolerance (10). Research on this topic has primarily been done in heterogeneous groups, and studies specifically in obese subjects, and even more so in severe obesity, are scarce (11). In recent years, sleep efficiency (SE) and excessive daytime sleepiness (EDS) have been shown to be associated with both glucose tolerance and obesity (12-15). But a clear cause-effect relationship has not yet been established.

The aim of the present study was to explore the independent contributions of changes in weight, physical activity, sleep efficiency and EDS to changes in glucose tolerance in obese subjects during treatment in a commercial lifestyle modification programme.

\section{Methods}

\section{Subjects}

60 subjects from a local commercial obesity treatment centre (CO-EUR, Heerlen, The Netherlands) were recruited. Subjects were at least 18 years old and had a BMI > 30 $\mathrm{kg} / \mathrm{m}^{2}$. Insulin-dependent diabetics and subjects that were not able to participate in the physical activity programme were excluded. The study protocol and informed consent document were approved by the Medical Ethical Committee of Maastricht. All subjects gave written informed consent before being enrolled into the study. 


\section{Study design}

This study was a longitudinal observational study. The researchers did not intervene in the treatment programme performed at the obesity treatment centre. At the start (intake) of the treatment in the obesity treatment centre and after 3 and 6 months of treatment, we performed an oral glucose tolerance test (OGTT), a 6-day physical activity (PA) and sleep measurement and we measured weight, height, waist circumference (WC), percentage body fat (\%BF) and fat mass (FM). Subjects filled out the Epworth Sleepiness Scale (ESS) at intake and at 3 and 6 months.

\section{Measurements}

\section{Oral glucose tolerance test}

A standardized OGTT was performed after an overnight fast. At $t_{0}$ a capillary blood glucose measurement was performed with a capillary blood glucose meter (Ascensia Breeze ${ }^{\oplus}$ meter, Bayer Healthcare LLC). Capillary blood was obtained by finger prick. The results of this blood glucose meter correlate well with laboratory blood glucose measurements $(r=0.97)(16)$. Directly thereafter subjects consumed a standard $300 \mathrm{ml}$ glucose drink containing $75 \mathrm{~g}$ of glucose dissolved in water. During the next 2 hours, the subjects were not allowed to eat, drink or be physically active. Two 2 hours after consumption of the drink $\left(t_{2 h}\right)$ capillary blood glucose was measured again. The capillary glucose concentration 2 hours after ingestion of the glucose drink was used to assess glucose tolerance and its change during treatment.

\section{Anthropometric measurements}

Body height was measured with a fixed stadiometer (Seca 222, Hamburg, Germany). Body weight was measured with a digital scale (Omron HBF-500E, Omron Healthcare Europe) to the nearest $0.1 \mathrm{~kg}$. Body composition was determined by bioelectrical impedance analysis (Omron HBF-500E, Omron Healthcare Europe). Waist circumference was measured with a flexible tape (Seca 201, Hamburg, Germany). 


\section{Physical Activity}

Physical activity was measured during 6 days at each time point. For this measurement we used an uni-axial accelerometric device: the Sensewear Pro 2 Armband (HealthWear Bodymedia, Pittsburgh, PA). The Sensewear Pro 2 armband was positioned around the right upper arm and worn 24 hours per day except during bathing or water activities. Physical activity was described as a minimum of 2 consecutive minutes at $\geq 3$ MET (1 MET (Metabolic Equivalent Task) is the Resting Metabolic Rate (RMR) obtained during quiet sitting. MET values of activities are multiples of RMR and range from 0.9 (sleeping) to 23 (running at $22.5 \mathrm{~km} / \mathrm{h}$ or a $4: 17$ mile pace)(17).

\section{Sleep efficiency}

The Sensewear Pro 2 Armband measures sleep efficiency (SE) by calculating sleep time as percentage of lying down time. Sleep/wake is assessed per minute. In a recent study by O'Driscoll, the authors compared the Senswear Pro 3 with polysomnography (PSG). They conclude that the Sensewear was reliable for determining sleep, but was not reliable for determining wakefulness. This reduces its ability to determine sleep versus wake when SE decreases and thus the SE measurement is less reliable than PSG (18).

\section{Epworth Sleepiness Scale}

The Epworth Sleepiness Scale (ESS) (19) is a simple questionnaire consisting of 8 questions on how likely a person is to fall asleep in 8 different situations. These questions generate a numerical score from zero (0) to 24 . A score below 10 indicates that the person has an average daytime sleep propensity, a score of ten or higher indicates an above normal sleep propensity, which may for instance be related to the presence of sleep apnea.

\section{Obesity treatment programme}

All subjects were enrolled in the commercial obesity treatment programme. This programme consists of an 18-month multi-disciplinary programme targeting lifestyle modification. The programme includes a physical activity programme, psychological counseling and nutritional advice to promote a healthy lifestyle. For the physical activity part there is one group sport session (Nordic walking, swimming or medical training therapy) a week and the subjects are encouraged to implement two additional exercise sessions in their weekly routine. The psychological and nutritional group meetings are 
scheduled once a week initially, with individual meetings every two to four weeks, depending on the individual needs. In the course of the program the number and frequency of the group meetings is redefined, based on the individual subject's requirements and developments.

\section{Statistical analysis}

To analyze the effect of treatment on glucose tolerance, body weight and composition, physical activity and sleep, repeated measures ANCOVA was used. Baseline values were compared to the values after 3 and 6 months of treatment. An explorative stepwise multiple linear regression analysis was performed to elucidate the contributions of changes in body weight, physical activity, sleep efficiency and EDS to the change in glucose tolerance after 6 months. The significance threshold was set at $p \leq .05$.

\section{Results}

At the 6 months measurement there were only 33 subjects left from the initial 60 (Figure 1). The changes over the 3 and 6 months period will be reported for the subjects that did not drop out of the study $(\mathrm{N}=33)$.

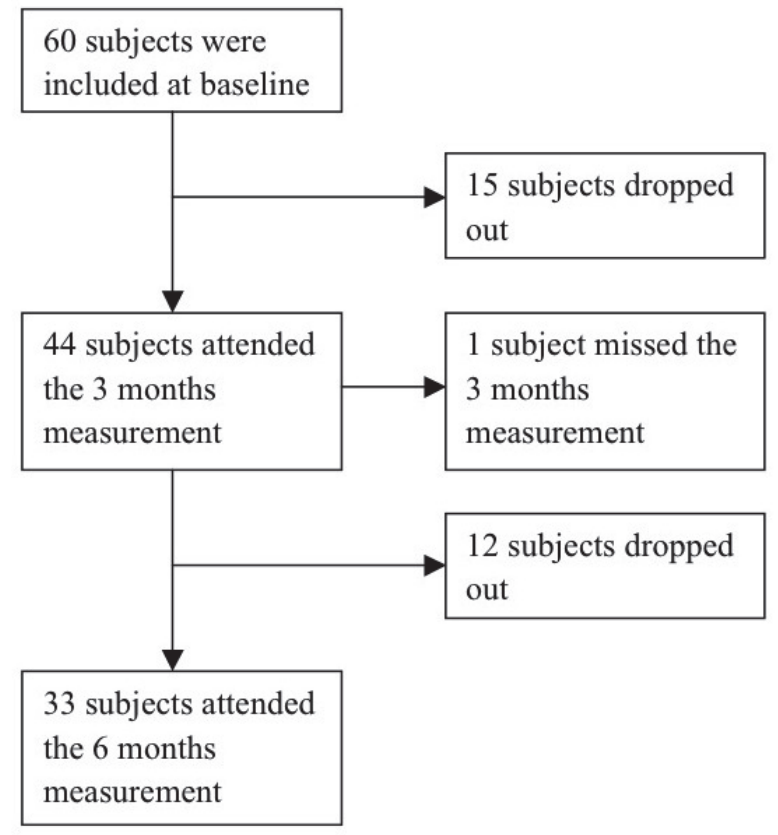

Figure 1: Flowchart of subjects from baseline to 6 months 


\section{Baseline characteristics}

Of these 33 subjects $66.7 \%$ was female. The subjects could be distributed among the following BMI categories: BMI 30-35 (31.3\%); BMI 35-40 (21.9\%); BMI > 40 (46.9\%). $60 \%$ had normal glucose tolerance (NGT) and $40 \%$ had impaired glucose tolerance (IGT). Only 2 of the 60 subjects had an EDS score $\geq 10$. Time spent in light activity ( $>1$ to $<3 \mathrm{MET}$ ) was $288 \pm 97 \mathrm{~min} /$ day, in moderate activity (> 3 to $<6 \mathrm{MET}$ ) was $68 \pm 46$ $\mathrm{min} /$ day and vigorous activity (> $6 \mathrm{MET}$ ) was $1 \pm 3 \mathrm{~min} /$ day.

Mean \pm SD values of the tested variables at baseline can be found in Table 1. No significant differences between completers and drop-outs were found at baseline.

Table 1: Baseline characteristics and changes from baseline after 3 and 6 months of treatment $($ mean $(\mathrm{Cl}$, confidence interval)).

\begin{tabular}{|c|c|c|c|c|c|c|c|}
\hline & & Baseline & & 3 months & & 6 months & \\
\hline Variable & $N$ & Mean $\pm S D$ & $N^{* *}$ & Mean $(\mathrm{Cl})$ & P-value* & Mean $(\mathrm{Cl})$ & $P$-value* \\
\hline Age (years) & 33 & $42.7 \pm 12.3$ & & & & & \\
\hline Height (cm) & 33 & $172 \pm 1.0$ & & & & & \\
\hline Weight (kg) & 33 & $118.1 \pm 23.8$ & 32 & $\begin{array}{l}-8.7 \\
(-10.6 \text { to }-6.7)\end{array}$ & $<0.001$ & $\begin{array}{l}-11.1 \\
(-13.5 \text { to }-8.6)\end{array}$ & $<0.001$ \\
\hline BMI $\left(\mathrm{kg} / \mathrm{m}^{2}\right)$ & 33 & $40.0 \pm 7.3$ & 32 & $\begin{array}{l}-2.9 \\
(-3.6 \text { to }-2.3)\end{array}$ & $<0.001$ & $\begin{array}{l}-3.8 \\
(-4.6 \text { to }-2.9)\end{array}$ & $<0.001$ \\
\hline$W C(\mathrm{~cm})$ & 33 & $124 \pm 15.6$ & 32 & $\begin{array}{l}-6.5 \\
(-7.8 \text { to }-5.1)\end{array}$ & $<0.001$ & $\begin{array}{l}-10.8 \\
(-12.7 \text { to }-8.9)\end{array}$ & $<0.001$ \\
\hline Body fat (\%) & 31 & $46.7 \pm 6.8$ & 29 & $\begin{array}{l}-4.3 \\
(-5.3 \text { to }-3.3)\end{array}$ & $<0.001$ & $\begin{array}{l}-4.7 \\
(-5.9 \text { to }-3.5)\end{array}$ & $<0.001$ \\
\hline Fat mass $(\mathrm{kg})$ & 31 & $54.1 \pm 12.6$ & 29 & $\begin{array}{l}-8.8 \\
(-10.5 \text { to }-7.1)\end{array}$ & $<0.001$ & $\begin{array}{l}-10.2 \\
(-12.3 \text { to }-8.1)\end{array}$ & $<0.001$ \\
\hline $\begin{array}{l}\text { Fasting glucose } \\
(\mathrm{mmol} / \mathrm{L})\end{array}$ & 33 & $5.0 \pm 0.9$ & 31 & $\begin{array}{l}-0.1 \\
(-0.5 \text { to } 0.3)\end{array}$ & 0.648 & $\begin{array}{l}0.6 \\
(0.3 \text { to } 0.8)\end{array}$ & $<0.001$ \\
\hline $\begin{array}{l}\text { 2h glucose } \\
(\mathrm{mmol} / \mathrm{L})\end{array}$ & 33 & $8.2 \pm 3.0$ & 31 & $\begin{array}{l}-1.2 \\
(-2.2 \text { to } 0.2)\end{array}$ & 0.017 & $\begin{array}{l}-0.8 \\
(-1.5 \text { to } 0.0)\end{array}$ & 0.042 \\
\hline SE (\%) & 33 & $81.8 \pm 6.9$ & 27 & $\begin{array}{l}-1.7 \\
(-3.3 \text { to }-0.1)\end{array}$ & 0.035 & $\begin{array}{l}-1.5 \\
(-3.3 \text { to } 0.3)\end{array}$ & 0.095 \\
\hline ESS & 33 & $3.4 \pm 2.7$ & 32 & $\begin{array}{l}-0.3 \\
(-0.8 \text { to } 0.3)\end{array}$ & 0.337 & $\begin{array}{l}-0.5 \\
(-1.1 \text { to } 0.1)\end{array}$ & 0.078 \\
\hline PA (min/day) & 33 & $69 \pm 49$ & 27 & $\begin{array}{l}30 \\
\text { (7 to } 53 \text { ) }\end{array}$ & 0.011 & $\begin{array}{l}9 \\
\text { (-8 to } 26)\end{array}$ & 0.273 \\
\hline
\end{tabular}

* Analysis by repeated measures ANOVA.

** Number of subjects that had baseline, 3 and 6 months measurements for the analyzed variables in the repeated measures ANOVA. 


\section{Post-treatment characteristics}

After 3 months of treatment weight, BMI, WC, \%BF and fat mass (all values $\mathrm{P}$ at least < 0.001 ) were significantly reduced. These improvements were sustained at 6 months (all values $\mathrm{P}$ at least $<0.001)$ ). Glucose tolerance, presented as $2 \mathrm{~h}$ glucose concentration, improved significantly after 3 months and showed a slight rebound at 6 months, but was still significantly improved compared to baseline. At the 3 months OGTT measurement, 4 of the initial 13 IGT subjects transitioned to NGT. This number was unchanged at 6 months.

SE was significantly reduced within the first 3 months compared to baseline. At 6 months this reduction was no longer statistically significant. PA increased after the first 3 months, but this improvement was not seen after 6 months of treatment. The EDS score showed no significant changes (Table 1).

\section{Linear regression analysis}

To explore the independent contributions of the changes in weight, PA, SE and EDS to the changes in $2 \mathrm{~h}$ glucose concentration over the 6 months treatment period, a backward stepwise multiple linear regression analysis was performed.

This resulted in the following final model:

$\Delta_{0-6} 2 \mathrm{~h}$ glucose $($ in $\mathrm{mmol} / \mathrm{L})=$ intercept $+\beta_{1}{ }^{*} \Delta_{0-6}$ weight $($ in $\mathrm{kg})+\beta_{2}{ }^{*} \Delta_{0-6} \mathrm{PA}$ (in $\mathrm{min} / \mathrm{d}$ ), with: intercept $=0.867 ; \beta_{1}=0.390(p=0.021)$ and $\beta_{2}=-0.322(p=0.049)$.

The partial regression plots for changes in weight (Figure 2A) and changes in PA (Figure 2B) show that the changes in weight and PA account for a total of $27 \%$ (weight: $16 \%$; PA: $11 \%$ ) of the variation in the change in $2 \mathrm{~h}$ glucose concentration. Adding the baseline $2 \mathrm{~h}$ glucose value to the model did not influence the outcome. 


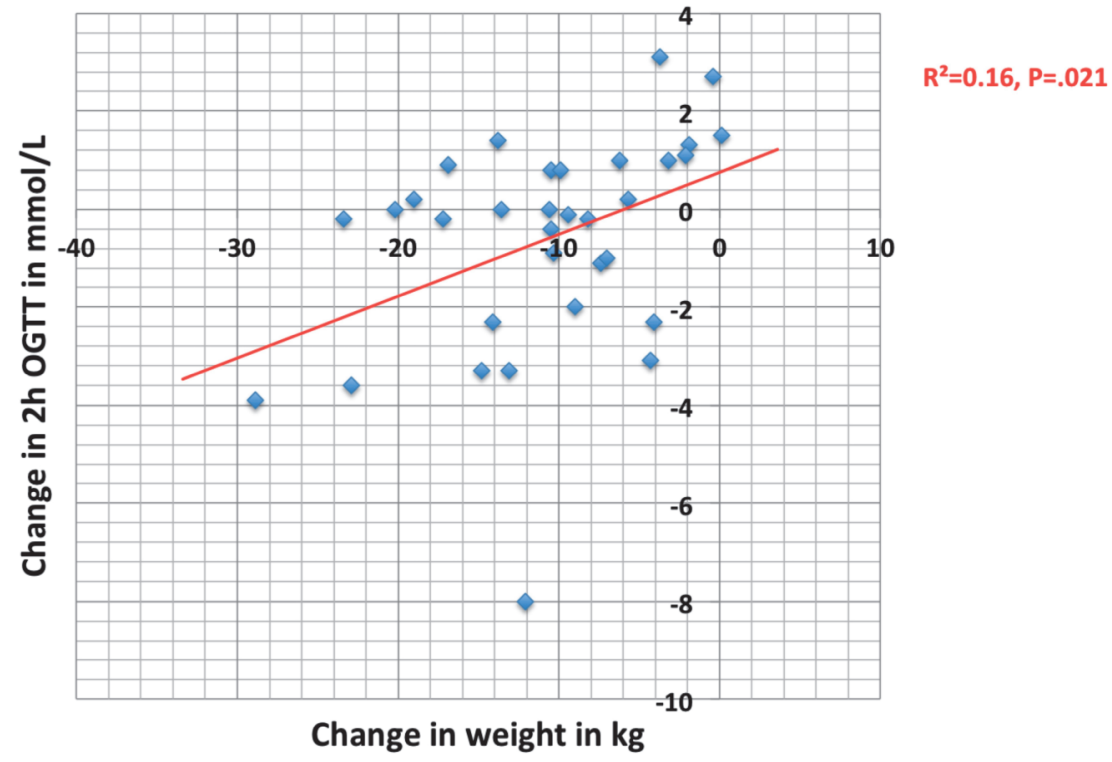

Figure 2A: Partial linear regression plot of the change in $2 \mathrm{~h}$ glucose value and the change in weight.

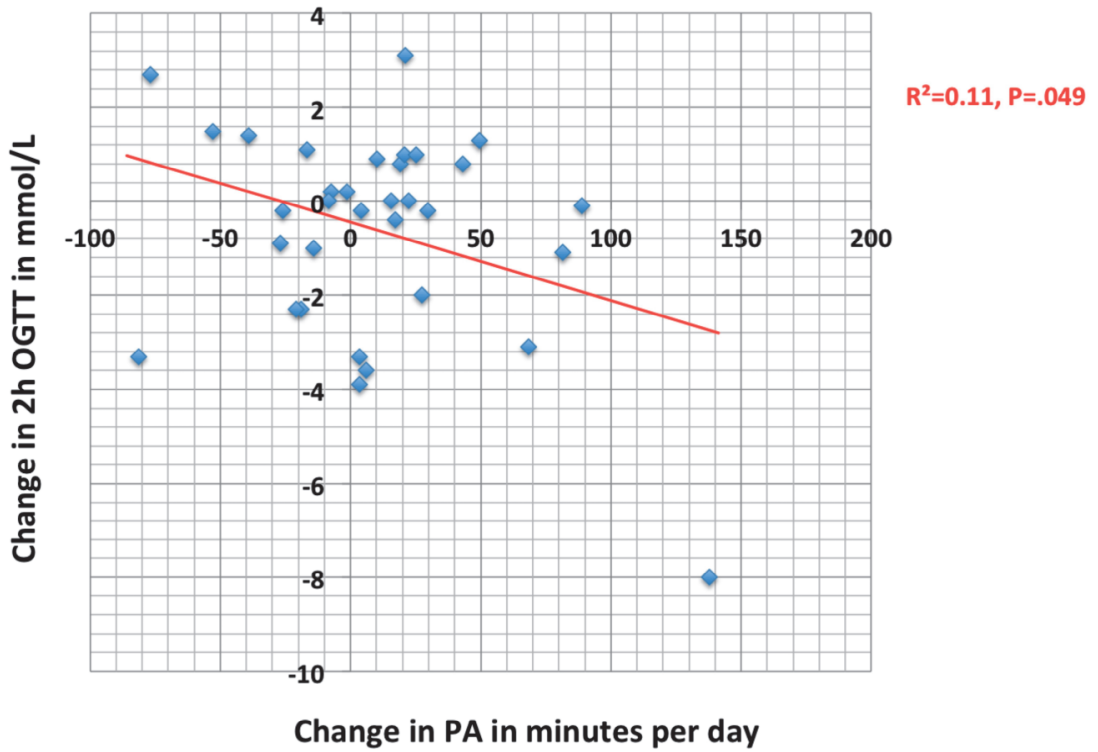

Figure 2B: Partial linear regression plot of the change in $2 \mathrm{~h}$ glucose value and the change in PA. 


\section{Discussion}

This commercial lifestyle modification programme significantly reduced weight, BMI, WC, \%BF and fat mass and improved glucose tolerance after 3 months of treatment. For the anthropometric measurements, further improvements were found at 6 months of treatment. Glucose tolerance did not show further improvements, but was still significantly improved compared to baseline after 6 months. PA significantly increased in the first 3 months, but this increase disappeared again onto the 6 months mark. Sleep efficiency was significantly reduced in the first 3 months but no longer after 6 months of treatment. The main finding of this study was a positive association between the changes in physical activity with the changes in glucose tolerance, independent of changes in weight. We found no association between changes in sleep quantity and quality and changes in glucose tolerance. To date, this is the first study reporting such finding in an extremely obese population.

At baseline, $47 \%$ of the subjects had a BMI $>40 \mathrm{~kg} / \mathrm{m}^{2}$ which makes them eligible for bariatric surgery (20). 40\% had impaired glucose tolerance (IGT). SE at baseline was comparable with reports from other studies in diabetics (12) and moderately obese (15) subjects, with $41 \%$ of our subjects having a SE in the normal range of $>85 \%$. On average, the subjects in our study performed moderate to high intensity (> 3 MET) PA for 69 $\mathrm{min} /$ day. This is considerably less than the moderately obese (BMI approximately 32 $\mathrm{kg} / \mathrm{m}^{2}$ ) subjects in a recent study by Scheers et al (21). These subjects performed 127 $\mathrm{min} /$ day of moderate to high intensity PA (21).

Average percentage weight loss during the first 3 months is higher in our study (7.3\%) compared to large population studies of other commercial treatment programmes (4-5\%) (22-25). Percentage weight loss at 6 months also exceeds previous reports of other commercial treatment programmes $(9.4 \%$ vs. 4.6 to $5.1 \%)(26,27)$. $31 \%$ of the initial 13 IGT subjects transitioned to NGT during the 6 months treatment.

Physical activity (> 3 MET) increased with $30 \mathrm{~min} /$ day in the first 3 months, but at 6 months this increase was only $9 \mathrm{~min} /$ day compared to baseline. When looking at the advice given by the treatment centre ( 1 obligatory and 2 self-implemented exercise sessions per week for an approximate total of 180 minutes), the increase of $30 \mathrm{~min} /$ day in the first 3 months is just above the given advice (180 minutes per week = 26 $\mathrm{min} /$ day). The difference of $9 \mathrm{~min} /$ day at 6 months compared to baseline could mean that the subjects only attended the obligatory exercise session (60 minutes per week = $9 \mathrm{~min} /$ day). The 3 months measurement was mainly done in the summer, whereas the 6 months measurement was executed during winter. Therefore, seasonal variation in leisure time physical activity could also be an explanation for the decrease in PA at the 6 months measurement compared to the 3 months measurement. Data on seasonal variation in PA have been reported by Pivarnik et al. (28). They report that in winter compared to summer, their participants perform fewer exercise sessions per week and the sessions have a shorter duration. 
The most interesting finding of this study was the association between the change in glucose tolerance and the changes in weight and PA, whereas no association with changes in SE or EDS was found.

Previous studies by Katzel et al have shown that weight loss but not aerobic exercise improved glucose tolerance in obese men after 9 months of weight loss vs. exercise (29, 30). Weight loss in these studies was comparable with our findings. There have been studies reporting on exercise-induced improvements in glucose tolerance $(31,32)$. But the subjects in these studies were overweight and had abnormal glucose regulation (32) and/or were at high risk for CVD (31). The results from the above named studies show that weight loss and exercise can independently improve glucose tolerance. But, we did not find a comparable study that shows an independent effect of physical activity on glucose tolerance in a lifestyle modification programme where significant weight loss is achieved in severely obese subjects.

We did not find an association between changes in glucose tolerance and changes in SE or EDS. This may be due to the fact that there was no significant improvement in SE and EDS. EDS was within normal values (score < 10) during the whole study period, we therefore conclude that EDS is not a big issue in this sample. Also, SE was significantly reduced at 3 months compared to baseline. Our hypothesis was that SE would improve with weight loss but maybe the weight loss was not large enough. Kalra et al. (33) found a significant improvement in SE after surgical weight loss of $66.4 \pm 8.8 \mathrm{~kg}$.

This study has some limitations. First we experienced a large drop-out of $45 \%$. This is due to subjects not wanting to continue with the study, but also some subjects dropped out of the treatment programme and were therefore not eligible for inclusion in our study. In 5 subjects PA and SE was not measured correctly, probably because subjects did not clean the electrodes on the device. These electrodes can become obstructed by sebaceous matter and therefore fail to conduct signals from the skin of the arm. When cleaned properly every evening this is no problem, but some subjects forgot to do this. In 3 subjects we were not able to measure \%body fat and fat mass with the bioimpedance scale, because of a \%body fat $>55 \%$, the upper detection limit of the bioimpedance scale. Only 1 subject missed the 3 months measurement, but was present at the 6 month measurement, hence the missing weight, BMI and WC data.

We can conclude that this commercial lifestyle modification programme significantly reduced weight, waist circumference, \%body fat and fat mass and improved glucose tolerance after 3 and 6 months of treatment. The improvement in glucose tolerance was partly explained by the changes in weight and PA, but not by SE or EDS. 


\section{Acknowledgements}

The authors would like to thank Dr. H. Kleinveld from the Atrium MC in Heerlen for the supply of the glucose drinks and Theo van de Kerkhof from APC Cardiovascular for the use of the SenseWear Pro2 Armband.

\section{Conflict of interest}

The authors declare no conflict of interest.

\section{References}

1. Molenaar EA, Numans ME, van Ameijden EJ, Grobbee DE. Aanzienlijke comorbiditeit bij volwassenen met overgewicht: resultaten uit het 'Leidsche Rijn Gezondheidsproject'. Ned Tijdschr Geneeskd. 2008;152(45):2457-63.

2. NIH, NHLaBI, NAASO. The Practical Guide: Identification, Evaluation, and Treatment of Overweight and Obesity in Adults. NIH Publication No 00-4084. 2000.

3. WorldHealthOrganisation. Factsheet: obesity and overweight 2006 [cited 2009 february 24th]. Available from: http://www.who.int/mediacentre/factsheets/fs311/en/index.html.

4. Seidell JC, de Beer JJ, Kuijpers T. Richtlijn 'diagnostiek en behandeling van obesitas bij volwassenen en kinderen'. Ned Tijdschr Geneeskd. 2008;152(38):2071-6.

5. Janssen PG, Gorter KJ, Stolk RP, Rutten GE. Screen detected subjects with type 2 diabetes and impaired glucose tolerance have more adverse cardiovascular risk than subjects with impaired fasting glucose especially when they are obese: the ADDITION Netherlands study. Prim Care Diabetes. 2007;1(2):69-74.

6. Sainaghi PP, Castello L, Bergamasco L, Carnevale Schianca GP, Bartoli E. Metabolic characteristics of glucose intolerance: the critical role of obesity. Exp Clin Endocrinol Diabetes. 2008;116(2):86-93.

7. Tuomilehto J, Lindstrom J, Eriksson JG, Valle TT, Hamalainen H, Ilanne-Parikka P, et al. Prevention of type 2 diabetes mellitus by changes in lifestyle among subjects with impaired glucose tolerance. The New England journal of medicine. 2001;344(18):1343-50.

8. Roumen C, Corpeleijn E, Feskens EJ, Mensink M, Saris WH, Blaak EE. Impact of 3-year lifestyle intervention on postprandial glucose metabolism: the SLIM study. Diabet Med. 2008;25(5):597-605.

9. Rubino F. Bariatric surgery: effects on glucose homeostasis. Current opinion in clinical nutrition and metabolic care. 2006;9(4):497-507.

10. Gill JM. Physical activity, cardiorespiratory fitness and insulin resistance: a short update. Current opinion in lipidology. 2007;18(1):47-52.

11. Katzmarzyk PT, Lear SA. Physical activity for obese individuals: a systematic review of effects on chronic disease risk factors. Obes Rev. 2012;13(2):95-105.

12. Trento M, Broglio F, Riganti F, Basile M, Borgo E, Kucich C, et al. Sleep abnormalities in type 2 diabetes may be associated with glycemic control. Acta Diabetol. 2008;45(4):225-9.

13. Vgontzas AN, Bixler EO, Chrousos GP, Pejovic S. Obesity and sleep disturbances: meaningful sub-typing of obesity. Arch Physiol Biochem. 2008;114(4):224-36.

14. Vgontzas AN, Bixler EO, Chrousos GP. Obesity-related sleepiness and fatigue: the role of the stress system and cytokines. Ann N Y Acad Sci. 2006;1083:329-44.

15. Knutson K, Galli G, Zhao X, Mattingly M, Cizza G, Study NSE. No association between leptin levels and sleep duration or quality in obese adults. Obesity (Silver Spring, Md). 2011;19(2da99800-5044-4d229541-9cd901091470):2433-8. 
16. Garg SK, Carter JA, Mullen L, Folker AC, Parkes JL, Tideman AM. The clinical performance and ease of use of a blood glucose meter that uses a 10-test disk. Diabetes Technol Ther. 2004;6(4):495-502.

17. Ainsworth BE, Haskell WL, Leon AS, Jacobs DR, Jr., Montoye HJ, Sallis JF, et al. Compendium of physical activities: classification of energy costs of human physical activities. Medicine and science in sports and exercise. 1993;25(1):71-80.

18. O'Driscoll DM, Turton AR, Copland JM, Strauss BJ, Hamilton GS. Energy expenditure in obstructive sleep apnea: validation of a multiple physiological sensor for determination of sleep and wake. Sleep \& breathing = Schlaf \& Atmung. 2012.

19. Johns MW. A new method for measuring daytime sleepiness: the Epworth sleepiness scale. Sleep. 1991;14(6):540-5.

20. Picot J, Jones J, Colquitt JL, Gospodarevskaya E, Loveman E, Baxter L, et al. The clinical effectiveness and cost-effectiveness of bariatric (weight loss) surgery for obesity: a systematic review and economic evaluation. Health Technol Assess. 2009;13(41):1-190, 215-357, iii-iv.

21. Scheers T, Philippaerts R, Lefevre J. Patterns of physical activity and sedentary behavior in normal-weight, overweight and obese adults, as measured with a portable armband device and an electronic diary. Clin Nutr. 2012.

22. Stubbs RJ, Pallister C, Whybrow S, Avery A, Lavin J. Weight outcomes audit for 34,271 adults referred to a primary care/commercial weight management partnership scheme. Obesity facts. 2011;4(2):113-20.

23. Lloyd A, Khan R. Evaluation of Healthy Choices: a commercial weight loss programme commissioned by the NHS. Perspectives in public health. 2011;131(4):177-83.

24. Ahern AL, Olson AD, Aston LM, Jebb SA. Weight Watchers on prescription: an observational study of weight change among adults referred to Weight Watchers by the NHS. BMC public health. 2011;11:434.

25. Lavin JH, Avery A, Whitehead SM, Rees E, Parsons J, Bagnall T, et al. Feasibility and benefits of implementing a Slimming on Referral service in primary care using a commercial weight management partner. Public health. 2006;120(9):872-81.

26. Jebb SA, Ahern AL, Olson AD, Aston LM, Holzapfel C, Stoll J, et al. Primary care referral to a commercial provider for weight loss treatment versus standard care: a randomised controlled trial. Lancet. 2011;378(9801):1485-92.

27. Heshka S, Anderson JW, Atkinson RL, Greenway FL, Hill JO, Phinney SD, et al. Weight loss with self-help compared with a structured commercial program: a randomized trial. JAMA : the journal of the American Medical Association. 2003;289(14):1792-8.

28. Pivarnik JM, Reeves MJ, Rafferty AP. Seasonal variation in adult leisure-time physical activity. Medicine and science in sports and exercise. 2003;35(6):1004-8.

29. Katzel LI, Bleecker ER, Colman EG, Rogus EM, Sorkin JD, Goldberg AP. Effects of weight loss vs aerobic exercise training on risk factors for coronary disease in healthy, obese, middle-aged and older men. A randomized controlled trial. JAMA : the journal of the American Medical Association. 1995;274(24):191521.

30. Katzel LI, Bleecker ER, Rogus EM, Goldberg AP. Sequential effects of aerobic exercise training and weight loss on risk factors for coronary disease in healthy, obese middle-aged and older men. Metabolism: clinical and experimental. 1997;46(12):1441-7.

31. Smutok MA, Reece C, Kokkinos PF, Farmer C, Dawson P, Shulman R, et al. Aerobic versus strength training for risk factor intervention in middle-aged men at high risk for coronary heart disease. Metabolism: clinical and experimental. 1993;42(2):177-84.

32. Smutok MA, Reece C, Kokkinos PF, Farmer CM, Dawson PK, DeVane J, et al. Effects of exercise training modality on glucose tolerance in men with abnormal glucose regulation. International journal of sports medicine. 1994;15(6):283-9.

33. Kalra M, Mannaa M, Fitz K, Kumar S, Chakraborty R, Sheng X, et al. Effect of surgical weight loss on sleep architecture in adolescents with severe obesity. Obes Surg. 2008;18(6):675-9. 



\title{
CHAPTER 6
}

Genetic predictors for high weight loss by multidisciplinary advice to severely obese subjects in real-life circumstances

\author{
Submitted
}

Erik E.J.G. Aller

Edwin C.M. Mariman

Freek G. Bouwman Marleen A. van Baak 


\section{Abstract}

Background: Success of losing weight is determined by genetic factors, which may differ according to treatment strategy. Genetic predisposition to weight loss by multidisciplinary treatment involving dietary advice, psychological counseling and increased physical activity has not been studied before.

Methods: From a local commercial obesity treatment center (CO-EUR, Heerlen, The Netherlands) 587 subjects ( $68 \%$ female; $46.1 \pm 12.4$ y; BMI $39.9 \pm 6.3 \mathrm{~kg} / \mathrm{m}^{2}$ ) were recruited. At baseline a blood sample was drawn for isolation of DNA. Genotypes were determined for 30 polymorphisms in 25 candidate genes. At baseline and during the treatment program a body weight measurement was scheduled every 3 months. The association between genotypes, grouped according to the best inheritance model, and weight loss was assessed after 3 months of treatment (short-term) and after 12 months of treatment (long-term). For these analyses weight loss was categorized as $\geq 5 \%$ of initial weight or $<5 \%$ of initial weight.

Results: The G/G genotype of PLIN1 (rs2289487) and PLIN1, (rs2304795) (OR 1.92 and OR 1.75), the T/T genotype of PLIN1 (rs1052700) (OR 1.72) and the C/C genotype of MMP2 (OR 1.83) predicted high weight loss in the first three months. The $C / C$ genotype of PPARG ( $\mathrm{rs} 1801282$ ) and the T/C genotype of TIMP4 (rs3755724) predicted high weight loss after 12 months. Subjects with the C/G-G/G genotype compared to the C/C genotype of PPARG (rs1801282) lost significantly more weight during the 12 month treatment. Subjects with the combination of PPARG (rs1801282) C/G-G/G and TIMP4 (rs3755724) T/C lost even more weight.

Conclusion: Polymorphisms in genes related to regulation of fat storage and structural adaptation of the adipocytes are predictors for weight loss with different genes being relevant for short term and the long term weight loss. Combined genotype analysis shows interaction between the fat storage and adipocyte structural adaptation processes during weight loss. 


\section{Introduction}

Obesity is a multifactorial trait influenced by various environmental factors such as lifestyle and diet, but also by genetic background. Treating people suffering from obesity with lifestyle advice is a challenge, because responses to treatment may vary strongly. Weight loss maintenance and continuation of a modified lifestyle are the greatest challenges, where some turn out to be more successful than others.

In this respect, research has been performed to identify predictors of weight gain, weight loss and weight loss maintenance (1), because those predictors could make obesity treatment more specific for each individual. This revealed the influence of lifestyle-related predictors like initial body weight/BMI, physical activity level and selfmonitoring (2). But also genetic predisposition has been suggested to play a part in this challenge of weight loss and weight maintenance (3) as several gene-loci have been found to be associated with BMI and body weight regulation (4-7). The etiology of obesity is complex and predisposing genes may be involved in various processes ranging from regulation of eating behavior to preadipocyte differentiation and fat storage. Obesity is associated with hypertrophy of adipocytes demanding special adaptation by the extracellular matrix (ECM), the outer protective layer of the cells (8). Therefore, also variation in genes coding for components and modulators of the ECM may contribute to the genetic background for obesity. Notably, the ECM has been proposed to be involved in the creation of adipocyte cell stress during weight loss, providing a risk factor for weight regain $(9,10)$.

From previous studies, we selected 25 candidate genes and gene loci (full list in supplementary table 1), most of which were reported by GWAS analysis (5, 11-13). Beside reported association with BMI or adiposity parameters, selection was based on the function that those genes have in different aspects of weight regulation: storage of fat in the adipocytes (PLIN1, PPARG $(3,4,6,7)$ ), sympathetic regulation of fat storage and release (ADRB2 (14)), formation of the ECM (COL4A1, COL4A2, COL6A1, COL6A2, COL6A3, MMP2, TIMP4 (8)), hypothalamic activity/eating behavior (BNDF, CNTF, FTO, GNDPA2, LEP, MC4R, near TMEM18, SEC16B, SH2B1 $(15,16))$, whole body energy homeostasis (ADIPOQ (17)), weight regain (ACE (18)), and obesity risk in the knock-out mouse (GPRC5B (19)). Variation in these genes was used for analysis of genetic association with 3 and 12 month weight loss in severely obese subjects enrolled in a commercial lifestyle modification program. Our results indicate that some of the gene variants are predictors of weight loss in this lifestyle-treated cohort. 


\section{Methods}

\section{Subjects}

For this study 587 consecutive subjects from a local commercial obesity treatment centre (CO-EUR, Heerlen, The Netherlands, co-eur.com) were recruited. The CO-EUR commercial obesity treatment programme was founded in 2008 and was a unique initiative in the Netherlands. The programme consisted of an 18-month multi-disciplinary programme targeting lifestyle modification. It included a physical activity programme, psychological counselling based on cognitive behavioural therapy (CBT), and nutritional advice to promote a healthy lifestyle. The physical activity consisted of one group sport session (Nordic walking, swimming or medical training therapy) per week and the subjects were encouraged to implement two additional exercise sessions in their weekly routine. The psychological and nutritional group meetings were scheduled once a week initially, with individual meetings every two to four weeks, depending on individual needs. In the course of the program the number and frequency of group meetings was redefined, based on the individual subject's requirements and developments. The goal of the program was to achieve lifestyle modification resulting in long-term weight loss. Subjects were at least 18 years old and had a BMI $>30 \mathrm{~kg} / \mathrm{m}^{2}$. The study protocol and informed consent document were approved by the Medical Ethical Committee of Maastricht University. All subjects gave written informed consent before being enrolled into the study.

\section{Study protocol}

At baseline, before the start of the obesity treatment program, a blood sample was drawn for isolation of DNA. At baseline and during the 18 months treatment program a body weight measurement was scheduled every 3 months. This was performed using a digital scale (Omron HBF-500E, Omron Healthcare Europe) to the nearest $0.1 \mathrm{~kg}$.

\section{DNA isolation and variation selection and genotyping}

Blood was drawn from a forearm vein into an EDTA-containing tube (BD Vacutainer, 10 $\mathrm{ml})$. The buffy coat was obtained by centrifugation $\left(5^{\circ} \mathrm{C}, 3000 \mathrm{rpm}, 10 \mathrm{~min}\right)$ and stored at $-80^{\circ} \mathrm{C}$ until analysis. Genomic DNA was isolated from peripheral blood leukocytes in the buffy coat using a QIAamp kit (QIAgen, Amsterdam, The Netherlands). Genotypes of 25 genes were determined using TaqMan allelic discrimination (Applied Biosystems, Foster City CA, USA) and competitive allele-specific PCR (KASP, LGC, Teddington, UK) by 
Kbioscience (Hoddeston, UK). The full list of the 25 genes with the 30 variation identifiers as well as the allele frequencies and Hardy-Weinberg values (chi-square test) can be found in supplementary table 1. For PLIN1 rs2289487 the results from the genotyping assay were obtained as the forward ' $A$ ' and ' $G$ ' alleles, but in the text we have used the reverse annotation ' $T$ ' and ' $C$ ' in line with previous scientific publications.

\section{Data handling and statistical analysis}

Allelic and genotype frequencies were calculated. All polymorphisms were in HardyWeinberg equilibrium (supplementary table 1). For each variant the best inheritance model was chosen using SNPStats (20). SNPStats is publicly available at http://bioinfo.iconcologia.net/snpstats. The association between genotypes, grouped according to the best inheritance model, and weight loss was assessed after 3 months of treatment $(\mathrm{N}=558)$ and after 12 months $(\mathrm{N}=275)$ of treatment. For these analyses weight loss was categorized as $\geq 5 \%$ of initial weight (high weight loss) or $<5 \%$ of initial weight (low weight loss). This cut-off level was chosen because a $\geq 5 \%$ weight loss is associated with a meaningful improvement of health in obese individuals $(21,22)$. Binary logistic regression analysis was used to determine the odds for $\geq 5 \%$ weight loss of the genotypes. For SNPs of the four genes showing association with $\geq 5 \%$ weight loss, weight loss trajectories over 12 months were calculated and compared by mixed model analysis of variance. For these genes we also analyzed the weight loss trajectories of combinations for two genes comparing the genotypes showing the most beneficial effect on weight loss with all other combinations of the genotypes of the two genes.

For finding relevant associated SNPs, an odds ratio with a 95\% confidence interval deviating from unity and a P-value $<0.05$ was considered as significant. Our final results were checked against a corrected P-value of 0.002 for statistical significance. Statistical analyses were performed using the SPSS v20.0 statistical software (IBM, Armonk, NY, USA).

\section{Results}

\section{Predictors of 3 months of weight loss}

558 out of 587 subjects had a body weight measurement after 3 months of treatment, $336(60 \%)$ had a weight loss $<5 \%$ and $222(40 \%)$ a weight loss $\geq 5 \%$. The high weight loss group was significantly older and had a lower BMI at baseline than the low weight loss group (table 1). Odds ratios for $\geq 5 \%$ weight loss with a $95 \%$ confidence interval deviating from unity were found for 4 SNPs in 2 of the 25 genes (PLIN1 (3 SNPs) and MMP2). 
Subjects with the C/C genotype of PLIN1 rs2289487 were 1.9 times more likely to be in the high weight loss group than subjects with the T/T-T/C genotype (table 2 ). Subjects with the G/G genotype of PLIN1 rs2304795 were 1.8 times more likely to be in the high weight loss group than subjects with the A/A-G/A genotype and subjects with the T/T genotype of PLIN1 rs1052700 were 1.7 times more likely to be in the high weight loss group than subjects with the A/A-T/A genotype (table 2). Furthermore, subjects with the C/C genotype of MMP2 rs1132896 were 1.8 times more likely to be in the high weight loss group than subjects with the G/G-G/C genotype (table 2 ).

Table 1. Baseline characteristics of subjects with $\geq 5 \%$ or $<5 \%$ weight loss at 3 or 12 months.

\begin{tabular}{llll}
\hline $\mathbf{3}$ months & $<\mathbf{5 \%}$ weight loss & $\mathbf{2} \%$ weight loss & $\mathbf{P}_{\text {group }}$ \\
\hline $\mathrm{N}(\%$ male) & $336(32.4)$ & $222(30.2)$ & 0.575 \\
Age & $45.0 \pm 12.7$ & $48.0 \pm 11.7$ & 0.004 \\
BMI & $38.9 \pm 6.4$ & $36.9 \pm 5.7$ & $<0.001$ \\
$\mathbf{1 2}$ months & & & 0.122 \\
$\mathrm{~N}(\%$ male) & $97(28.9)$ & $178(38.2)$ & 0.008 \\
Age & $44.5 \pm 11.6$ & $48.4 \pm 11.7$ & $<0.001$ \\
BMI & $39.9 \pm 6.5$ & $34.4 \pm 5.6$ &
\end{tabular}

Data presented as mean $\pm S D ; P_{\text {group }}$ is the P-value for the difference between the $<5 \%$ and $\geq 5 \%$ weight loss groups.

Table 2. Results of binary logistic regression analysis with 3 and 12 month weight loss as dependent variable ( $<5 \%$ weight loss is reference) and the genotypes as independent variables.

\begin{tabular}{|c|c|c|c|c|}
\hline Gene & rs number & Genotype/Model & $\begin{array}{l}\text { Odds ratio } \\
(95 \% \mathrm{Cl})\end{array}$ & P-value \\
\hline \multicolumn{5}{|l|}{3 months } \\
\hline PLIN1 & rs2289487 & $\mathrm{C} / \mathrm{C}$ vs $\mathrm{T} / \mathrm{T}-\mathrm{T} / \mathrm{C}^{3}$ & $1.92(1.17-3.13)$ & 0.009 \\
\hline PLIN1 & rs2304795 & $G / G$ vs $A / A-G / A^{3}$ & $1.75(1.10-2.79)$ & 0.018 \\
\hline PLIN1 & rs1052700 & $T / T$ vs $A / A-T / A^{3}$ & $1.72(1.04-2.82)$ & 0.033 \\
\hline MMP2 & rs1132896 & $\mathrm{C} / \mathrm{C}$ vs $\mathrm{G} / \mathrm{G}-\mathrm{G} / \mathrm{C}^{3}$ & $1.83(1.13-2.96)$ & 0.014 \\
\hline \multicolumn{5}{|l|}{12 months } \\
\hline PPAR gamma & rs1801282 & $\mathrm{C} / \mathrm{C}$ vs $\mathrm{C} / \mathrm{G}-\mathrm{G} / \mathrm{G}^{1}$ & $2.03(1.07-3.87)$ & 0.025 \\
\hline TIMP4 & rs3755724 & $\mathrm{T} / \mathrm{C}$ vs $\mathrm{C} / \mathrm{C}-\mathrm{T} / \mathrm{T}^{2}$ & $2.03(1.21-3.41)$ & $<0.001$ \\
\hline
\end{tabular}

${ }^{1}$ Dominant; ${ }^{2}$ Overdominant; ${ }^{3}$ Recessive

\section{Predictors of 12 months of weight loss}

275 out of 587 subjects had a valid 12 months measurement. 97 of these subjects (35 $\%)$ had low $(<5 \%)$ weight loss and 178 subjects (65\%) had high $(\geq 5 \%)$ weight loss. The high weight loss group was significantly older and had a lower BMI than the low weight 
loss group (table 1). Odds ratios for $\geq 5 \%$ weight loss with a $95 \%$ confidence interval deviating from unity were found for 2 SNPs in 2 of the 25 genes (PPARG and TIMP4). Subjects with the C/C genotype of PPARG rs1801281 were 2.0 times more likely to be in the high weight loss group than subjects with the $\mathrm{C} / \mathrm{G}-\mathrm{G} / \mathrm{G}$ genotype (table 2). For TIMP4 rs3755724, subjects with the T/C genotype were also 2.0 times more likely to be in the high weight loss group than subjects with the $\mathrm{C} / \mathrm{C}-\mathrm{T} / \mathrm{T}$ genotype (table 2 ).

\section{Mixed model analysis for weight changes}

In the 275 subjects with a weight measurement after 12 months of treatment we analyzed the weight change trajectories for the genotypes that were associated with differences in weight loss at 3 or 12 months. In table 3 the outcomes of the mixed model analysis for the mean weight change over 12 months of treatment are shown for the various genotypes. Only subjects with the $\mathrm{C} / \mathrm{G}-\mathrm{G} / \mathrm{G}$ genotype compared to the $\mathrm{C} / \mathrm{C}$ genotype of PPARG rs1801282 showed significantly more weight loss during the treatment program ( $p=0.027$ ) (figure 1 and table 3). PLIN1 rs2289487 genotype C/C vs. T/TT/C and PLIN1 rs1052700 genotype T/T vs. A/A-T/A showed both a trend towards higher weight loss ( $p=0.059$ and $p=0.077$, respectively) (table 3 ). We also paired the genotypes associated with better odds of $\geq 5 \%$ weight loss from PLIN1 rs2289487, MMP2 rs1132896, PPARG rs1801282 and TIMP4 rs3755724 and compared them to all other genotype combinations. Subjects with PPARG rs1801282 C/G-G/G and TIMP4 rs3755724 T/C showed significantly higher weight loss than subjects with all other genotype combinations ( $\mathrm{P}<0.001$ ) (figure 2). Subjects with PLIN1 rs2289487 C/C and MMP2 rs1132896 C/C showed a trend towards higher weight loss over the 12 months treatment period compared to all other genotype combinations ( $p=0.093$, data not shown). 
Table 3. Estimates of mean weight change (mean and $95 \%$ confidence interval) per genotype over 12 months of treatment $(\mathrm{N}=275)$.

\begin{tabular}{|c|c|c|c|c|c|}
\hline Gene & rs number & Genotype & $\begin{array}{l}\text { Mean weight change } \\
\text { over } 12 \text { months (\%) }\end{array}$ & Difference (\%) & P-value \\
\hline \multirow[t]{2}{*}{ PLIN1 } & Rs2289487 & $\mathrm{C} / \mathrm{C}(\mathrm{N}=39)$ & $-9.3(-11.2$ to -7.5$)$ & $-1.9(-3.9$ to 0.1$)$ & 0.059 \\
\hline & & $\mathrm{T} / \mathrm{T}-\mathrm{T} / \mathrm{C}(\mathrm{N}=234)$ & $-7.4(-8.2$ to -6.7$)$ & & \\
\hline \multirow[t]{2}{*}{ PLIN1 } & Rs2304795 & $\mathrm{G} / \mathrm{G}(\mathrm{N}=38)$ & $-6.7(-8.8$ to -5.1$)$ & $0.9(-1.1$ to 2.9$)$ & 0.378 \\
\hline & & $A / A-G / A(N=230)$ & $-7.9(-8.6$ to -7.1$)$ & & \\
\hline \multirow[t]{2}{*}{ PLIN1 } & Rs1052700 & $\mathrm{T} / \mathrm{T}(\mathrm{N}=42)$ & $-9.1(-10.9$ to -7.4$)$ & $-1.7(-3.7$ to 0.2$)$ & 0.077 \\
\hline & & $A / A-T / A(N=232)$ & $-7.4(-8.1$ to -6.6$)$ & & \\
\hline \multirow[t]{2}{*}{ MMP2 } & Rs1132896 & $\mathrm{C} / \mathrm{C}(\mathrm{N}=43)$ & $-8.2(-9.9$ to -6.4$)$ & $-0.6(-2.5$ to 1.3$)$ & 0.578 \\
\hline & & $\mathrm{G} / \mathrm{G}-\mathrm{G} / \mathrm{C}(\mathrm{N}=227)$ & $-7.6(-8.3$ to -6.8$)$ & & \\
\hline \multirow[t]{2}{*}{ PPAR gamma } & Rs1801282 & $C / C(N=211)$ & $-7.2(-8.0$ to -6.4$)$ & $1.8(0.2$ to 3.5$)$ & 0.027 \\
\hline & & $\mathrm{C} / \mathrm{G}-\mathrm{G} / \mathrm{G}(\mathrm{N}=63)$ & $-9.1(-10.5$ to -7.6$)$ & & \\
\hline \multirow[t]{2}{*}{ TIMP4 } & Rs3755724 & $\mathrm{T} / \mathrm{C}(\mathrm{N}=122)$ & $-8.2(-9.2$ to -7.1$)$ & $-0.9(-2.3$ to 0.5$)$ & 0.191 \\
\hline & & $\mathrm{C} / \mathrm{C}-\mathrm{T} / \mathrm{T}(\mathrm{N}=148)$ & $-7.2(-8.2$ to -6.3$)$ & & \\
\hline
\end{tabular}




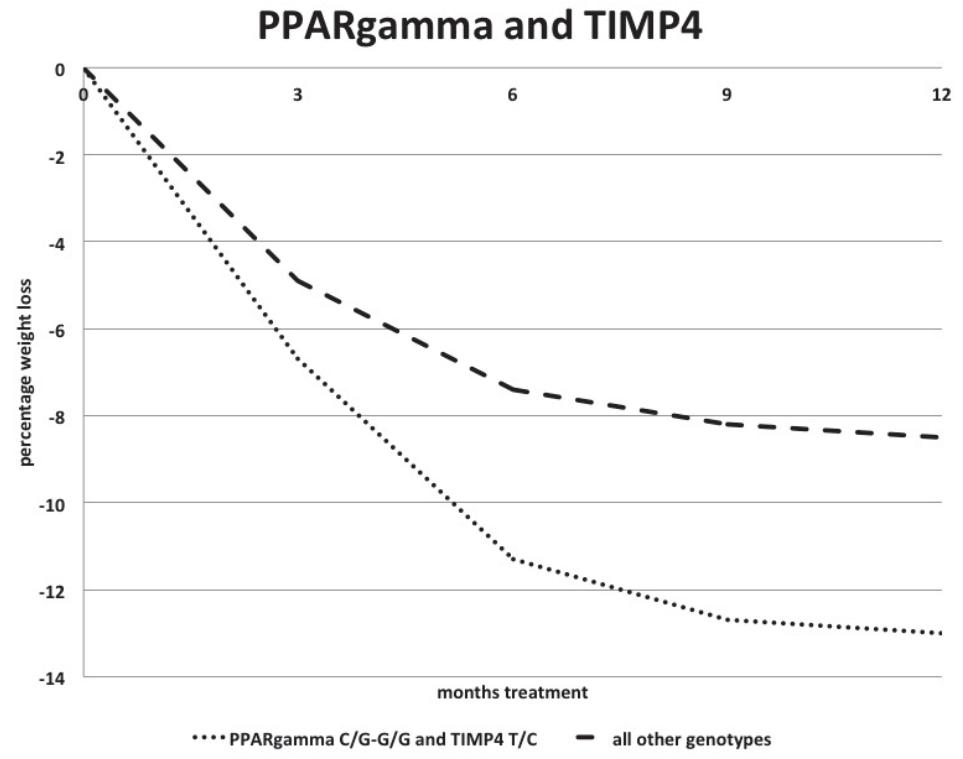

Figure 1. Weight loss during 12 months of treatment for carriers of the $C / C$ genotype vs the $C / G-G / G$ genotypes of PPARgamma rs1801282.

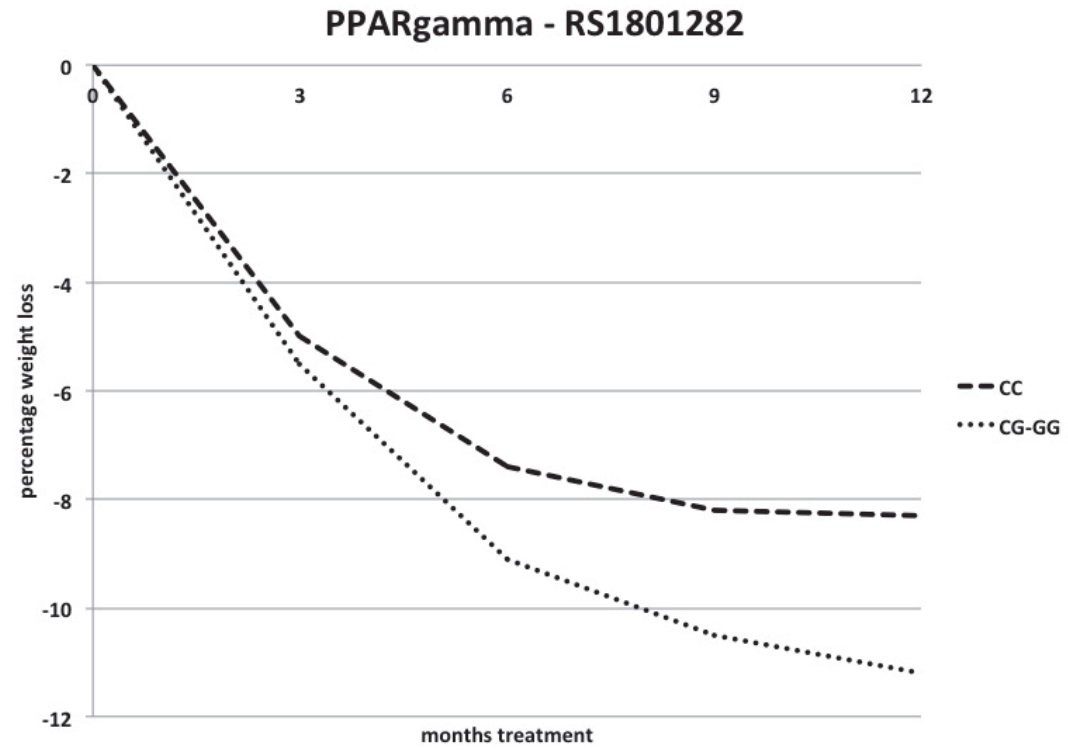

Figure 2. Weight change during the 12 months treatment for the pairs of PPARgamma rs $1801282 \mathrm{C} / \mathrm{G}-\mathrm{GG}$ and TIMP4 rs3755724 T/C, and all other genotype combinations of PPARgamma and TIMP4. 


\section{Discussion}

In this study we have investigated the genetic predisposition to a 3 and 12 month weight loss in subjects participating in a multidisciplinary obesity treatment program. Genetic factors after 3 months (PLIN1, MMP2) and 12 months (PPARG, TIMP4) were identified. The genetic variation in PPARG and TIMP4 showed a synergistic effect on weight loss. This is, to our knowledge, the first study to report genetic and weight loss data on such a large number of severely obese subjects undergoing a commercial multidisciplinary treatment program.

We acknowledge that our study has some limitations. There was a high drop-out rate of $54 \%$ over the 12 month treatment period. Drop-out rates are known to be a major problem when analyzing data from obesity treatments in a real-life setting compared to well-controlled scientific studies (23). Therefore, the high drop-out may have reduced the power of our study. In order to check if drop-out might have influenced the allele frequencies of those who were still in at 12 months, we compared the allele frequencies of the four polymorphismsm in the different genes between the total group, the group at 12 months and the drop-outs, but we found no significant difference. Instead of using multiple test correction, we looked for associations by scoring if the $95 \%$ confidence intervall was different from unity with a value of $P<0.05$. Applying multiple test-correction would shift the border for statistical significance to $\mathrm{P}=0.002$. This would give the same final conclusions, that at 3 months an association exists between weight loss and PLIN1, in particular in women $(P=0.002$, see below), and at 12 months with TIMP4 $(P<0.001)$. For the SNPs not reaching this level of statistical significance, results from previous studies can confirm their relevance.

Perilipin 1 (PLIN1) is a well-characterized effector of energy and lipid metabolism and as a lipid droplet-coating protein it controls access to the adipocyte triglyceride stores that supply most tissues with fuel under a negative energy balance (24). It has been reported to play a role in body weight regulation. In a weight loss/maintenance study of obese/overweight men and women Soenen et al. (4) found that the haplotype of PLIN1 rs2289487 (C-allele) and PLIN1 rs894160 (A-allele) was related to a lower body mass, fat mass and fat-free mass in men at baseline and throughout the intervention. This haplotype was also related to a better weight reduction after 12 months follow-up in women (4). In addition, PLIN1 rs2289487 T > C has previously been associated with a reduced risk of obesity in Spanish women (25). In the present study we found that for the total group the C/C genotype of PLIN1 rs2289487 predicted high weight loss in the first 3 months, and C/C-genotype carriers showed a trend for a higher weight loss over 12 months of treatment. Since from other studies it is clear that there is a sexdifference in the association between weight loss and PLIN1 SNPS, we decided to test for association with PLIN1 rs2289487 separately among females and males. At 3 months, the C/C genotype of this SNP of the PLIN1 gene showed significance as a predictor for high weight loss in females ( $P=0.002$; OR 1.41-4.85). At 12 months there is a 
trend for high weight loss ( $P=0.07$; OR 0.89-6.14). As such our findings are in line with the studies done by others.

The variation in the PLIN1 gene rs2289487 is in linkage disequilibrium with rs 1052700 (4). Therefore it is not surprising that these polymorphisms give almost the same results. For $\mathrm{rs} 1052700$ the $\mathrm{T} / \mathrm{T}$ genotype predicted high weight loss after 3 months and $\mathrm{T} / \mathrm{T}$ genotype carriers showed a trend for higher weight loss over 12 months of treatment. Soenen et al. (4) reported that men with the T/T genotype compared to the A/A-T/A genotype had a significantly lower weight, fat mass and fat-free mass at baseline and throughout the intervention, whereas women with the T/T genotype had a significantly lower plasma leptin level. In other studies the analysis of weight loss and obesity risk in T-allele carriers of PLIN1 rs1052700 showed a lower obesity risk in women (26) and a higher weight loss after a weight-loss intervention in children and adults $(27,28)$, although one study reported a higher obesity risk in women (29). Our results are in accordance with the data from most of these studies.

For yet another polymorphism in the PLIN1 gene, rs2304795, the G/G genotype was found to be associated with higher odds for high weight loss at 3 months, but no relation with weight loss over a period of 12 month treatment was observed, which complies with absence of linkage disequilibrium between this polymorphism and the other two tested SNPs in the PLIN1 gene. In the study by Soenen et al. (4) it was observed that the G-allele in a haplotype with the A allele of PLIN1 rs2304796 was associated with a significantly larger reduction of fat mass and fat percentage, but only in female subjects. In two studies performed by Qi et al. regarding PLIN1 gene polymorphisms, PLIN1 rs2304795 was associated with higher obesity risk in women $(26,29)$. In our study there is only a trend at 3 months for women with the G/G genotype of this SNP of the PLIN1 gene to have lower odds for high weight loss ( $p=0.07$; OR 0.11-1.16). Lower odds for high weight loss could be interpreted as a higher obesity risk, which would comply with the studies by Qi et al.

Matrix metalloproteinases (MMPs) are essential for extracellular matrix (ECM) remodeling. The remodeling of the adipocyte ECM occurs during the development and growth of the fat depot (10), but probably also when adipocytes shrink under conditions of calorie restriction (9). The results from our study indicate that MMP2 rs1132896 (C/C genotype) is a predictor for high weight loss at 3 months. In a recent study on long term weight development, the C-allele was found to be associated with risk for weight gain in women (30). In a study among Koreans, the C-allele of MMP2 rs1132896 was found to increase the risk for the development of obesity (31). It suggests that the C-allele is representing a form of MMP2 that provides higher flexibility to the adipocyte ECM both under requirements of cell shrinkage or cell growth.

Two polymorphisms had odds for better weight loss at 12 months of treatment: TIMP4 rs3755724 (T/C genotype) and PPARG (C/C genotype). Like MMPs, tissue inhibitors (TIMPS) are also active during adipose tissue remodeling (10). To the best of our knowledge this is the first report of a relation between TIMP genetic variation and 
weight loss. No association with mean weight loss over 12 months was observed (table 3). PPARG is known to have a role in adipocyte differentiation, lipid metabolism and glucose homeostasis. It also controls the expression of adiponectin, resistin, leptin and tumor necrosis factor $\alpha$ (TNF- $\alpha$ ) secreted from adipose tissue (32). For rs1801282, a C/G SNP also known concerning the protein as Pro12Ala (33) we found that at 12 months subjects with the $\mathrm{C} / \mathrm{C}$ genotype are at higher odds for high weight loss than subjects with the C/G-G/G genotype, and the G-allele carriers showed a higher loss of relative body weight over the 12 month treatment period. G-allele carriers have slightly higher baseline body weight $(+0.7 \mathrm{~kg})$ as compared to subjects with the $\mathrm{C} / \mathrm{C}$-genotype. These findings are in accordance with a meta-analysis showing that carriers of the Ala12 allele had a higher average BMI (34), and also with the study of Delahanty et al. (3), who found that 6 months and 2 years weight loss was associated with the minor Ala12 allele of the PPARG gene. Bozina et al. (35) found that carriers of the Pro12Ala (C/G) or Ala12Ala (G/G) genotype had greater odds for obesity, but this was in a specific subsample with the angiotensin converting enzyme (ACE) DD-genotype.

Interestingly, both the 3 month and 12 month analyses provide evidence on the involvement of the same processes in the genetic predisposition to weight loss by dietary and lifestyle advice, i.e. fat storage in adipocytes (PLIN1 and PPARG) and adipose tissue remodeling (MMP2, TIMP4). Variation in genes involved in other processes like the sympathetic nervous system (ADRB2, CNTF), hypothalamic regulation of eating behavior (BNDF, FTO, LEP) or peripheral energy metabolism (ACE, ADIPOQ) did not show associations. It indicates that the capacity to lose weight in the investigated cohort depends largely on the (genetically determined) performance to preserve the stored fat and on the structural flexibility of the adipocytes. Those characteristics may also be reflected in a lower baseline BMI for the high weight loss group at 3 and 12 months. In vivo, regulation of fat storage and structural adaptation of the adipocytes are expected to be linked processes. Here we found with the mixed model analysis for mean weight change over the 12 months period that subjects with the combination of the genotypes associated with higher weight loss of PPARG and TIMP4 (PPARG rs1801282 C/G-G/G and TIMP4 rs3755724 T/C) showed significantly higher weight loss than all other genotype combinations $(P<0.001)$, and a trend for combining SNPs of PLIN1 and MMP2 ( $P=0.09)$. This synergistic effect seems to confirm that both processes are interacting and determine the success of weight loss.

In conclusion, weight loss of severely obese subjects by dietary advice, psychological counseling and increased physical activity in real-life conditions depends on genetic background. Relevant genetic variation relates to genes involved in adipocyte fat storage and structural adaptation of the adipocytes during fat reduction. These findings can be of importance when searching for explanations regarding treatment success or failure. 


\section{Acknowledgements}

EA performed the analyses and wrote the manuscript. EM and MvB provided the idea for the study and improved the manuscript. FB provided technical assistance on DNA handling and genotyping.

\section{References}

1. Teixeira PJ, Going SB, Sardinha LB, Lohman TG. A review of psychosocial pre-treatment predictors of weight control. Obesity reviews : an official journal of the International Association for the Study of Obesity. 2005;6(1):43-65.

2. Stubbs J, Whybrow S, Teixeira P, Blundell J, Lawton C, Westenhoefer J, et al. Problems in identifying predictors and correlates of weight loss and maintenance: implications for weight control therapies based on behaviour change. Obesity reviews : an official journal of the International Association for the Study of Obesity. 2011;12(9):688-708.

3. Delahanty LM, Pan Q, Jablonski KA, Watson KE, McCaffery JM, Shuldiner A, et al. Genetic predictors of weight loss and weight regain after intensive lifestyle modification, metformin treatment, or standard care in the Diabetes Prevention Program. Diabetes care. 2012;35(2):363-6.

4. Soenen S, Mariman EC, Vogels N, Bouwman FG, den Hoed M, Brown L, et al. Relationship between perilipin gene polymorphisms and body weight and body composition during weight loss and weight maintenance. Physiology \& behavior. 2009;96(4-5):723-8.

5. Speliotes EK, Willer CJ, Berndt SI, Monda KL, Thorleifsson G, Jackson AU, et al. Association analyses of 249,796 individuals reveal 18 new loci associated with body mass index. Nature genetics. 2010;42(11):937-48.

6. Vogels N, Mariman EC, Bouwman FG, Kester AD, Diepvens K, Westerterp-Plantenga MS. Relation of weight maintenance and dietary restraint to peroxisome proliferator-activated receptor gamma2, glucocorticoid receptor, and ciliary neurotrophic factor polymorphisms. The American journal of clinical nutrition. 2005;82(4):740-6.

7. Erez G, Tirosh A, Rudich A, Meiner V, Schwarzfuchs D, Sharon N, et al. Phenotypic and genetic variation in leptin as determinants of weight regain. Int J Obes (Lond). 2011;35(6):785-92.

8. Mariman EC, Wang P. Adipocyte extracellular matrix composition, dynamics and role in obesity. Cellular and molecular life sciences : CMLS. 2010;67(8):1277-92

9. Mariman EC. Human biology of weight maintenance after weight loss. Journal of nutrigenetics and nutrigenomics. 2012;5(1):13-25.

10. Chavey C, Mari B, Monthouel MN, Bonnafous S, Anglard P, Van Obberghen E, et al. Matrix metalloproteinases are differentially expressed in adipose tissue during obesity and modulate adipocyte differentiation. The Journal of biological chemistry. 2003;278(14):11888-96.

11. Wheeler E, Huang N, Bochukova EG, Keogh JM, Lindsay S, Garg S, et al. Genome-wide SNP and CNV analysis identifies common and low-frequency variants associated with severe early-onset obesity. Nature genetics. 2013;45(5):513-7.

12. Zhao J, Bradfield JP, Zhang H, Sleiman PM, Kim CE, Glessner JT, et al. Role of BMI-associated loci identified in GWAS meta-analyses in the context of common childhood obesity in European Americans. Obesity. 2011;19(12):2436-9.

13. Graff M, Ngwa JS, Workalemahu T, Homuth G, Schipf S, Teumer A, et al. Genome-wide analysis of BMI in adolescents and young adults reveals additional insight into the effects of genetic loci over the life course. Human molecular genetics. 2013;22(17):3597-607.

14. Zhang H, Wu J, Yu L. Association of Gln27Glu and Arg16Gly polymorphisms in Beta2-adrenergic receptor gene with obesity susceptibility: a meta-analysis. PloS one. 2014;9(6):e100489. 
15. Mariman EC. Future nutrigenetics: in search of the missing genetic variation. Journal of nutrigenetics and nutrigenomics. 2009;2(4-5):257-62.

16. Mariman EC, Bouwman FG, Aller EE, van Baak MA, Wang P. Extreme obesity is associated with variation in genes related to the circadian rhythm of food intake and hypothalamic signaling. Physiological genomics. 2015:physiolgenomics 000062015.

17. Scherer PE, Williams S, Fogliano M, Baldini G, Lodish HF. A novel serum protein similar to C1q, produced exclusively in adipocytes. The Journal of biological chemistry. 1995;270(45):26746-9.

18. Wang P, Holst C, Wodzig WK, Andersen MR, Astrup A, van Baak MA, et al. Circulating ACE is a predictor of weight loss maintenance not only in overweight and obese women, but also in men. Int J Obes (Lond). 2012;36(12):1545-51.

19. Kim YJ, Sano T, Nabetani T, Asano Y, Hirabayashi Y. GPRC5B activates obesity-associated inflammatory signaling in adipocytes. Science signaling. 2012;5(251):ra85.

20. Sole X, Guino E, Valls J, Iniesta R, Moreno V. SNPStats: a web tool for the analysis of association studies. Bioinformatics. 2006;22(15):1928-9.

21. Franz MJ, VanWormer JJ, Crain AL, Boucher JL, Histon T, Caplan W, et al. Weight-loss outcomes: a systematic review and meta-analysis of weight-loss clinical trials with a minimum 1-year follow-up. Journal of the American Dietetic Association. 2007;107(10):1755-67.

22. Klein S, Burke LE, Bray GA, Blair S, Allison DB, Pi-Sunyer X, et al. Clinical implications of obesity with specific focus on cardiovascular disease: a statement for professionals from the American Heart Association Council on Nutrition, Physical Activity, and Metabolism: endorsed by the American College of Cardiology Foundation. Circulation. 2004;110(18):2952-67.

23. Dalle Grave R, Calugi S, Molinari E, Petroni ML, Bondi M, Compare A, et al. Weight loss expectations in obese patients and treatment attrition: an observational multicenter study. Obesity research. 2005;13(11):1961-9.

24. Smith CE, Ordovas JM. Update on perilipin polymorphisms and obesity. Nutrition reviews. 2012;70(10):611-21.

25. Qi L, Corella D, Sorli JV, Portoles O, Shen H, Coltell O, et al. Genetic variation at the perilipin (PLIN) locus is associated with obesity-related phenotypes in White women. Clinical genetics. 2004;66(4):299-310.

26. Qi L, Tai ES, Tan CE, Shen H, Chew SK, Greenberg AS, et al. Intragenic linkage disequilibrium structure of the human perilipin gene (PLIN) and haplotype association with increased obesity risk in a multiethnic Asian population. J Mol Med (Berl). 2005;83(6):448-56.

27. Deram S, Nicolau CY, Perez-Martinez P, Guazzelli I, Halpern A, Wajchenberg BL, et al. Effects of perilipin (PLIN) gene variation on metabolic syndrome risk and weight loss in obese children and adolescents. The Journal of clinical endocrinology and metabolism. 2008;93(12):4933-40.

28. Jang Y, Kim OY, Lee JH, Koh SJ, Chae JS, Kim JY, et al. Genetic variation the perilipin locus is associated with changes in serum free fatty acids and abdominal fat following mild weight loss. Int J Obes (Lond). 2006;30(11):1601-8.

29. Qi L, Shen H, Larson I, Schaefer EJ, Greenberg AS, Tregouet DA, et al. Gender-specific association of a perilipin gene haplotype with obesity risk in a white population. Obesity research. 2004;12(11):1758-65.

30. Bouwman FG, Boer JM, Imholz S, Wang P, Verschuren WM, Dolle ME, et al. Gender-specific genetic associations of polymorphisms in ACE, AKR1C2, FTO and MMP2 with weight gain over a 10-year period. Genes \& nutrition. 2014;9(6):434.

31. Han DH, Kim SK, Kang S, Choe BK, Kim KS, Chung JH. Matrix Metallopeptidase 2 Gene Polymorphism is Associated with Obesity in Korean Population. The Korean journal of physiology \& pharmacology : official journal of the Korean Physiological Society and the Korean Society of Pharmacology. 2008;12(3):125-9.

32. Ahmadian M, Suh JM, Hah N, Liddle $C$, Atkins AR, Downes $M$, et al. PPARgamma signaling and metabolism: the good, the bad and the future. Nature medicine. 2013;19(5):557-66.

33. Hsiao TJ, Lin E. The Pro12Ala polymorphism in the peroxisome proliferator-activated receptor gamma (PPARG) gene in relation to obesity and metabolic phenotypes in a Taiwanese population. Endocrine. 2014. 
34. Galbete C, Toledo E, Martinez-Gonzalez MA, Martinez JA, Guillen-Grima F, Marti A. Pro12Ala variant of the PPARG2 gene increases body mass index: An updated meta-analysis encompassing 49,092 subjects. Obesity. 2013;21(7):1486-95.

35. Bozina T, Sertic J, Lovric J, Jelakovic B, Simic I, Reiner Z. Interaction of genetic risk factors confers increased risk for metabolic syndrome: the role of peroxisome proliferator-activated receptor gamma. Genetic testing and molecular biomarkers. 2014;18(1):32-40. 
Supplementary table 1 complete list of tested SNPS

\begin{tabular}{|c|c|c|c|c|}
\hline Gene & Rs number & Alleles & Frequency & $\begin{array}{l}\text { HWE } \\
\text { p-value }\end{array}$ \\
\hline ACE & rs4340 & DEL/INS & $0.52 / 0.48$ & 0.4 \\
\hline ADIPOQ & rs17300539 & $\mathrm{G} / \mathrm{A}$ & $0.92 / 0.08$ & 0.81 \\
\hline ADIPOQ & rs266729 & $\mathrm{C} / \mathrm{G}$ & $0.75 / 0.25$ & 0.34 \\
\hline ADRB2 & rs1042713 & $\mathrm{G} / \mathrm{A}$ & $0.62 / 0.38$ & 0.44 \\
\hline BDNF & rs10767664 & $\mathrm{A} / \mathrm{T}$ & $0.8 / 0.2$ & 0.71 \\
\hline CNTF & rs1800169 & $\mathrm{G} / \mathrm{A}$ & $0.83 / 0.17$ & 0.13 \\
\hline COL4A1 & rs3742207 & $T / G$ & $0.64 / 0.36$ & 0.36 \\
\hline COL4A2 & rs9580500 & $\mathrm{T} / \mathrm{C}$ & $0.54 / 0.46$ & 1 \\
\hline COL6A1 & rs1053312 & $\mathrm{G} / \mathrm{A}$ & $0.68 / 0.32$ & 1 \\
\hline COL6A2 & rs2839110 & $A / G$ & $0.81 / 0.19$ & 0.33 \\
\hline COL6A3 & rs2270669 & $\mathrm{G} / \mathrm{C}$ & $0.77 / 0.23$ & 0.5 \\
\hline FTO & rs9939609 & $\mathrm{T} / \mathrm{A}$ & $0.61 / 0.39$ & 0.37 \\
\hline FTO & rs1558902 & $\mathrm{T} / \mathrm{A}$ & $0.6 / 0.4$ & 0.53 \\
\hline LEP & rs4731426 & $\mathrm{C} / \mathrm{G}$ & $0.57 / 0.43$ & 0.9 \\
\hline MMP2 & rs1132896 & $\mathrm{G} / \mathrm{C}$ & $0.62 / 0.38$ & 0.3 \\
\hline Near GNPDA2 & rs10938397 & $A / G$ & $0.57 / 0.43$ & 0.32 \\
\hline Near GPRC5B & rs12444979 & $\mathrm{C} / \mathrm{T}$ & $0.89 / 0.11$ & 0.55 \\
\hline Near MC4R & rs571312 & $\mathrm{C} / \mathrm{A}$ & $0.67 / 0.33$ & 0.78 \\
\hline Near PRKD1 & rs11847697 & $\mathrm{C} / \mathrm{T}$ & $0.94 / 0.06$ & 0.61 \\
\hline Near TMEM18 & rs2867125 & $\mathrm{C} / \mathrm{T}$ & $0.87 / 0.13$ & 0.44 \\
\hline PLIN1 & rs2289487 & $A / G$ & $0.6 / 0.4$ & 0.38 \\
\hline PLIN1 & rs2304795 & $A / G$ & $0.64 / 0.36$ & 0.35 \\
\hline PLIN1 & rs1052700 & $\mathrm{A} / \mathrm{T}$ & $0.6 / 0.4$ & 0.71 \\
\hline PPARG & rs1801282 & $\mathrm{C} / \mathrm{G}$ & $0.87 / 0.13$ & 0.4 \\
\hline PPARG & rs41423247 & $\mathrm{G} / \mathrm{C}$ & $0.62 / 0.38$ & 0.12 \\
\hline QPCTL & rs2287019 & $\mathrm{C} / \mathrm{T}$ & $0.81 / 0.19$ & 0.33 \\
\hline SEC16B & rs543874 & $A / G$ & $0.78 / 0.22$ & 1 \\
\hline $\mathrm{SH} 2 \mathrm{~B} 1$ & rs7359397 & $\mathrm{C} / \mathrm{T}$ & $0.61 / 0.39$ & 0.52 \\
\hline SLC39A8 & rs13107325 & $\mathrm{C} / \mathrm{T}$ & $0.94 / 0.06$ & 0.52 \\
\hline TIMP4 & rs3755724 & $\mathrm{C} / \mathrm{T}$ & $0.65 / 0.35$ & 0.89 \\
\hline
\end{tabular}




\section{CHAPTER 7}

\section{General discussion}




\section{Introduction}

Obesity is one of the major health-related problems of modern time (1). The multifactorial aspect of obesity causes the treatment to be also multi-factorial. As not all humans are alike, finding the appropriate treatment for different patient characteristics is very important. In this thesis we aimed to give insight into factors that influence body weight, like dietary and genetic factors. The main body of this thesis consists of the evaluation of (conventional) treatment strategies and how they influence obesity and obesity- related co-morbidities. One of the goals of research concerning the treatment of obesity is finding predictors for long-term weight loss. These parameters could be used in a model to predict treatment outcome before or after an early stage of the treatment. Such a prediction could aid in finding the most optimal treatment strategy for a specific patient.

In this last chapter we discuss and elaborate on the main findings of this thesis, this is done according to the 'usual' treatment strategies in conventional obesity treatment. The role of genetic factors will also be touched upon. Recommendations for further research are addressed in each part of the discussion and at the end we present a conclusion.

\section{Physical activity}

Our study regarding the influence of physical activity on glucose tolerance revealed that in severely obese patients, an increase in physical activity can lead to significant improvements in glucose tolerance, independent of changes in body weight. Our study is the first to show such an effect in severely obese subjects. The beneficial effects of physical activity on cardiometabolic risk factors are well established. Exercise lowers blood pressure (2) and blood lipids (3) and increases insulin sensitivity (4). But such results are often produced under well controlled circumstances and the achieved (short-term) results, are often not well maintained when support is withdrawn after the intervention period $(5,6)$. It is therefore important, that people at risk find the motivation to perform regular leisure time physical activity on their own.

How much physical activity is needed to produce health benefits? A large scale study showed that leisure time physical activity of 3 to 5 times the minimum recommended amount (the minimum recommended amount being 150 minutes of moderate intensity or 75 minutes of vigorous intensity aerobic activity weekly) is associated with a near maximum longevity benefit (7). This study also underlines that already a modest amount of activity, the minimum recommended amount, provides substantial benefit with respect to postponing mortality in the general population (7). For the severely obese however, finding the strength and motivation to initiate leisure time physical activity and exercise can be quite a burden. Physical complaints when exercising (knee 
pain, back pain etc) can mean a setback and a demotivation. Within our study of participants in the CO-EUR treatment programme (chapter 5), already a modest increase of $30 \mathrm{~min} /$ day of moderate physical activity was associated with a significant improvement in glucose tolerance. This was the recommended amount of physical activity within the CO-EUR treatment programme eg. 1 group session at the treatment centre and participants were encouraged to implement two additional exercise sessions in their weekly routine. Exercise sessions should last approximately 60 minutes. This amounts to 180 minutes per week or $25 \mathrm{~min} /$ day. With respect to the amount of physical activity that has to be performed to prevent the transition from overweight to obesity, the International Association for the Study of Obesity recommends at least 45-60 min/day of moderate activity, and to prevent weight regain 60-90 min/day of moderate activity is required in formerly obese individuals (8). So for weight maintenance it is recommendable to strive for $60 \mathrm{~min} /$ day rather than the $30 \mathrm{~min} /$ day recommended in the COEUR treatment programme. Getting obese people motivated to become more active should be a cornerstone of every treatment programme. This can be done by starting slowly and working on the motivation to become more active. Making active choices, parking the car a bit further away, taking the stairs instead of the elevator, already makes a good start and allows habituation to being more active and/or the formation of active habits (9).

From the above we can conclude that physical activity within a multidisciplinary obesity treatment programme, improves cardiometabolic health and can aid in weight loss maintenance. Adherence to the physical activity part in a multidisciplinary treatment programme, might be one of the predictors of long-term weight loss maintenance and could therefore be a part of a prediction model. When adherence during treatment is high, this could mean that the implementation of regular physical activity has succeeded and that the patient is likely to continue this behaviour after active treatment. As adherence data is available from the CO-EUR database, this could be a focus of future research.

\section{Diet}

The habitual diet is a powerful player in the treatment of obesity and its health related co-morbidities. Weight gain occurs when there is more energy intake, than energy expenditure. The easiest way to regulate this is to consume fewer calories. Diets that reduce energy intake can be a good way to promote weight loss, but the results are mostly short-term, and the majority of lost weight is often regained within a year (10). In our review on starches, sugars and obesity in chapter $\mathbf{2}$, we concluded that resistant starch and slowly digestible starch are attractive dietary targets for weight gain prevention and weight loss diets. The much promoted 'light' drinks containing artificial sweeteners instead of natural sweeteners may lead to caloric compensation that might even 
reverse the original benefit of the 'light' drink, but the evidence on this matter is inconclusive (11). Increasing the protein content of the diet can also help in weight loss maintenance (12-15). Our analysis of the 12 month weight loss maintenance results from two centres in the Diogenes trial (chapter 3 ), revealed that a modest increase in dietary protein content ( $7 \%$ of total energy intake) in the context of an ad libitum, diet during 12 month after diet-induced weight loss reduced weight regain by $2 \mathrm{~kg}$ compared to the lower protein groups. Also, the higher protein groups regained less fat mass than the lower protein groups.

But despite all research on this subject and the efforts of obese people, weight loss maintenance is still very difficult. The adherence to diets in the long term is minimal. Even in the absence of metabolic requirements people seem compelled to eat Animal models have been developed that capture addiction-like aspects of palatable high fat/high sugar food consumption that can lead to weight gain. This consumption is based largely on palatability rather than nutrient requirements, and is driven by the availability of such foods (16-18). In our obesogenic environment, such foods are largely available. There is mounting evidence that overeating and obesity involves addictive processes. Brain similarities to known addictions (19) show relationships with food and this satisfies DSM/WHO addiction criteria $(20,21)$. Food craving for example has been linked to body mass index and the consumption of these foods (22). Food cravings may also differentiate between successful and unsuccessful dieters (23). Even after bariatric surgery, patients report the struggle of adhering to their new diet (24). Recently, Hebebrand and colleagues suggested using the term 'eating addiction' rather than 'food addiction', in people that show overeating behaviour. The palatability of food does play role in the likeliness for people to overeat when they show eating addiction behaviour, but there is no consistent evidence that there is addictive behaviour for specific foods (25).

Next to the psychological struggle that people experience to maintain weight after weight loss, Mariman (26) has proposed a network of functional processes that might contribute to the explanation of the difficulty of weight maintenance after weight loss. This network focuses on four aspects: energy expenditure by fat-free mass, energy regulation by metabolic hormones, and physiologic and cellular resistance to weight loss (26).

Therefore, the limited success of long-term weight loss maintenance may be due to a combination between the body's resistance against weight loss and the psychological struggle of changing long-term habits. The composition of the diet can help, but is not an all-solving remedy.

As the diet has such a big influence on weight it would be a powerful parameter within a prediction model for long term weight loss maintenance. At CO-EUR a healthy diet is promoted with increased protein and reduced fat intake, and dietary intake data has been recorded. Since lowering fat intake and increasing protein intake can have a 
positive influence on weight loss and its maintenance, the changes in protein and fat intake could be useful parameters within a prediction model.

\section{Behavioural modification}

Cognitive behavioural treatment (CBT) is a potent psychological treatment for eating disorders (27). For years it has been a proven treatment for anorexia nervosa and bulimia nervosa and in recent years, research has shown that it is also effective in treating binge eating disorders (BED) (28). Obesity is often associated with a binge eating disor$\operatorname{der}(29)$ and therefore a treatment based on CBT could reduce eating binges. But CBT alone will not produce weight loss. It is advised that CBT should always be combined with physical activity and an energy restricted diet if significant weight loss is a goal of the treatment (28). In chapter 4 we reported the results of the CO-EUR treatment programme, and we showed significant improvements in eating behaviour and quality of life, accompanied by an average weight loss of approximately $10 \%$. The psychological part of the CO-EUR treatment programme is mainly based on CBT. Our data is in line with the literature that a behavioural modification programme (based on CBT) is a potent strategy to produce significant weight loss and maintenance in combination with improvements in cardiometabolic risk factors and also improves psychological wellbeing $(28,30)$.

In the previous two parts of the discussion we addressed diet and physical activity as single components of obesity treatment. They both have their positive effects as a single treatment, but research has shown that a combination of diet and physical activity in a behavioural modification programme is the best option for conservative treatment (30). This combination produces the best results with respect to weight loss compared to single treatment procedures.

Behavioural modification is needed to change the patients mindset towards their eating and physical activity habits. An often heard quote from patients is "I can't do it if I have to watch what I eat the rest of my life". Changing a mindset towards better eating behaviour does not mean living on a diet the remaining part of a lifetime. Making healthy choices and eating healthy has nothing to do with dieting. Adherence to healthy eating habits and a physically active lifestyle is less hard when the correct method to learn these behaviours is applied. When there are no psychological problems laying at the basis of the (severely) overweight, such a behavioural modification programme is a good choice.

Obesity, and especially morbid obesity, however, is often accompanied by psychological disturbances such as depression, anxiety, poor impulse control, low self-esteem and impaired quality of life $(31,32)$. Concerning family relationships, morbidly obese patients more frequently have a history of parental loss, parental alcoholism, marital family dysfunction in their own lives and dis-satisfying sexual relationships (33). To 
focus only on physical activity and diet, or even perform surgery without addressing the psychological aspects of the obese state would be a clear mistake. A history of psychological problems, should at least be taken when admitting someone to a treatment programme. Often obese people are not aware of having an eating disorder, or any other psychological problem that could form the basis of their current health status or excess weight. Specific questionnaires could provide information on this subject at an intake procedure, so that the treatment could be more specific to a persons needs or the patient can be referred to a psychologist. When people are aware of the cause of their psychological discomfort and the relation it has to their weight, they will have better chances of weight maintenance and have a lower risk of weight regain. Elfhag and Rössner reported that weight maintenance was associated with internal motivation for weight reduction, social support, better coping strategies, ability to handle life stress, self-efficacy, autonomy, and overall more psychological strength and stability (34). Aspects increasing the risk of regaining weight include binge eating, eating in response to negative emotions, stress and more passive reactions to problems (32).

From the above we can conclude that improvements in behaviour, i.e. better coping strategies, ability to handle life stress, self-efficacy, autonomy, and overall greater psychological strength and stability are parameters that are important for weight maintenance. These parameters are all measurable through existing questionnaires, with some of them already available within the CO-EUR database. These data can be a valuable addition for a prediction model for long-term weight loss maintenance.

\section{Genes}

Genetic predisposition to weight gain has been thoroughly studied in the last decade (35). Scientists search for a genetic model that could explain the rise of the obesity epidemic. There are many obesity-susceptibility loci identified through genome wide association studies like FTO, MC4R and BDNF. But all these loci together only explain a few percentages of the variation in $\mathrm{BMI}$ in the general population $(36,37)$. In parallel but less extensively, scientists have been searching for predictors of weight loss (maintenance) (38). In chapter 6 we studied genetic predisposition to high or low weight loss (maintenance). We found genetic factors associated with weight loss in subjects participating in the CO-EUR treatment programme. Applying genetic profiling as a basis for patient specific treatment design is still in its infancy. The complexity of the human body makes it very hard to predict what will happen under specific circumstances. Genetic predisposition is only one of the factors and likely not the most important one in the treatment of a multifactorial disease like obesity. Nevertheless, knowledge of the influence of genetic predisposition on treatment success may help to refine predictive models of treatment outcomes. 


\section{The value of predictive models}

The development of a predictive model for long-term weight loss maintenance could be the focus of future research. The knowledge of which parameters predict weight loss response or non-response among patients can be very useful in a clinical setting. Previous studies have shown that age, sex, baseline weight, energy intake, physical activity and early weight loss are predictors of long-term weight loss (39-42). As indicated above, other factors may be included to refine prediction. Since all studies from which these predictors are derived used specific inclusion and exclusion criteria and different treatment regimes, it is not likely that these data are directly transferable to other populations and treatments. Therefore, prediction models may have to be derived for each specific population and treatment. Within the CO-EUR database there are a lot of parameters available that could be useful when constructing a predictive model specific for the CO-EUR population. A suggestion for such parameters relevant to this thesis, has already been mentioned above. When such a predictive model is developed within a clinical setting, and certain parameters predict who will be a responder or nonresponder, this can aid in the treatment. Early non-responder recognition can be a trigger to intensify the treatment or to change the treatment strategy.

\section{Conclusion}

In clinical obesity treatment a thorough intake procedure and profiling of the patient and their specific needs, rather than a 'one size fits all' approach, can help in choosing the right kind of treatment. This will aid in producing significant weight loss, and then maintaining it successfully over a long period of time. Developing a specific predictive model for the treatment setting can be useful for this purpose.

\section{References}

1. Low S, Chin MC, Deurenberg Yap M. Review on epidemic of obesity. Ann Acad Med Singapore. 2009;38(1):57-9.

2. Pescatello LS, Franklin BA, Fagard R, Farquhar WB, Kelley GA, Ray CA, et al. American College of Sports Medicine position stand. Exercise and hypertension. Medicine and science in sports and exercise. 2004;36(3):533-53.

3. Kelley GA, Kelley KS, Tran ZV. Walking, lipids, and lipoproteins: a meta-analysis of randomized controlled trials. Preventive medicine. 2004;38(5):651-61.

4. Boule NG, Haddad E, Kenny GP, Wells GA, Sigal RJ. Effects of exercise on glycemic control and body mass in type 2 diabetes mellitus: a meta-analysis of controlled clinical trials. Jama. 2001;286(10):1218-27.

5. Fjeldsoe B, Neuhaus M, Winkler E, Eakin E. Systematic review of maintenance of behavior change following physical activity and dietary interventions. Health psychology : official journal of the Division of Health Psychology, American Psychological Association. 2011;30(1):99-109. 
6. Greaves CJ, Sheppard KE, Abraham C, Hardeman W, Roden M, Evans PH, et al. Systematic review of reviews of intervention components associated with increased effectiveness in dietary and physical activity interventions. BMC public health. 2011;11:119.

7. Arem H, Moore SC, Patel A, Hartge P, Berrington de Gonzalez A, Visvanathan K, et al. Leisure Time Physical Activity and Mortality: A Detailed Pooled Analysis of the Dose-Response Relationship. JAMA internal medicine. 2015.

8. Saris WH, Blair SN, van Baak MA, Eaton SB, Davies PS, Di Pietro L, et al. How much physical activity is enough to prevent unhealthy weight gain? Outcome of the IASO 1st Stock Conference and consensus statement. Obes Rev. 2003;4(2):101-14.

9. Sallis R, Franklin B, Joy L, Ross R, Sabgir D, Stone J. Strategies for promoting physical activity in clinical practice. Progress in cardiovascular diseases. 2015;57(4):375-86.

10. Dombrowski SU, Knittle K, Avenell A, Araujo-Soares V, Sniehotta FF. Long term maintenance of weight loss with non-surgical interventions in obese adults: systematic review and meta-analyses of randomised controlled trials. Bmj. 2014;348:g2646.

11. Gardner C. Non-nutritive sweeteners: evidence for benefit vs. risk. Current opinion in lipidology. 2014;25(1):80-4.

12. Astrup A, Raben A, Geiker N. The role of higher protein diets in weight control and obesity-related comorbidities. International journal of obesity. 2014.

13. Leidy HJ, Clifton PM, Astrup A, Wycherley TP, Westerterp-Plantenga MS, Luscombe-Marsh ND, et al. The role of protein in weight loss and maintenance. The American journal of clinical nutrition. 2015.

14. Santesso N, AkI EA, Bianchi M, Mente A, Mustafa R, Heels-Ansdell D, et al. Effects of higher- versus lowerprotein diets on health outcomes: a systematic review and meta-analysis. European journal of clinical nutrition. 2012;66(7):780-8.

15. Wycherley TP, Moran L, Clifton PM, Noakes M, Brinkworth GD. Effects of energy-restricted high-protein, low-fat compared with standard-protein, low-fat diets: a meta-analysis of randomized controlled trials. The American journal of clinical nutrition. 2012;96(6):1281-98.

16. Lutter M, Nestler EJ. Homeostatic and hedonic signals interact in the regulation of food intake. The Journal of nutrition. 2009;139(3):629-32.

17. Meye FJ, Adan RA. Feelings about food: the ventral tegmental area in food reward and emotional eating. Trends in pharmacological sciences. 2014;35(1):31-40.

18. Saper CB, Chou TC, Elmquist JK. The need to feed: homeostatic and hedonic control of eating. Neuron. 2002;36(2):199-211.

19. Gearhardt AN, Yokum S, Orr PT, Stice E, Corbin WR, Brownell KD. Neural correlates of food addiction. Archives of general psychiatry. 2011;68(8):808-16.

20. Gearhardt AN, Corbin WR, Brownell KD. Preliminary validation of the Yale Food Addiction Scale. Appetite. 2009;52(2):430-6.

21. Pretlow RA. Addiction to highly pleasurable food as a cause of the childhood obesity epidemic: a qualitative Internet study. Eating disorders. 2011;19(4):295-307.

22. Chao A, Grilo CM, White MA, Sinha R. Food cravings, food intake, and weight status in a communitybased sample. Eating behaviors. 2014;15(3):478-82.

23. Meule A, Lutz A, Vogele C, Kubler A. Food cravings discriminate differentially between successful and unsuccessful dieters and non-dieters. Validation of the Food Cravings Questionnaires in German. Appetite. 2012;58(1):88-97.

24. Geraci AA, Brunt A, Marihart C. The Work behind Weight-Loss Surgery: A Qualitative Analysis of Food Intake after the First Two Years Post-Op. ISRN obesity. 2014;2014:427062.

25. Hebebrand J, Albayrak O, Adan R, Antel J, Dieguez C, de Jong J, et al. "Eating addiction", rather than "food addiction", better captures addictive-like eating behavior. Neuroscience and biobehavioral reviews. 2014;47:295-306.

26. Mariman EC. Human biology of weight maintenance after weight loss. Journal of nutrigenetics and nutrigenomics. 2012;5(1):13-25. 
27. Hay P. A systematic review of evidence for psychological treatments in eating disorders: 2005-2012. The International journal of eating disorders. 2013;46(5):462-9.

28. Vanderlinden J, Adriaens A, Vlasselaer Van E, Hauman T, Vancampfort D, Pieters G. De psychotherapeutische behandeling van patiënten met de eetbuistoornis: een literatuuroverzicht. Directieve Therapie. 2010;30(3):203-21.

29. Dingemans $A E$, Bruna MJ, van Furth EF. Binge eating disorder: a review. International journal of obesity and related metabolic disorders : journal of the International Association for the Study of Obesity. 2002;26(3):299-307.

30. Johns DJ, Hartmann-Boyce J, Jebb SA, Aveyard P. Diet or exercise interventions vs combined behavioral weight management programs: a systematic review and meta-analysis of direct comparisons. Journal of the Academy of Nutrition and Dietetics. 2014;114(10):1557-68.

31. van Gemert WG, Severeijns RM, Greve JW, Groenman N, Soeters PB. Psychological functioning of morbidly obese patients after surgical treatment. International journal of obesity and related metabolic disorders : journal of the International Association for the Study of Obesity. 1998;22(5):393-8.

32. van Hout GC, van Oudheusden I, van Heck GL. Psychological profile of the morbidly obese. Obesity surgery. 2004;14(5):579-88.

33. Felitti VJ. Childhood sexual abuse, depression, and family dysfunction in adult obese patients: a case control study. Southern medical journal. 1993;86(7):732-6.

34. Elfhag K, Rossner S. Who succeeds in maintaining weight loss? A conceptual review of factors associated with weight loss maintenance and weight regain. Obesity reviews : an official journal of the International Association for the Study of Obesity. 2005;6(1):67-85.

35. Teixeira PJ, Going SB, Sardinha LB, Lohman TG. A review of psychosocial pre-treatment predictors of weight control. Obesity reviews : an official journal of the International Association for the Study of Obesity. 2005;6(1):43-65.

36. Apalasamy YD, Mohamed Z. Obesity and genomics: role of technology in unraveling the complex genetic architecture of obesity. Human genetics. 2015;134(4):361-74.

37. Loos RJ. Genetic determinants of common obesity and their value in prediction. Best practice \& research Clinical endocrinology \& metabolism. 2012;26(2):211-26.

38. Delahanty LM, Pan Q, Jablonski KA, Watson KE, McCaffery JM, Shuldiner A, et al. Genetic predictors of weight loss and weight regain after intensive lifestyle modification, metformin treatment, or standard care in the Diabetes Prevention Program. Diabetes care. 2012;35(2):363-6.

39. Thomas DM, Ivanescu AE, Martin CK, Heymsfield SB, Marshall K, Bodrato VE, et al. Predicting successful long-term weight loss from short-term weight-loss outcomes: new insights from a dynamic energy balance model (the POUNDS Lost study). The American journal of clinical nutrition. 2015;101(3):449-54.

40. Unick JL, Hogan PE, Neiberg RH, Cheskin L, Dutton GR, Evans-Hudnall G, et al. Evaluation of early weight loss thresholds for identifying nonresponders to an intensive lifestyle intervention. Obesity. 2014;22(7):1608-16.

41. Handjieva-Darlenska T, Handjiev S, Larsen TM, van Baak MA, Lindroos A, Papadaki A, et al. Predictors of weight loss maintenance and attrition during a 6-month dietary intervention period: results from the DiOGenes study. Clinical obesity. 2011;1(2-3):62-8.

42. van Baak MA, van Mil E, Astrup AV, Finer N, Van Gaal LF, Hilsted J, et al. Leisure-time activity is an important determinant of long-term weight maintenance after weight loss in the Sibutramine Trial on Obesity Reduction and Maintenance (STORM trial). The American journal of clinical nutrition. 2003;78(2):209-14 

Summary 


\section{Summary}

Since the 1980's the number of people suffering from obesity has increased dramatically. The large amount of fat accumulation in obesity presents a serious risk for health. Obesity is associated with numerous diseases like type 2 diabetes, cardiovascular disease and cancer. As obesity is a multifactorial disease, it calls for a multifactorial treatment. Treatment should cover physical activity, diet and behavioural modification with specific psychological treatment when needed. The aim of this thesis was to evaluate conservative treatment strategies within a practice based setting and to search for genetic predictors of weight loss (maintenance).

Reviewing the available recent literature until 2010 about the effects of different carbohydrates on body weight and health in chapter $\mathbf{2}$, we found that starchy foods, especially slowly digestible and resistant starches show potential beneficial effects in comparison to the potential detrimental effects of high intakes of fructose. Such starchy foods can aid in (the maintenance of) weight loss and this would make them a good addition to a healthy diet. The intake of whole grains, legumes and vegetables, which contain more appropriate sources of carbohydrates associated with reduced risk of cardiovascular and other chronic diseases, is recommended over the intake of foods rich in sugars, especially in the form of sugar-sweetened beverages.

The DIOGENES randomized clinical trial investigated the effect of dietary protein content $(P)$ and glycemic index (GI) on weight loss maintenance in overweight or obese adults in 8 centers across Europe. The original DIOGENES intervention lasted for 6 months, but the study in chapter 3 reports the 1-year results in 2 of the centers that extended the DIOGENES intervention to 1 year. 256 subjects that lost at least $8 \%$ body weight during the initial 8-week low calorie diet, were randomized to 5 ad libitum diets for 12 months high P/low GI (HP/LGI), high P/high GI (HP/HGI), low P/low GI (LP/LGI), low $P /$ high GI (LP/HGI) and a healthy control diet. During the first 6 months foods were provided for free through a shop system, during the whole 12-month period subjects received guidance by a dietician. Average weight regain over the 12-month intervention period was $3.9 \mathrm{~kg}$ but subjects on the HP diets regained less weight than subjects on the LP diets. We found no consistent effect of GI on weight regain. From this study we can conclude that an ad libitum high protein diet ( $23 \%$ of total energy intake) improves weight loss maintenance during a 12 month intervention. The use of increased dietary protein intake for weight loss (maintenance) is supported by this study.

Although there is a lot of data on the results of various obesity treatment strategies from clinical trials, practice-based data from commercial treatment centres is scarce. In chapter 4 we report the results of the CO-EUR commercial treatment centre in the Netherlands. CO-EUR provides a multidisciplinary approach for people suffering from 
obesity. This 18 months programme includes a physical activity programme, psychological counselling based on cognitive behavioural therapy (CBT) and nutritional advice to promote a healthy lifestyle. We followed 426 subjects during their treatment and used their data from anthropometric measurements and questionnaires to evaluate the programme. Our findings reveal that this 18 months treatment programme results in significant weight loss and improvements in cardiometabolic risk factors, quality of life and eating behaviour.

Impaired glucose tolerance is an often seen metabolic co-morbidity in the obese. In chapter $\mathbf{5}$ we explored the independent contributions of weight loss and physical activity to the improvement in glucose tolerance in severely obese subjects that participated in the CO-EUR treatment programme. We used accelerometers to register the amount of physical performed during as part of the treatment programme and in leisure time. Although it is well established that physical activity has beneficial health effects regarding glucose metabolism and lipid profile, our study was the first to show that increasing moderate intensity physical activity by 30 min day-1 significantly improved glucose tolerance independent of weight loss in severely obese subjects. These results underline the importance of physical activity within a multidisciplinary obesity treatment programme.

It is well established that environmental factors like dietary habits are important contributors to weight maintenance. Genetic factors, however, likely also play a role. To gain more knowledge about the role of genetics in weight loss (maintenance) we performed the study described in chapter 6 . For this study we collected DNA samples and used the 3 monthly weight measurement from 587 obese subjects enrolled in the COEUR treatment programme. The association between genotypes, grouped according to the best inheritance model, and weight loss was assessed after 3 months of treatment (short-term) and after 12 months of treatment (long-term). For these analyses weight loss was categorized as $\geq 5 \%$ of initial weight or $<5 \%$ of initial weight. Our results show that polymorphisms in genes related to regulation of fat storage (PLIN1 and PPARG) and structural adaptation of the adipocytes (MMP2 and TIMP4) are predictors for weight loss with different genes being relevant for short term and the long term weight loss. Combined genotype analysis shows interaction between the fat storage and adipocyte structural adaptation processes during weight loss.

This thesis concludes that diet, physical activity and behavioural treatment all have their strengths in the multifactorial aspect of obesity treatment. It is recommended that these treatment strategies should be combined rather than being implemented as single treatments. Treatment outcome is likely to be influenced by genetic factors, but more research is needed on this topic. Prediction models for treatment outcome, con- 
sisting of many determinants like environmental and genetic factors, could play an important role in the future. At this time however, such models are still in their infancy. 
Samenvatting 


\section{Samenvatting}

Sinds de tachtiger jaren is het aantal mensen met obesitas drastisch gestegen. De grote toename van vetweefsel bij obesitas leidt tot ernstige gezondheidsrisico's. Obesitas wordt geassocieerd met tal van ziektes zoals type 2 diabetes, hart -en vaatziekten en kanker. De multifactoriële aard van obesitas maakt ook een multifactoriële behandeling noodzakelijk. Een behandeling zou moeten bestaan uit voeding, beweging en gedragsverandering met, indien nodig, een specifieke psychologische behandeling. Het doel van dit proefschrift was het evalueren van conservatieve behandelstrategieën binnen een praktijkgerichte situatie en het zoeken naar genetische voorspellers van (blijvend) gewichtsverlies.

In een overzicht van de beschikbare literatuur tot 2010 over de gewichts- en gezondheidseffecten van verschillende soorten koolhydraten in hoofdstuk $\mathbf{2}$, vonden we dat zetmeelrijke voedingsmiddelen en met name langzame en onverteerbare zetmelen, potentiële gunstige effecten hebben in vergelijking met de mogelijke ongunstige effecten van hoge fructose-inname. Zulke zetmeelrijke voedingsmiddelen kunnen helpen bij (het behouden van) gewichtsverlies en kunnen daarom een goede toevoeging zijn aan een gezond voedingspatroon. De inname van volkoren producten, peulvruchten en groenten, die de meer geschikte bronnen van koolhydraten bevatten die samenhangen met een verlaagd risico op hart -en vaatziekten en andere chronische ziekten, wordt aanbevolen in plaats van de inname van voedingsmiddelen die rijk zijn aan suikers en dan met name in de vorm van met suiker gezoete (fris)drank.

Het DIOGENES gerandomiseerde klinische onderzoek onderzocht het effect van de hoeveelheid eiwit (P) in de voeding en de glycemische index (GI) op het behoud van gewichtsverlies in volwassenen met overgewicht of obesitas in 8 centra verspreid over Europa. De oorspronkelijke DIOGENES interventie duurde 6 maanden, maar de studie in hoofdstuk 3 beschrijft de resultaten na 1 jaar van 2 van de centra die de DIOGENES interventie verlengden tot 1 jaar. 256 proefpersonen die ten minste $8 \%$ lichaamsgewicht hadden verloren tijdens het initiële 8 weken durende laag-calorisch dieet, werden voor de duur van 12 maanden gerandomiseerd ingedeeld in 5 ad libitum voedingsgroepen: hoog P/laag GI (HP/LGI), hoog P/hoog GI (HP/HGI), laag P/laag GI (LP/LGI), laag

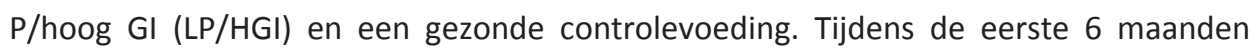
werden de voedingsmiddelen gratis verstrekt via een winkel-systeem en gedurende de hele 12 maanden was er begeleiding door een diëtist. Gemiddeld kwamen de proefpersonen weer $3,9 \mathrm{~kg}$ bij in gewicht tijdens de 12 maanden interventie, maar de proefpersonen met een HP voeding kwamen minder bij in gewicht dan de proefpersonen met een LP voeding. We vonden geen stelselmatig effect van GI op het weer bijkomen in gewicht. Aan de hand van deze studie kunnen we concluderen dat een ad libitum eiwitrijke voeding ( 23\% van de energie-inname) het behoud van gewichtsverlies verbe- 
tert gedurende een 12 maanden interventie. Het verhogen van de hoeveelheid eiwit in de voeding voor het gebruik bij (behoud van) gewichtsverlies wordt met deze studie ondersteund.

Er is veel data beschikbaar over obesitasbehandelstrategieën uit klinische studies, maar praktijkgerichte gegevens van commerciële behandelcentra zijn zeldzaam. In hoofdstuk 4 beschrijven we de resultaten van het CO-EUR commerciële behandelcentrum in $\mathrm{Ne}-$ derland. CO-EUR biedt een multidisciplinaire aanpak voor mensen met obesitas. Dit 18 maanden durende programma bestaat uit het verhogen van de lichamelijke activiteit, psychologische behandeling op basis van cognitieve gedragstherapie (CGT) en voedingsadvies voor het bevorderen van een gezonde leefstijl. We volgden 426 personen tijdens hun behandeling en we gebruikte hun gegevens van lichaamsmetingen en vragenlijsten om het behandelprogramma te evalueren. Onze bevindingen laten zien dat dit 18 maanden behandelprogramma resulteert in significant gewichtsverlies en verbetering van cardiometabole risicofactoren, kwaliteit van leven en eetgedrag.

Gestoorde glucosetolerantie is een vaak geziene metabole co-morbiditeit bij obesitas. In hoofdstuk $\mathbf{5}$ onderzochten we de onafhankelijke bijdrage van gewichtsverlies en lichamelijke activiteit op de verbetering van glucosetolerantie in ernstig obese proefpersonen die deelnamen aan het CO-EUR behandelprogramma. We maakten gebruik van versnellingsmeters om de hoeveelheid lichamelijke activiteit als deel van de behandeling en in de vrije tijd te registreren. Het is bekend dat lichamelijke activiteit een gunstig effect op het glucosemetabolisme en het vetgehalte in het bloed heeft, maar onze studie was de eerste die aantoonde dat een toename van matig intensieve lichamelijke activiteit van 30 minuten per dag de glucosetolerantie significant verbetert in ernstig obese proefpersonen, onafhankelijk van gewichtsverlies. Deze resultaten benadrukken hoe belangrijk lichamelijk activiteit binnen een multidisciplinair obesitas behandelprogramma is.

Het is bekend dat omgevingsfactoren zoals voedingsgewoonten een belangrijke invloed hebben op behoud van lichaamsgewicht. Echter genetische factoren dragen hier waarschijnlijk ook aan bij. Om meer kennis te vergaren over de rol van (behoud van) gewichtsverlies hebben we het onderzoek zoals beschreven in hoofdstuk 6 uitgevoerd. Voor dit onderzoek hebben we DNA monsters en de 3 maandelijkse gewichtsmetingen gebruikt van 587 obese personen die deelnamen aan het CO-EUR behandelprogramma. De overeenkomsten tussen genotypen, gegroepeerd volgens het beste erfelijke model, en gewichtsverlies werden bekeken na 3 maanden behandeling (korte termijn) en na 12 maanden behandeling (lange termijn). Voor deze analyse hebben we het gewichtsverlies in categorieën ingedeeld: $\geq 5 \%$ initieel gewichtsverlies of $<5 \%$ initieel gewichtsverlies. Onze resultaten laten zien dat polymorfismen in genen die gerelateerd zijn aan de regulatie van vetopslag (PLIN1 en PPARG) en de structurele aanpassing van de vetcellen 
(MMP2 en TIMP4) voorspellers zijn van gewichtsverlies, waarbij de genen die relevant zijn voor gewichtsverlies op lange- en korte termijn verschillen. Gecombineerde genotype-analyse laat een interactie zien tussen de vetopslag en de aanpassingsprocessen in de structuur van de vetcel tijdens gewichtsverlies.

In dit proefschrift concluderen wij dat dieet, lichamelijke activiteit en gedragstherapie allemaal hun sterke punten hebben binnen het multifactoriële aspect van de obesitasbehandeling. Aanbevolen wordt deze behandelstrategieën gecombineerd in te zetten in plaats van toegepast als alleenstaande behandelingen. Het behandelresultaat wordt ook beïnvloed door genetische factoren, maar er is meer onderzoek nodig op dit gebied. Modellen die het behandelresultaat voorspellen, die bestaan uit veel determinanten zoals omgevings- en genetische factoren, kunnen een belangrijke rol gaan spelen in de toekomst. Echter op dit moment staan zulke modellen nog in hun kinderschoenen. 
Valorization 


\section{Valorization}

\section{Social relevance}

The dramatic worldwide rise of overweight and obesity since the 1980's is alarming. Prevalence has increased from $28.8 \%$ to $36.9 \%$ in men, and from $29.8 \%$ to $38.0 \%$ in women. Nowadays, even $23 \%$ percent of children are overweight or obese. Although the increase in developed countries has slowed down since 2006, the developing countries still show a dramatic rise. In some developing countries the estimated obesity rate exceeds $50 \%$. Weight gain is the result of a structural imbalance between energy intake and energy expenditure. In our 'obesogenic' environment with an abundance of highly palatable foods, the temptation of eating more calories than needed is very high. Disturbed eating behaviour is a common condition among obese patients, and the abundance of calorie dense high palatable foods makes this problem even worse. Next to the association with psychological problems, overweight and obesity also increase the risk of numerous co-morbid conditions like type 2 diabetes mellitus, cardiovascular disease and cancer that not only present a serious risk for health, but also increase the economic burden of obesity. Treating these co-morbid conditions increases health care costs and when people cannot work because of their illness, the economic burden only gets worse. Not to mention the estimated 3.4 million deaths caused by overweight and obesity each year.

It is clear that there is a need to combat this epidemic and that every possible approach to prevention and treatment should be taken into consideration. Scientific evaluation of treatment strategies as presented in this thesis is one step in this process. This will lead to more evidence-based treatment strategies that can be applied in practice.

\section{Target groups}

As mentioned above, the prevalence of overweight and obesity is alarming. Therefore, the target group that could benefit from effective treatment strategies is very large. Direct benefits from treatment are weight loss and improvement of mental and physical well-being. This would result in less health-related costs, and therefore a reduction of the economic burden of obesity and its co-morbid conditions.

The insights in treatment strategies that result in significant weight loss and improvements in mental and physical well-being can help health care professionals to introduce more effective treatment programmes. These treatment programmes could be further 
adapted to specific patient characteristics, and to patient groups suffering from various (multiple) co-morbid conditions, like type 2 diabetes or cardiovascular disease.

Health care insurance companies are always searching for more efficient and effective treatment for all kinds of diseases. The multifactorial aspect of obesity with the risk of developing numerous co-morbid conditions makes obesity a potential high cost condition. Insight in evidence based treatment strategies that reduce (the risk of) these comorbid conditions can be very valuable for insurance companies. Such information can help to choose the right treatment for a patient, so that there is no waste of money on treatments that do not produce the results needed.

\section{Activities}

Societal implementation of scientific research results can take several years. However, in the case of scientific research on the topic of obesity treatment, which is a hot topic nowadays, such results may be implemented at a quicker pace. That is exactly the case for some results presented in this thesis. Implementations related to the results in this thesis will be discussed below in order of appearance.

The study presented in chapter $\mathbf{3}$ is a part of the large scale DIOGENES multicentre trial. DIOGENES was a pan-European programme targeting the obesity problem from a dietary perspective seeking new insights and new routes to prevention. The results of the DIOGENES trial have been used to publish a book named the World's best diet (Bitz \& Astrup, Verdens bedste kur, Kopenhagen, JP/Politikens Vorlag (2012)). It has been translated in many languages and is being published in several countries including the Netherlands. This book focuses on a high protein and low carbohydrate diet resulting in improved long-term weight loss maintenance. The diet is based on fresh vegetables, lean protein sources like fish, poultry, legumes, nuts and dairy foods and dense, grainy foods like rye bread, pumpernickel and barley. The idea is to change the carbohydrateto-protein ratio in the diet by a modest reduction of fat intake and a modest increase in protein intake, to give a ratio of around 2:1 in favour of carbohydrates. Although the book was published before the paper in chapter 3 was written, the results in chapter 3 underline the importance of increased protein intake as it is explained in this book.

Chapter 4 showed the results of the CO-EUR 18-month multidisciplinary treatment programme. CO-EUR used these results to completely renew their treatment programme. CO-EUR concluded that the largest improvement in physical and mental health is achieved in the first 9 months. Therefore, a shorter programme could be more efficient. So instead of one standardized 18 months programme, CO-EUR now offers 3 individualized modular treatment programmes of 6,12 and 18 months respectively. 
The 18 months variant is only used in extreme cases where severe psychological comorbidities need long-term treatment. Instead of the former standardized 18 months programme, the 3 treatment programmes are now individualized and modular. Every treatment starts with 4 months of their in-house designed Health Improvement Programme (HIP!). This is an innovative, integrative psychotherapy module that is being backed up by dietetics and physical activity In these first four months the treatment team searches for personal goals and obstacles in the clients life. They analyse the underlying pathology, coping strategies and social interaction after which a holistic theory or psychodynamic hypothesis is formulated. On the basis of these aspects the multidisciplinary treatment programme is constructed. After these first 4 months the treatment team can choose out of a number of modules to form an individual treatment programme adapted to the specific needs of the patient. Evaluation of these new programmes would be very interesting, because early recognition of possible flaws can result in further improvement of the treatment programme. A continuous evaluation cycle to compare the data of the different treatment locations of CO-EUR has already been implemented. The data generated by this evaluation cycle was used to show whether the results of the different treatment locations were comparable, and if not, what could be done about it.

The result from our study in chapter 5 that physical activity alone can improve glucose tolerance in severely obese persons can help in understanding the value of physical activity within a multidisciplinary treatment programme. Getting obese patients to become more physically active can be a challenge for health care professionals within a treatment programme. Innovative ehealth products like smartphone apps can aid in showing the amount of physical activity performed on a daily basis and what is eventually needed to improve the patient's physical health. The results on how much physical activity is needed to improve glucose tolerance can be used in such ehealth products. This can improve the understanding of the treatment in relation to the health status of the individual patient.

The genetic predictors of high weight loss as described in chapter 6 could be used in comprehensive prediction models. Although patient specific prediction models are still in their infancy, such models could predict treatment outcome in an early stage of treatment, so that the treatment could be quickly adapted to the patient's specific needs. The complexity of the human body makes it very difficult to predict treatment outcome, and genetic factors are probably not the most important influential factors in this process. Future research has to be performed to gain more knowledge and insight on this subject. 


\section{Innovation}

Together with the increase of people suffering from obesity, scientific research concerning this topic has exploded in the last 30 years. Many new products and diets are brought to the market every year claiming to promote rapid weight loss, often with little to no effort from the obese person. Numerous diets have been developed ranging from eating only certain foods like bananas or apples or diets consisting of high fat/no carbohydrates and vice versa, all claiming to be the one diet that works wonders. The truth to all diets is, is that they all work! It is the adherence to a diet that is the problem. Most of those diets are doomed to fail because it is impossible to adhere to them for a longer period of time. Who would want to eat apples for the rest of their lives? Designing a diet that truly works and that can be adhered to for many years, maybe even a lifetime, is a challenge. Scientist around the globe are continuously researching our diet and dietary habits in search of a solution for the obesity epidemic. In January 2005, the Diet, obesity and genes (DIOGENES) project started. It was an innovative multi-disciplinary, multi-centre research project to advance understanding of how obesity can be prevented and treated from a dietary perspective. It integrated studies of dietary, genetic, physiological and behavioural factors. This five-year programme involved a consortium of 29 partners across Europe. It was made up of world-class centres in diet-and health studies, epidemiology, dietary genomics and food technology. It also included 3 major food industrials and 5 Small- and Medium-Sized Enterprises. It was the first large-scale pan-European dietary intervention study to date.

The CO-EUR treatment centre was founded in 2008. It was one of the few multidisciplinary obesity treatment centres in the Netherlands at that time. Prof. Dr. van Baak and Prof. Dr. Kuipers were asked to help in the scientific evaluation of the CO-EUR treatment programme. This thesis is the product of that evaluation. Three chapters in this thesis are written with data generated from the CO-EUR treatment programme. This thesis is also the first in the Netherlands that evaluates a local commercial obesity treatment programme. It has already been explained that the results of this evaluation have been used to renew the programme, making it more efficient with 3 different treatment programmes.

\section{Planning and realisation}

In this thesis we evaluated conservative treatment strategies for obesity. We gained insight in the value of high protein diets, physical activity and behavioural aspects in the treatment of obesity. Next to these conservative strategies there is also treatment based on medication or surgery. Although we did not review the possibility of combining these treatments within this thesis, it could be an interesting topic for future re- 
search. When surgery would be combined with a pre-treatment as offered within the CO-EUR treatment programme, treatment outcome might be improved further. This would provide a solid base for a large number of treatment seeking obese patients. Being able to offer a broad perspective of treatment options could help in serving the wishes and needs of many obese patients.

As mentioned before, there are several topics from this thesis already implemented in existing products or treatment programmes. There is still a lot of knowledge left in this thesis that could be useful for future studies or implementations in health care solutions. Prediction models that include genetic factors are under development and our data may contribute to their further development. However, such models will still take years to become more accurate, because undoubtedly more factors that influence treatment outcome and their interaction will be discovered. And many of these factors will be patient or population specific. Obesity treatment will keep on evolving and the search for the perfect treatment will probably never stop. 
Dankwoord 


\section{Dankwoord}

Eindelijk is het dan zo ver, mijn proefschrift is af! Uiteraard wil ik heel graag iedereen die op de een of andere manier een bijdrage aan dit boekje heeft geleverd van harte bedanken.

Marleen, de eerste stappen van onze samenwerking werden tijdens mijn Master thesis gezet, ook toen al met obesitas als onderwerp. Jou manier van begeleiding, die in mijn geval veel eigen verantwoordelijkheid betekende, heb ik als zeer prettig ervaren. Ik kan me goed voorstellen dat je vaker dan eens hebt gedacht of ik het ooit zou afkrijgen, maar het is uiteindelijk dan toch gelukt. Ik heb ontzag voor jou manier van doorzetten, zoals bij het diogenes paper waar we 3 jaar over hebben gedaan... ik was er al een tijdje klaar mee. Je bent inmiddels met pensioen en ik hoop dat je samen met Bart heel veel kunt genieten van je vrije tijd. Het is je gegund.

Harm, vanwege de grote tegenslagen waarmee je te maken hebt gehad, hebben we niet heel veel contact gehad de afgelopen jaren, maar als ik vragen had kon ik altijd rekenen op een snelle en duidelijke reactie. Ik waardeer het enorm, dat nu het weer beter met je gaat, je je activiteiten als promotor weer voortzet. Ik wens je heel veel gezondheid voor de komende jaren toe.

Leden van de beoordelingscommissie, bedankt voor het kritisch lezen van mijn proefschrift en de deelname aan mijn promotieplechtigheid.

Mijn paranimfen, Maarten en Sebastian. Maarten, mosseltje, je kwam net na mij bij die gekke Kingma in 2.318 terecht en wat hebben we een lol gehad. HCK, balletje balletje we hebben te veel meegemaakt om op te noemen. Met jou zijn die 4 jaar in Maastricht omgevlogen en ik had het voor geen goud willen missen. 2.318 staat voor altijd in mijn geheugen gegrift. Sebastian, als mijn enige (en oudere) broer sta je al sinds mijn geboorte aan mijn zijde. Je was getuige toen ik trouwde, je bent de peetoom van Emilia, dus het is vanzelfsprekend dat je ook nu weer naast me staat. We hebben al aardig wat (outdoor) avonturen op onze kerfstok en er zullen er nog veel meer volgen. We zijn twee handen op een buik en ik ben heel erg blij dat jij mijn broer bent.

Boris, officieel mijn langste kamergenoot in 2.318. Toen ik bij je kwam zitten dacht ik nog dat je veel te serieus was, maar gelukkig was daar na de eerste week al geen sprake meer van. Je hebt veel 'interessante' ideeën gehad en we hebben hard en veel gelachen maar jij was ook degene die de serieuze noot terug bracht als er toch echt weer gewerkt moest worden. Zonder jou had ik er vast wel langer over gedaan. 
Guy, je kwam, zag en overwon. Als laatste gekomen en als eerste weer weg, je haalde ons allemaal in. Wellicht omdat jij juist niet in 2.318 zat. Jou harde werken en doorzettingsvermogen heeft me altijd versteld doen staan. Ga zo door hoef ik niet te zeggen, dat doe je vanzelf wel.

Bram en Masper, ook al hebben de vlaggen van jullie thuislanden dezelfde kleuren, jullie zijn totaal verschillend. Desalniettemin mag ik jullie allebei erg graag en ben ik blij dat ik jullie heb leren kennen.

Maartje, Marjet, Anouk, Christel, Evie, Lisje, Hannah, Mark, de dames en heer die als buren van 2.318 de revue zijn gepasseerd. Jullie hebben veel moeten verduren en met name geluidsoverlast, maar ik waardeer het enorm dat jullie de verdraagzaamheid zelve waren. Betere buren kon ik me niet wensen. Jullie deur stond altijd open en er was ook meestal wel wat te eten.

De stagiaires die me voor kortere of langere tijd fantastisch hebben geholpen. Yvonne, Marcia, Reni, Marlot, Maud, Harry, Rainer, Stefan, Rens, allemaal ontzettend bedankt voor jullie inzet en hulp.

Uiteraard mag ik de engeltjes van het secretariaat niet vergeten, de administratieve ruggengraat van de afdeling en altijd in voor een praatje. De collega's van HB en BW waar ik al dan niet mee heb samengewerkt. Freek zonder jou hulp was er van die buffy coats nooit wat terecht gekomen. Edwin, bedankt voor je hulp bij het snp artikel. Dorit, van Health and Sports ben je me achtervolgd naar Maastricht. We hebben een gezellige tijd gehad en ik hoop dat je je proefschrift snel kunt afronden. Laten we elkaar vooral niet uit het oog verliezen.

Mijn collega's van CO-EUR. Het secretariaat voor het helpen met versturen van proefpersoon informatie en het invullen van de vragenlijsten. Afdeling somatiek voor de bloedafnames en het gehannes met de usb-sticks. En alle andere collega's die hun steentje hebben bijgedragen. Zonder CO-EUR was dit proefschrift er nooit geweest.

Wetenschappelijk onderzoek kan niet worden uitgevoerd zonder proefpersonen. Het merendeel van mijn proefpersonen was afkomstig van CO-EUR. Mijn hartelijk dank voor eenieders deelname.

Mam, jij en pap hebben me altijd de mogelijkheid gegeven om dat te doen wat ik graag wilde. Jullie hebben me gemotiveerd om net iets hoger in te zetten, omdat jullie ervan overtuigd waren dat ik het toch wel kon. Jullie staan aan de basis van wat ik ben geworden, zonder jullie opvoeding en volharding had ik dit nooit gehaald. Het afgelopen 
jaar, de eindspurt van mijn proefschrift, was zonder jou hulp nooit gelukt. Lieve mam, bedankt dat je er altijd voor me bent.

Pap, we hebben allebei een hekel aan voetbal, maar ik ben aan de bal gebleven. Alweer heb ik er wat langer over gedaan, maar toch heb ik het gehaald. Het is zo jammer dat je te vroeg bent gegaan want ik weet dat je apetrots zou zijn geweest. Je bent voor altijd bij me.

Emilia, mijn lieve kleine meid. Dat zo een klein meisje, zo een grote betekenis voor me kan zijn had ik nooit verwacht. Ik heb vanaf nu alle tijd om met jou bezig te zijn en dat zal ik met heel mijn hart doen. De wereld ligt nog aan je voeten en we gaan er wat moois van maken.

Anna, meine große Liebe. Als du mit deiner Doktorarbeit angefangen hast, hab ich gedacht: „Naja, das schaffe ich auch“; also warum nicht? Du bist also eigentlich der Grund dafür, dass ich das Ganze angefangen habe und auch der Grund dafür, dass das es jetzt ein Ende hat. Ohne deine Motivation und Unterstützung und die Tage, an denen du mir den Rücken freigehalten hast, hätte ich es nicht geschafft. Erst jetzt weiß ich, wie mühsam es für dich war- und dabei warst du auch noch viel schneller fertig ;-) Mein Baby, es war nicht immer einfach mit mir, aber zusammen haben wir es geschafft. Wir haben eine wunderschöne kleine Herde und ich bin mir sicher, dass die Zukunft ein Traum wird. Ich werde dich für immer lieben.

En dan zijn er vast nog wel mensen die hadden verwacht dat ik ze persoonlijk zou vermelden, maar helaas. Ik wil er geen ellenlang verhaal van maken. Mocht ik je persoonlijk zijn vergeten, dan alsnog bedankt! 
Curriculum Vitae 


\section{Curriculum vitae}

Erik Aller was born on the $24^{\text {th }}$ of December 1982 in Sittard, the Netherlands. He attended secondary school at Trevianum in Sittard. In 2008 he received his Bachelor degree in Physiotherapy from Hogeschool Zuyd in Heerlen and continued with the European master of Metabolism and Nutrition at Maastricht University. After graduating in 2009 he started a PhD under the supervision of Prof. Dr. M. A. van Baak and Prof. Dr. H. Kuipers at the department of Human Biology at Maastricht University. During his PhD he focused on obesity treatment and studied conservative treatment strategies for obesity as demonstrated in the present dissertation and the numerous publications in scientific journals. In 2013 he started working for CO-EUR as a consultant research and innovation. 


\section{List of publications}




\section{Published manuscripts}

Aller EE, Abete I, Astrup A, Martinez JA, van Baak MA. Starches, sugars and obesity. Nutrients. 2011 Mar;3(3):341-69

Aller EEJG, van Baak MA. Physical activity improves glucose tolerance independent of weight loss in severe obesity. J Diabetes Metab. 2013 Mar;4:254

Mariman EC, Bouwman FG, Aller EE, van Baak MA, Wang P. High frequency of rare variants with a moderate-to-high predicted biological effect in protocadherin genes of extremely obese. Genes Nutr. 2014 May;9(3):399

Aller EE, Larsen TM, Claus H, Lindroos AK, Kafatos A, Pfeiffer A, Martinez JA, HandjievaDarlenska T, Kunesova M, Stender S, Saris WH, Astrup A, van Baak MA. Weight loss maintenance in overweight subjects on ad libitum diets with high or low protein content and glycemic index: the DIOGENES trial 12-month results. Int J Obes (Lond). 2014 Dec;38(12):1511-7

Mariman EC, Bouwman FG, Aller EE, van Baak MA, Wang P. Extreme obesity is associated with variation in genes related to the circadian rhythm of food intake and hypothalamic signaling. Physil Genomics. 2015 Jun;47(6):225-31

Mariman EC, Szklarczyk R, Bouwman FG, Aller EE, van Baak MA, Wang P. Olfactory receptor gene cooperate with protocadherin genes in human extreme obesity. Genes Nutr. 2015 Jul;10(4):465

\section{Submitted manuscripts}

Aller EEJG, van Baak MA. Evaluation of an 18 months commercial multidisciplinary obesity treatment programme. Submitted

Aller EEJG, Mariman ECM, Bouwman FG, van Baak MA. Genetic predictors for high weight loss by multidisciplinary advice to severely obese subjects in real-life circumstances. Submitted 


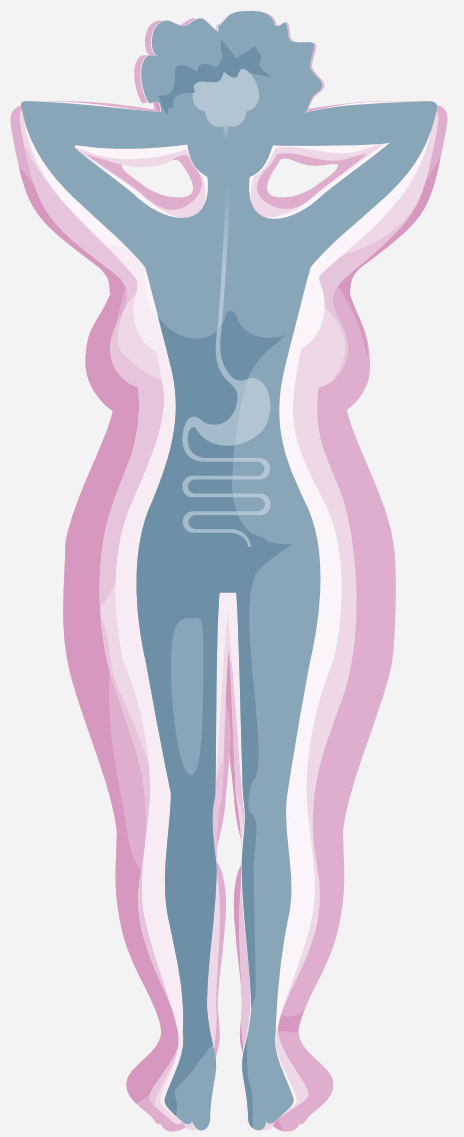

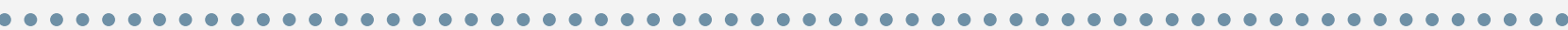

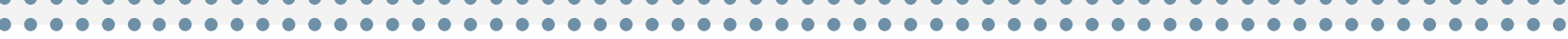

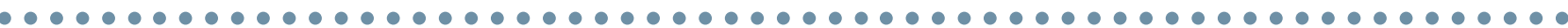

